José Augusto Moreira de Carvalho

\title{
O FEDERALISMO FISCAL BRASILEIRO E O DESVIO DE RECURSOS
}

\author{
Tese apresentada à Faculdade de Direito da \\ Universidade de São Paulo (Departamento de \\ Direito Econômico e Financeiro), como \\ exigência parcial para obtenção do título de \\ Doutor em Direito.
}

Orientador: Professor Titular Regis Fernandes de Oliveira.

\section{UNIVERSIDADE DE SÃO PAULO \\ FACULDADE DE DIREITO}

São Paulo 
Ao meu querido filho, brilho da minha vida.

À minha querida mulher, companheira inseparável e colaboradora em todos os momentos. Aos meus amados pais, exemplos de amor e virtude. Às minhas irmãs, amigas de todas as horas. 


\section{AGRADECIMENTOS}

Ao Doutor Regis Fernandes de Oliveira, parlamentar exemplar e, acima de tudo, professor de todos que militam no Direito Financeiro. Sua sabedoria e paciência se destacaram durante todo o processo de orientação.

Ao Doutor Estevão Horvath, que no exame de qualificação forneceu ensinamentos sólidos para o aprimoramento deste trabalho. Ao Doutor José Mauricio Conti, que não apenas na qualificação, mas durante todo o período do curso me forneceu subsídios importantes para a elaboração e definição do presente estudo.

À Nanci e ao Senhor Cid Ragaini, colaboradores e incentivadores em todos os momentos.

Ao Doutor Joaquim Portes de Cerqueira César, que sempre me apoiou na busca do conhecimento e me incentivou a estudar continuamente.

Às Doutoras Raquel Perez Antunes Chust, Leonídia Sebastiani Meccheri e Márcia Rocco de Castilho, valiosas companheiras de trabalho, que se sacrificaram durante os meus períodos de ausência e sem as quais a conclusão do trabalho não seria possível.

Aos meus colegas de trabalho, Doutores Clodomiro Fernandes Lacerda, Graziella Ambrosio, Mariana Moraes de Araújo e Mércia Clemente, bem como a todos os advogados de suas equipes, profissionais dedicados e valorosos.

Aos Doutores Edison Magnani, Edinei Silva Teixeira e Carlos Eduardo Goettenauer, bem como às bibliotecárias Antonieta e Semiramis, pela ajuda na busca de subsídios para este trabalho.

Ao prezado amigo Ovídio Poli Junior, pela ajuda nos momentos finais e decisivos.

À Universidade de São Paulo, pela oportunidade de realização do curso de doutorado. 
Todo governo que não age na base do princípio da república, isto é, que não faz da res publica o seu objetivo completo e único, não é um governo bom.

Thomas Paine (1737-1809), Os Direitos do Homem Governarei de acordo com o bem geral, não de acordo com a vontade geral.

Jaime I, Rei da Inglaterra e da Irlanda (1603-1625) 


\section{RESUMO}

A concepção tradicional de federação remete à possibilidade de uma melhor organização do Estado, proporcionando-lhe maior desempenho na execução da atividade financeira para satisfazer as necessidades públicas em níveis mais eficientes. As estruturas federativas existentes no mundo, porém, apresentam diferenças entre si e vários são os elementos que contribuem para essa ocorrência, motivo pelo qual não se pode conceber um modelo único de federação, imune a deficiências e problemas. Um Estado federado, dependendo do padrão de federação que adote (mais descentralizado ou menos descentralizado, por exemplo), pode não ser capaz de solucionar questões de vital interesse à sociedade. Na presente tese de doutorado, o autor analisa as características da federação brasileira e procura perscrutar se existe relação entre a estrutura do federalismo fiscal adotada no Brasil e a ocorrência de desvios de recursos públicos, dentre os quais os deflagrados por atos de corrupção. A preocupação contida no estudo não é apenas a de investigar essa relação, mas a de avaliar suas possíveis causas, analisando de forma criteriosa os níveis de descentralização presentes na federação e o grau de autonomia dos entes federados. No primeiro capítulo são discutidos o conceito, características e classificação dos Estados federais, a importância da federação para a atividade financeira estatal, os princípios do federalismo fiscal e as funções fiscais alocativa, distributiva e estabilizadora. A investigação sobre a possibilidade da existência de vínculo entre o desvio de recursos e o tipo de estrutura do federalismo fiscal é objeto de análise no segundo capítulo, no qual também serão expostas definições e características de condutas que tendem a provocar o mencionado transviamento, tais como o rent-seeking (comportamento caçador de renda), o patrimonialismo, o clientelismo, o coronelismo e a corrupção. O terceiro capítulo cuida da análise do arcabouço do federalismo fiscal brasileiro e procura examinar se os níveis de descentralização presentes no país são adequados para uma perfeita relação entre os entes subnacionais e o governo central, bem como se essa estrutura impede ou estimula as ocorrências de desvios de recursos públicos. No quarto capítulo, as hipóteses contidas nos capítulos anteriores são demonstradas por meio da análise do processo orçamentário federal (mais especificamente em relação às consequências advindas da elaboração da lei orçamentária anual) e das transferências intergovernamentais no Brasil.

Palavras-chave: Federação - Federalismo fiscal - Desvio de recursos públicos - Corrupção Rent-seeking - Clientelismo - Patrimonialismo - Coronelismo - Descentralização - Autonomia - Orçamento - Transferência intergovernamental. 


\begin{abstract}
The traditional conception of a federation leads us to the possibility of a better organized Government, capable of satisfactorily performing the financial activity in order to meet the public needs at more efficient levels. However, the federative structures existing worldwide today are quite different from each other and various are the elements contributing to such occurrence - and this is why we cannot conceive one single federation model unaffected by deficiencies and problems. A federate Union, depending on the federation model adopted thereby (either a more or less decentralized one, for instance), may be unable to solve issues of vital interest to the society as a whole. In this dissertation, the author analyzes the characteristics of the Brazilian federation and seeks to scrutinize whether there is a relation between the fiscal federalism structure adopted in Brazil and the occurrence of deviation of public funds, including those triggered by corruption acts. Rather than simply investigating such relation, this dissertation is concerned with evaluating the possible causes for deviation of public funds, minutely examining the levels of decentralization present in the federation and the degree of autonomy among the federated entities. In chapter one, the author discusses the concept, characteristics and classification of the federal states, the importance of the federation for the financial activity performed by the Government, the principles of fiscal federalism and the allocable, distributive and stabilizing fiscal functions. Whether there is a connection between the deviation of funds and the type of structure of fiscal federalism is investigated in chapter two, where definitions and characteristics of conducts prone to cause the mentioned deviation are expounded by the author, such as rent-seeking, patrimonialism, clientelism, coronelismo and corruption. In chapter three, the author analyzes the framework of Brazilian fiscal federalism and examines whether the levels of decentralization existing in Brazil are proper for a perfect relation between the subnational entities and the central Government, as well as whether such structure either impedes or otherwise fosters the occurrences of public fund deviation. Chapter three demonstrates the hypotheses contained in the previous chapters by means of an analysis of the federal budgetary process (more specifically in relation to the consequences derived from preparation of the annual budgetary law) and intergovernmental transfers in Brazil.
\end{abstract}

Keywords: Federation - Fiscal federalism - Deviation of public funds - Corruption - Rentseeking - Clientelism - Patrimonialism - Coronelismo - Decentralization - Autonomy - Budget - Intergovernmental transfer. 


\section{RIASSUNTO}

La concezione tradizionale di federazione rimette alla possibilità di una miglior organizzazione dello Stato, fornendogli una performance più grande nell'esecuzione dell'attività finanziaria per soddisfare le necessità pubbliche a livelli più efficienti. Le strutture federative esistenti nel mondo, però, presentano differenze tra loro e sono vari gli elementi che contribuiscono a questo, ragione per cui non si può concepire un modello unico di federazione immune a deficienze e problemi. Uno Stato federato, dipendendo dal modello di federazione che adotti (più decentrato o meno decentrato, ad esempio) può non essere capace di risolvere questioni d'interesse vitale per la società. Nella presente tesi di dottorato, l'autore analizza le caratteristiche della federazione brasiliana e cerca di indagare se esista o meno un rapporto tra la struttura del federalismo fiscale adottata in Brasile e l'avvenimento di sottrazioni di risorse pubbliche, tra le quali quelle scopiate da atti di corruzione. La preoccupazione presente in questo studio non è soltanto quella di investigare questo rapporto, ma quella di valutarne le possibili cause, analizzando in modo assennato i livelli di decentramento presenti nella federazione ed il grado di autonomia degli enti federati. Nel primo capitolo sono discussi il concetto, le caratteristiche e la classificazione degli Stati federali, l'importanza della federazione per l'attività finanziaria statale, i principi del federalismo fiscale e le funzioni fiscali allocativa, distributiva e stabilizzatrice. L'investigazione sulla possibilità dell'esistenza di un legame tra la sottrazione di risorse e il tipo di struttura del federalismo fiscale è oggetto di analisi nel secondo capitolo, in cui sono esposte anche delle definizioni e caratteristiche di condotte che tendono a suscitare pratiche, tali come il rent-seeking (comportamento cacciatore di rendita), il "patrimonialismo", il clientelismo, il "colonnellismo" e la corruzione. Il terzo capitolo si occupa dell'analisi della struttura del federalismo fiscale brasiliano e cerca di esaminare se i livelli di decentramento presenti in Brasile siano adeguati ad un perfetto rapporto tra gli enti sottonazionali ed il governo centrale, come anche se questa struttura impedisca o stimoli le pratiche di sottrazioni di risorse pubbliche. Nel quarto capitolo le ipotesi presentate nei capitoli precedenti sono dimostrate attraverso un'analisi del processo budgetario federale (più specificamente per quanto riguarda le conseguenze derivanti dall'elaborazione della legge budgetaria annuale) e dei trasferimenti di risorse tra i governi federale, degli stati e municipali in Brasile.

Parole chiave: Federazione - Federalismo fiscale - Sottrazione di risorse pubbliche - Corruzione Rent-seeking - Clientelismo - "Patrimonialismo" - "Colonnellismo" - Decentramento Autonomia - Budget - Trasferimento di risorse tra i governi federale, degli stati e municipali. 


\section{SUMÁRIO}

INTRODUÇÃO.

1. O FEDERALISMO FISCAL ......................................................................... 14

1.1 Definição de Estado............................................................................... 14

1.2 Centralização e descentralização estatal......................................................... 16

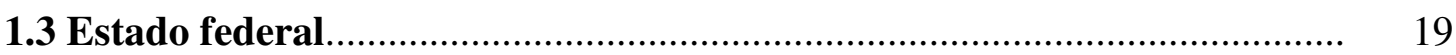

1.3.1 Principais elementos do Estado federal.................................................. 21

1.3.2 Classificação dos Estados federais.......................................................... 23

1.4 A federação e a atividade financeira do Estado............................................ 25

1.5 Federalismo fiscal................................................................................... 27

1.6 Princípios do federalismo fiscal e o exercício das funções fiscais................. 29

1.6.1 Princípio do benefício e a função fiscal alocativa................................... 31

1.6.2 Princípio da distribuição centralizada e as funções fiscais distributiva e estabilizadora.............................................................................. 35

1.6.3 Princípio da compensação fiscal........................................................ 41

2. O DESVIO DE RECURSOS E SUA RELAÇÃO COM O FEDERALISMO FISCAL.

2.1 O difícil ajuste entre as funções fiscais no âmbito do federalismo e o problema do desvio de recursos públicos....................................................... 46

2.2 A conduta rent-seeking ou captação do Estado............................................ 50

2.3 Patrimonialismo, clientelismo e coronelismo ……………………………..... 53

2.3.1 Origem do patrimonialismo e seu significado atual................................ $\quad 54$

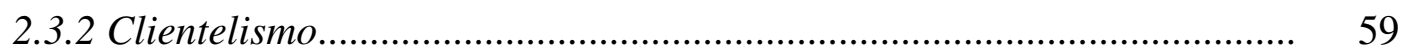

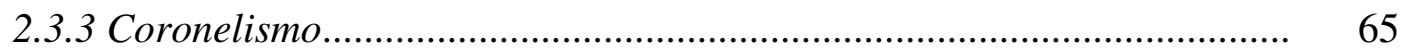

2.4 Corrupção

2.4.1 Conceito de corrupção................................................................... 68

2.4.2 A corrupção como risco à República ................................................... 75

2.4.3 A corrupção e a democracia.................................................................. 77

2.4.4 A corrupção, o desenvolvimento econômico e social, a ética e o papel do Estado .................................................................................. 78

2.5 Há relação entre o desvio de recursos públicos e o federalismo fiscal?...... 86 
2.5.1 O desvio de recursos públicos e suas consequências para as funções fiscais.

2.5.2 O desvio de recursos públicos e sua relação com o tipo de estrutura do federalismo fiscal.

\section{O ARCABOUÇO DO FEDERALISMO FISCAL BRASILEIRO E OS} INCENTIVOS AO DESVIO DE RECURSOS PÚBLICOS.....

3.1 A federação brasileira e a concentração de poder no governo central...............

3.2 A repartição de competências, o nível de descentralização fiscal e de políticas previstas na Constituição Federal, o problema da rigidez orçamentária e a frágil autonomia dos entes subnacionais.....

3.3 O controle do endividamento dos entes subnacionais e ainda a questão

da autonomia.

3.4 A assimetria da federação brasileira e a descentralização política

3.5 A competência vertical no federalismo fiscal brasileiro e a autoridade compartilhada na elaboração de políticas.

3.6 A competição horizontal no federalismo fiscal brasileiro.

3.6.1 A dificuldade em estabelecer a competição horizontal entre os municípios brasileiros...

3.6.2 A competição horizontal entre os estados e a questão da guerra fiscal..

3.7 A necessidade de se repensar a federação e o federalismo fiscal brasileiros.

3.7.1 A ausência de equilíbrio nas dimensões da descentralização brasileira.

3.7.2 O importante papel das instituições no federalismo fiscal brasileiro e a questão da accountability $e$ do controle.

\section{O ORÇAMENTO, AS TRANSFERÊNCIAS INTERGOVERNAMENTAIS}

E O DESVIO DE RECURSOS NO BRASIL

4.1 A ausência de autonomia dos entes subnacionais e a perene dependência em busca de rendas.

4.2 O papel do orçamento

4.3 As peças orçamentárias no ordenamento jurídico brasileiro. 
4.4 O procedimento de elaboração da lei orçamentária anual..

4.4.1 A elaboração da proposta da lei orçamentária anual........................... 169

4.4.2 A aprovação da lei orçamentária anual............................................... 172

4.5 Os poderes conferidos ao Congresso Nacional na questão orçamentária e as circunstâncias incentivadoras ao desvio de recursos públicos

4.5.1 A apresentação de emendas à proposta da lei orçamentária anual, o pork-barrel e a impossibilidade de se alcançar o interesse nacional......

4.5.2 As emendas ao orçamento e a relação dos parlamentares com suas bases eleitorais.

4.5.3 A prática do lobby no processo de emendas ao orçamento e o interesse das empreiteiras.

4.5.4 O poder em mãos do governo central: a troca de favores e a liberação de verbas objeto das emendas.

4.6 As transferências intergovernamentais.

4.6.1 A utilização das transferências intergovernamentais como forma de proporcionar a equalização fiscal.

4.6.2 Classificação das transferências intergovernamentais...... 201

4.6.3 Os fundos de participação: conceito, características e espécies.

4.6.4 Os critérios de apuração e repartição do Fundo de Participação dos Estados e do Distrito Federal (FPE) e do Fundo de Participação dos Municipios (FPM). 206

4.6.5 Os fundos de participação e o desvio de recursos públicos no país. 209

4.6.6 As transferências voluntárias e o desvio de recursos públicos. 216 


\section{INTRODUÇÃO}

A maioria dos doutrinadores que estudam a federação propugnam que ela é uma forma adequada de o Estado se estruturar, pois suas características fornecem condições favoráveis ao atendimento das necessidades públicas. O fator que contribuiria para esse desiderato, dentre outros, seria a presença de níveis governamentais diferentes para atender diversificadas necessidades da população, além do fato de que a existência de estruturas descentralizadas seria capaz de proporcionar maior participação política dos cidadãos na definição de prioridades e nas decisões dos governos locais e regionais. Tais características estimulariam, ainda, a transparência, um melhor nível de fiscalização, o fortalecimento das instituições e o desenvolvimento da democracia.

Ocorre que, na prática, não se tem verificado que o sistema federalista seja capaz de alcançar todos os objetivos mencionados. Aliás, Estados que adotam essa estrutura apresentam níveis de sucesso bastante diferentes uns dos outros.

Parte da explicação para esse fenômeno está na constatação de que não se consegue conceber um modelo único de federação, imune a deficiências e problemas. Dependendo do padrão de federação adotado (mais descentralizado ou menos descentralizado, por exemplo), bem como da forma como o federalismo fiscal é estruturado no seio do Estado, este pode não ser capaz de solucionar questões de vital interesse à sociedade.

Dentre as questões que causam preocupação no âmbito da federação, o desvio de recursos públicos é uma das que merecem maior atenção, tendo em vista os efeitos nefastos que causa para a sociedade e para a própria manutenção da estrutura estatal. Esses desvios, principalmente os originados de atos de corrupção, representam verdadeiro empecilho para o progresso dos países, pois inibem a quantidade de investimentos, incentivam a informalidade, provocam a evasão de divisas, diminuem a margem de lucro das empresas e reduzem a quantidade de recursos públicos.

No caso do Brasil, a manutenção de situações como as relatadas representa enormes riscos, pois além de implicar a redução de serviços públicos voltados à população e necessários ao crescimento econômico, faz com que os cidadãos adquiram um sentimento de descrédito em relação às instituições, principalmente aquelas encarregadas de fiscalizar e impedir atos de desvio de recursos. Cria-se, com isso, um círculo vicioso, desembocando no 
aumento de práticas ainda mais deletérias ao Estado. Verifica-se que não somente a sociedade é atingida, mas a legitimidade do próprio governo é colocada em perigo.

Fato curioso, contudo, é a existência de poucos estudos estabelecendo a relação entre federalismo e desvio de recursos públicos. Da mesma forma, se é verdade que a questão do federalismo fiscal é tema bastante debatido e estudado no ramo do Direito Financeiro, não menos verdade é que sua abordagem em relação ao desencaminhamento de recursos e, principalmente, sobre a corrupção, não vem sendo objeto de análise por parte daqueles que se preocupam com o tema.

A escassez de estudos também reside na investigação da ocorrência desses desvios no âmbito dos entes da federação. Não obstante a existência de diversos dados a respeito do assunto, principalmente em órgãos governamentais como a Controladoria-Geral da União, o Tribunal de Contas da União e os Ministérios Públicos estaduais e federal, o fato é que não existe uma averiguação no campo da Ciência do Direito, mais especificamente do Direito Financeiro, a respeito das causas, dos fatores de influência e dos reflexos do desvio de recursos no âmbito dos municípios, estados e União.

Vale dizer, embora existam trabalhos orientados ao exercício do controle, da fiscalização e da verificação do correto direcionamento dos recursos públicos, não há, no Direito Financeiro, tratamento da questão no tocante às bases do federalismo brasileiro, principalmente sob o aspecto fiscal.

O intuito do presente estudo é justamente o de perscrutar se existe relação entre a estrutura do federalismo fiscal adotada no Brasil e a ocorrência de desvios de recursos públicos, dentre os quais os deflagrados por atos de corrupção. A preocupação não é a de apenas investigar a real presença dessa relação, mas a de avaliar suas possíveis causas, analisando de forma criteriosa os níveis de descentralização presentes na federação e o grau de autonomia dos entes federados.

Para esse fim, buscar-se-á, no primeiro capítulo, discutir o conceito, características e classificação dos Estados federais, a importância da federação para a atividade financeira estatal, os princípios do federalismo fiscal e as funções fiscais alocativa, distributiva e estabilizadora.

A investigação sobre a possibilidade da existência de vínculo entre o desvio de recursos e o tipo de estrutura do federalismo fiscal será feita no segundo capítulo, no qual também serão expostas definições e características de condutas que tendem a provocar o 
mencionado transviamento, tais como o rent-seeking (ou captação do Estado), o patrimonialismo, o clientelismo, o coronelismo e a corrupção.

O terceiro capítulo cuidará da análise do arcabouço do federalismo fiscal brasileiro e procurará examinar se os níveis de descentralização presentes no país são adequados para uma perfeita relação entre os entes subnacionais e o governo central, bem como se essa estrutura impede ou estimula as ocorrências de desvios de recursos públicos.

As hipóteses contidas nos capítulos anteriores também serão demonstradas por meio da análise dos aspectos que envolvem o processo orçamentário federal (mais especificamente em relação às consequências advindas da elaboração e aprovação da lei orçamentária anual) e as transferências intergovernamentais originadas dos fundos de participação e das transferências voluntárias.

Por fim, com o intuito de delimitar e firmar os principais pontos do estudo, uma breve conclusão será exposta ao final. 


\section{Capítulo 1}

\section{O FEDERALISMO FISCAL}

1.1 Definição de Estado - 1.2 Centralização e descentralização estatal - 1.3 Estado federal: 1.3.1 Principais elementos do Estado federal; 1.3.2 Classificação dos Estados federais - 1.4 A Federação e a atividade financeira do Estado - 1.5 Federalismo fiscal - 1.6 Princípios do federalismo fiscal e o exercício das funções fiscais: 1.6.1 Princípio do benefício e a função fiscal alocativa; 1.6.2 Princípio da distribuição centralizada e as funções fiscais distributiva e estabilizadora; 1.6.3 Princípio da compensação fiscal.

\subsection{Definição de Estado}

É entendimento uniforme na doutrina que a existência do Estado é subordinada à presença de certos elementos caracterizadores. A quantidade e características desses fatores, porém, não encontram regularidade para os teóricos sobre o assunto. Apesar da divergência existente, é possível indicar os quatro elementos recorrentes, os quais permitirão o esboço de uma definição de Estado. São eles: povo, território, soberania e finalidade ${ }^{1}$.

Entende-se por povo todas as pessoas que estão conectadas ao Estado por intermédio da cidadania e que se sujeitam à sua ordem jurídica. O território nada mais é do que a área na qual essa ordem jurídica exerce sua atuação.

\footnotetext{
Dalmo de Abreu Dallari (Elementos de teoria geral do Estado. 24a ed. São Paulo: Saraiva, 2003, p. 72) sustenta a presença dos elementos citados para a caracterização do Estado. Já Paulo Bonavides (Ciência política. 10 a ed. São Paulo: Malheiros, 2004, pp. 66-67) e Celso Ribeiro Bastos (Curso de Teoria do Estado e Ciência Política. $6^{a}$ ed. São Paulo: Celso Bastos Editora, 2004, p. 67) defendem a existência de somente três fundamentos: povo, território e soberania. Outra concepção diversa é a externada por Léon Duguit (Fundamentos do direito. Tradução de Ricardo Rodrigues Gama. Campinas: LZN Editora, 2003, p. 48. Título original: Fondements de droit), que sustenta: "Em resumo: a nossa construção jurídica do Estado acompanha os fatos de tão perto quanto possível. Rejeitando os conceitos metafísicos de pessoa coletiva e soberania, compõe-se de seis elementos de ordem puramente positiva: $1^{\circ}$ ) uma coletividade social determinada; $2^{\circ}$ ) uma diferenciação nesta coletividade entre governantes e governados, sendo aqueles governantes só pelo fato de que possuem maior força; $3^{\circ}$ ) a sua obrigação jurídica de assegurar a realização do direito; $4^{\circ}$ ) a obediência devida a toda regra geral, formulada pelos governantes, para verificar ou aplicar a regra do direito; $5^{\circ}$ ) o emprego legítimo da força, para sancionar todos os atos conformes com o direito; $6^{\circ}$ ) o caráter próprio de todas as instituições que tendem a assegurar o cumprimento da missão obrigatória dos governos ou serviços públicos”.
} 
Já a soberania representa o poder exercido pelo Estado em relação ao seu povo e no trato com os demais Estados. Reconhece-se que um Estado é soberano quando não há domínio sobre ele de nenhum outro poder, seja no âmbito interno, seja no externo ${ }^{2}$.

A finalidade significa os objetivos traçados pelo Estado, fins esses consubstanciados na perseguição do bem comum de seu povo ${ }^{3}$.

Com base nos fundamentos acima traçados, é possível adotar a definição de Dalmo de Abreu Dallari ${ }^{4}$, para quem o Estado significa uma "ordem jurídica soberana que tem por fim o bem comum de um povo situado em determinado território". É possível, assim, caracterizar o Estado como uma sociedade que possui organização jurídica, que se encontra estabelecido em território definido e cujo poder encontra-se direcionado à regulação das relações internas e externas, com o objetivo último (finalidade) de realizar o bem comum do povo.

Importante lembrar que a concepção moderna de Estado não prescinde que ele possua um aparelhamento de ordem administrativa, regulado pelo direito e destinado à execução de serviços públicos para bem cumprir sua finalidade ${ }^{5}$.

2 Segundo a definição de Celso Ribeiro Bastos (Curso de Teoria do Estado e Ciência Política. $6^{a}$ ed. São Paulo: Celso Bastos Editora, 2004, p. 94), "a soberania é, pois, um atributo do Estado. Traduz-se a soberania pela circunstância de não reconhecer nenhum outro poder superior nem igual ao seu na ordem interna nem outro superior na externa".

3 O conceito de bem comum é bem explicitado na Encíclica Mater et Magistra, do Papa João XXIII: "79. No que diz respeito às exigências do bem comum nacional, é necessário prover emprêgo para o maior número possível de trabalhadores; evitar a criação, no país, mesmo entre os operários, de categorias de privilegiados; manter uma côngrua proporção entre os salários e os preços das utilidades; tornar acessíveis ao maior número possível os bens e os serviços indispensáveis a um nível de vida mais elevado; eliminar ou conter dentro de certos limites as desigualdades existentes entre os diversos setores da economia, isto é, entre a agricultura, a indústria e os serviços; manter o equilíbrio entre o aumento da riqueza e o desenvolvimento dos serviços públicos essenciais; ajustar o mais possível as estruturas de produção ao progresso das ciências e da técnica; finalmente, assegurar que a elevação atual do nível de vida não aproveite apenas a esta geração, mas tenha em vista, igualmente, o bem-estar das gerações de amanhã" (Frei Antonio de Sanctis (org.). Encíclicas e documentos sociais: da "Rerum Novarum" à "Octogésima Adveniens". São Paulo: LTR, 1972, p. 246).

4 Elementos de teoria geral do Estado. 24a ed. São Paulo: Saraiva, 2003, p. 118.

5 São essas características, aliás, que contribuem para a separação dos sentidos antigo e moderno do vocábulo "estado". De acordo com Norberto Bobbio, "sejam quais forem os argumentos pró ou contra a continuidade de uma organização política da sociedade, a questão de saber se o Estado sempre existiu ou se se pode falar de Estado apenas a partir de uma certa época é uma questão cuja solução depende unicamente da definição de Estado da qual se parta: se de uma definição mais ampla ou mais estreita (...) Quem considera como elemento constitutivo do conceito de Estado também um certo aparato administrativo e o cumprimento de certas funções que apenas o Estado moderno desempenha, deverá necessariamente sustentar que a polis grega não é um Estado, que a sociedade feudal não tinha um Estado etc." (Estado, governo, sociedade: para uma teoria geral da política. $10^{\mathrm{a}}$ ed. Tradução de Marco Aurélio Nogueira. São Paulo-Rio de Janeiro: Paz e Terra, 2003, p. 69). 
Aliás, a forma como é utilizado tal aparato guarda estreita relação com a maneira pela qual é exercido o poder pelo Estado. Além disso, o modo como o Estado se organiza e a eficiência dessa organização são cruciais para determinar se conseguirá atingir, a contento, as finalidades que ele próprio elegeu para o alcance do bem comum de seu povo.

Daí a importância de se estudar as consequências da centralização ou descentralização de poder no Estado, bem como as formas de sua organização, a fim de melhor investigar os benefícios e as dificuldades que referidos modelos apresentam.

\subsection{Centralização e descentralização estatal}

Verificou-se acima a importância do poder atribuído ao Estado para ditar sua ordem jurídica no âmbito interno; isso significa que nenhuma outra ordem, dentro do mesmo território, prevalecerá ou se igualará àquela determinada por ele, mesmo porque, ocorrendo o contrário, não se poderia falar em soberania e unidade do poder do Estado $^{6}$.

Não se quer dizer, porém, que a unidade central estatal deve, sozinha, regular e exercer as competências necessárias para atingir seu desiderato. É praticamente impossível que isso ocorra de forma absoluta, sob pena de se inviabilizar a manutenção e o progresso do próprio Estado ${ }^{7}$.

Exige-se, na verdade, a presença de uma ordem normativa homogênea que, de forma sistemática, seja capaz de estabelecer normas de conduta e de competência, ainda que sejam elas ditadas por unidades diversas do governo central. Mesmo que a unidade central não se encarregue de, isoladamente, exercer a regulação, é imprescindível que, em conjunto com as demais instâncias, tal realização se dê de forma harmônica, não gerando contradições no sistema. De qualquer forma, em última análise, é o Estado que exerce a preeminência na

6 Reinhold Zippelius. Teoria geral do Estado. $3^{\mathrm{a}}$ ed. Tradução de Karin Praefke-Aires Coutinho. Lisboa: Fundação Calouste Gulbenkian, 1997, p. 80. Título original: Allgemeine Staatslehre.

7 De acordo com Georg Jellinek (Teoría general del Estado. Tradução de Fernando de Los Ríos. México: Fondo de Cultura Económica, 2000, p. 558. Título original: Allgemeine Staatslehre), o Estado centralista deve assim ser considerado em seu sentido teórico, não real, mesmo porque as autoridades dessas divisões territoriais acabam adotando decisões ainda que fora do âmbito do controle do poder central. No original: "Hemos dicho ya que el Estado centralista, dejando de lado las comunidades políticas inferiors, sólo puede ser considerado como un tipo teórico, pero no como un tipo real. Toda division de un Estado en círculos territoriales para los fines de la gestión administrative y de derecho lleva necesariamente consigo efectos descentralizadores. Las autoridades de estas divisions territoriales no son exclusivamente órganos de ejecución del gobierno central, sino que, en determinadas circunstancias, son un poder de decision que queda fuera de la vigilancia y corrección de las autoridades superiores". 
regulação, determinando a homogeneidade da ordem normativa, evitando que haja discrepâncias no estabelecimento das normas e das competências ${ }^{8}$.

Não obstante essa constatação, dependendo da maneira como predominantemente ocorre a concentração de poder em mãos do governo central, principalmente com vistas a estabelecer a mencionada competência, é possível determinar a existência de centralização ou de descentralização estatal.

Da mesma forma que seria impossível a existência de um Estado totalmente centralizado, situação que inviabilizaria sua administração, o mesmo se dá no tocante à descentralização absoluta, cuja existência retiraria o verdadeiro sentido e a própria concepção de Estado. O que deve ser verificado, então, para definir um Estado como centralizado ou descentralizado é, justamente, a existência de traços determinantes de centralização ou descentralização ${ }^{9}$.

Observando-se essas premissas, tem-se que a centralização estatal ocorre quando apenas um núcleo de governo exerce, de forma predominante, os poderes administrativo, legislativo e político do Estado. Já na descentralização, esses mesmos poderes são deslocados do núcleo central e passam a ser exercidos com maior destaque por outras esferas de governo.

Conforme esclarece Fabio Roversi-Monaco ${ }^{10}$, "temos centralização quando a quantidade de poderes das entidades locais e dos órgãos periféricos é reduzida ao mínimo indispensável, a fim de que possam ser considerados como entidades subjetivas de administração" e "temos, ao contrário, descentralização, quando os órgãos centrais do Estado possuem o mínimo de poder indispensável para desenvolver as próprias atividades”.

$8 \quad$ Reinhold Zippelius. Teoria geral do Estado. $3^{\mathrm{a}}$ ed. Tradução de Karin Praefke-Aires Coutinho. Lisboa: Fundação Calouste Gulbenkian, 1997, pp. 63-64 e 81. Título original: Allgemeine Staatslehre.

9 A respeito dessas circunstâncias, Fabio Roversi-Monaco (Descentralização e centralização. In: BOBBIO, Norberto; MATTEUCCI, Nicola; PASQUINO, Gianfranco. Dicionário de política. $12^{\mathrm{a}}$ ed. Tradução de Carmen C. Varriale et al. Coord. da tradução: João Ferreira. Brasília: Editora Universidade de Brasília, 2002, v. 1, pp. 329-330) bem esclarece: "Se, de um lado, a Descentralização total leva a romper a própria noção de Estado, também de outro, foi detectado o caráter utópico de uma centralização total no Estado moderno, caracterizado por uma grande quantidade e complexidade de finalidades e de funções. Isso significa que todos os ordenamentos jurídicos positivos são parcialmente centralizados e, em parte, descentralizados, isto é, que, considerada a centralização e a Descentralização como dois possíveis valores, não existe um sistema político-administrativo que esteja exclusivamente orientado para a otimização de uma ou de outra. Em conseqüência do entrelaçamento dos dois princípios, mesmo em sistemas limitados da organização de um Estado, a Descentralização e centralização muito dificilmente se encontram em estado puro, mas aparecem como centralização e Descentralização imperfeitas".

10 Descentralização e centralização. In: BOBBIO, Norberto; MATTEUCCI, Nicola; PASQUINO, Gianfranco. Dicionário de política. 12a ed. Tradução de Carmen C. Varriale et al. Coord. da tradução: João Ferreira. Brasília: Editora Universidade de Brasília, 2002, v. 1, p. 330. 
Tendo em vista que o presente estudo analisa exatamente uma das formas de descentralização - o federalismo -, importante indagar os principais motivos que levam um determinado Estado a adotar como seu modelo de organização uma forma descentralizada.

Do ponto de vista fiscal, as razões para se empregar tal padrão podem ser de várias ordens, dentre as quais se destacam a econômica, a cultural, a política, a institucional e a geográfica. Sob a ótica econômica, procura-se especificar qual esfera governamental será a responsável por determinado bem ou serviço público com o intuito de estabelecer um grau ótimo de eficiência na satisfação das necessidades públicas. Partindo-se do aspecto cultural, político e institucional, a descentralização é capaz de proporcionar uma maior participação política dos cidadãos nas decisões governamentais, contribuindo para a transparência e democracia, diminuindo a concentração de poder e fortalecendo as instituições. As razões geográficas para a adoção de um modelo descentralizado partem do pressuposto de que os entes subnacionais é que possuem condições de mais facilmente atender as necessidades oriundas de regiões com vasta extensão territorial, uma vez que os mesmos serviços não seriam realizados de forma eficiente pelo governo central ${ }^{11}$.

Percebe-se, dessa forma, que a descentralização é relevante para proporcionar níveis ótimos de eficiência na alocação de recursos públicos e prestação de serviços destinados à população, permitindo que as dificuldades sejam melhor percebidas pelos governantes, os quais poderão adotar medidas eficazes e adequadas para solucioná-las. Também proporciona que a utilização dos recursos do Estado seja melhor fiscalizada pela população, que passa a ter um papel importante na função de controle da atividade financeira estatal.

Além disso, o modelo descentralizado também apresenta importante papel limitador, uma vez que é capaz de decompor o poder e de direcionar seu exercício a diversos órgãos, reduzindo, assim, as chances de excessos que poderiam levar ao autoritarismo ${ }^{12}$ e reforçando a democracia, por intermédio de maior participação do povo ${ }^{13}$.

11 Fabio Giambiagi e Ana Cláudia Duarte de Além. Finanças públicas. $2^{\mathrm{a}}$ ed. Rio de Janeiro: Elsevier, 2000, pp. 306-307. As vantagens da descentralização do ponto de vista da Federação serão estudadas de forma específica mais adiante, nos itens 1.4 e seguintes, nos quais serão destacadas as contribuições de Richard Abel Musgrave, Wallace E. Oates e Charles M. Tiebout para a teoria do federalismo fiscal.

12 Manoel Gonçalves Ferreira Filho. Curso de direito constitucional. 29a ed. São Paulo: Saraiva, 2002, p. 51.

13 Alexis de Tocqueville (Democracia na América. Tradução de João Miguel Pinto de Albuquerque. São Paulo: Companhia Editora Nacional/Editora da Universidade de São Paulo, 1969, p. 85. Título original: Democracy in America), nesse sentido, ressalta o papel desempenhado pelas autoridades locais no que se refere à manutenção e reforço da democracia: “Acredito que as autoridades locais ou provinciais sejam úteis a tôdas as nações, mas em lugar algum elas me parecem ser mais necessárias do que entre os povos democráticos. Numa aristocracia, a ordem pode ser sempre mantida no meio da liberdade; como os 
Antes de analisar esses aspectos no âmbito do federalismo, necessário abordar, em rápidas linhas, os contornos que o Estado pode apresentar de acordo com o grau de descentralização e as principais características do Estado Federal.

\subsection{Estado federal}

De acordo com os critérios utilizados, a classificação do Estado pode se apresentar das mais diferentes formas. Um desses critérios pode se referir ao grau de descentralização política e administrativa estatal.

Entende-se por descentralização política o nível de existência de ordenamentos jurídicos particulares em relação ao ordenamento geral. Já na centralização política não há que se falar em ordenamentos ou sistemas jurídicos menores; o que persiste é a singularidade do ordenamento geral, apenas ${ }^{14}$.

A descentralização administrativa diz respeito ao grau de distribuição das funções administrativas a instâncias hierárquicas menores, enquanto a centralização administrativa compreende o exercício dessas mesmas funções pelo governo central.

Partindo-se, então, do nível de descentralização política e administrativa, o Estado pode ser: a) unitário; b) unitário descentralizado; c) constitucionalmente descentralizado; d) federal.

O Estado unitário é aquele em que o poder político é exercido única e exclusivamente pelo governo central, ainda que se admita a desconcentração da administração em unidades dependentes da decisão desse poder central.

No Estado unitário descentralizado, o poder central é que decide a forma e o nível de descentralização política a ser exercida pelos membros da organização estatal.

dirigentes têm muito a perder, a ordem para êles é uma questão de grande interêsse. De maneira semelhante, a aristocracia protege o povo dos excessos do despotismo, porque possui sempre um poder organizado pronto para resistir a um déspota. Mas a democracia, sem instituições provinciais, não tem garantia contra êsses males. Como pode a população não acostumada à liberdade em pequenas coisas, usá-la,temperadamente, nas grandes? Que resistência se pode oferecer à tirania num país onde cada indivíduo é fraco e onde os cidadãos não estejam unidos por qualquer interêsse comum? Os que têm pavor da licença da multidão e os que receiam o poder absoluto deveriam desejar, igualmente, o desenvolvimento gradual de liberdades provinciais ou locais".

14 Paulo Bonavides. Ciência política. $10^{\mathrm{a}}$ ed. rev. e atual. São Paulo: Malheiros, 2004, p. 151. 
De modo diverso, o Estado constitucionalmente descentralizado caracteriza-se pelo fato de que seu nível de descentralização não é estabelecido pelo governo central, mas sim pelo Poder Constituinte ${ }^{15}$.

Apesar de o Estado Federal se assemelhar ao Estado constitucionalmente descentralizado, com ele não se confunde, principalmente em razão de apresentar características de invulnerabilidade, já que sua estrutura (definida pelo Poder Constituinte originário) não pode ser suprimida. Consiste, segundo a definição de Celso Ribeiro Bastos, na "forma de Estado pela qual se objetiva distribuir o poder, preservando a autonomia dos entes políticos que a compõem"16.

Em outras palavras, representa uma forma de o Estado se estruturar, de maneira que cada ente que o integra possa exercer sua autonomia (ainda que relativa) e participar da formulação da vontade geral da Federação. Os entes que formam a Federação são chamados de Estados-Membros, ou unidades subnacionais, ou entes federados ou, ainda, entidades descentralizadas. Não por acaso, a palavra "federal" está ligada à expressão foederatio, que significa aliança, união.

Os Estados Unidos da América são um exemplo de Federação moderna. Foi ela concebida e originada em 1787, por intermédio da Convenção da Philadelphia, na qual as treze ex-colônias inglesas se reuniram para apresentar uma Constituição ${ }^{17}$ em que abdicavam de suas respectivas soberanias e formavam um novo Estado ${ }^{18}$.

Apesar de o modelo americano constituir-se como a primeira e efetiva Federação, o delineamento dessa estrutura já havia sido objeto de estudo e experiências anteriores. Em 1744, Charles-Louis de Secondat, o Barão de Montesquieu, por exemplo, retratou em seu "Do Espírito das Leis" (Livro IX, Capítulo I) a concepção da república federativa, considerando-a como "uma convenção pela qual vários corpos políticos consentem em

15 Manoel Gonçalves Ferreira Filho. Curso de direito constitucional. 29a ed. rev. e atual. São Paulo: Saraiva, 2002, pp. 51-52.

16 Curso de direito constitucional. $21^{\mathrm{a}}$ ed. São Paulo: Saraiva, 2000, p. 155.

17 Em princípio, porém, o objetivo primeiro da Convenção da Philadelphia foi o de discutir as alterações de artigos da Confederação americana.

18 A instauração efetiva da Federação americana somente ocorreu em 1789, apesar de a Constituição ter se dado no ano de 1787. Nesse sentido, José Luiz de Anhaia Mello esclarece: "Finalmente, ratificada a Constituição pelas Assembléias de onze Estados, o Congresso deitou uma resolução, em 13 de setembro de 1788, pondo em vigor o texto constitucional, fixando data para a eleição dos eleitores presidenciais. (...) Reunido o Congresso em 30 de março de 1789, sob a presidência de George Washington, já na qualidade de primeiro Presidente dos Estados Unidos da América do Norte, começou a existir, efetivamente, a primeira Federação de Estados no cenário mundial" (O Estado Federal e as suas novas perspectivas. São Paulo: Max Limonad, 1960, p. 24). 


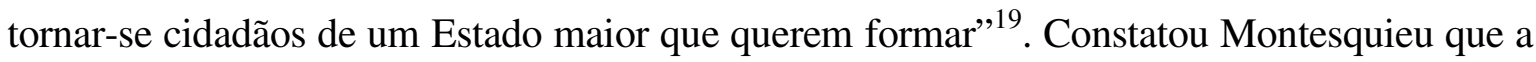
estrutura desse tipo de república viabilizaria sua permanência por longo tempo, uma vez que conseguia reunir o proveito inerente ao governo republicano e à monarquia, afastando-a de todas as dificuldades ${ }^{20}$.

\subsubsection{Principais elementos do Estado federal}

A forma federativa não é uniforme para todos os Estados que a adotam. Bem por isso, não é rara a existência de Estados que apresentem características diferentes entre si, embora nem por isso sejam excluídos do modelo federativo.

É comum alguns países apresentarem elementos diferenciados que, à primeira vista, os separariam da definição clara de Federação; no entanto, observados esses mesmos Estados sob uma ótica genérica, é possível chegar à conclusão de que neles está presente o arcabouço federativo.

Na verdade, algum elemento contido numa Federação também poderia estar presente num Estado unitário, mas nem todas as características fundamentais da estrutura federativa se apresentariam de forma concomitante nesse modelo unitário ${ }^{21}$. É justamente essa nuance que permite distinguir a forma federativa de outros modelos existentes.

19 Montesquieu. Do Espírito das Leis. In: Os Pensadores. Trad. Editora Bertrand Brasil. São Paulo: Nova Cultural, 1997, p. 173, v. 1. Título original: De l'Esprit des lois, ou du rapport que les lois doivent avoir avec la constitution de chaque gouvernement, les mouers, le climat, la religion, le commerce, etc.

20 De fato, essa ideia de perenidade do modelo federativo está presente no pensamento de Montesquieu: “Assim, há grandes indícios de que os homens teriam sido obrigados a viver sempre sob o governo de um só, se não tivessem imaginado um tipo de constituição que possui todas as vantagens internas do governo republicano e a força externa da monarquia. Refiro-me à república federativa. [...]

É graças a tais associações que a Holanda, a Alemanha e as Ligas Suíças são encaradas, na Europa, como repúblicas eternas. [...]

Esse tipo de república, capaz de resistir à força exterior, pode manter-se em sua grandeza sem que o interior se corrompa: a forma dessa sociedade previne todos os inconvenientes. [...]

Se qualquer sedição ocorresse em um dos membros confederados, os outros poderiam apaziguá-lo. Se abusos se introduzissem em alguma parte, seriam corrigidos pelas outras partes sadias. Este Estado poderia perecer numa das partes sem que as demais também perecessem; a confederação poderia ser dissolvida permanecendo os confederados soberanos.

Composta de pequenas repúblicas, gozaria da benignidade do governo interno de cada uma e, no que diz respeito ao exterior, teria, pela força da associação, todas as vantagens das grandes monarquias". (Do Espírito das Leis. In: Os Pensadores. Trad. Editora Bertrand Brasil. São Paulo: Nova Cultural, 1997, pp. 173-174, v. 1. Título original: De l'Esprit des lois, ou du rapport que les lois doivent avoir avec la constitution de chaque gouvernement, les mouers, le climat, la religion, le commerce, etc.)

21 Oswaldo Aranha Bandeira de Mello. Natureza jurídica do Estado Federal. São Paulo: Editora Revista dos Tribunais, 1937, p. 128. 
Com vistas a facilitar essa identificação, é possível determinar alguns elementos que necessitam estar presentes para caracterizar um Estado como federal. São eles:

a) Presença de, no mínimo, dois entes federados

Um desses entes será o governo central, cuja autoridade se estende a todo o território do Estado. Os demais entes se referem às unidades descentralizadas, as quais exercerão suas funções nos limites territoriais e no nível a ser definido pela Constituição.

\section{b) Indissolubilidade}

Não é possível aceitar a concepção de Federação se houver a probabilidade de separação das unidades que a formam. O Estado Federal é, assim, constituído pela união indissolúvel das unidades descentralizadas, não se permitindo a ocorrência de secessão.

c) Descentralização administrativa, política e financeira previstas na Constituição

Como anteriormente afirmado, a Federação é uma espécie de Estado descentralizado, caracterizando-se pelo nível de autonomia política, administrativa e financeira conferida às unidades que o compõem.

A autonomia política refere-se à possibilidade de os entes federados ditarem ordenamentos particulares em consonância com o ordenamento geral.

A aptidão de as unidades subnacionais se organizarem para o exercício de suas funções representa a autonomia administrativa.

Já a autonomia financeira diz respeito à capacidade de os Estados-membros adquirirem receitas para bem desempenhar as funções definidas na Constituição, seja essa obtenção de recursos originada por intermédio do exercício da competência tributária própria do ente, seja por meio de transferências intergovernamentais (redistribuição vertical de recursos, em que os recursos são obtidos por intermédio de outros entes da Federação).

d) Repartição de competências entre os entes federados

A existência de unidades descentralizadas e suas respectivas autonomias já pressupõem a necessidade de repartição de competências entre tais unidades. A Constituição irá definir a quais entes e em que grau serão distribuídas as competências política, administrativa e financeira.

e) Atuação dos entes federados na formação da vontade nacional 
A participação das unidades descentralizadas na criação da vontade do Estado Federal é um sistema assegurado pela Constituição e que permite distinguir, de pronto, a diferença existente entre o Estado unitário descentralizado e o modelo federativo.

Além de constituir e ser elemento da atividade da soberania, a lei de participação é o instrumento pelo qual "tomam os Estados-membros parte no processo de elaboração da vontade política válida para toda a organização federal, intervêm com voz ativa nas deliberações de conjunto, contribuem para formar as peças do aparelho institucional da Federação",22.

f) Presença de uma Constituição rígida e de um órgão judicial com a função de exercer o controle de constitucionalidade das leis

Todos os elementos presentes na Federação, inclusive as competências, são estabelecidos, ditados e assegurados pela Constituição. É por esse motivo que a Carta Constitucional deve ser rígida, de forma a impedir que suas premissas sejam modificadas com facilidade, sob pena de se colocar em risco a perenidade do Estado Federal.

Da mesma forma, torna-se indispensável a existência de um órgão judicial superior, que tem como finalidade o exercício do controle da constitucionalidade das leis - inclusive daquelas editadas pelos entes subnacionais -, a guarda dos princípios e ditames da Constituição e a garantia da Federação.

\subsubsection{Classificação dos Estados federais}

Os Estados federais podem ser classificados de acordo com determinados critérios, quais sejam: a) quanto à formação; b) quanto à forma de organização; c) quanto ao equilíbrio.

No que diz respeito à formação, os Estados federados originam-se por intermédio da agregação ou segregação.

A agregação ocorre mediante a união de Estados que abrem mão de suas respectivas soberanias para formar um novo ente, ou seja, a Federação. Exemplo principal dessa formação é a criação dos Estados Unidos da América, precursores do modelo federalista moderno.

22 Paulo Bonavides. Ciência política. $10^{\mathrm{a}}$ ed. rev. e atual. São Paulo: Malheiros, p. 181. 
A descentralização de um ente unitário em setores menores, os quais passam a ganhar autonomia, caracteriza a Federação por segregação. A formação do federalismo brasileiro, por exemplo, deu-se por segregação, já que, por meio do Decreto $\mathrm{n}^{\circ} 1$, de 15 de novembro de 1889 , as províncias obtiveram autonomia e deram origem aos estados, os quais estruturavam a federação brasileira ${ }^{23}$.

A organização de um Estado federal pode se dar pela forma dual ou cooperativa. Quando a competência dos entes que fazem parte da federação se apresenta bem demarcada, ou seja, sem a interferência ou sobreposição da competência de um ente sobre o outro, diz-se que o Estado assim constituído é dualista, caracterizado por apresentar como elemento predominante a repartição horizontal de competências.

No Estado federal cooperativo prevalece a repartição vertical de competências, significando que para um mesmo tema pode haver a atuação de entes de diferentes níveis. Nessa hipótese, normalmente incumbe ao governo central o estabelecimento de normas gerais $^{24}$.

O caráter cooperativo, porém, não ocorre apenas na esfera da repartição de competências, mas também em outros aspectos da Federação. Como lembra Reinhold Zippelius $^{25}$, a expressão "cooperativo" é utilizada para demonstrar que a união de esforços dos entes central e subnacional será coordenada para a obtenção de uma finalidade universal da Federação ${ }^{26}$. A repartição de receitas tributárias é um exemplo do exercício do

23 Eis os principais artigos do mencionado decreto: "Art. $1^{\circ}$. Fica proclamada provisoriamente e decretada como a forma de govêrno da nação brasileira a República Federativa. Art. $2^{\circ}$. As províncias do Brasil, reunidas pelo laço da federação, ficam constituindo os Estados Unidos do Brasil. Art. $3^{\circ}$. Cada um desses Estados, no exercício de sua legítima soberania, decretará oportunamente a sua constituição definitiva, elegendo os seus corpos deliberantes e os seus governos locais". O artigo $1^{\circ}$ da Constituição de 1891 também explicita as nuances da federação brasileira ao declinar: "Art. $1^{\circ}$. A Nação Brazileira adopta como fórma de governo, sob o regimen representativo, a Republica Federativa proclamada a 15 de novembro de 1889 , e constitue-se, por união perpetua e indissolúvel das suas antigas províncias, em Estados Unidos do Brazil".

24 Jorge Miranda (Teoria do Estado e da Constituição. Rio de Janeiro: Forense, 2005, p. 312) estabelece as principais características dos sistemas dualista e cooperativo: "No federalismo clássico (Estados Unidos, Suíça), procede-se a uma repartição horizontal ou material: o dualismo de soberania envolve um dualismo legislativo e executivo (o Estado federal faz e executa as suas leis, e o mesmo fazem os Estados federados). No federalismo dito cooperativo (Alemanha), tende-se a uma repartição vertical: o Estado federal legisla ou define as bases gerais da legislação e os Estados federados executam ou desenvolvem as bases gerais".

25 Teoria Geral do Estado. Tradução de Karin Praefke-Aires Coutinho. Coord. J. J. Gomes Canotilho. Lisboa: Fundação Calouste Gulbenkian, 1997, p. 512.

26 O mesmo autor (Op. cit., p. 512) afirma: "As funções dos órgãos centrais da federação (órgãos federais) e as dos órgãos dos Estados membros completam-se reciprocamente, formando uma unidade de acção em termos de Estado global. A forma política do Estado federal é um corpo racionalmente subdividido cujas partes se coordenam no sentido de desenvolverem permanente eficácia comum. [...] Como esquema cooperativo, em sentido restrito, pode designar-se aquele que acarreta uma 'obrigação ao 
federalismo cooperativo no âmbito financeiro, uma vez que há a atuação de uma unidade federada na receita tributária de outra ${ }^{27}$.

No que se refere ao equilíbrio da Federação, esta pode ser simétrica ou assimétrica. Conforme defende Dircêo Torrecillas Ramos ${ }^{28}$,

o ideal no sistema federal simétrico é que: cada Estado mantenha, essencialmente, o mesmo relacionamento para com a autoridade central; a divisão de poderes entre os governos central e dos Estados seja virtualmente a mesma em cada caso; a representação no governo central esteja na mesma base para cada componente político e o suporte das atividades do governo central seja igualmente distribuído.

As características acima apontadas revelam a existência de simetria na federação. Numa primeira análise decorreria logicamente, então, que a ocorrência de desarmonia em qualquer um desses aspectos evidenciaria uma assimetria no sistema federativo. No entanto, nem sempre essa igualdade de tratamento e perspectivas seria salutar para o bom desempenho da federação, principalmente para Estados que apresentam diferenças regionais importantes, como é o caso do Brasil. É que, uma vez constatada a existência de desproporções entre os entes federativos, muitas vezes a solução será o tratamento diferenciado para cada uma dessas unidades subnacionais, de forma a proporcionar um futuro nivelamento de tratamento ${ }^{29}$.

\subsection{A Federação e a atividade financeira do Estado}

As necessidades públicas são aquelas ditadas pelo Estado por intermédio de seu ordenamento (inclusive a Constituição) e que reproduzem os anseios da sociedade, não se confundindo, por isso, com as necessidades do Estado ou com os interesses dos particulares ou, ainda, com os de determinada coletividade ${ }^{30}$. A satisfação dessas necessidades constitui,

entendimento', quer dizer, o dever das partes no sentido de se harmonizarem entre elas e, caso necessário, aceitarem compromissos".

27 José Afonso da Silva. Comentário contextual à Constituição. São Paulo: Malheiros, 2005, p. 662.

28 O federalismo assimétrico. São Paulo: Plêiade, 1998, p. 96.

29 Nesse sentido, Nelson de Freitas Porfírio Júnior (Federalismo, Tipos de Estado e Conceito de Estado Federal. In: CONTI, José Mauricio (org.). Federalismo fiscal. Barueri: Manole, 2004, p. 10) afirma: "Em outras palavras, um federalismo ideal (que pode ser denominado simétrico) pode não conduzir a bons resultados. Ao contrário, o tratamento diferenciado de cada unidade autônoma, respeitando as necessidades e particularidades de cada uma, poderá gerar um desenvolvimento global ao país. Aplicase, aqui, o conceito antigo de isonomia - tratar igualmente os iguais e desigualmente os desiguais, na medida de suas desigualdades".

30 Regis Fernandes de Oliveira. Curso de direito financeiro. São Paulo: Editora Revista dos Tribunais, 2006, p. 58. 
na verdade, um dos fins de todo Estado, sem o qual não há como se alcançar o bem comum do seu povo.

Como forma de atender essas necessidades, é preciso que o Estado obtenha recursos suficientes, administre-os com eficácia e os direcione para a execução de serviços e obtenção de bens essenciais à sociedade. A aquisição de recursos, sua gestão e a consequente aplicação dessas entradas para satisfação das necessidades públicas nada mais representam que a atividade financeira estatal.

Em tese, a estrutura de uma Federação, sob o aspecto do Direito Financeiro e da Ciência das Finanças, permitiria melhor desempenho e controle da atividade financeira do Estado.

A aproximação das unidades descentralizadas em relação às matérias e problemas surgidos permite maior versatilidade da Federação e a cooperação dos demais entes no tratamento dessas questões ${ }^{31}$. A transferência de recursos de um ente subnacional para outro, por exemplo, pode ser a solução para os problemas regionais enfrentados pelo último, sem colocar em risco a hegemonia e a estrutura da Federação. Nesse sentido, Alexis de Tocqueville ressalta as vantagens do sistema federativo em relação ao modelo centralizado ao afirmar que, "nas grandes nações centralizadas, o legislador é obrigado a dar às leis caráter uniforme, que não comporta a diversidade dos lugares e dos costumes; não estando a par dos casos particulares, não pode proceder senão através de regras gerais ${ }^{\text {”2 }}$. Na federação isso é evitado.

Na geração de determinados bens e serviços, o Estado federal poderá se organizar de tal forma que referidas atividades sejam desempenhadas pelo ente (governo central ou unidades descentralizadas) que melhor seja capacitado a essa tarefa específica,

31 A capacidade de flexibilização da Federação e a cooperação das unidades descentralizadas são pontos bem destacados por Reinhold Zippelius (Teoria geral do Estado. $3^{\mathrm{a}}$ ed. Tradução de Karin Praefke-Aires Coutinho. Lisboa: Fundação Calouste Gulbenkian, 1997, pp. 514-515. Título original: Allgemeine Staatslehre): "Uma vantagem da estrutura federativa reside ainda na obtenção de flexibilidade e na proximidade em relação aos assuntos. Em muitas questões, os órgãos centrais da federação e os órgãos dos Estados federados (ou a sua representação central) vêem-se obrigados a procurar, sempre de novo, um acordo aceitável para todos e a coordenar-se entre eles. Assim, a ordem federativa está, de um modo específico, aberta para uma coordenação mútua, susceptível de se adaptar inclusivamente a novas necessidades e situações. - Graças à pluralidade das unidades políticas de decisão, aumenta também a capacidade do sistema político global de reagir, com 'proximidade à matéria', às diferentes necessidades das regiões e, em especial, de adaptar-se a qualquer mudança das circunstâncias (...)".

32 A democracia na América. Tradução de J. A. G. Albuquerque. In: Os Pensadores. São Paulo: Abril Cultural, 1979, p. 213-214. 
possibilitando, assim, economia na utilização de recursos e maior eficiência nas funções estatais.

O controle financeiro dos entes federados também, em princípio, seria melhor realizado numa Federação, seja em razão da fiscalização exercida pelos poderes presentes em cada unidade descentralizada (órgãos representativos dos Estados-membros, por exemplo), seja pelo fato de que, em relação aos entes subnacionais, os cidadãos estariam mais próximos do governante, o que facilitaria um controle social mais eficaz.

Todas essas características e os exemplos acima relatados, para surtirem efeitos satisfatórios, dependerão, no entanto, de como estará estruturada a Federação sob o aspecto financeiro. De fato, o delineamento referente às competências tributárias, à política de transferências intergovernamentais e à distribuição das funções entre os entes federados é que permitirá apontar sucessos ou deficiências na atividade financeira de um determinado Estado federal.

Não por acaso, com o intuito de compreender as dificuldades da Federação, identificar os pontos que merecem ser aprimorados e estabelecer as ações adequadas para a solução dos problemas existentes, imprescindível o estudo do federalismo fiscal, seus conceitos e princípios.

\subsection{Federalismo fiscal}

No Estado federal, a convivência entre o governo central e os entes subnacionais se materializa pelas mais diversas formas. Uma delas é justamente a de ordem financeira, de forma que a distribuição de competências entre esses entes será de vital importância para determinar a eficiência do Estado no alcance de suas finalidades. Sob esse aspecto, não se pode afirmar a existência de um método único e correto para que uma federação alcance níveis ótimos na adequada geração, distribuição e alocação de recursos.

De fato, as atribuições das esferas governamentais oscilarão de acordo com o nível de descentralização existente no Estado federal, cabendo às suas próprias estruturas a determinação da sistemática mais condizente com as características e os fins do ente estatal. 
A partir das premissas acima traçadas, transparece a importância do federalismo fiscal que, segundo José Mauricio Conti ${ }^{33}$, compreende "a análise da maneira pela qual está organizado o Estado, qual é o tipo de federação adotado, qual é o grau de autonomia dos seus membros, as incumbências que lhe são atribuídas e, fundamentalmente, a forma pela qual serão financiadas"34.

Semelhante alcance tem a definição de Sérgio Prado ${ }^{35}$, para quem o federalismo fiscal representa "o conjunto de problemas, métodos e processos relativos à distribuição de recursos fiscais em federações, de forma tal que viabilizem o bom desempenho de cada nível de governo no cumprimento dos encargos a ele atribuídos". O mesmo autor complementa que o federalismo fiscal "remete para as relações entre atribuição de impostos, distribuição intergovernamental do gasto público e, principalmente, transferências intergovernamentais" $" 36$.

33 Federalismo fiscal e fundos de participação. São Paulo: Editora Juarez de Oliveira, 2001, pp. 24-25.

34 De acordo com Marcos Mendes, é possível afirmar que, sob a ótica política, o federalismo apresenta uma acepção ampla, uma vez que representa a distribuição de poderes no âmbito constitucional e político; já do ponto de vista econômico, tal acepção é mais restrita, uma vez que diz respeito à adequada distribuição de receitas e despesas públicas entre as esferas governamentais (Federalismo fiscal. In: ARVATE, Paulo; BIDERMAN, Ciro (org.). Economia do setor público no Brasil. Rio de Janeiro: Elsevier, 2004, p. 460). Wallace Eugene Oates (An Essay on Fiscal Federalism. In: Journal of Economic Literature. Nashville: American Economic Association, set. 1999, v. 37, n³ 3, pp. 1120-1121, nota de rodapé n 2, disponível também em http://www.jstor.org/pss/2564874, acessado em 02.06.1999) não discrepa do entendimento de que há a mesma diferença entre ambas as concepções de federalismo, mas propõe um alcance maior à expressão "federalismo fiscal", de forma a abarcar uma gama maior de assuntos referentes às relações verticais envolvendo o setor público e não apenas uma visão mais restrita no tocante às questões orçamentárias. No original: "This economic use of the term 'federalism' is somewhat different from its standard use in political science, where it refers to a political system with a constitution that guarantees some range of autonomy and power to both central and decentralized levels of government. For an economist, nearly all public sectors are more or less federal in the sense of having different levels of government that provide public services and have some scope for de facto decision-making authority (irrespective of the formal constitution). In retrospect, it seems to me that the choice of the term 'fiscal federalism' was probably an unfortunate one, since it suggests a narrow concern with budgetary matters. The subject of fiscal federalism, as I suggest above, encompasses much more, namely the whole range of issues relating to the vertical structure of the public sector".

35 Equalização e federalismo fiscal; uma análise comparada: Alemanha, Índia, Canadá, Austrália. Rio de Janeiro: Konrad-Adenauer-Stiftung, 2006, p. 15 (original apresenta-se em destaque).

36 Equalização e federalismo fiscal; uma análise comparada: Alemanha, Índia, Canadá, Austrália. Rio de Janeiro: Konrad-Adenauer-Stiftung, 2006, p. 15. O relacionamento financeiro entre os entes da Federação não é o único aspecto a ser considerado. Segundo Rogério Leite Lobo (Federalismo fiscal brasileiro: discriminação das rendas tributárias e centralidade normativa. Rio de Janeiro: Editora Lumen Juris, 2006, p. 71), o federalismo fiscal desenvolve-se "na verificação da compatibilidade entre os encargos administrativos cometidos aos entes federativos e as rendas destinadas a cada qual para o imprescindível custeio, além de remeter diretamente aos cânones da isonomia e da autonomia, e, indiretamente, a vários outros valores e princípios (solidariedade, democracia, proporcionalidade, subsidiariedade, etc.) que lhe são tangentes". Uma concepção puramente econômica de federalismo fiscal é apresentada por Marcos Mendes (Federalismo fiscal. In: ARVATE, Paulo; BIDERMAN, Ciro (org.). Economia do setor público no Brasil. Rio de Janeiro: Elsevier, 2004, p. 422) quando declara que "pode ser definido como a divisão de tarefas entre os diferentes níveis de governo: quem (que níveis de governo) deve arrecadar cada um dos tributos do país e quem deve ofertar cada um dos serviços públicos 
Não por acaso, Wallace Eugene Oates afirma que o conteúdo do federalismo fiscal é a análise de "quais funções e instrumentos são melhor centralizados e quais são melhor assentados na esfera dos níveis descentralizados de governo". Segundo ele, o federalismo fiscal, ramo da Ciência das Finanças, preocupa-se com a estrutura vertical do setor público e é responsável pela análise das funções atinentes a cada um dos níveis governamentais e à forma como cada um deles se relacionam entre si como, por exemplo, por intermédio das transferências intergovernamentais ${ }^{37}$.

Percebe-se, então, que por intermédio da análise do federalismo fiscal é possível averiguar os meios e as alternativas utilizados pelo Estado para o cumprimento satisfatório de suas finalidades. Verifica-se, a partir daí, que uma proveitosa repartição de competências entre as esferas governamentais é capaz de proporcionar o desenvolvimento de determinado país e, por consequência, da população que nele vive. A desarmonia nesse compartilhamento provocará, no mínimo, desigualdades regionais e retardo no nível de crescimento.

Exatamente por esse motivo, mostra-se importante o estudo de alguns dos fundamentos do federalismo fiscal, como forma de compreender seu verdadeiro propósito.

\subsection{Princípios do federalismo fiscal e o exercício das funções fiscais}

As bases econômica e social servem de parâmetro para estabelecer os principais fundamentos do federalismo fiscal. De acordo com tais critérios, é possível indicar a existência de três princípios, quais sejam, o do benefício, o da compensação fiscal e o da distribuição centralizada ${ }^{38}$.

Verificar-se-á, a seguir, que alguns desses princípios possuem relação íntima com o papel exercido pela política orçamentária na sua atividade de permitir a alocação de recursos (função alocativa), organizar a distribuição da renda e da riqueza (função distributiva) e

(saúde, saneamento, educação, limpeza, iluminação, segurança pública, estabilidade macroeconômica, assistência aos pobres etc.)".

37 An Essay on Fiscal Federalism. In: Journal of Economic Literature. Nashville: American Economic Association, set. 1999, v. 37, n 3, p. 1120. Disponível também em http://www.jstor.org/pss/2564874, acessado em 02.06.1999. No original: “[...] we need to understand which functions and instruments are best centralized and which are best placed in the sphere of decentralized levels of government. This is the subject matter of fiscal federalism. As a subfield of public finance, fiscal federalism addresses the vertical structure of the public sector. It explores, both in normative and positive terms, the roles of the different levels of government and the ways in which they relate to one another through such instruments as intergovernmental grants".

38 José Mauricio Conti. Federalismo fiscal e fundos de participação. São Paulo: Juarez de Oliveira, 2001, pp. 28-29. Ver, também, Carlos Alberto Longo e Roberto Luis Troster. Economia do setor público. São Paulo: Atlas, 1993, p. 148. 
assegurar a estabilização econômica (função estabilizadora) ${ }^{39}$. O reconhecimento da importância dessas funções é prova de que a atividade financeira estatal não se presta apenas à mera arrecadação de recursos para a satisfação das necessidades públicas imediatas, mas também pode apresentar escopo econômico e social ${ }^{40}$.

A classificação das funções fiscais em alocativa, distributiva e estabilizadora foi proposta por Richard Abel Musgrave em 1957 e desenvolvida em seus escritos posteriores $^{41}$. A teoria proposta investiga, sob o prisma da Economia Pública, as operações relativas aos objetivos da política orçamentária, não levando em consideração um determinado tipo de Estado descentralizado, mas um "Estado imaginário, onde prevalecem padrões eficientes de planejamento fiscal" ${ }^{\prime 42}$.

Passa-se à análise de cada uma dessas funções e a sua correspondência com os princípios do federalismo fiscal.

39 Teoria das finanças públicas: um estudo de economia governamental. Tradução de Auriphebo Berrance Simões. São Paulo: Atlas; Brasília: INL, 1973, v. 1, pp. 24-25. Título original: The theory of public finance: a study in public economy. No decorrer do presente trabalho será possível verificar que a conjugação dessas funções no Estado federal representa um desafio ainda maior, tendo em vista os diversos níveis de governo (entes federados) responsáveis pela sua implementação.

40 Segundo Richard Abel Musgrave (Teoria das finanças públicas: um estudo de economia governamental. Tradução de Auriphebo Berrance Simões. São Paulo: Atlas; Brasília: INL, 1973, v. 1, p. 39. Título original: The theory of public finance: a study in public economy), "a maioria das pessoas veio a reconhecer que o processo de receita-despesas do governo deve, necessariamente, ter efeitos sociais e econômicos e que estes podem ser dirigidos, de maneira útil, para finalidades indiretamente ligadas ao objetivo imediato de satisfazer necessidades públicas”. Parece mais nítida essa constatação de Musgrave na medida em que se observa a concepção de Estado após o século XIX, período no qual se iniciou a expansão da política intervencionista estatal e se estruturou um fim extrafiscal, e não apenas fiscal, à atividade financeira. Para uma compreensão maior sobre o neutralismo e o intervencionismo estatal e a sua relação com a atividade financeira do Estado, ver Carlos M. Giuliani Fonrouge (Derecho Financiero. $2^{\mathrm{a}}$ ed. ampl. e atual. Buenos Aires: Depalma, 1970, v. 1, pp. 16-17).

41 O primeiro artigo de Musgrave a respeito do tema foi "A Multiple Theory of Budget Determination" (Finanzarchiv, N. F. 17, 1956/1957, Heft 3, pp. 333-343, também disponível em http://autoren.mohr.dekl/fa/musgrave_budget_determination.pdf, acessado em 03.06.2009). Após, seguiram-se vários textos discutindo a problemática das funções fiscais; dentre esses textos, podem ser citados: a obra The Theory of Public Finance (no Brasil, Teoria das finanças públicas: um estudo de economia governamental. Tradução de Auriphebo Berrance Simões. São Paulo: Atlas; Brasília: INL, 1973, v. 1 e 2) e os artigos intitulados "Approaches to a fiscal theory of political federalism" (In: Public Finances: Needs, Sources, and Utilization. Cambridge: National Bureau of Economic Research, Inc, 1961, pp. 97-134, também disponível em http://www.nber.org/chapters/c2274.pdf, acessado em 03.06.2009) e "The three branches revisited" (In: Atlantic Economic Journal, v. 17, no 1, mar. 1989, pp. 1-7, também disponível em http://findarticles.com/p/articles/mi_hb6413/is_n1_v17/ai_n28583575/, acessado em 02.06.2009).

42 Teoria das finanças públicas: um estudo de economia governamental. Tradução de Auriphebo Berrance Simões. São Paulo: Atlas; Brasília: INL, 1973, v. 1, p. 25. Título original: The theory of public finance: a study in public economy. 


\subsubsection{Princípio do benefício e a função fiscal alocativa}

De acordo com o princípio do benefício, as necessidades públicas devem ser atendidas pelas esferas governamentais correspondentes à magnitude ou especificidade da demanda. Desse modo, é razoável conceber que determinados serviços públicos de grande dimensão ou importância deverão ser realizados pelo órgão central, mas não surtirão a finalidade desejada se o forem por entes subnacionais, de âmbito estadual ou local.

A defesa nacional e a regulação dos $\operatorname{mercados}^{43}$ são exemplos de atividades que, claramente, devem ser comandadas pelo governo central, tendo em vista o interesse de âmbito nacional que as permeia.

Determinados serviços como iluminação pública, coleta de lixo e asfaltamento são melhor gerenciados e executados por intermédio da ação de governos locais, vez que dirigidos a uma localidade determinada. Nos exemplos citados, a transferência dessas atividades para o acompanhamento a cargo do órgão central tornaria dispendiosa e até mesmo impossível a realização das tarefas, principalmente quando elas tivessem que ser executadas em locais distantes da sede do poder central.

De outro lado, a construção de usinas hidrelétricas normalmente é de competência de governos de âmbito regional, seja porque as esferas locais não possuem condições (ou interesse) de arcar com os altos custos da empreitada, seja porque a atuação única do governo central não seria suficiente para atender toda a demanda nacional.

O princípio do benefício possui estreita relação com o exercício da função fiscal alocativa, que diz respeito à maneira como o Estado, no oferecimento de bens e serviços públicos, deve satisfazer as necessidades essenciais da população ${ }^{44}$. Pressupõe a vinculação

43 Richard Abel Musgrave (Teoria das finanças públicas: um estudo de economia governamental. Tradução de Auriphebo Berrance Simões. São Paulo: Atlas; Brasília: INL, 1973, v. 1, p. 27. Título original: The theory of public finance: a study in public economy) destaca a importância da utilização da política orçamentária do Estado para a eliminação das imperfeições de mercado: "Para começar, surge uma oportunidade para ajustamento quando, por motivos institucionais, a organização da indústria impede a livre entrada, de modo que a alocação diverge da que é obtida sob condições de pura concorrência. Este é o caso geral de controle monopolístico. Na determinação de uma política orçamentária eficiente deve ser levada em conta a existência de imperfeições de mercado, ao mesmo tempo em que essas mesmas políticas podem ser usadas para eliminá-las”.

44 É reconhecida por Richard Abel Musgrave a dificuldade na definição do que vem a ser necessidade pública; no entanto, o autor procura dividi-la em dois tipos, quais sejam, as necessidades sociais e as necessidades meritórias. As necessidades sociais seriam aquelas "que devem ser satisfeitas através de serviços que precisam ser consumidos por todos em quantidades iguais [defesa nacional, por exemplo]. As pessoas que não pagam pelos serviços não podem ser excluídas dos benefícios que deles resultam; e, já que não podem ser excluídas, jamais se disporão a pagar voluntariamente. Daí a razão pela qual o mercado não pode satisfazer tais necessidades" (Teoria das finanças públicas: um estudo de economia governamental. Tradução de Auriphebo Berrance Simões. São Paulo: Atlas; Brasília: INL, 1973, v. 1, 
entre a atividade governamental de satisfação das necessidades públicas e a coletividade financiadora desses serviços e beneficiada por eles ${ }^{45}$.

As balizas acima traçadas permitem considerar a possibilidade de se instituir uma divisão nas atividades dos entes governamentais em busca de um melhor atendimento das necessidades da população, inclusive adotando-se o princípio do benefício.

$\mathrm{Na}$ descentralização dessas atribuições procurar-se-á dirigir ao núcleo central de governo somente os serviços públicos que amparem interesses de âmbito nacional ou que representem ganho de escala. Afora essas situações, a destinação de recursos será mais proveitosa na medida em que a prestação de serviços públicos for de responsabilidade do ente governamental de nível local ou regional, localizado próximo aos favorecidos por aqueles serviços ${ }^{46}$.

pp. 28-29. Título original: The theory of public finance: a study in public economy). Já as necessidades meritórias seriam as que poderiam ser satisfeitas pelo mercado, mas que se tornam "necessidades públicas se consideradas de tal modo meritórias que sua satisfação seja suprida através do orçamento público, além daquilo que é provido pelo mercado e pago pelos compradores particulares. (...) Os serviços públicos que visam à satisfação dessas necessidades incluem itens, tais como: merendas escolares, subsídio para casas de baixo custo e educação gratuita" (Op. cit., p. 34). A divisão de Musgrave é útil do ponto de vista da Economia Pública e para a melhor compreensão da função fiscal alocativa. A análise das várias teorias a respeito das necessidades públicas, porém, não constitui objeto do presente estudo, motivo pelo qual o estudo não se desenvolverá nesse ponto. Cabe ressaltar, apenas, que sob o aspecto do Direito Financeiro adota-se a definição de necessidades públicas como aquelas que se referem às exigências de um número indefinido de pessoas da sociedade, necessidades essas que são definidas no ordenamento jurídico por intermédio de uma decisão política, isto é, do próprio Estado.

45 Richard Abel Musgrave (Teoria das finanças públicas: um estudo de economia governamental. Tradução de Auriphebo Berrance Simões. São Paulo: Atlas; Brasília: INL, 1973, v. 1, pp. 30-31. Título original: The theory of public finance: a study in public economy) ressalta, porém, que em algumas hipóteses, como no caso das necessidades sociais, não existe uma relação direta entre a satisfação obtida pelo indivíduo e a sua contribuição para o financiamento do serviço prestado. Eis a explicação do autor: "Tal é, pelo menos, o caso em que o consumidor não é mais do que um entre muitos e qualquer contribuição que possa fazer cobre apenas uma pequena parte do custo total. Consideremos, por exemplo, itens como um projeto de controle de enchentes, cujos benefícios mais gerais cobrem uma região inteira; uma campanha sanitária que eleve o nível geral de saúde em uma certa área; despesas com o sistema judiciário, que garante a segurança interna e impõe o cumprimento de obrigações contratuais; ou proteção contra a agressão estrangeira. Tudo isso contribui para o bem-estar da comunidade inteira. Os benefícios resultantes serão comuns para todos os moradores de um certo local ou sociedade onde os serviços são prestados. Talvez alguns se beneficiem mais do que outros, mas todos sabem que seu benefício será independente de sua contribuição particular. Daí, como já dissemos, não se pode esperar do consumidor uma contribuição voluntária. O governo deve intervir e impor-se".

46 Nas palavras de Mauro Santos Silva (Teoria do federalismo fiscal: notas sobre as contribuições de Oates, Musgrave, Shah e Ter-Minassian. In: Nova Economia. Belo Horizonte, jan-abr de 2005, p. 121), “o governo central deve responder pela provisão de bens cujo consumo seja uniforme, em termos de preferência e em termos de quantidade individual demandada em todo o território federativo. Os governos estaduais assumiriam a responsabilidade pela provisão de itens com preferências regionais, e os governos locais responderiam pelos bens cujo perfil da demanda fosse específico de uma localidade". 
A descentralização da função alocativa, porém, encontra dificuldades em algumas situações nas quais não é possível efetuar uma divisão perfeita de atribuições entre as esferas governamentais responsáveis pela prestação de serviços públicos.

A problemática é bem demonstrada na doutrina da Ciência das Finanças por Charles M. Tiebout e Wallace Eugene Oates e mostra-se evidente quando se analisa a questão em relação à oferta de bens públicos de âmbito nacional, regional e local. É que, no caso dos bens e serviços públicos de âmbito nacional, não há a possibilidade de a população escolher em que níveis esses serviços devem ser prestados; na verdade, a preferência da população já é estabelecida pelo governo central, ao qual incumbe coordenar as necessidades nacionais ${ }^{47}$.

Já no fornecimento de bens e serviços públicos de âmbito local ou regional, é a população consumidora quem escolhe o ente subnacional que melhor satisfaça seu padrão de preferência, ou seja, os indivíduos é que se movem para aquele ente que atenda de uma forma mais favorável seu conjunto de necessidades ${ }^{48}$, fenômeno denominado por Wallace

47 De acordo com Wallace Eugene Oates (The theory of public finance in a federal system. In: Studies in Fiscal Federalism. Hants: Edward Elgar, 1991, p. 14), "os bens públicos, por sua natureza, envolvem concessões por parte de residentes de uma nação ou comunidade. Alguns indivíduos, por exemplo, preferem um alto nível de defesa nacional, enquanto outros desejariam um menor nível de gastos (e tributos) para esse papel. Entretanto, todos de uma determinada nação ou comunidade devem consumir a mesma quantidade de bens públicos. Dessa forma, aceitar isso é inevitável. Não há saída para esse problema no âmbito nacional; nós todos, por exemplo, necessitamos receber basicamente a mesma soma de defesa nacional" (Tradução livre do autor). No original: "Public goods, by their very nature, involve compromise among the residents of a nation or community. Some individuals, for example, may prefer a high level of national defence, while others would desire a lower level of expenditures (and taxes) for this function. However, everyone in a particular nation or community must consume the same set of public goods. Thus, compromise is inevitable. There is no way out of this problem at the national level; we all, for example, by necessity receive essentially the same amount of national defence".

48 Segundo Charles M. Tiebout (A Pure Theory of Local Expenditures. In: The Journal of Political Economy. Chicago: University of Chicago, out. 1956, p. 418, v. 64, n ${ }^{\circ}$ 5, também disponível em http://www.journals.uchicago.edu/doi/abs/10.1086/257839, acessado em 02.06.2009), essa característica de "mobilidade" dos indivíduos é o que diferencia o fornecimento de bens públicos de âmbito local dos de âmbito nacional. Segundo o autor, "o consumidor votante deve ser visto como o que escolhe aquela comunidade que melhor satisfaça seu padrão de preferência por bens públicos. Essa é a maior diferença entre o fornecimento local e o fornecimento central de bens públicos. No âmbito central, as preferências do consumidor votante são dadas, e o governo tenta ajustar para o padrão dessas preferências, enquanto que no âmbito local, os governos de diversos níveis possuem seus padrões de receita e gastos mais ou menos agrupados. Determinados esses padrões de receita e despesa, o consumidor votante se move para aquela comunidade cujo governo local melhor satisfaça seu conjunto de preferências. Quanto maior o número de comunidades e quanto maior a variação entre elas, mais perto o consumidor estará de completar a concretização de sua posição de preferência". No original: "The consumer-voter may be viewed as picking that community which best satisfies his preference pattern for public goods. This is a major difference between central and local provision of public goods. At the central level the preferences of the consumer-voter are given, and the government tries to adjust to the pattern of these preferences, whereas at the local level various governments have their revenue and expenditure patterns more or less set. Given these revenue and expenditure patterns, the consumer-voter moves to that community whose local government best satisfies his set of preferences. The greater the number of communities and the 
Eugene Oates como "voto com os pés"49. Proporciona-se, dessa forma, a concorrência horizontal entre esferas governamentais de mesmo nível, aprimorando os serviços prestados pelos entes e beneficiando, de modo geral, a federação.

Diante das características mencionadas, verifica-se que diversos fatores podem exercer influência direta na função alocativa quando esta é exercida de forma descentralizada. Dentre esses fatores, podem ser destacados: o processo de decisão coletiva dos beneficiários dos serviços públicos; a transferência dessas pessoas entre os entes subnacionais; e a convivência de ofertas de bens e serviços públicos semelhantes ou diferenciados entre governos de mesmo nível governamental ${ }^{50}$.

A criação de um hospital de grande porte em um pequeno município, por exemplo, não encontraria a demanda necessária da população local para sua utilização. O bem e serviço público prestados se mostrariam ociosos ou os municípios vizinhos deixariam de prestar o mesmo serviço com a expectativa de utilização daquele já servido pelo primeiro. A eficiência da função alocativa seria encontrada na transferência desse encargo a um nível governamental regional - e, em algumas situações, ao ente central -, com a finalidade de atender as necessidades públicas de um maior número de municípios.

Problema também pode ocorrer no fato de, diante da possibilidade de as pessoas originalmente fixadas no âmbito territorial de uma esfera governamental se transferirem para outras regiões, impossibilitar a estruturação ideal de uma economia de escala de acordo com

greater the variance among them, the closer the consumer will come to fully realizing his preference position".

$49 \mathrm{O}$ autor (The theory of public finance in a federal system. In: Studies in Fiscal Federalism. Hants: Edward Elgar, 1991, pp. 14-15) afirma: "Se, por exemplo, um indivíduo está descontente com o padrão de gastos e a estrutura tributária em sua comunidade, poderá sempre, num sistema federal, deslocar-se para outra comunidade que forneça um 'pacote fiscal' que melhor atenda seus gostos. Dessa forma, numa economia federal, a eficiência do recurso da alocação em relação aos bens públicos locais tende a ser elevada à categoria do assim denominado 'voto com os pés'. Da mesma forma que os consumidores adquirem bens privados, eles podem até certo ponto selecionar uma comunidade que forneça bens públicos e tributos de acordo com seus gostos. Dessa forma, podemos conceber um sistema federal no qual as comunidades fornecem variados níveis e combinações de bens públicos e no qual os indivíduos se fixam, pelo menos até certo ponto, de acordo com suas preferências fiscais". No original: "If, for example, an individual is unhappy with the pattern of expenditures and the structure of taxes in his community, he can, in a federal system, always move to another community which provides a 'fiscal package' better suited to his tastes. Thus, in a federal economy, the efficiency of resource allocation as regards local public goods tends to be enhaced by so-called 'voting-on-foot'. In much the same way as consumers purchase private goods, they can to some degree select a community which provides a pattern of public goods and taxes which is in accord with their tastes. Thus, we can envision a federal system in which communities provide varying levels and combinations of publics goods and in which individuals locate themselves, to some extent at least, according to their fiscal preferences".

50 Antonio Giménez Montero. Federalismo fiscal: teoria y práctica. $2^{\mathrm{a}}$ ed. Valencia: Tirant lo Blanch, 2003, p. 26. 
o bem a ser produzido e a coletividade a ser beneficiada ${ }^{51}$. Exemplo disso é quando as necessidades públicas se apresentam num grau maior do que o volume de serviços públicos postos à disposição de uma determinada coletividade, o que acaba por afastar parcela da população da satisfação dessas necessidades ou, pelo menos, impedir que a fruição do bem se realize de uma forma regular pelos indivíduos ${ }^{52}$.

A existência dessas discrepâncias indica que os entes subnacionais, de mesmo nível ou de níveis diversos, devem agir de forma coordenada para evitar a ineficiência no exercício da função fiscal alocativa. Em algumas circunstâncias, dependendo da característica do bem ou serviço público a ser ofertado, tal coordenação deverá ficar em mãos do poder central.

\subsubsection{Princípio da distribuição centralizada e as funções fiscais distributiva e estabilizadora}

Entende-se pelo princípio da distribuição centralizada que toda atividade que tenha por finalidade a redistribuição de renda deve estar concentrada em mãos da esfera central de governo, uma vez que ela é que terá condições de direcionar com maior eficiência essa ação ${ }^{53}$.

A função fiscal distributiva tem perfeita relação com esse princípio. Diz respeito à capacidade de o governo central poder direcionar suas atitudes de forma a diminuir as desigualdades regionais, de renda e de qualidade de vida da população ${ }^{54}$.

A função distributiva, para alcançar seu desiderato, utiliza-se de alguns meios, tais como os tributos progressivos, a adequada convergência das transferências intergovernamentais e o correto direcionamento das despesas efetuadas pelo Estado ${ }^{55}$.

51 Nesse sentido, Mauro Santos Silva (Teoria do federalismo fiscal: notas sobre as contribuições de Oates, Musgrave, Shah e Ter-Minassian. In: Nova Economia. Belo Horizonte, jan-abr de 2005, p. 122) esclarece que "a combinação entre a presença de economias ou deseconomias de escala e a plena mobilidade de indivíduos agrega uma dificuldade adicional à construção do desenho federativo maximizador, ou seja, a montagem de um tamanho ótimo para cada unidade produtiva nem sempre é compatível com o tamanho das comunidades existentes".

52 Mauro Santos Silva. Teoria do federalismo fiscal: notas sobre as contribuições de Oates, Musgrave, Shah e Ter-Minassian. In: Nova Economia. Belo Horizonte, jan-abr de 2005, p. 122.

53 José Mauricio Conti. Federalismo fiscal e fundos de participação. São Paulo: Editora Juarez de Oliveira, 2001, p. 29. Ver, também, Carlos Alberto Longo e Roberto Luis Troster. Economia do setor público. São Paulo: Atlas, 1993, pp. 148, 150-151.

54 Mauro Santos Silva. Teoria do federalismo fiscal: notas sobre as contribuições de Oates, Musgrave, Shah e Ter-Minassian. In: Nova Economia. Belo Horizonte, jan-abr de 2005, p. 123.

55 Mauro Santos Silva. Teoria do federalismo fiscal: notas sobre as contribuições de Oates, Musgrave, Shah e Ter-Minassian. In: Nova Economia. Belo Horizonte, jan-abr de 2005, pp. 123-124. 
Por intermédio da progressividade tributária é possível ao governo exigir maior aporte daqueles que recebem renda superior aos demais contribuintes. Viabiliza-se essa cobrança pelo aumento progressivo da alíquota do tributo, acréscimo esse diretamente proporcional à renda ${ }^{56}$.

Fácil verificar que esse instrumento não apresentaria reação eficaz caso realizado exclusivamente pelos entes subnacionais. É que a atuação isolada de uma esfera governamental periférica poderia impedir até mesmo o objetivo de uma correta distribuição de riqueza e renda entre os demais entes periféricos da federação ${ }^{57}$, bem como acarretar outras consequências diversas do inicialmente pretendido, tal como a transferência de região das pessoas ou empresas diretamente afetadas pela política governamental aplicada.

Exemplo típico desse último aspecto é quando um determinado governo regional cria impostos altamente progressivos e, ao mesmo tempo, implanta programas sociais de grande interesse para a comunidade. Nessa hipótese, haveria uma transferência dos indivíduos mais ricos dessa região para entes subnacionais que apresentassem uma estrutura tributária que lhes satisfizesse. De outro lado, haveria uma migração de indivíduos mais pobres, de outras regiões, para se beneficiarem da política social implantada no território. Verifica-se, assim, que a mobilidade dos residentes naquela região acaba por inviabilizar a política adotada pelo ente governamental, ou seja, embora se possa afirmar que se alcançou uma distribuição equilibrada no âmbito daquele território, o nível de renda média da população diminuiu, em razão do êxodo dos indivíduos mais ricos ${ }^{58}$. Por esse motivo, a presença do governo central é

56 Mauro Santos Silva. Teoria do federalismo fiscal: notas sobre as contribuições de Oates, Musgrave, Shah e Ter-Minassian. In: Nova Economia. Belo Horizonte, jan-abr de 2005, p. 123.

57 Exemplo dessa situação é apontado por Antonio Giménez Montero (Federalismo fiscal: teoria y práctica. $2^{a}$ ed. Valencia: Tirant lo Blanch, 2003, p. 24) ao afirmar que "outras opiniões a favor da centralização da redistribuição insistem na possibilidade de que as medidas redistributivas subcentrais acarretem efeitos negativos sobre a destinação de recursos, por terem a faculdade de influir ineficientemente nas decisões de localização industrial” (Tradução livre do autor). No original: “(...) otras opiniones a favor de la centralización de la redistribución hacen hincapié en la posibilidad de que las medidas redistributivas subcentrales tengan efectos negativos sobre la asignación de recursos, al poder influir ineficientemente en las decisiones de localización industrial”.

Antonio Giménez Montero. Federalismo fiscal: teoria y práctica. $2^{\text {a }}$ ed. Valencia: Tirant lo Blanch, 2003, p. 24. No original: "En cuanto a los objetivos redistributivos, existe inicialmente una gran coincidencia en que la libre circulación de individuos y mercancías dentro de las fronteras nacionales implica una eficacia casi nula de las políticas redistributivas impulsadas por los gobiernos subcentrales. Si um gobierno regional establece, en el ámbito de su territorio, impuestos fuertemente progresivos y programas sociales económicamente relevantes, los resultados más probables serían un éxodo de los ricos hacia otras regiones y una afluencia de pobres hacia esa región. El resultado final sería una distribución personal más igualitaria dentro de ese territorio, pero con un claro descenso de su renta media por habitante. Es obvio que, en esta argumentación, la movilidad interregional y los elementos que pueden favorecerla o restringirla, es la clave de la discusión acerca de las mayores o menores posibilidades de éxito que pueden tener las políticas redistributivas regionales". 
necessária para proporcionar, em âmbito nacional, a uniformidade de tratamento das questões, evitando, com isso, a mobilidade dos indivíduos das unidades descentralizadas de governo.

No que se refere ao direcionamento das despesas efetuadas pelo Estado, deve ser lembrado que a própria atividade financeira estatal tem a capacidade de transferir recursos do setor privado para o setor público ${ }^{59}$ e, com isso, gerar despesas em prol da coletividade, reestimulando a economia. É possível que a distribuição de renda e riqueza ${ }^{60}$ seja alcançada pela convergência de despesas do Estado às regiões não desenvolvidas, de forma a despertar transformações econômicas e sociais nesses locais. Essa atividade é desempenhada de forma satisfatória pelo governo central, ao passo que a adoção da mesma política pelos entes subnacionais não é capaz de gerar resultado com o mesmo grau de eficiência ${ }^{61}$.

A função distributiva também ocorre por intermédio das transferências intergovernamentais que consistem na remoção de recursos financeiros dos órgãos centrais (União ou estados) para as esferas periféricas de governo (municípios).

59 Aliomar Baleeiro. Uma introdução à ciência das finanças. $16^{a}$ ed. rev. e atual. por Dejalma de Campos. Rio de Janeiro: Forense, 2004, p. 4.

60 Cumpre estabelecer a diferença entre distribuição de renda e de riqueza. Conforme explicita Francisco José Masset Lacombe (Dicionário de administração. São Paulo: Saraiva, 2004, p. 113), a distribuição de riqueza é a "forma como se distribui entre as pessoas físicas de um país a riqueza aí existente", ao passo que a distribuição de renda é a "forma como se distribui entre os agentes econômicos a sua participação nos frutos do processo produtivo". No que se refere à distribuição de renda, Paulo Sandroni (Dicionário de Economia e Administração. In: Os Economistas. São Paulo: Nova Cultural, 1996, p. 359) complementa que é ela a "maneira como se distribui entre os participantes da produção o resultado de sua atividade no processo produtivo. É tradicionalmente estudada do ponto de vista de uma distribuição funcional, isto é, da repartição da renda segundo os fatores de produção: trabalho, capital e recursos naturais. Essa repartição se realiza por meio do pagamento de salários, juros, lucros e da renda da terra".

61 Mauro Santos Silva (Teoria do federalismo fiscal: notas sobre as contribuições de Oates, Musgrave, Shah e Ter-Minassian. In: Nova Economia. Belo Horizonte, jan-abr de 2005, pp. 123-124) explica as nuances da política da despesa em relação à função redistributiva, além de esclarecer os motivos pelos quais essas atividades são mais bem desempenhadas pelas esferas centrais de governo:

"Pela ótica da despesa, os programas redistributivos podem ser operacionalizados por meio de dois mecanismos. Primeiro, na definição da composição da cesta de bens produzidos pelo governo, maior quantidade de bens destinados ao consumo das populações de renda inferior tende a implicar transferências de recursos em forma de produtos e serviços. Segundo, por meio de transferências diretas para as populações de renda mais baixa, de forma a possibilitar que os indivíduos beneficiados possam realizar suas próprias escolhas, ou seja, suas próprias preferências. Essas ações são identificadas como tarefas primordialmente destinadas ao governo central do Estado federativo, por demandarem procedimentos em escala nacional e grau e uniformidade capazes de eliminar possibilidades de deslocamento espacial dos fatores produtivos. Ações dessa natureza, quando adotadas por governos subnacionais, num quadro de ampla mobilidade de fatores, podem ser neutralizadas, segundo Musgrave (1980, p. 540), por dois movimentos:

- o deslocamento de famílias de baixa renda para a jurisdição gestora das transferências;

- a busca por outras jurisdições por parte dos indivíduos e das unidades produtivas, detentoras de alto padrão de renda, à procura de menor custo tributário". 
Além de essas transferências corrigirem externalidades, compensando os entes negativamente afetados, também servem como instrumento de redistribuição de renda e riqueza. Nesse sentido, a intenção é que os recursos financeiros transferidos sejam direcionados - de forma proporcional à necessidade de desenvolvimento - às esferas governamentais de regiões que ainda não possuem nível satisfatório de distribuição de renda. Busca-se estabelecer a igualdade de condições dentro da federação, por intermédio da adequada distribuição de recursos ${ }^{62}$.

As transferências intergovernamentais possuem o importante papel de contrabalançar as desigualdades fiscais existentes entre os diversos entes governamentais, inclusive de mesmo nível. A adoção do mecanismo das transferências permite que o ente subnacional que não possua um nível suficiente de arrecadação de receitas próprias, necessárias à sua subsistência, seja auxiliado pelo ente governamental de grau superior, evitando maiores desequilíbrios dentro da federação ${ }^{63}$.

A realização dessas transferências não teria o mesmo efeito se fosse promovida pelos municípios, por exemplo, ou exclusivamente pelos estados, já que para estabelecer a distribuição de recursos é necessária a visualização geral das desigualdades existentes na federação. Isso porque é justamente por intermédio dessa perspectiva que será possível estabelecer padrões uniformes e critérios seguros para o correto direcionamento de recursos às demais unidades federadas.

Percebe-se, dessa forma, que a função fiscal distributiva possui maior eficiência quando concentrada em mãos do governo central.

É bem verdade, porém, que não se pode negar que os níveis governamentais periféricos das federações possuem condições de praticar, em certo grau, a mencionada função distributiva, principalmente naquelas situações em que há intenção de se adotar uma

62 Sob a perspectiva econômica, Mauro Santos Silva (Teoria do federalismo fiscal: notas sobre as contribuições de Oates, Musgrave, Shah e Ter-Minassian. In: Nova Economia. Belo Horizonte, jan-abr de 2005, p. 131) explica a utilidade das transferências intergovernamentais para a redistribuição de renda e riqueza: "Por fim, temos a 'motivação redistribuição' vinculada a objetivos orientados à redução das diferenças fiscais entre unidades federativas, derivadas dos diferenciais relacionados ao grau de desenvolvimento da atividade econômica, à dimensão da base tributária, aos custos de produção e ao perfil da demanda por bens cuja provisão é de responsabilidade do setor governo".

63 Para uma melhor análise da importância das transferências intergovernamentais na federação, ver Sérgio Prado (Equalização e federalismo fiscal: uma análise comparada: Alemanha, Índia, Canadá, Austrália. Rio de Janeiro: Konrad-Adenauer-Stiftung, 2006, pp. 33-43). Uma excelente explanação a respeito do tema também é encontrada em Wallace Eugene Oates (The role of intergovernmental grants in the U.S. economy with special attention to countercyclical policy. In: Studies in fiscal federalism. Hants: Edward Elgar, 1991, pp. 174-200), que explica o emprego de cada tipo de transferência, bem como sua aplicação no âmbito dos Estados Unidos. 
política regional de distribuição de renda. Nesse sentido, Antonio Giménez Montero afirma que os meios utilizados para essa finalidade são basicamente dois, quais sejam, os "programas de transferências monetárias (dentro dos quais estariam incluídas as propostas de estabelecer pensões assistenciais de âmbito regional)", bem como os "programas destinados a favorecer o crescimento do capital humano de determinados grupos de população"64.

O princípio da distribuição centralizada também guarda estreita relação com a função fiscal estabilizadora, que consiste na "manipulação governamental do gasto público"65, permitindo o controle dos níveis de emprego e de inflação e, consequentemente, assegurando o equilíbrio da economia ${ }^{66}$.

Admite-se, assim, a inversão do desaquecimento da economia de determinada região mediante a convergência de despesas públicas e a diminuição de tributos que afetam aquela localidade. De outro lado, numa situação de extremo aquecimento da economia, tanto a diminuição do gasto público quanto a elevação da carga tributária seriam capazes de reduzir o nível de atividade econômica daquela região ${ }^{67}$.

Da mesma forma que o direcionamento do gasto público permite que o governo exerça o controle sobre a economia, a utilização da dívida pública pode ser útil para o mesmo fim. Dependendo da política pública que se pretende implantar, o governante poderá se valer de empréstimos públicos com o fim de gerar atividades benéficas à economia, inclusive a manutenção do pleno emprego ${ }^{68}$.

64 Federalismo fiscal: teoria y práctica. $2^{\mathrm{a}}$ ed. Valencia: Tirant lo Blanch, 2003, p. 25 (tradução livre do autor). No original: "Em términos generales, tales instrumentos se reducen a dos: programas de transferencias monetarias (dentro de los que se incluirían las propuestas de establecer pensiones asistenciales de ámbito regional) y programas dirigidos a favorecer el crecimiento del capital humano de determinados grupos de población”.

65 Mauro Santos Silva. Teoria do federalismo fiscal: notas sobre as contribuições de Oates, Musgrave, Shah e Ter-Minassian. In: Nova Economia. Belo Horizonte, jan-abr de 2005, p. 125.

66 Richard Abel Musgrave. Teoria das finanças públicas: um estudo de economia governamental. Tradução de Auriphebo Berrance Simões. São Paulo: Atlas; Brasília: INL, 1973, v. 1, pp. 45-48. Título original: The theory of public finance: a study in public economy.

67 Mauro Santos Silva (Teoria do federalismo fiscal: notas sobre as contribuições de Oates, Musgrave, Shah e Ter-Minassian. In: Nova Economia. Belo Horizonte, jan-abr de 2005, p. 125) apud CARVALHO, F. J. C. de et al. Economia monetária e financeira. Rio de Janeiro: Campus, 2000, p. 192.

68 Hugh Dalton (Princípios de finanças públicas. Tradução de Maria de Lourdes Modiano. $4^{\mathrm{a}}$ ed. Rio de Janeiro: FGV, 1980, p. 41. Título original: Principles of public finance) já apontava a utilidade da dívida pública como instrumento de estabilização da economia: “(...) o governo muito pode fazer no sentido de conseguir pleno emprego e estabilizar a vida econômica da coletividade, procurando deliberadamente um superavit ou um deficit, não apenas num ano, mas durante um período de tempo mais longo. A ocorrência de um superavit orçamentário em determinado exercício não significa que seja necessariamente de interesse público a apresentação de um deficit no exercício seguinte. Tudo isso, porém, é política pública sem repercussão correspondente nas finanças individuais". 
Diante dos aspectos acima tratados pode-se depreender que, também na função fiscal estabilizadora, as atividades de alocação do gasto público, de controle da carga tributária e de geração da dívida pública, como formas de provocar o aumento ou a diminuição da atividade econômica de um território, ou a conservação do nível de emprego da população, somente serão eficazes se adotadas por uma esfera governamental central, que possui melhores condições de implementar as transformações necessárias.

A adoção dessas práticas pelos níveis periféricos de governo não costuma apresentar resultados satisfatórios. É que os efeitos da função estabilizadora não ficariam limitados à jurisdição do ente subnacional que a pratica; na verdade, difundir-se-ia por outros entes periféricos, o que acabaria por praticamente revogar as medidas implementadas, que se pretendiam inicialmente como reguladoras da economia nacional ${ }^{69}$.

Ainda que se admita a possibilidade de algumas ações estabilizadoras praticadas pelos entes de níveis periféricos de governo serem capazes de auxiliar no desenvolvimento de certos aspectos econômicos (geração de empregos, ainda que em âmbito regional, por exemplo), o fato é que, ainda assim, tais ações precisariam ser coordenadas por uma esfera maior de governo, como forma de direcioná-las para a finalidade comum da Federação, bem como para evitar discrepâncias importantes entre as demais entidades subnacionais. Essa necessidade de coordenação mostra-se ainda mais clara quando a questão diz respeito ao estabelecimento de políticas macroeconômicas (dívida pública, equilíbrio da balança de pagamentos, políticas monetária e fiscal etc.), situação em que a necessidade de uma diretriz

69 Nesse sentido, Antonio Giménez Montero (Federalismo fiscal: teoria y práctica. $2^{\mathrm{a}}$ ed. Valencia: Tirant lo Blanch, 2003, p. 23) afirma que a função estabilizadora praticada pelos níveis de governo regionais "possuem um elevado grau de abertura. Nessas condições, os instrumentos típicos da política fiscal se mostram muito pouco eficazes pelo fato de que seus efeitos se diluem entre a própria jurisdição e as adjacentes. Além disso, esse elevado grau de abertura faz com que a dívida pública dos governos regionais possua todas as características da dívida 'externa', o que limita ainda mais as possibilidades de utilização dos saldos orçamentários como instrumento da política fiscal” (tradução livre do autor). No original: “(...) la economía de dichos gobiernos tiene un elevado grado de apertura. En esas condiciones, los instrumentos típicos de la política fiscal se muestran muy poco eficaces, debido a que sus efectos se diluyen entre la propia jurisdicción y las colindantes. Por otra parte, ese elevado grado de apertura hace que la deuda pública de los gobiernos regionales posea todas las características de la deuda 'exterior', lo que limita adicionalmente las posibilidades de utilización de los saldos presupuestarios como instrumento de la política fiscal". O mesmo autor (Op. cit., p. 23) aponta mais um motivo que impede uma aplicação eficaz da função estabilizadora no âmbito dos governos regionais: “(...) o controle do volume monetário em circulação, essencial para as possibilidades de êxito da política monetária nacional, é incompatível com a existência de autoridades monetárias subcentrais (de esfera menor que a federal) que podem atuar livremente nesse âmbito, emitindo e retirando dinheiro" (tradução livre do autor). No original: “(...) el control de la masa monetaria em circulación, esencial para lãs posibilidades de éxito de la política monetaria nacional, es incompatible con la existencia de autoridades monetarias subcentrales (de ámbito menor al federal) que puedan actuar independientemente en este ámbito, emitiendo y retirando dinero". 
geral a ser exercida pelo governo central é imprescindível para convergir os esforços das unidades federadas, evitando que suas ações individuais prejudiquem outros entes subnacionais e os objetivos da própria Federação ${ }^{70}$.

\subsubsection{Princípio da compensação fiscal}

Toda vez que a decisão de uma esfera governamental é adotada apenas em seu próprio interesse, desconsiderando o aspecto global do Estado, tal atitude poderá gerar efeitos positivos ou negativos aos demais entes e à própria federação.

Essas consequências são definidas como "externalidades" que, de acordo com Francisco José Masset Lacombe ${ }^{71}$, são “danos ou benefícios causados ou gerados a outrem pela ação de um indivíduo ou organização, sem que o originário da ação pague pelos custos causados ou seja ressarcido pelos benefícios gerados". Wallace Eugene Oates afirma que as externalidades ocorrem "quando as escolhas de um indivíduo ou grupo de indivíduos invadem significativamente o bem-estar de outros, ausente qualquer mecanismo de

70 Marcos Mendes (Federalismo Fiscal. In: ARVATE, Paulo; BIDERMAN, Ciro (org.). Economia do setor público no Brasil. Rio de Janeiro: Elsevier, 2004, pp. 425-426) demonstra o prejuízo que adviria da descentralização de políticas macroeconômicas sem a coordenação do governo central: "Comecemos pelo caso da descentralização extrema. Suponha um país onde há o livre trânsito de pessoas em todo território e o uso de um único padrão monetário. Se não existisse um governo central, com toda a administração pública sendo realizada por governos locais (estados e municípios), seria praticamente impossível para o setor público implementar uma política macroeconômica (busca do pleno emprego, da estabilidade de preços e do equilíbrio de balanço de pagamentos). Qualquer governo local criaria papelmoeda que poderia ser utilizado para comprar bens e serviços em todo o país. Seria mais interessante para cada municipalidade financiar seus gastos emitindo dinheiro do que arrecadando impostos de seus moradores. O resultado seria o descontrole da inflação.

Mesmo que não tivessem controle sobre a política monetária, os governos locais teriam muitas dificuldades para realizar uma política de expansão do gasto público com vistas a estimular o crescimento econômico e o emprego dentro de suas jurisdições. Isso porque o efeito positivo do gasto público sobre a economia não ficaria restrito ao território do estado ou município que adotou tal política. Como há livre-comércio entre esse governo e os demais, parte do impacto positivo beneficiaria as economias dos municípios e estados vizinhos. Sabendo dessa possibilidade, cada governo local evitaria realizar uma política de estímulo ao crescimento econômico, esperando que os governos vizinhos a fizessem, pois, com isso, gozariam dos benefícios sem ter de arcar com os custos gerados por essa política. Esse é o clássico problema do free rider".

71 Dicionário de administração. São Paulo: Saraiva, 2004, p. 144. 
recompensa" ${ }^{92}$. Diz-se que a externalidade é positiva quando ocasiona ganhos aos demais entes; de outro lado, se gera níveis de perda a esses entes, diz-se que é negativa ${ }^{73}$.

Não se pode esquecer, assim, que o fato de um integrante da federação envidar esforços (recursos) para manter e preservar área ambiental pertencente ao seu território acaba por provocar benefícios a outros entes, acarretando-lhes uma externalidade positiva. No mais das vezes, contudo, além de expender recursos para a conservação da área, poderá sofrer

72 The role of intergovernmental grants in the U.S. economy with special attention to countercyclical policy. In: Studies in fiscal federalism. Hants: Edward Elgar, 1991, p. 176 (tradução livre do autor). No original: "An important potential source of distortions in allocative decisions exists whenever the choices of one individual or group of individuals impinge significantly on the welfare of others in the absence of any payment mechanism".

73 Exemplos didáticos de externalidades positivas e negativas no cotidiano são apresentados por Eduardo de Carvalho Andrade (Externalidades. In: ARVATE, Paulo; BIDERAMAN, Ciro (org.). Economia do setor público no Brasil. Rio de Janeiro: Elsevier, 2004, pp. 16-17):

"Por exemplo, ao tirar o carro da garagem e dirigir nas ruas de uma grande cidade como o Rio de Janeiro, o indivíduo impõe um custo aos demais motoristas e à sociedade. Isso porque as ruas ficam mais congestionadas, reduzindo a velocidade dos outros veículos e aumentando a probabilidade de acidentes e a poluição. Da mesma forma, quando um indivíduo acende um cigarro em um ambiente fechado, ele proporciona um desconforto às demais pessoas, que passam a ser fumantes passivos, mesmo contrários às suas vontades. Por sua vez, quando fábricas poluem o rio Amazonas, elas causam prejuízos para os habitantes das regiões ribeirinhas, que utilizam os rios para atender às suas necessidades de abastecimento de água ou em atividades pesqueiras. Ainda, quando vários pescadores atuam numa mesma localidade, uns podem interferir na probabilidade de os outros obterem sucesso ao apanhar peixes. Esses são exemplos de externalidade negativa, quando a ação de um agente econômico afeta negativamente um outro.

Por outro lado, por exemplo, os colegas de classe aprendem quando um aluno faz uma pergunta inteligente e oportuna sobre um determinado tópico discutido pelo professor. Quando uma pessoa planta uma árvore, ela se beneficia com a beleza e a sombra proporcionadas. No entanto, outras pessoas também se beneficiam com um ambiente mais agradável, mais acolhedor, possivelmente menos poluído. Invenções científicas, como a luz elétrica, telefone ou vacina contra a paralisia infantil, beneficiam não somente os seus criadores, mas vários indivíduos em diversas sociedades durante várias gerações. Como um exemplo final, várias lojas e camelôs, que vendem produtos mais populares, estão localizados em uma mesma rua na cidade de São Paulo, a famosa rua 25 de Março. Cada comerciante acaba se beneficiando de estar próximo dos demais, pois os consumidores são atraídos para essa localidade porque podem pesquisar diversos produtos em diferentes lojas de forma bastante conveniente. Esses são exemplos de externalidade positiva, quando a ação de um agente econômico afeta positivamente um outro".

Richard Abel Musgrave (Teoria das finanças públicas: um estudo de economia governamental. Tradução de Auriphebo Berrance Simões. São Paulo: Atlas; Brasília: INL, 1973, v. 1, p. 72. Título original: The theory of public finance: a study in public economy) também expõe exemplos a respeito de externalidades, alertando quanto à complexidade no estabelecimento da forma de sua compensação e à necessidade de arbitramento pelo Estado: "Surgem dificuldades semelhantes quando há necessidade de controles a fim de cobrir divergências entre custos ou benefícios sociais e privados. Pode-se exigir que a fábrica que causa perturbação com sua fumaça aumente a altura de suas chaminés ou que pague os danos, sob a forma de um tributo, que sirva para compensar os que foram prejudicados. No caso de benefícios externos, poder-se-á conceder uma margem pelo atendimento colateral de necessidades sociais, que o mercado não reconhece, por meio de subvenção com origem no orçamento público. Quando a preferência de tempo pública e privada diverge, pode-se pagar um subsídio aos proprietários de recursos naturais, a fim de reduzir sua taxa de exploração. Também é possível pagar subsídios em outras situações em que haja divergência". 
certas restrições para o desenvolvimento de sua região (limitações para instalação de fábricas, por exemplo), em razão, justamente, da necessidade de preservação ambiental ${ }^{74}$.

Exemplos semelhantes de externalidade positiva referem-se àquelas regiões onde são construídas penitenciárias, usinas nucleares ou os chamados "lixões" (depósitos de lixo), os quais, embora produzam benefícios para toda a sociedade, ultrapassando o âmbito daquela esfera governamental, geram repercussão negativa na população local ${ }^{75}$.

De outro lado, o governo de uma região, ao conceder isenções ou incentivos com a finalidade de atrair investimentos, consegue incrementar suas receitas futuras, mas geralmente provoca prejuízo às outras localidades que não possuem condições de oferecer os mesmos benefícios às empresas. Além disso, a outorga de estímulos fiscais gera custos à esfera governamental ofertante, que normalmente os repassa aos contribuintes, muitos deles não diretamente beneficiados pelos resultados produzidos pelos incentivos. Tem-se, dessa forma, exemplos de externalidades negativas, nas quais as ações isoladas de uma esfera governamental - sem considerar o contexto global da federação - são capazes de produzir consequências negativas em relação aos demais entes.

Com a finalidade de equilibrar a federação e anular os desarranjos provocados pelas mencionadas externalidades, impõe-se a necessidade de que sejam devidamente compensados eventuais prejuízos causados a determinado ente federal. Deve ser aplicado, assim, o princípio da compensação fiscal, que tem como finalidade evitar a perda de receita da esfera governamental afetada pela externalidade ${ }^{76}$.

Vale dizer, assim como os melhoramentos proporcionados por certo ente da federação podem ser transferidos a outros (ou à globalidade da federação), nada mais justo que os recursos obtidos pelos entes beneficiados sejam repassados àquele que originou o benefício. Dessa forma, "cada estado é compensado (ou compensa) pelas unidades de benefícios (ou custos) que transfere para outros Estados"

A devida compensação é normalmente viabilizada por intermédio das transferências fiscais intergovernamentais, por meio das quais a esfera central de governo desloca recursos

74 José Mauricio Conti. Federalismo fiscal e fundos de participação. São Paulo: Editora Juarez de Oliveira, 2001, pp. 28-29.

75 Marcos Mendes. Federalismo fiscal. In: ARVATE, Paulo; BIDERMAN, Ciro. Economia do setor público no Brasil. Rio de Janeiro: Elsevier, 2004, pp. 428-429.

76 José Mauricio Conti. Federalismo fiscal e fundos de participação. São Paulo: Editora Juarez de Oliveira, 2001, pp. 28-29.

77 LONGO, Carlos Alberto; TROSTER, Roberto Luis. Economia do setor público. São Paulo: Atlas, 1993, p. 154. 
financeiros a estados e municípios. Pode ocorrer, também, que tais transferências se iniciem nos estados e se direcionem aos municípios.

Como exemplo da utilização da transferência intergovernamental para a correção de externalidades, temos a hipótese de o governo central transferir recursos a um determinado município com a finalidade de este promover a conservação de uma área ambiental, estimulando-o, assim, à preservação de um bem que, embora localizado dentro do nível de governo local, beneficia toda a federação. Vê-se que, diante da externalidade positiva, o governo central atua de forma a compensar os gastos efetuados pelo ente subnacional e, assim, incitando-o a permanecer conservando a área ambiental em benefício de todos ${ }^{78}$.

A prática da transferência fiscal é melhor coordenada pelo nível governamental superior, uma vez que ele é capaz de identificar os pontos de externalidade e promover o devido ajustamento para evitar distorções na federação. Se a atribuição ficasse a cargo dos próprios entes subnacionais (locais e regionais), não haveria condições de estabelecer acordos e ajustes eficazes, mesmo porque cada um dos entes defenderia seus próprios interesses e da população que representa, relegando a segundo plano a preocupação com o desenvolvimento global da federação.

Partindo-se do pressuposto da existência de uma coordenação e estruturação por parte do governo central, nada impede, porém, que ocorram transferências fiscais de um nível

78 O exemplo de transferência intergovernamental, acima tratada, é condicional, com contrapartida e ilimitada, ou seja: condicional porque aquele que efetua a transferência estabelece qual a destinação a ser dada ao valor transferido; ilimitada, uma vez que não há limite de valor para a transferência; e com contrapartida porque é exigido do município que a transferência efetuada seja aplicada de forma proporcional àquele gasto estabelecido. Como ensina Marcos Mendes (Federalismo fiscal. In: ARVATE, Paulo; BIDERMAN, Ciro (org.). Economia do setor público no Brasil. Rio de Janeiro: Elsevier, 2004, p. 438), esse tipo de transferência é utilizado para casos de externalidade positiva. Segundo o autor, "se há um bem público ofertado por um governo local que gera significativos benefícios a não-residentes, então o governo central pode estimular o governo local a ampliar a oferta desse bem, a fim de gerar benefícios não só para os residentes, mas também para não-residentes. A transferência induz o governo local a ampliar a oferta do bem, internalizando os benefícios proporcionados a não-residentes". O mesmo autor (Op. cit., pp. 437-438) dá um exemplo: “A cada real gasto pelo governo local em, por exemplo, controle de poluição, o governo central lhe transferiria, digamos, 25 centavos. Essa modalidade de transferência corresponde, na prática, a um subsídio que barateia o custo de provisão do bem público incentivado". Sob esse aspecto do subsídio e ainda em relação à poluição, Harvey S. Rosen (Public Finance. $7^{\mathrm{a}}$ ed. New York: McGraw-Hill/Irwin, 2005, p. 94) explica que, "supondo-se um número fixo de empresas poluentes, o nível eficiente de produção pode ser obtido ao pagar ao poluidor para não poluir. Embora essa noção em princípio possa parecer peculiar, ela opera muito semelhante ao planejamento tributário. Isso porque um subsídio para não poluir é simplesmente outro método de aumentar o custo de produção efetiva do poluidor" (tradução livre do autor). No original: "Assuming a fixed number of polluting firms, the efficient level of production can be obtained by paying the polluter not to pollute. Although this notion may at first seem peculiar, it works much like the tax scheme. This is because a subsidy for not polluting is simply another method of raising the polluter's effective production cost". 
regional para um nível local ou, até mesmo, transferências entre entidades subnacionais de um mesmo nível, mediante acordo entre esses entes. 


\section{Capítulo 2}

\section{O DESVIO DE RECURSOS E SUA RELAÇÃO COM O FEDERALISMO FISCAL}

2.1 O difícil ajuste entre as funções fiscais no âmbito do federalismo e o problema do desvio de recursos públicos - 2.2 A conduta rent-seeking ou captação do Estado - 2.3 Patrimonialismo, clientelismo e coronelismo: 2.3.1 Origem do patrimonialismo e seu significado atual; 2.3.2 Clientelismo; 2.3.3 Coronelismo - 2.4 Corrupção: 2.4.1 Conceito de corrupção; 2.4.2 A corrupção como risco à República; 2.4.3 A corrupção e a democracia; 2.4.4 A corrupção, o desenvolvimento econômico e social, a ética e o papel do Estado - 2.5 Há relação entre o desvio de recursos públicos e o federalismo fiscal?: 2.5.1 O desvio de recursos públicos e suas consequências para as funções fiscais; 2.5.2 O desvio de recursos públicos e sua relação com o tipo de estrutura do federalismo fiscal.

\subsection{O difícil ajuste entre as funções fiscais no âmbito do federalismo e o problema do desvio de recursos públicos}

Fez-se menção no capítulo anterior à importância e aplicação das três funções fiscais criadas e desenvolvidas por Richard Abel Musgrave. O estudo dessas funções denominadas alocativa, distributiva e estabilizadora - é importante não só para a compreensão do federalismo fiscal, mas também para lançar bases para o desenvolvimento do próprio federalismo.

Importante que se diga que a teoria desenvolvida por Musgrave, do ponto de vista econômico, é normativa, ou seja, estabelece o modelo ideal de como determinada coisa deve ser realizada, ao contrário da teoria positiva, que se preocupa com o estudo dos fatos como eles ocorrem ${ }^{79}$. As diretrizes de seu posicionamento partem do pressuposto de um Estado em

79 Marcos Mendes. Federalismo fiscal. In: ARVATE, Paulo; BIDERMAN, Ciro (org.). Economia do setor público no Brasil. Rio de Janeiro: Elsevier, 2004, p. 429. O mesmo autor expõe quais "são os exemplos da literatura normativa sobre federalismo fiscal: Banco Mundial (2000), Ahmad \& Craig (1997), Burki, Perry y Dillinger (1999), Hemming \& Spahn (1997), McLure Jr. (1997), Ter-Minassian (1997), Shah (1994), Musgrave (1983), Gramlich (1993), Bahl \& Linn (1994), Inman \& Rubinfeld (1996)”. Acrescente-se a essa lista os estudos de Wallace Eugene Oates. 
que estão presentes "padrões eficientes de planejamento fiscal" 80 e visam estabelecer um modelo ideal de federalismo.

A realidade econômica, no entanto, acaba divergindo dos modelos teóriconormativos $^{81}$. Essa diferença ocorre porque as estruturas dos diversos Estados federados existentes, no mais das vezes, não apresentam o grau de planejamento fiscal desejado ou ideal, repercutindo negativamente na correta integração das funções alocativa, distributiva e estabilizadora.

Outra explicação também está na forma pela qual as relações fiscais cooperativas ou competitivas predominam no âmbito da Federação. Essas relações podem se materializar sob as formas horizontal, vertical e mista: a horizontal é aquela que ocorre entre entidades governamentais de mesmo nível; a vertical refere-se às situadas entre uma unidade federativa de maior grau e outra de nível inferior; já a mista envolve relações no âmbito de vários entes federativos de mesmo nível, de nível inferior e de nível superior. Se nessas relações fiscais entre os entes federativos houver a presença de padrões imperfeitos de competitividade e cooperação, todo o arcabouço fiscal da Federação poderá ser prejudicado.

80 Richard Abel Musgrave. Teoria das finanças públicas: um estudo de economia governamental. Tradução de Auriphebo Berrance Simões. São Paulo: Atlas; Brasília: INL, 1973, v. 1, p. 25. Título original: The theory of public finance: a study in public economy.

81 Nesse sentido, importante é a crítica externada por Jonathan Rodden (Federalismo e descentralização em perspectiva comparada: sobre significados e medidas. In: Revista de Sociologia e Política. Curitiba, $\mathrm{n}^{\circ}$ 24, jun. 2005, p. 20. Tradução de Miriam Adelman e Marta Arretche. Título original: Comparative federalism and decentralization: on meaning and measurement) ao alertar para a diferença existente entre a literatura teórica sobre o federalismo fiscal e os aspectos empíricos que envolvem o tema:

“[...] É pouco freqüente que a descentralização fiscal e de políticas envolva um deslocamento de uma quantidade fixa de autoridade ou recursos do governo central para os governos regionais ou locais. Ao contrário, a descentralização geralmente envolve acrescentar novas camadas ou novos recursos e responsabilidades para os níveis inferiores de governo, em um contexto de superposição de esferas de autoridade.

A descentralização política também se acrescenta à natureza complexa e imbricada do governo de múltiplos níveis. Quando a autoridade sobre as políticas e sobre as finanças imbrica-se, não surpreende que a avaliação que os eleitores fazem das autoridades centrais e subnacionais também se inter-relacione. A literatura normativa sobre o federalismo fiscal, assim como as teorias constitucionais norte-americanas sobre o federalismo dual, tem tido efeitos obscurecedores. Muito freqüentemente, economistas e cientistas políticos teorizam sobre descentralização como se ela significasse uma divisão nítida de tarefas, em que o centro só entra para a provisão de bens coletivos nacionais e para corrigir desvios. As noções de federalismo que prevalecem na Ciência Política criam um problema parecido. O federalismo não necessariamente acarreta uma autoridade maior dos governos subnacionais sobre os impostos, gastos ou qualquer outra coisa. O federalismo não implica que o centro e os estados sejam soberanos, cada um protegido contra a interferência do outro. Ao contrário, as federações têm evoluído para contratos incompletos em andamento e pela sua própria natureza estão sob constante renegociação. Na maior parte das federações, o centro depende das províncias para implementar e fazer valer muitas das suas decisões e não pode efetuar mudanças do status quo em algumas áreas sem o consentimento das unidades constituintes". 
Não por acaso é que se admite a existência de conflitos fiscais no âmbito do federalismo. Exemplo claro disso, aliás, é a possibilidade de que a utilização de meios dirigidos ao alcance de uma determinada função fiscal ocasione empecilhos ao atingimento de outras funções, possibilitando a ocorrência de colisão entre as funções fiscais (função alocativa versus função distributiva; função distributiva versus função estabilizadora; função alocativa versus função estabilizadora $)^{82}$.

A existência de todos esses conflitos exige a realização de ajustes (transferências governamentais, por exemplo), a real cooperação entre os entes federados e a coordenação do governo central, tudo com o intuito de harmonizar as divergências e alcançar um padrão de federalismo mais próximo do considerado ótimo. Sem o eficaz funcionamento desses mecanismos de equalização, será a própria Federação quem estará em risco.

Sabe-se, ainda, que a existência de todos os problemas acima mencionados, relativos ao federalismo fiscal, é capaz de gerar outros, principalmente em âmbito mais abrangente, tais como a ausência de crescimento do Estado e a estagnação de políticas públicas.

É nesse contexto que se deve situar a importância de um dos objetos do presente estudo, qual seja, o de perscrutar, sob o ponto de vista fiscal, se a descentralização do Estado sob a forma federativa também é capaz de estimular, encobrir ou evitar o desvio de recursos.

Como os recursos públicos são a própria "matéria-prima" da atividade financeira estatal, poderia, numa primeira análise, até parecer paradoxal tal proposta de exame, uma vez que o federalismo fiscal tem como objetivo, justamente, bem direcionar esses recursos para o alcance das finalidades do Estado. Ocorre que um federalismo fiscal desestruturado não apenas pode ser incapaz de bem exercer suas finalidades precípuas, como também provocar dificuldades ainda maiores, prejudiciais para a manutenção da própria Federação, como é exemplo o descaminho de recursos.

Antes, porém, da análise mais restrita sobre a relação existente entre federalismo fiscal e a questão do desvio de recursos, importante a perfeita delimitação desse último aspecto, de forma a permitir uma melhor compreensão sobre o objeto do presente trabalho, que terá como finalidade última o estudo do caso brasileiro ${ }^{83}$.

82 Mauro Santos Silva. Teoria do federalismo fiscal: notas sobre as contribuições de Oates, Musgrave, Shah e Ter-Minassian. In: Nova Economia. Belo Horizonte, jan-abr de 2005, p. 132.

83 A questão específica envolvendo o federalismo fiscal brasileiro e o desvio de recursos será explicitada nos capítulos seguintes. 
A palavra desvio significa o afastamento de algo do seu direcionamento normal. $\mathrm{O}$ desvio de recursos, então, representa o desencaminhamento do dinheiro público de seu destino programado ou ideal.

Não se tratará, aqui, do desvio de recursos econômicos provocado pela tributação em relação a diferentes aplicações e localidades ${ }^{84}$. De fato, não representa objeto do presente estudo perscrutar, por exemplo, qual seria o imposto adequado a determinada sociedade de forma a evitar desvio de recursos de uma aplicação tributada para outra igualmente tributada, mas menos onerosa ao contribuinte ${ }^{85}$; tampouco se discutirá qual imposto, por exemplo, é capaz de provocar ou de evitar o desvio do contribuinte de uma localidade para outra ${ }^{86}$. Tais questões, embora tenham relação com o federalismo fiscal, não interessam para o objetivo deste trabalho.

84 Estudo interessante a respeito desse aspecto é encontrado no trabalho desenvolvido por Hugh Dalton (Princípios de finanças públicas. Tradução de Maria de Lourdes Modiano. $4^{\mathrm{a}}$ ed. Rio de Janeiro: FGV, 1980, pp. 118-125. Título original: Principles of public finance), ex-Chanceler do Erário Inglês, que examina os efeitos dos desvios econômicos de seus "canais naturais" e a repercussão na produção.

85 No tocante a esse assunto, Hugh Dalton (Princípios de finanças públicas. Tradução de Maria de Lourdes Modiano. $4^{\mathrm{a}}$ ed. Rio de Janeiro: FGV, 1980, pp. 118-119. Título original: Principles of public finance) esclarece: "§ 11. No que diz respeito às diferentes aplicações dos recursos econômicos, há impostos que têm sido defendidos sob a alegação de causarem pouco ou nenhum desvio; estão nesse número os impostos sobre enriquecimentos aleatórios, os impostos sobre o valor de localização da propriedade, os impostos sobre monopolistas (quando não provocam alteração da produção nem do preço de venda), e certos tributos que oneram igualmente todas as aplicações da riqueza.

Em geral, a maneira pela qual ocorre o desvio é a seguinte: uma pessoa que possua ou represente recursos econômicos aplicados em objetos sujeitos a imposto procurará escapar a esse imposto pelo desvio dos mesmos recursos para alguma outra aplicação, na qual não terá imposto a pagar ou terá um imposto menor. Esse desvio lhe será proveitoso, desde que o prejuízo de renda - independentemente do imposto que resulta da mudança de aplicação - seja inferior à vantagem que provém do pagamento de menor imposto. A extensão em que determinado imposto provocará desvios de recursos de uma aplicação tributada para outra, bem como redução na oferta do produto, depende [...] da elasticidade da procura desse produto e da elasticidade da respectiva oferta".

86 O mesmo Hugh Dalton (Princípios de finanças públicas. Tradução de Maria de Lourdes Modiano. $4^{\mathrm{a}}$ ed. Rio de Janeiro: FGV, 1980, p. 122. Título original: Principles of public finance) exemplifica o fenômeno: "Assim, na Inglaterra, entre as duas guerras mundiais, a pesada tributação nas áreas atingidas por um oneroso e prolongado desemprego - distressed areas, como eram chamadas - concorreu, a despeito das reduções de impostos, para arruinar as indústrias existentes naquelas áreas e impedir nelas o advento de novas indústrias. Após a Segunda Guerra Mundial, esta pesada tributação local foi mitigada por uma nova subvenção (Exchequer Equalisation Grant), idealizada durante meu período como Chanceler do Erário. Esse auxílio compensava a deficiência em qualquer área de valor local tributável abaixo da média nacional, enquanto que com minha Lei de Distribuição da Indústria, planejada quando era eu Presidente do Conselho de Comércio (Board of Trade), passaram a ser concedidos incentivos especiais às novas indústrias que se instalassem nas antigas distressed areas - hoje chamadas áreas de desenvolvimento (development areas). Esta lei, promovendo pleno emprego e empregos mais diversificados nas referidas áreas, inclusive novos empregos para mulheres, certamente auxiliou o aumento da produção nacional. Tôda essa benéfica transformação resultou de uma combinação de modificações tributárias, subvenções, contrôles físicos e outras providências administrativas. Foi um benefício, não só por desviar indústrias e outros empregos das mesmas decorrentes para essas áreas, cuja vida social foi reavivada, como por impedir o desvio (ao cabo de longo período de desemprego e degeneração física e espiritual) de homens e mulheres destas áreas para as grandes cidades, cujo crescimento excessivo em quase todos os países do mundo demonstra as nefastas consequiências de navegar-se indolentemente pelos "canais naturais"'. 
A análise proposta restringir-se-á àqueles casos de desvios de recursos em que, de alguma forma, estão presentes atos de clientelismo e de corrupção ou os que, embora não diretamente ligados a esses fatores, acabam por impedir a correta destinação do dinheiro público, prejudicando, em razão disso, a própria sociedade.

Para um completo julgamento a respeito desses pontos, necessária é a delimitação de alguns conceitos tais como o de rent-seeking, patrimonialismo, clientelismo, coronelismo e corrupção. A exata noção desses termos permitirá que se investigue posteriormente, com maior clareza, se é possível estabelecer uma relação entre federalismo fiscal e a questão do desvio de recursos.

\subsection{A conduta rent-seeking ou captação do Estado}

O rent-seeking pode ser traduzido, literalmente, como comportamento "caçador de renda". Os fundamentos dessa teoria econômica foram desenvolvidos por Gordon Tullock, no ano de $1967^{87}$, mas o termo somente foi concebido em 1974, por Anne O. Krueger ${ }^{88}$.

De acordo com Anne O. Krueger, numa economia de mercado, determinadas atividades econômicas sofrem restrições por parte do governo, gerando rendas das mais diversas formas, as quais passam a ser disputadas pelas pessoas; de acordo com a maneira com que essa concorrência pela renda (rent-seeking) é realizada, tal disputa pode ser legal ou ganhar contornos de ilegalidade ${ }^{89}$.

É pelo motivo acima descrito que se afirma representar o termo a conduta daquele que procura conquistar do governo alguma vantagem de mercado. $\mathrm{O}$ caçador de renda (ou rent-seeker) é aquele que se vale de determinados procedimentos para alcançar esses privilégios e, assim, ampliar seus ganhos. Exemplo disso é a hipótese em que grupos de

87 Por meio do artigo "The Welfare Costs of Tariffs, Monopolies, and Theft" (Western Economic Journal, Oxford, v. 5, 1967, pp. 224-232).

88 Por intermédio do artigo "The Political Economy of the Rent-Seeking Society" (The American Economic Review, v. 64, n³, jun. 1974, pp. 291-303).

89 The Political Economy of the Rent-Seeking Society. In: The American Economic Review. v. 64, $\mathrm{n}^{\circ} 3$, jun. 1974, p. 291. No original: "In many market-oriented economies, government restrictions upon economic activity are pervasive facts of life. These restrictions give rise to rents of a variety of forms, and people often compete for the rents. Sometimes, such competition is perfectly legal. In other instances, rent seeking takes other forms, such as bribery, corruption, smuggling, and black markets". Hugo Borsani (Relações entre política e economia: Teoria da Escolha Pública. In: ARVATE, Paulo; BIDERMAN, Ciro (org.). Economia do setor público no Brasil. Rio de Janeiro: Elsevier, 2004, nota de rodapé $\mathrm{n}^{\circ} 22$, p. 118), porém, não concorda que o rent-seeking possa, de alguma forma, envolver atos de corrupção; para ele, o comportamento refere-se apenas a "atividades legais de lobby", embora reconheça que na prática é difícil estabelecer o limite entre um e outro. 
pressão, pertencentes a determinada área econômica, tentam influenciar o governo para que crie ou mantenha monopólio ou outros privilégios de mercado, beneficiando, dessa forma, as empresas pertencentes a esses grupos de pressão. É por esse motivo que o fenômeno também é denominado como captação do Estado, sendo este utilizado para favorecer os grupos de pressão.

Diante dos aspectos acima mencionados, a definição que melhor retrata o comportamento caçador de renda é aquela apresentada por D. G. Hartle $\mathrm{e}^{90}$ :

'Rent seeking' pode ser definido de modo geral como investimentos de recursos reais empreendidos por indivíduos ou grupos de indivíduos (coalizões), com interesses similares, na expectativa de

- obter um aumento (ou evitar uma diminuição) em sua renda como resultado da obtenção (ou obstrução) de mudanças no ordenamento jurídico; ou

- aumentar o privilégio (ou reduzir o custo) de mudanças políticas precoces que criam direitos não exclusivos. ${ }^{91}$

Muitas são as formas de pressionar o governo para a obtenção de vantagens de mercado, maneiras essas que vão desde a atuação de um lobby no âmbito do Poder Legislativo, até expedientes como "a contratação de advogados e outros especialistas, a veiculação de propaganda, a realização de entrevistas e doações em campanhas eleitorais, o financiamento de palestras e viagens aos legisladores e os convites para jantar ou férias"92. Outros expedientes, contudo, apresentam-se ilegais, tais como a prática de subornos e demais atos de corrupção.

O lado pérfido do rent-seeking é a transferência de renda que sua prática acaba ocasionando, uma vez que o custo gerado para exercer pressão em face do governo é repassado à sociedade (no exemplo citado do monopólio, essa transferência poderia ocorrer sob a forma de majoração de tarifas). Além disso, há que se lembrar que o dispêndio efetuado para a busca de vantagens do governo é empregado em uma atividade não

90 The theory of 'rent-seeking': some reflections. In: The Canadian Journal of Economics/Revue canadienne d'Economique, v. 16, $\mathrm{n}^{\circ}$ 4, nov. 1983, Blackwell Publishing/Canadian Economics Association, p. 539.

91 Tradução livre do autor. No original: “'Rent seeking' can be defined comprehensively as investments of real resources undertaken by individuals or groups (coalitions) of individuals with similar interests in the expectation of

- obtaining an increase (avoiding a decrease) in their income wealth as a result of securing (blocking) changes in legal rights; or

- maximizing the benefit (minimizing the cost) of earlier policy changes that created non-exclusive rights".

92 Hugo Borsani (Relações entre política e economia: Teoria da Escolha Pública. In: ARVATE, Paulo; BIDERMAN, Ciro (org.). Economia do setor público no Brasil. Rio de Janeiro: Elsevier, 2004, p. 116). 
produtiva, gerando mais uma vez prejuízo à sociedade e impedindo o crescimento do Estado $^{93}$. Justamente nesse sentido, aliás, é o conceito de Ahmad Seyf a respeito do rentseeking, ao defini-lo "como o excedente gerado no processo de troca com pouca ou nenhuma ligação com o trabalho e o processo de produção" ${ }^{94}$. Em última análise, com o predomínio do comportamento caçador de renda privilegia-se mais o poder de influência exercido pelos grupos de pressão do que a atividade que realmente merece ou necessita de recursos.

É em relação à produção que o rent-seeking diferencia-se do profit-seeking. Como mencionado, o primeiro não tem compromisso com o desenvolvimento da produção; ao contrário, muitas vezes prejudica seu regular funcionamento. Já o profit-seeking (comportamento caçador de lucro) representa a adoção de práticas sempre legais com vistas ao fomento da produção (de bens ou serviços) e à consequente busca do lucro empresarial ${ }^{95}$.

Bem por isso, Hugo Borsani defende que o comportamento caçador de renda não possui aptidão para a geração de novos valores; na verdade, o que ocasiona é mais um custo à sociedade, significando "quase o oposto de criação de renda (rent creation)",96. Associa-se

93 Para um melhor estudo sobre a relação existente entre o comportamento rent-seeking e o prejuízo para o crescimento do país, ver Kevin M. Murphy, Andrei Shleifer e Robert W. Vishny (Why is rent-seeking so costly to growth? In: The American Economic Review, v. 83, $\mathrm{n}^{\circ} 2$, maio de 1993, American Economic Association, pp. 409-414).

94 Corruption and development: a study of conflict. In: Development in Practice, v. 11, ${ }^{\circ}$ 5, nov. 2001, Taylor \& Francis, Ltd., p. 602 (tradução livre do autor). No original: "I define rent seeking as the 'surplus' generated in the exchange process with little or no link with the labour and production processes". Sob esse aspecto, Marcos Fernandes Gonçalves da Silva (Corrupção e produção de bens públicos. In: ARVATE, Paulo; BIDERMAN, Ciro (org.). Economia do setor público no Brasil. Rio de Janeiro: Elsevier, 2004, p. 127) exemplifica: "Segundo as visões sobre a ação dos caçadores de renda, no entanto, há sim uma perda líquida para a sociedade. Ela ocorre na medida em que o monopolista aloca recursos produtivos para atividades ligadas à obtenção e manutenção do seu direito de monopólio: lobbing, propaganda etc. Ou seja, investe em talentos ligados a atividades improdutivas associadas à pressão política".

95 O objetivo e o resultado do profit-seeking são bem explicados por Hugo Borsani (Relações entre política e economia: Teoria da Escolha Pública. In: ARVATE, Paulo; BIDERMAN, Ciro (org.). Economia do setor público no Brasil. Rio de Janeiro: Elsevier, 2004, pp. 116-117): "É importante diferenciar rent seeking de profit seeking. Por essa última expressão, faz-se referência à busca de lucros incrementando a produção de algum bem ou serviço, típica atividade empresarial. Na procura por novas oportunidades que proporcionem um maior lucro, a atividade empresarial profit seeking gera um processo de realocação de recursos que possibilita crescimento econômico. Num mercado livre, o maior lucro obtido por um empresário em determinada atividade atrairá outros para essa área de negócios, e, teoricamente, no correr do tempo, o lucro original tende a diminuir até desaparecer. As taxas de retorno dos recursos investidos nesse processo são estabelecidas de forma competitiva, pela concorrência no mercado. Logicamente, nesse processo, alguns empresários terão taxas positivas e outros, negativas, como resultado de melhores ou piores avaliações. Mas a produção total do bem ou serviço terá aumentado e o preço baixado, beneficiando os consumidores. Em outras palavras, no equilíbrio teórico, o lucro original auferido pelo primeiro empresário profit seeking é distribuído entre os consumidores ou usuários". Relações entre política e economia: Teoria da Escolha Pública. In: ARVATE, Paulo; BIDERMAN, Ciro (org.). Economia do setor público no Brasil. Rio de Janeiro: Elsevier, 2004, p. 117. O autor ainda alerta para os demais custos gerados pelo comportamento rent-seeking: "Ao custo social da atividade rent 
a essa questão, ainda, o fato de que o grupo que exerce a pressão sobre o governo pode não atingir seu intento, representando, com isso, mais dissipação de recursos.

Como já afirmado, a prática desse comportamento não implica, necessariamente, que a corrupção esteja presente. Ocorre que o rent-seeking, inclusive aliado a outros fatores, tais como a ausência de legitimidade do governo, alastra-se por toda a sociedade, incentivando e perpetuando essa conduta e, com isso, criando condições favoráveis ao surgimento da corrupção ${ }^{97}$.

Prova disso é a atuação dos grupos de interesse no âmbito do setor público, os quais penetram na própria estrutura burocrática estatal em busca de privilégios, competindo por "receitas tributárias (subsídios), verbas públicas para governos locais, obras públicas e outras formas de apropriação e transferências de renda", além de contratações oriundas de programas sociais $^{98}$. No mais das vezes, não é raro que esses grupos se valham da corrupção para alcançar seus intentos.

\subsection{Patrimonialismo, clientelismo e coronelismo}

O exame das estruturas do patrimonialismo, do clientelismo e do coronelismo possui importância ímpar para a compreensão do desvio de recursos públicos, mais especificamente em relação à utilização do aparelhamento estatal para fins privados.

Não se pretenderá, aqui, estabelecer qualquer rigor sociológico na classificação desses sistemas, seja porque não representa o objeto do presente trabalho, seja até mesmo em

seeking deve-se agregar o comportamento rent protection (também conhecido como defensive rent seeking), adotado pelos indivíduos que vêem ameaçada sua renda pelos rent seekers, e que se organizam e investem para impedir uma modificação das regras existentes, ou para revogar privilégios já aprovados. O comportamento rent protection (e as suas consequiências na sociedade) é o mesmo do rent seeking. A diferença é que ele existe somente porque existem rent seekers".

97 Ahmad Seyf. Corruption and development: a study of conflict. In: Development in Practice, v. 11, $\mathrm{n}^{\circ}$ 5, nov. 2001, Taylor \& Francis, Ltd., p. 603. No original: "The political structures and ethos in many developing countries appear to have remained the same for decades. This is an additional reason explaining why these structures have little legitimacy in the eyes of those who are being ruled. The immediate outcome of a system that lacks legitimacy is the institutionalisation of lawlessness as the law of the land. This, combined with a weak productive base, serves as a most fruitful ground for the growth of rent-seeking behaviour. Initially, this begins with the state and subsequently trickles down to every layer in society. This universal acceptance of rent seeking perpetuates and encourages more, i.e. regenerating itself; and this, in my view, is the most productive ground for the growth of corruption". 
razão da existência de divergências doutrinárias a respeito da questão ${ }^{99}$. Bem por isso, não será a preocupação delimitar, por exemplo, se o clientelismo e o coronelismo fazem parte da estrutura do patrimonialismo - como parece ser o entendimento de Raymundo Faoro ${ }^{100}$-, mas sim estabelecer como cada um desses elementos se projeta no cenário nacional como justificativa ou contribuição para o desvio de recursos públicos.

\subsubsection{Origem do patrimonialismo e seu significado atual}

Não é possível a compreensão de patrimonialismo, no seu sentido científico, sem antes adentrar no conceito de dominação que, de acordo com Max Weber, "é a probabilidade de encontrar obediência a uma ordem de determinado conteúdo, entre determinadas pessoas indicáveis"101, ou seja, representa a possibilidade de se deparar com o acatamento de "ordens específicas (ou todas) dentro de determinado grupo de pessoas"

Segundo o mesmo autor, os tipos puros de dominação legítima podem ser categorizados como: a) dominação legal, em que se obedece às ordens de um superior segundo os ditames de um determinado estatuto, o qual estabelece a legalidade, impessoalidade, objetividade e vigência dessa obediência; b) dominação carismática, na qual a obediência está baseada no carisma e na confiança em relação ao líder; c) dominação

99 Exemplos dessa divergência podem ser encontrados no interessante trabalho desenvolvido por José Murilo de Carvalho (Mandonismo, Coronelismo, Clientelismo: Uma Discussão Conceitual. In: Dados Revista de Ciências Sociais. Rio de Janeiro, v. 40, n. 2, 1997. Disponível em http://www.scielo.br/scielo.php?script=sci_arttext\&pid=S0011-52581997000200003\&lng=pt\&nrm=iso, acessado em 04.08.2009).

100 De fato, esse é o entendimento do autor (Os donos do poder: formação do patronato político brasileiro. $3^{a}$ ed. rev. São Paulo: Globo, 2001, p. 718): "O coronelismo, o compadrazgo latino-americano, a 'clientela' na Itália e na Sicília participam da estrutura patrimonial. Peças de uma ampla máquina, a visão do partido e do sistema estatal se perde no aproveitamento privado da coisa pública, privatização originada em poderes delegados e confundida pela incapacidade de apropriar o abstrato governo instrumental (Hobbes) das leis. O patrimonialismo pulveriza-se, num localismo isolado, que o retraimento do estamento secular acentua, de modo a converter o agente público num cliente, dentro de uma extensa rede clientelista. $\mathrm{O}$ coronel utiliza seus poderes públicos para fins particulares, mistura, não raro, a organização estatal e seu erário com os bens próprios".

101 Economia e sociedade: fundamentos da sociologia compreensiva. Tradução de Regis Barbosa e Karen Elsabe Barbosa. $4^{a}$ ed. Brasília - São Paulo: Editora Universidade de Brasília - Imprensa Oficial do Estado de São Paulo, 1999, v. 1, p. 33. Título original: Wirtschaft und Gesellschaft: Grundriss der verstehenden Soziologie.

102 Economia e sociedade: fundamentos da sociologia compreensiva. Tradução de Regis Barbosa e Karen Elsabe Barbosa. $4^{a}$ ed. Brasília - São Paulo: Editora Universidade de Brasília - Imprensa Oficial do Estado de São Paulo, 1999, v. 1, p. 139. Título original: Wirtschaft und Gesellschaft: Grundriss der verstehenden Soziologie. 
tradicional, em que a obediência está atrelada à legitimidade da autoridade, nomeada segundo a tradição ${ }^{103}$.

O patrimonialismo estaria situado nessa última forma de dominação, ou seja, a tradicional. Caracteriza-se pela presença de um quadro administrativo e militar sob as ordens pessoais do senhor. O direito passa a ser próprio do senhor (em detrimento do direito dos súditos) e a dominação é praticada em razão desse direito pessoal ${ }^{104}$.

A estrutura do patrimonialismo passa a ser estamental quando a dominação é exercida pelo quadro administrativo - formado por associação ou grupo pertencente à sociedade -, o qual pode se apropriar dos poderes de mando e do resultado econômico dele advindo $^{105}$.

A partir do momento em que o príncipe estrutura seu domínio político fora das bases domésticas, inclusive com a utilização da coação física, é possível afirmar a existência de um Estado patrimonial, modelo esse empregado por muitos dos impérios continentais da Idade Média, alguns deles perdurando até a Idade Moderna ${ }^{106}$.

No patrimonialismo, inclusive no de caráter estamental, não há distinção entre os direitos e rendas senhoriais e os privados ${ }^{107}$. Em consequência, também não existe separação

103 Economia e sociedade: fundamentos da sociologia compreensiva. Tradução de Regis Barbosa e Karen Elsabe Barbosa. $4^{a}$ ed. Brasília - São Paulo: Editora Universidade de Brasília - Imprensa Oficial do Estado de São Paulo, 1999, v. 1, p. 141. Título original: Wirtschaft und Gesellschaft: Grundriss der verstehenden Soziologie.

104 Max Weber. Economia e sociedade: fundamentos da sociologia compreensiva. Tradução de Regis Barbosa e Karen Elsabe Barbosa. $4^{\mathrm{a}}$ ed. Brasília - São Paulo: Editora Universidade de Brasília Imprensa Oficial do Estado de São Paulo, 1999, v. 1, pp. 151-152. Título original: Wirtschaft und Gesellschaft: Grundriss der verstehenden Soziologie.

105 Max Weber. Economia e sociedade: fundamentos da sociologia compreensiva. Tradução de Regis Barbosa e Karen Elsabe Barbosa. 4a ed. Brasília - São Paulo: Editora Universidade de Brasília Imprensa Oficial do Estado de São Paulo, 1999, v. 1, p. 152. Título original: Wirtschaft und Gesellschaft: Grundriss der verstehenden Soziologie.

106 Max Weber. Economia e sociedade: fundamentos da sociologia compreensiva. Tradução de Regis Barbosa e Karen Elsabe Barbosa. Brasília: Editora Universidade de Brasília, 1999, v. 2, p. 240. Título original: Wirtschaft und Gesellschaft: Grundriss der verstehenden Soziologie. O autor ainda afirma que, "originalmente, a administração patrimonial cuidava especificamente das necessidades puramente pessoais, sobretudo privadas, da gestão patrimonial do senhor. A obtenção de um domínio 'político', isto é, do domínio de um senhor sobre outros senhores, não submetidos ao poder doméstico, significa então a agregação ao poder doméstico de outros relações de dominação, diferentes, do ponto de vista sociológico, somente em grau e conteúdo, mas não na estrutura" (Op. cit., p. 240).

107 Max Weber. Economia e sociedade: fundamentos da sociologia compreensiva. Tradução de Regis Barbosa e Karen Elsabe Barbosa. 4a ed. Brasília - São Paulo: Editora Universidade de Brasília Imprensa Oficial do Estado de São Paulo, 1999, v. 1, p. 155. Título original: Wirtschaft und Gesellschaft: Grundriss der verstehenden Soziologie. 
entre o patrimônio público e o privado, funcionando o aparato estatal, aliás, como instrumento da vontade do senhorio ${ }^{108}$.

O surgimento do patrimonialismo no Brasil deve ser encarado tendo-se em vista a história de Portugal, que a partir do século XIV desenvolveu um capitalismo nitidamente calcado na burguesia mercantil. Sob essa estrutura, o rei centralizava todas as operações comerciais, administrando os negócios como sua própria empresa ${ }^{109}$; vale dizer, era ele quem comandava o processo produtivo ${ }^{110}$. Ocorre, porém, que todo o arcabouço estamental tornouse dependente dessa estrutura ${ }^{111}$, impedindo sua emancipação, fato que poderia ser contornado se Portugal não tivesse falhado na implantação do capitalismo industrial ${ }^{12}$.

108 Nesse sentido, Max Weber (Economia e sociedade: fundamentos da sociologia compreensiva. Tradução de Regis Barbosa e Karen Elsabe Barbosa. Brasília: Editora Universidade de Brasília, 1999, v. 2, p. 263. Título original: Wirtschaft und Gesellschaft: Grundriss der verstehenden Soziologie) esclarece que o “complexo patrimonial político não conhece nem o conceito de 'competência' nem o de 'autoridade administrativa' no sentido atual das palavras, e isto tanto menos quanto maior a apropriação. A separação de assuntos oficiais e privados, patrimônio oficial e privado e a correspondente autoridade senhorial dos funcionários encontra-se apenas razoavelmente realizada no tipo arbitrário, diminuindo com o avanço do sistema de prebendas e apropriação. (...)

De modo geral falta ao cargo baseado em relações de subordinação puramente pessoais a idéia do dever oficial objetivo. O que existe neste sentido desaparece completamente quando se trata o cargo como prebenda ou bem apropriado. O exercício do poder é em primeiro lugar um direito senhorial pessoal do funcionário; fora dos limites fixos da tradição sagrada decide também ele, como o senhor, de caso a caso, isto é, segundo arbítrio e graça pessoal. Por conseguinte, o Estado patrimonial é, na área da formação do direito, o representante típico da coexistência de uma vinculação inquebrantável à tradição, por um lado, e, por outro, de uma substituição do domínio de regras racionais pela 'justiça de gabinete' do senhor e de seus funcionários. Em vez de 'objetividade' burocrática e do ideal, baseado na vigência abstrata de um direito igual e objetivo, da administração 'sem considerações pessoais', rege o princípio oposto. Simplesmente tudo baseia-se expressamente em 'considerações pessoais', isto é, na avaliação do solicitante concreto e de seu pedido concreto e em relações, atos de graça, promessas e privilégios puramente pessoais".

109 Raymundo Faoro. Os donos do poder: formação do patronato político brasileiro. $3^{\mathrm{a}}$ ed. rev. São Paulo: Globo, 2001, p. 40.

110 A respeito desse aspecto, Simon Schwartzman (Empresários y politica en el proceso de industrializacion. Argentina, Brasil, Austrália. Tradução de Mario R. dos Santos. In: Desarrollo Económico, Instituto de Desarrollo Económico y Social, v. 13, n. 49, abr-jun 1973, p. 87) afirma que "a existência da dominação patrimonial depende do controle do processo produtivo da sociedade por parte do senhor e de seu séquito" (tradução livre do autor). No original: "La existencia de la dominación patrimonial depende del control del proceso productivo de la sociedad por parte del senior y de su entourage".

111 Raymundo Faoro (Os donos do poder: formação do patronato político brasileiro. $3^{\mathrm{a}}$ ed. rev. São Paulo: Globo, 2001, pp. 38-40) explica essa dependência: “(...) O sistema patrimonial, ao contrário dos direitos, privilégios e obrigações fixamente determinados do feudalismo, prende os servidores numa rede patriarcal, na qual eles representam a extensão da casa do soberano. Mais um passo, e a categoria dos auxiliares do príncipe comporá uma nobreza própria, ao lado e, muitas vezes, superior à nobreza territorial. Outro passo ainda e os legistas, doutores e letrados, conservando os fumos aristocráticos, serão sepultados na vala comum dos funcionários, onde a vontade do soberano os ressuscita para as grandezas ou lhes vota o esquecimento aniquilador.

[...] Nenhuma exploração industrial e comercial está isenta de seu controle [do príncipe] - guarda, todavia, para seu comando imediato os setores mais lucrativos, que concede, privilegia e autoriza à burguesia nascente, presa, desde o berço, às rédeas douradas da Coroa".

No mesmo sentido é o entendimento de Simon Schwartzman (Empresários y politica en el proceso de industrializacion. Argentina, Brasil, Austrália. Tradução de Mario R. dos Santos. In: Desarrollo 


\author{
Outras implicações dessa problemática são bem expostas por Renato Janine \\ Ribeiro $^{113}$, ao afirmar:
}

Contudo, esse avanço português [capitalismo mercantil], que no final da Idade Média serviu ao rei contra a nobreza, acabou esterilizando a economia e a sociedade - na incapacidade de definir o indivíduo como detentor de liberdade, o capital como produtor de riquezas na manufatura e o Estado como uma esfera pública a distinguir-se do rei e de seus próximos. Isso resultou numa hipertrofia do Estado e do estamento burocrático ligado a ele, em prejuízo de uma organização mais autônoma da sociedade, como a que houve na Inglaterra e em suas colônias norte-americanas.

A dificuldade enfrentada por Portugal repercutiu em suas colônias, inclusive no

Brasil, que herdou uma estrutura política e administrativa que não estabelecia uma separação clara entre o público e o privado.

Além disso, a configuração inicial da sociedade brasileira, dividida por estamentos e não por classes $^{114}$, propiciava que a administração da coisa pública estivesse sempre em

Económico, Instituto de Desarrollo Económico y Social, v. 13, n. 49, abr-jun 1973, p. 78), ao afirmar: "Existe uma importante diferenta entre uma nação tal como Austrália, que foi criada como conseqüência da expansão da economia britânica, e as 'nações novas', tais como Brasil e Argentina, nas quais o impulso econômico externo foi estabelecido dentro de um contexto preexistente de patrimonialismo político e de dependência das atividades produtivas do estado patrimonial. Nessas 'antigas novas nações', a política não chegou a estar em mãos dos novos grupos econômicos, mas os antigos setores hegemônicos tiveram que mudar de estilo e abrir o sistema político a novas formas de participação" (tradução livre do autor). No original: "Existe una importante diferencia entre una nación tal como Australia, que fue creada como consecuencia de la expansión de la economía británica, y 'naciones nuevas' tales como Brasil o la Argentina, donde el impulso económico externo fue establecido dentro de un contexto preexistente de patrimonialismo político y de dependencia de las actividades productivas del estado patrimonial. En estas 'antiguas nuevas naciones', la política no llegó a estar en manos de los nuevos grupos económicos, aún si los antiguos sectores hegemónicos tuvieron que cambiar de estilo y abrir el sistema político a nuevas formas de participación".

112 A respeito dessa questão, Raymundo Faoro (Os donos do poder: formação do patronato político brasileiro. $3^{\text {a }}$ ed. rev. São Paulo: Globo, 2001, pp. 40-41) leva ao entendimento de que a falta de contato de Portugal com a estrutura do feudalismo gerou obstáculo à sua passagem para o capitalismo industrial: "Quando o capitalismo brotar, quebrando com violência a casta exterior do feudalismo, que o prepara no artesanato, não encontrará, no patrimonialismo, as condições propícias de desenvolvimento. O trânsito, a compra e venda, o transporte, o financiamento ensejarão o gigantismo dos órgãos de troca, com o precário enriquecimento da burguesia, reduzida ao papel de intermediária entre as outras nações. A atividade industrial, quando emerge, decorre de estímulos, favores, privilégios, sem que a empresa individual, baseada racionalmente no cálculo, incólume às intervenções governamentais, ganhe incremento autônomo. Comanda-a um impulso comercial e uma finalidade especulativa, alheadores das liberdades econômicas, sobre as quais assenta a revolução industrial. Daí se geram consequiências econômicas e efeitos políticos, que se prolongam no século XX, nos nossos dias. (...) A Península Ibérica, com suas florações coloniais, os demais países desprovidos de raízes feudais, inclusive os do mundo antigo, não conheceram as relações capitalistas, na sua expressão industrial, íntegra".

113 A República. $2^{\mathrm{a}}$ ed. São Paulo: Publifolha, 2008, p. 38.

114 De acordo com Renato Janine Ribeiro (A República. 2a ed. São Paulo: Publifolha, 2008, p. 39), “classe remete a uma diferenciação promovida pelo capital entre as categorias da sociedade. Já estamentos são ordens ou categorias sociais mais fechadas, definidas pelo prestígio social e pela honra mais que pelo lucro ou pelo capital". 
mãos da elite estamental, que se utilizava de recursos públicos para a satisfação de suas necessidades particulares.

Privilegiava-se, assim, não a criação de um aparelhamento burocrático ideal - nos dizeres de Raymundo Faoro, "a camada profissional que assegura o funcionamento do

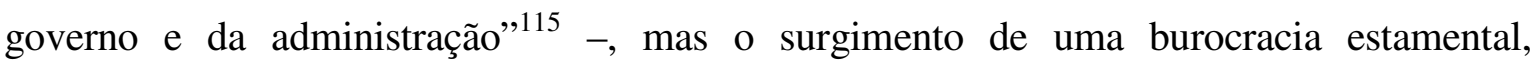
representada por uma camada acima da sociedade, "a qual impera, rege e governa, em nome próprio, num círculo impermeável de comando"116.

Esse modelo patrimonialista, embora tenha fortemente perdurado no Brasil até a República Velha (1889 a 1930), ainda influencia e produz consequências no país, principalmente quando se observa o comportamento de políticos que se utilizam do aparato estatal para o atendimento de interesses particulares, inclusive impedindo a regular implantação ou andamento das políticas públicas ${ }^{117}$.

Bem por isso, conforme lembra Renato Janine Ribeiro, no cenário atual utiliza-se o termo patrimonialista como "o modo pelo qual governantes de qualquer nível, do presidente ao simples funcionário, se valem do bem comum para sua vantagem privada" ${ }^{, 18}$. De fato, embora a origem da expressão representasse apenas a apropriação da coisa pública pelo soberano, pode-se afirmar que, nos dias atuais, o mesmo termo pode ser empregado nas situações em que há a utilização do aparelhamento estatal para a busca de benefícios

115 Os donos do poder: formação do patronato político brasileiro. $3^{\mathrm{a}}$ ed. rev. São Paulo: Globo, 2001, p. 825.

116 Raymundo Faoro (Os donos do poder: formação do patronato político brasileiro. $3^{\mathrm{a}}$ ed. rev. São Paulo: Globo, 2001, p. 824). Acrescenta o autor: "Há a burocracia, expressão formal do domínio racional, própria ao Estado e à empresa modernos, e o estamento burocrático, que nasce do patrimonialismo e se perpetua noutro tipo social, capaz de absorver e adotar as técnicas deste, como meras técnicas. Daí seu caráter não transitório" (Op. cit., p. 825).

117 No tocante às políticas públicas, interessante é a observação de Erasto Fortes Mendonça (Estado patrimonial e gestão democrática do ensino público no Brasil. In: Educação \& Sociedade. Campinas, v. 22, n. 75, ano XXII, ago. 2001, p. 97, disponível em http://www.scielo.br/scielo.php?script=sci_arttext\&pid=S0101-73302001000200007\&lng=pt\&nrm=iso, acessado em 16.09.2009): "Esta caracterização permite compreender um tipo de burocratização pertencente ao Estado não moderno, nascida do patrimonialismo, por ele alimentado e dele alimentador, uma vez que se amolda às mudanças, adotando, tão-somente, aparência de modernidade. $\mathrm{O}$ ajustamento às técnicas modernas, porém, não aproxima o estamento burocrático da burocracia como expressão mais pura da dominação legal e aparelho administrativo que assegura o funcionamento do governo.

É essa maneira autocrática e autoritária de funcionamento do Estado, característica do governo estamental, que permite que as políticas públicas, de que a gestão democrática do ensino público é apenas um exemplo, sejam constantemente alteradas, ao sabor das conveniências políticas. O governante dita à sociedade a sua vontade pessoal como se estatal fosse, numa versão adaptada e moderna do coronelismo, elemento que participa da estrutura patrimonial e que transforma o governante no dono do governo".

118 A República. $2^{\mathrm{a}}$ ed. São Paulo: Publifolha, 2008, pp. 38-39. Adverte o mesmo autor, porém, que a utilização desse sentido somente é cabível "por analogia - ou como consequiência de um processo que, no seu centro, não era a genérica e vaga utilização por qualquer um da coisa pública, mas sua apropriação pelo príncipe, pelo governante, pelo soberano". 
próprios. A construção deliberada de obras públicas (ou outras melhorias), próximas à residência do próprio prefeito do município, pode representar, por exemplo, a adoção de uma prática patrimonialista, uma vez que o dinheiro público é utilizado para o favorecimento pessoal do governante ${ }^{119}$.

É justamente nesse sentido, presente ou não a corrupção em seu bojo, que será empregada a expressão no presente trabalho, visto constituir também um dos modos pelos quais ocorre o desvio de recursos públicos no país.

\subsubsection{Clientelismo}

O termo clientelismo tem sua origem no fenômeno denominado "clientela", surgido em Roma, e que compreendia a relação existente entre o patronus e o cliente. O patronus era o indivíduo que gozava de uma posição privilegiada na sociedade romana e que protegia seus clientes por intermédio de favores, tais como entrega de terras para exploração e defesa em juízo. Os clientes, por sua vez, normalmente representados por imigrantes estrangeiros ou escravos libertos, reconheciam o auxílio subordinando-se às ordens do patronus, inclusive defendendo-o quando necessário ${ }^{120}$.

119 Erasto Fortes Mendonça (Estado patrimonial e gestão democrática do ensino público no Brasil. In: Educação \& Sociedade. Campinas, v. 22, n. 75, ano XXII, ago. 2001, p. 97, disponível em http://www.scielo.br/scielo.php?script=sci_arttext\&pid=S0101-73302001000200007\&lng=pt\&nrm=iso, acessado em 16.09.2009) apresenta outro exemplo em que o patrimonialismo se destaca, aliado ao clientelismo: "Para o político profissional, ter o diretor escolar como aliado político é ter a possibilidade de deter indiretamente o controle de uma instituição pública que atende diretamente parte significativa da população. Para o diretor, gozar da confiança da liderança política é ter a possibilidade de usufruir do cargo público. Estabelecem-se, desta maneira, as condições de troca de favores que caracterizam o patrimonialismo na ocupação do emprego público. Essa forma de provimento, que denominei indicação, baseia-se na confiança pessoal e política dos padrinhos e não na capacidade própria dos indicados, ficando distante da ordenação impessoal que caracteriza a administração burocrática. A exoneração segue, nesse sentido, a mesma lógica. Na medida em que o beneficiado com o cargo perde a confiança política do padrinho, a exoneração é acionada como conseqüência natural, como o despojamento de um privilégio".

120 Alfio Mastropaolo. Clientelismo. In: BOBBIO, Norberto; MATTEUCCI, Nicola; PASQUINO, Gianfranco. Dicionário de política. $12^{\mathrm{a}}$ ed. Tradução de Carmen C. Varriale et al. Coord. da tradução: João Ferreira. Brasília: Editora Universidade de Brasília, 2002, v. 1, p. 177. A vinculação existente entre clientes e patronus sofria influência da comunidade familiar romana, à época. Essa relação é bem explicitada por Fustel de Coulanges (A cidade antiga: estudos sobre o culto, o direito, as instituições da Grécia e de Roma. Tradução de Jonas Camargo Leite e Eduardo Fonseca. São Paulo: Hemus, 1975, pp. 188-189. Título original: La cité antique: étude sur le culte, le droit, les institutions de la Grece et de Rome) ao comentar: "[...] De geração em geração, não havia senão um chefe de família: presidia ao sacrifício, dizia a oração, julgava e governava. Só a esse homem, a princípio, partencia o título de pater, porque essa palavra, designando o poder e não a paternidade, podia aplicar-se ao chefe da família. Seus filhos, seus irmãos e seus servos, todos o chamavam assim. [...]

Depois, essa família tem servos que não a abandonam, servos hereditariamente vinculados à família e sobre os quais o pater ou patrono exerce sua tríplice autoridade de mestre, de magistrado e de sacerdote. 
Essa relação de dependência política e econômica ${ }^{121}$, nos dias atuais, ocorre mediante a atuação de políticos, que chegam até a barganhar com a coisa pública para a obtenção de apoio eleitoral. Tal prática,

à semelhança do Clientelismo tradicional, tem, por resultado, não uma forma de consenso institucionalizado, mas uma rede de fidelidades pessoais que passa, quer pelo uso pessoal por parte da classe política, dos recursos estatais, quer, partindo destes, em termos mais mediatos, pela apropriação de recursos 'civis' autônomos ${ }^{122}$.

Segundo S. N. Eisenstadt e Louis Roniger, as principais características do clientelismo podem ser assim descritas: a) a relação patrão-cliente dá-se em termos difusos e particularizados; b) acordo baseado numa combinação indivisível da troca de recursos econômicos e políticos por promessas de lealdade e solidariedade; c) relação caracterizada por forte traço de comprometimento, incondicionalidade e, em termos gerais, solidariedade entre patrão e cliente; d) o vínculo clientelista não ocorre em bases legais ou contratuais, mas é objeto de um acordo informal entre os agentes; de qualquer forma, essa associação é, em princípio, voluntária, podendo cada uma das partes dela se desvincular a qualquer momento;

Davam-lhes nomes diferentes, segundo as regiões, embora os mais comumente conhecidos sejam os de clientes e tetas.

Eis mais uma vez uma classe inferior. O cliente está abaixo não somente do chefe supremo da família, mas ainda dos ramos mais novos. Entre eles há essa diferença: o membro de um ramo mais novo, remontando a série dos antepassados, chega sempre a um pater, isto é, a um chefe de família, um daqueles antepassados divinos, que a família invoca em suas orações. E, como descende do pater, chamam-no, em latim, patricius. O filho do cliente, pelo contrário, por mais alto que ascenda em sua genealogia, não alcançará senão algum cliente ou escravo. Não existe nenhum pater entre seus antepassados. Daí lhe resulta esse estado de inferioridade, de que nada o pode livrar".

121 A subordinação política e econômica entre o patronus e os clientes é também exemplificada por Fustel de Coulanges (A cidade antiga: estudos sobre o culto, o direito, as instituições da Grécia e de Roma. Tradução de Jonas Camargo Leite e Eduardo Fonseca. São Paulo: Hemus, 1975, pp. 189-190. Título original: La cité antique: étude sur le culte, le droit, les institutions de la Grece et de Rome): "A distinção entre essas duas classes de homens é manifesta, no que concerne a interesses materiais. A propriedade da família pertence exclusivamente ao chefe, que, aliás, partilha sua fruição com os ramos mais novos da família e até mesmo com os clientes. Mas, enquanto o ramo mais novo tem, pelo menos, um direito eventual sobre a propriedade, caso o ramo mais velho venha a extinguir-se, o cliente, pelo contrário, jamais poderá vir a ser proprietário. A terra que cultiva, só a possui em depósito e, quando o cliente morre, volta às mãos do patrono; o direito romano de épocas posteriores conservou vestígios dessa antiga regra no que se chamou jus applicationis. O próprio dinheiro do cliente não lhe pertence, mas ao seu patrono, que, sendo seu verdadeiro proprietário, pode dele apoderar-se para as suas necessidades particulares. Em virtude dessa regra antiga, o direito romano mandou o cliente dotar a filha do patrono, pagar a multa devida por este, fornecer-lhe resgate ou contribuir para os encargos das várias magistraturas.

[...] Assim, mesmo antes de se sair do estado de família, já existia uma distinção de classes; a antiga religião doméstica se encarregara de estabelecer os respectivos graus. Quando, a seguir, a cidade se formou, nada se alterou na organização interior da família. (...) A distinção das classes, surgida na família, continuou portanto com a cidade".

122 Alfio Mastropaolo. Clientelismo. In: BOBBIO, Norberto; MATTEUCCI, Nicola; PASQUINO, Gianfranco. Dicionário de política. $12^{\mathrm{a}}$ ed. Tradução de Carmen C. Varriale et al. Coord. da tradução: João Ferreira. Brasília: Editora Universidade de Brasília, 2002, v. 1, pp. 177-178. 
e) a relação clientelar ocorre de forma vertical, entre indivíduos ou redes de indivíduos, e não entre grupos corporativos organizados; f) o patrão, comparado ao cliente, exerce um poder social de maior amplitude, existindo clara diferença de poder entre ambos ${ }^{123}$.

Depreende-se, assim, que o clientelismo envolve a outorga de favores em troca de apoio político ou de votos dirigidos para o partido ou para o próprio político. Pressupõe uma relação que nunca ocorre em bases paritárias. Essa característica se justifica porque há a presença da subordinação, representada pela dominação exercida pelo patrão no tocante aos seus clientes ${ }^{124}$. Esses clientes, por sua vez, somente dão apoio ao patrão porque pretendem, no futuro, a obtenção de algum benefício ${ }^{125}$.

123 Patron-Client Relations as a Model of Structuring Social Exchange. In: Comparative Studies in Society and History, v. 22, $\mathrm{n}^{\circ}$ 1, jan. 1980, Cambridge University Press, pp. 49-50. No original: "We shall start with the identification, on the basis of the growing and voluminous literature on the subject, of the core characteristics of patron-client relations and the types of social interaction they involve, especially in those societies or sectors thereof in which patron-client relations are interwoven with the central mode of the structuring of the flow of resources. The most important of these core analytical characteristics are given below. a) Patron-client relations are usually particularistic and diffuse. b) The interaction on which they are based is characterized by the simultaneous exchange of different types of resources, above all instrumental economic, as well as political ones (support, loyalty, votes, protection) on the one hand and promises of solidarity and loyalty on the other. c) The exchange of these resources is usually effected by a 'package-deal,' i.e., neither resource can be exchanged separately but only in a combination that includes both types. d) Ideally, a strong element of unconditionality and of long-range credit and obligations is built into these relations. e) As a corollary, there is a strong element of solidarity in these relations - an element often couched in terms of interpersonal loyalty and attachment between patrons and clients - even though these relations may often be ambivalent. The element of solidarity may be strong, as in the restricted primary relationship of the classical type of patronage, or, as in many of the more modern political machines, very weak, but to some degree it is to be found in all of them. Solidarity is often closely related to conceptions of personal identity, especially of personal honor and obligations, and it is also evident that some, even if ambivalent, personal 'spiri-tual' attachment may exist between patron and clients. f) At the same time, the relations established are not fully legal or contractual; they are often opposed to the official laws of the country and are based more on informal although tightly binding - understandings. g) Despite their seemingly binding, long-range and, in their ideal portrayal almost life-long endurance, patron-client relations are entered into voluntarily, at least in principle, and can, officially at least, be abandoned voluntarily. h) These relations are undertaken between individuals or networks of individuals in a vertical fashion (the simplest kind is a strong dyadic one) rather than between organized corporate groups. They seem to undermine the horizontal group organization and solidarity of both clients and patrons, but especially of clients. i) Last and not least, patron-client relations are based on very strong elements of inequality and of differences in power. Even at this stage of our discussion it should be evident that the crucial element of this inequality is the monopolization by the patrons of certain positions that are of vital importance for the clients; especially, as we shall see in greater detail later, of the access to the means of production, major markets and centers of the society".

124 Nesse sentido é o ensinamento de Ramon Maiz (Jama, caleta y camello: la corrupcion como mecanismo de autorrefuerzo del clientelismo político. In: Revista Mexicana de Sociologia, v. $65, \mathrm{n}^{\circ} 1$, jan-mar de 2003, Universidad Nacional Autônoma de México, p. 13) ao explicitar: "Em concreto, os estudiosos do clientelismo assinalam, reiteradamente, que a rede clientelar não apenas implica uma relação de intercâmbio de votos por favores, recíproco e mutuamente proveitoso, mas também que essa relação resulta constitutivamente desigual e assimétrica, isto é, que implica relações de subordinação e, portanto, de dominação, do patrão sobre os clientes" (tradução livre do autor). No original: "En concreto, los estudiosos del clientelismo han señalado reiteradamente que la red clientelar no sólo implica una relación de intercambio de votos por favores, recíproco y mutuamente beneficioso, sino adem[as, que 
Com essas características, nítida a constatação de que o vínculo político clientelar difere-se do vínculo político programático, o qual se consubstancia na distribuição de "benefícios e custos entre os eleitores mediante políticas públicas e critérios objetivos e universalistas, sejam esses eleitores votantes ou não do partido"126.

De fato, no vínculo político programático, o contato entre o político (ou seu partido) e o eleitorado ocorre de forma universal, funcionando o programa de governo como único elo possível entre eles. Nesse caso, por intermédio do voto, o eleitor pode aceitar ou não o pacote de políticas públicas ofertado pelo candidato em seu programa político ${ }^{127}$. Já no vínculo político clientelar ocorre o inverso, uma vez que o contato entre o político e o eleitor ocorre de maneira direta, por intermédio da distribuição de recursos para atender a fins particulares do eleitorado. Não há, nessa hipótese, nenhuma ligação com a posição

esta relación resulta constitutivamente desigual y asimétrica, esto es, que implica relaciones de subordinación y por lo tanto de dominación del patrón sobre los clientes".

125 Sharon Kettering (The Historical Development of Political Clientelism. In: Journal of Interdisciplinary History, v. 18, $\mathrm{n}^{\circ} 3,1988$, p. 425) esclarece que o patrão age como protetor de seus clientes, oferecendo vantagens de variados tipos. O cliente, por sua vez, busca retribuir essas benesses com sua lealdade ao patrono. Por esse motivo é que se afirma que o "patrono é o superior e o cliente é o inferior num relacionamento desigual, vertical e recíproco" (tradução livre do autor). No original: "A patron-client relationship, on the one hand, is a personal, direct exchange in which a patron uses patronage resources he himself owns or controls on behalf of his clients: he assists and protects his clients, giving them material benefits, opportunities for career advancement, and protection from the demands of others. Clientage, on the other hand, is the loyalty and service that a client owes a patron in return for his protection and ad-vancement: a patron is the superior and a client the inferior in an unequal, vertical, and reciprocal relationship".

126 Ramon Maiz. Jama, caleta y camello: la corrupcion como mecanismo de autorrefuerzo del clientelismo político. In: Revista Mexicana de Sociologia, v. 65, $\mathrm{n}^{\circ}$ 1, jan-mar de 2003, Universidad Nacional Autônoma de México, p. 7 (tradução livre do autor). No original: "Nuestro acercamiento al fenómeno del clientelismo partirá de la especificidad del vínculo político clientelar (clientelistic linkage), como tipo ideal caracterizado por el intercambio de favores, de beneficios materiales, por votos al político o partido que los suministra, frente al vínculo político programático (programmatic linkage), que distribuye beneficios y costos entre los electores mediante políticas públicas y critérios objetivos y universalistas, sean o no votantes del partido".

127 Quanto ao vínculo político programático, Ramon Maiz (Jama, caleta y camello: la corrupcion como mecanismo de autorrefuerzo del clientelismo político. In: Revista Mexicana de Sociologia, v. 65, $\mathrm{n}^{\circ} 1$, jan-mar de 2003, Universidad Nacional Autônoma de México, p. 9) afirma que, "por sua vez, os votantes recebem o impacto das políticas públicas com critério universalista e codificado, com independência se votam ou não no partido no governo. O intercâmbio é indireto precisamente por estar mediado pelo programa ou, mais precisamente, pelos princípios programáticos sintetizados que visualizam de modo simples, esquemático e com economia de informação ante o eleitorado, a posição do partido" (tradução livre do autor). No original: "A su vez, los votantes reciben el impacto de las políticas públicas con criterio universalista y codificado, con independencia de si votan o no por el partido en el gobierno. El intercambio es indirecto precisamente por estar mediado por el programa o, más exactamente, por los principios programáticos sintetizados que visualizan de modo sencillo, esquemático y con economia de información ante el electorado la ubicación del partido". 
programática do político, mas sim com o que este oferece de vantagem material para a obtenção do voto do eleitor ${ }^{128}$.

A relação clientelar ocorre, também, com base na confiança estabelecida entre os dois polos. Da forma como se apresenta, contudo, impede que os clientes se mobilizem politicamente em defesa de seus próprios interesses. Isso é explicado porque a confiança no patrão não implica afirmar que exista confiança entre os clientes; ao contrário, por perseguirem o mesmo objetivo, o que existe entre eles é uma desconfiança difundida entre todos, impedindo sua mobilização para reivindicações de caráter comum ${ }^{129}$.

Já no vínculo programático, o problema descrito é de difícil ocorrência, uma vez que a relação com o político ou partido se dá em caráter geral, universal e impessoal, concretizando-se por intermédio de canais formais, tais como instituições representativas e partidos políticos ${ }^{130}$.

128 Nesse sentido, Ramon Maiz (Jama, caleta y camello: la corrupcion como mecanismo de autorrefuerzo del clientelismo político. In: Revista Mexicana de Sociologia, v. 65, nº 1, jan-mar de 2003, Universidad Nacional Autônoma de México, pp. 9-10) afirma: "Pelo contrário, no clientelismo as coisas resultam de modo bem diferente: o intercâmbio próprio do mecanismo clientelar é direto; os eleitores trocam votos com os políticos por recursos materiais em lugar do custoso processo de agregação de interesses e de inclinação de ideologia programática. Assim, o esforço organizativo se concentra no estabelecimento de canais, laços e vínculos de troca, e na distribuição particularista de recursos que, em lugar de seguirem os critérios universalistas orientadores de políticas públicas, procedem mediante uma troca material concreta e não mediada" (tradução livre do autor). No original: "Por el contrario, en el clientelismo las cosas resultan de modo bien diferente: el intercambio propio del mecanismo clientelar es directo; los electores intercambian con los políticos votos por recursos materiales en lugar del costoso proceso de agregación de intereses y de decantación de ideología programática. Así, el esfuerzo organizativo se centra en el establecimiento de canales, lazos y vínculos de intercambio, y en la distribución particularista de recursos que, en lugar de seguir los criterios universalistas orientadores de políticas públicas, proceden mediante un intercambio material concreto y no mediado".

129 Ramon Maiz. Jama, caleta y camello: la corrupcion como mecanismo de autorrefuerzo del clientelismo político. In: Revista Mexicana de Sociologia, v. 65, $\mathrm{n}^{\circ}$ 1, jan-marde 2003, Universidad Nacional Autônoma de México, p. 16. No original: “(...) De este modo, en primer lugar, la confianza particularizad en cuanto dependiente de actores concretos y experiencias específicas, hace muy problemática su generalización a otros actores sociales ajenos al circuito de su producción. De esta suerte, la inhibición social de confianza universalista, por encima incluso de intereses comunes, se superpone a la ausencia de interacción social y comunicativa, propia de la red vertical clientelar. En segundo lugar, y a consecuencia de lo anterior, la disgregación focalizada a través de la red vertical del clientelismo se compatibiliza con y/o reproduce la desconfianza generalizada en los iguales, pese a poseer los mismo intereses objetivos.

Por tanto, el clientelismo no sólo emerge en ellos, sino que refuerza contextos sociales de desconfianza (universal) generalizada; constituye el mecanismo portador de una peculiar economía política de la desconfianza: se nutre de ella y la reproduce de modo ampliado. El capital social de base local y particularista impide la generalización de capital social basado en lazos grupales de interés compartido. La ausencia de confianza genera una importante falta de incentivo para la acción colectiva, pues al aislar a unos de otros, volviéndolos competitivos entre ellos, se bloquea la cooperación entre los clientes...".

130 Ramon Maiz. Jama, caleta y camello: la corrupcion como mecanismo de autorrefuerzo del clientelismo político. In: Revista Mexicana de Sociologia, v. 65, $\mathrm{n}^{\circ}$ 1, jan-mar de 2003, Universidad Nacional Autônoma de México, p. 16. No original: "Sin embargo, del mismo modo en que el intercambio clientelar es, como se ha visto, un intercambio directo, la confianza propia del clientelismo - a diferencia de la confianza generalizada, universal e impersonal en los otros y en las instituciones propias del capital 
As diferenças acima descritas repercutem também na eficiência das funções fiscais exercidas pelo Estado. Partindo-se do pressuposto de que nele predomina o vínculo político programático, em que a entrega de vantagens à sociedade ocorre para toda sociedade, indiscriminadamente, isto é, sem qualquer vínculo partidário, é fácil concluir que o desempenho das funções alocativa, distributiva e até estabilizadora será satisfatório, uma vez que os recursos serão aplicados e direcionados em prol de toda a coletividade e não apenas de um determinado grupo ligado ao poder ${ }^{131}$.

No Estado em que se sobressai o vínculo clientelar, o mesmo não se pode afirmar em relação à eficácia das funções fiscais, uma vez que o esforço estatal empregado, em franco prejuízo à sociedade, será dirigido para o atendimento de fins particulares, mais precisamente daqueles que apoiaram o partido ou votaram no governante ${ }^{132}$.

Sobre essas bases, a alocação de recursos já se inicia de forma equivocada, tendo em vista que os critérios para sua ocorrência não estão relacionados ao melhor atendimento das necessidades da população, mas partem da ideia da recompensa dirigida aos votantes e do atendimento de favores pessoais a esses eleitores. Em consequência disso, também resta prejudicado o correto exercício da função distributiva, até mesmo porque o predomínio da prática clientelista acaba por aumentar as desigualdades ao não permitir a adequada

social y de la política basada en vínculos programáticos en partidos políticos e instituciones representativas formales - se caracteriza por la particularización".

131 Uma justificativa para essa conclusão pode ser retirada dos fundamentos expostos por Ramon Maiz (Jama, caleta y camello: la corrupcion como mecanismo de autorrefuerzo del clientelismo político. In: Revista Mexicana de Sociologia, v. 65, $\mathrm{n}^{\circ}$ 1, jan-mar de 2003, Universidad Nacional Autônoma de México, p. 11), quando alega que “(...) o vínculo programático contém o importante 'desencorajamento' no curto prazo, o qual se origina dos critérios universalistas que regulam o controle das promessas eleitorais gerais (programmatic accountability), próprio das políticas públicas regulares, que pressiona para a distribuição de bens coletivos, isto é, para todos e não apenas para recompensar os votantes e excluir os que apoiaram outros partidos” (tradução livre do autor). No original: “(...) el vínculo programático contiene el importante 'desincentivo' en el corto plazo, que se deriva de los criterios universalistas que regulan el control de las promesas electorales generales (programmatic accountability), propio de las políticas públicas regulares, que presiona para la distribución de bienes colectivos, esto es, para todos y no sólo para recompensar a los votantes y excluir a los que han apoyado a otros partidos".

132 Nesse sentido, Ramon Maiz (Jama, caleta y camello: la corrupcion como mecanismo de autorrefuerzo del clientelismo político. In: Revista Mexicana de Sociologia, v. 65, $\mathrm{n}^{\circ}$ 1, jan-mar de 2003, Universidad Nacional Autônoma de México, p. 11) esclarece que "o dispositivo clientelar, ao invés, distribui benefícios materiais em atenção estrita aos partidários, aos que apóiam ou votam para o partido que oferece os benefícios, gerando um peculiar controle particularista do cumprimento das promessas eleitorais (particularistic accountability), mediante o qual os votantes reclamam ao político serviços e favores concretos e personalizados, à margem dos critérios generalistas das políticas públicas" (tradução livre do autor). No original: "El dispositivo clientelar, en cambio, distribuye beneficios materiales en atención estricta a los partisanos, a los que apoyan o votan por el partido que ofrece los beneficios, generando un peculiar control particularista del cumplimiento de las promesas electorales (particularistic accountability), mediante el cual los votantes reclaman al político servicios y favores concretos y personalizados, al margen de los criterios generalistas de las políticas públicas". 
repartição de renda e riqueza àqueles que não deram apoio ao governante (ou ao seu partido) ou ao direcionar despesas governamentais em benefício de seus partidários, em detrimento daqueles realmente necessitados.

Se é verdade que o clientelismo frustra o correto atendimento das funções fiscais, principalmente as distributiva e alocativa, não menos verdade é que traz em seu âmago uma lógica própria "distributiva". O clientelismo representa, na verdade, uma instituição informal, estruturada mediante redes sociais, as quais se vinculam a outras redes mais amplas. Por esse motivo é que se pode afirmar que o clientelismo, por intermédio dessas redes, é fonte de recursos políticos, os quais proporcionam a distribuição de bens e serviços aos participantes dessas mesmas redes ${ }^{133}$.

Em que pese tudo aqui afirmado, nem sempre a troca de benesses, característica do clientelismo, poderá levar à ocorrência da corrupção, principalmente quando não restar evidenciada a utilização ilegal das instituições públicas para fins privados.

\subsubsection{Coronelismo}

O coronelismo foi um sistema político que surgiu no Brasil, na época da Primeira República. Representava o domínio político privado exercido pelos possuidores de terras, chefes políticos da época ${ }^{134}$.

133 Desse entendimento não discrepa Ramon Maiz (Jama, caleta y camello: la corrupcion como mecanismo de autorrefuerzo del clientelismo político. In: Revista Mexicana de Sociologia, v. 65, $\mathrm{n}^{\circ}$ 1, jan-mar de 2003, Universidad Nacional Autônoma de México, pp. 12-13), que afirma: “(...) As redes clientelares constituem, por esse motivo, recursos políticos em sentido estrito, de tal modo que aos recursos de primeira ordem de intercâmbio (favores, votos etc.) haverá de acrescentar outros 'recursos de segunda ordem' (conexões e relações pessoais, amizade por interesse etc.), que se convertem em canal obrigatório para a obtenção individualizada de benefícios mútuos. As redes se configuram como círculos concêntricos ao redor do mediador ou broker [agente, intermediário], cada um deles com diferente grau de contato com aquele e distinto acesso aos bens e serviços que se distribuem (Auyero, 1999)" (tradução livre do autor). No original: “(...) Las redes clientelares constituyen, por este motivo, recursos políticos en sentido estricto, de tal modo que a los recursos de primer orden del intercambio (favores, votos, etc.), han de añadirse otros 'recursos de segundo orden' (conexiones y relaciones personales, amistad instrumental, etc.), que se convierten en canal obligado para la obtención individualizada de beneficios mutuos. Las redes se configuran como círculos concêntricos alrededor del mediador o broker, cada uno de ellos con diferente grado de contacto con aquél y distinto acceso a los bienes y servicios que se distribuyen (Auyero, 1999)". Para uma análise do clientelismo e sua influência sobre o desenvolvimento, ver Rene Lemarchand e Keith Legg (Political clientelism and development: a preliminary analysis. In: Comparative Politics, v. 4, $\mathrm{n}^{\circ}$ 2, jan. 1972, Ph. D. Program in Political Science of the City University of New York, pp. 149-178).

134 Victor Nunes Leal. Coronelismo, enxada e voto: o município e o regime representativo no Brasil. $3^{\text {a }}$ ed. Rio de Janeiro: Nova Fronteira, 1997, pp. 275-276. 
A abrangência desse domínio se estendia aos municípios predominantemente rurais e era fruto de um ajuste entre o poder privado, em declínio, e o poder público, revigorado. $\mathrm{O}$ acordo estabelecido tornou-se necessário com a abolição da escravatura, o advento da República e a ampliação do voto, situações essas que tornaram os votos dos trabalhadores das áreas rurais cada vez mais importantes. Os possuidores de terras (coronéis ${ }^{135}$ ) passaram, então, a ter influência política sobre esses trabalhadores, os quais não possuíam instrução suficiente para o exercício do voto consciente. O poder público, por sua vez, passou a ter nos donos das terras um forte aliado para arrebanhar esses votos ${ }^{136}$.

As bases do acordo proporcionavam vantagens para ambos os lados. Os possuidores de terras, nas eleições estaduais e federais, angariavam votos para os candidatos da ala governista; em troca, obtinham apoio para a manutenção do seu poder, que era exercido no âmbito municipal ${ }^{137}$.

No sistema político coronelista havia forte dependência do município em relação ao governante estadual, inclusive no que diz respeito à obtenção de receitas ${ }^{138}$. Tal submissão

135 A origem dos vocábulos "coronel" e "coronelismo" é minuciosamente descrita por Basílio de Magalhães (In: LEAL, Victor Nunes. Coronelismo, enxada e voto: o município e o regime representativo no Brasil. $3^{\text {a }}$ ed. Rio de Janeiro: Nova Fronteira, 1997, nota ao capítulo primeiro, pp. 290-291): "Durante quase um século, em cada um dos nossos municípios existia um regimento da Guarda Nacional. O posto de 'coronel' era geralmente concedido ao chefe político da comuna. Ele e os outros oficiais uma vez inteirados das respectivas nomeações, tratavam logo de obter as patentes, pagando-lhes os emolumentos e averbações, para que pudessem elas produzir os seus efeitos legais. (...)

Eram, de ordinário, os mais opulentos fazendeiros ou os comerciantes e industriais mais abastados, os que exerciam, em cada município, o comando em-chefe da Guarda Nacional, ao mesmo tempo que a direção política, quase ditatorial, senão patriarcal, que lhes confiava o governo provincial. Tal estado de coisas passou da Monarquia para a República, até ser declarada extinta a criação de Feijó. Mas o sistema ficou arraigado de tal modo na mentalidade sertaneja, que até hoje recebem popularmente o tratamento de 'coronéis' os que têm em mãos o bastão de comando da política edilícia ou os chefes de partidos de maior influência na comuna, isto é, os mandões dos corrilhos de campanário.(...)

Homens ricos, ostentando vaidosamente os seus bens de fortuna, gastando os rendimentos em diversões lícitas e ilícitas - foram tais 'coronéis' os que deram ensejo ao significado especial que tão elevado posto militar assumiu designando demopsicologicamente 'o indivíduo que paga as despesas'. E, assim, penetrou o vocábulo 'coronelismo' na evolução político-social do nosso país, particularmente na atividade partidária dos municípios brasileiros".

136 Victor Nunes Leal. Coronelismo, enxada e voto: o município e o regime representativo no Brasil. $3^{\mathrm{a}}$ ed. Rio de Janeiro: Nova Fronteira, 1997, pp. 275-276, 278-279.

137 Victor Nunes Leal. Coronelismo, enxada e voto: o município e o regime representativo no Brasil. $3^{\mathrm{a}}$ ed. Rio de Janeiro: Nova Fronteira, 1997, p. 279. As especificidades desse acordo são bem descritas por Raymundo Faoro (Os donos do poder: formação do patronato político brasileiro. $3^{\mathrm{a}}$ ed. rev. São Paulo: Globo, 2001, p. 711): 'O coronelismo se manifesta num 'compromisso', uma 'troca de proveitos' entre o chefe político e o governo estadual, com o atendimento, por parte daquele, dos interesses e reivindicações do eleitorado rural".

138 Victor Nunes Leal. Coronelismo, enxada e voto: o município e o regime representativo no Brasil. $3^{\text {a }}$ ed. Rio de Janeiro: Nova Fronteira, 1997, p. 280. Raymundo Faoro (Os donos do poder: formação do patronato político brasileiro. $3^{a}$ ed. rev. São Paulo: Globo, 2001, p. 708) também ressalta essa característica do coronelismo ao afirmar: "Nesse esquema da supremacia estadual e da eleição sancionadora se insere o coronelismo. Ele se irmana à oligarquia das unidades federadas, num recíproco 
municipal garantia a permanência do partido da situação no poder e era "compensada com uma extensa autonomia extralegal, concedida pelo governo do Estado ao partido local de sua preferência" ${ }^{\prime 39}$.

O coronelismo também proporcionava uma confusão entre o público e o privado, mesmo porque havia a utilização do aparato estatal para o atendimento de benefícios privados. Exemplo disso, aliás, era a indicação, pelo coronel, de ocupantes de empregos públicos estaduais e municipais ${ }^{140}$.

A partir de 1930, com o desenvolvimento da indústria, o aprimoramento do processo eleitoral e o aumento da população urbana, o coronelismo passou a sofrer declínio ${ }^{141}$, persistindo em nossos dias sob formas adaptadas, em locais isolados do país ${ }^{142}$.

Se é verdade que atualmente o coronelismo não se apresenta com frequência e não se mostra da forma como originalmente se concebeu, não menos verdade é que seu estudo é importante não apenas para a compreensão da situação atual da autonomia dos municípios, mas também para o entendimento de como ocorre o desvio de recursos públicos para o atingimento de fins privados e eleitorais.

jogo de interações ativas. O comando do sistema caberá ao governador, isto é, ao grupo estadual por ele representado, intermediário dos favores e benefícios da União sobre as comunas. Entre o governador e o coronel a relação é de obediência, autoritariamente garantida pela milícia estadual e pelos instrumentos financeiros e econômicos que partem daquele".

139 Victor Nunes Leal. Coronelismo, enxada e voto: o município e o regime representativo no Brasil. $3^{\mathrm{a}}$ ed. Rio de Janeiro: Nova Fronteira, 1997, p. 281.

140 Raymundo Faoro. Os donos do poder: formação do patronato político brasileiro. $3^{\text {a }}$ ed. rev. São Paulo: Globo, 2001, p. 711.

141 Victor Nunes Leal. Coronelismo, enxada e voto: o município e o regime representativo no Brasil. $3^{\mathrm{a}} \mathrm{ed}$. Rio de Janeiro: Nova Fronteira, 1997, p. 283.

142 Há, porém, quem discorde desse posicionamento. Segundo José Murilo de Carvalho (Mandonismo, Coronelismo, Clientelismo: Uma Discussão Conceitual. In: Dados - Revista de Ciências Sociais. Rio de Janeiro, $\quad$ v. $40, \quad$ n. $\quad 2, \quad 1997 . \quad$ Disponível http://www.scielo.br/scielo.php?script=sci_arttext\&pid=S0011-52581997000200003\&lng=pt\&nrm=iso, acessado em 04.08.2009), não seria possível afirmar a existência atual do coronelismo, mas uma ampliação da prática clientelista. Esclarece o autor: "Os autores que vêem coronelismo no meio urbano e em fases recentes da história do país estão falando simplesmente de clientelismo. As relações clientelísticas, nesse caso, dispensam a presença do coronel, pois ela se dá entre o governo, ou políticos, e setores pobres da população. Deputados trocam votos por empregos e serviços públicos que conseguem graças à sua capacidade de influir sobre o Poder Executivo. Nesse sentido, é possível mesmo dizer que o clientelismo se ampliou com o fim do coronelismo e que ele aumenta com o decréscimo do mandonismo. À medida que os chefes políticos locais perdem a capacidade de controlar os votos da população, eles deixam de ser parceiros interessantes para o governo, que passa a tratar com os eleitores, transferindo para estes a relação clientelística". 


\subsection{Corrupção}

\subsubsection{Conceito de corrupção}

O termo corrupção vem da palavra latina corruptione, que significa alteração, deterioração, depravação. Também relacionado a esse termo é o verbo latino corrumpo, que quer dizer destruir, fazer em pedaços. Da simples análise etimológica da expressão, percebe-se não só o efeito nefasto que seu sentido apresenta como também a amplitude de significados que pode representar.

Outro fato importante a ser observado é que não existe um sentido único para definir as ações que podem ser consideradas corruptas, uma vez que o significado delas pode sofrer alterações em razão de diversos fatores, tais como o da cultura de determinado povo, do momento histórico e do ordenamento jurídico vigente no país ${ }^{143}$. De igual modo, as configurações e efeitos da corrupção, bem como a forma como se propaga na sociedade diferem de país a país ${ }^{144}$.

Como forma de estabelecer parâmetros para se compreender o alcance do conceito, existem autores que procuram identificar as formas de corrupção. Nesse sentido, Fernando Filgueiras aponta que a corrupção sob a forma política ou republicana representaria a prática de atos discordantes com os princípios de "bem viver" e de "bom governo" "145 Já a corrupção representada pela forma cultural ou comunitarista significaria aquela consubstanciada por atos contrários à cultura - esta ditada pela tradição - de uma determinada comunidade ${ }^{146}$. Sob a forma social ou autorizativa, estaria a corrupção "atrelada à usurpação, a qual significa a tomada violenta dos bens e da vida de uma pessoa por parte de outra, visando a satisfazer, exclusivamente, seu bem viver"147. A corrupção sob a forma econômica ou liberal, por sua vez, estaria relacionada a "qualquer tipo de

143 É por esse motivo que Marcos Otávio Bezerra (Corrupção: um estudo sobre poder público e relações pessoais no Brasil. Rio de Janeiro: Relume-Dumará, ANPOCS, 1995, pp. 12-13) esclarece que "as denúncias a respeito de quais práticas são corruptas e a avaliação sobre o grau de corrupção que elas contêm estão condicionadas aos contextos a partir dos quais elas são realizadas e aos critérios adotados para elaborá-las, não havendo, assim, um consenso entre as diversas sociedades e entre os diversos grupos no interior de cada uma delas quanto a que ações especificamente são corruptas e corruptoras". ELLIOT, Kimberly Ann. Introdução. In: ELLIOT, Kimberly Ann.. A corrupção e a economia global. Tradução de Marsel Nascimento Gonçalves de Souza. Brasília: Editora Universidade de Brasília, 2002, p. 17. Título original: Corruption and the global economy.

145 Corrupção, democracia e legitimidade. Belo Horizonte: Editora UFMG, 2008, p. 122.

146 Corrupção, democracia e legitimidade. Belo Horizonte: Editora UFMG, 2008, pp. 116-117.

147 Corrupção, democracia e legitimidade. Belo Horizonte: Editora UFMG, 2008, p. 127. 
apropriação indébita de um domínio público, tendo em vista sua ilegalidade", apropriação essa caracterizada pela fraude ${ }^{148}$.

O fato é que, na verdade, muitos podem ser os significados da corrupção. Eles serão os mais variados na medida em que o estudo sobre a questão avançar em áreas distintas de análise (moral, ética, jurídica, econômica, sociológica etc.).

Diante da diversidade de elementos, torna-se realmente difícil estabelecer um sentido exclusivo para o termo. Apesar da inexistência de um direcionamento único para a definição de corrupção, o certo é que se torna possível conceber seu esboço geral a partir da percepção de elementos comuns à maioria dos significados, dentro de determinados critérios. Dessa forma, antes de se estabelecer um conceito próprio, importante mencionar alguns exemplos extraídos da doutrina:

A corrupção pública é uma relação social (de caráter pessoal, extramercado e ilegal) que se estabelece entre dois agentes ou dois grupos de agentes (corruptos e corruptores), cujo objetivo é a transferência de renda dentro da sociedade ou do fundo público para a realização de fins estritamente privados. Tal relação envolve a troca de favores entre os grupos de agentes e geralmente a remuneração dos corruptos com o uso da propina e de qualquer tipo de pay-off (prêmio, recompensa). (Marcos Fernandes Gonçalves da Silva) ${ }^{149}$

(...) a corrupção pública (em suas variantes penal e administrativa) se manifesta quando a gestão do interesse público está viciada ou pervertida ao se produzir à margem ou de forma contrária ao que determinadas leis, princípios e valores éticos e morais comumente aceitos estabelecem e exigem. (José Manuel Urquiza) ${ }^{150}$

A corrupção ocorre na interface dos setores público e privado. Sempre que uma autoridade pública possui poder discricionário sobre a distribuição de um benefício ou de um custo para o setor privado, criam-se incentivos para que haja suborno. (Susan Rose-Ackerman) ${ }^{151}$

Atos de corrupção pública são condutas ilegais e imorais de agentes públicos consistentes em substituir as finalidades da função pública pelo interesse particular na obtenção de vantagens, ou seja, desviar poderes dolosamente. (Waldo Fazzio Júnior) ${ }^{152}$

Assim se designa o fenômeno pelo qual um funcionário público é levado a agir de modo diverso dos padrões normativos do sistema, favorecendo interesses particulares em troco de recompensa. (Gianfranco Pasquino) ${ }^{153}$

148 Corrupção, democracia e legitimidade. Belo Horizonte: Editora UFMG, 2008, p. 136.

149 A economia política da corrupção no Brasil. São Paulo: SENAC São Paulo, 2001, pp. 51 e 54.

150 Corrupción municipal: por qué se produce y cómo evitarla. Córdoba: Almuzara, 2005, pp. 14-15 (tradução livre do autor). No original: “(...) la corrupción pública (em sus variantes penal y administrativa) se manifiesta cuando la gestión del interés público está viciada o pervertida, al producirse al margen o de forma contraria a lo que determinadas leyes, principios y valores éticos y morales comúnmente aceptados establecen y exigen".

151 A economia política da corrupção. In: ELLIOT, Kimberly Ann (org.). A corrupção e a economia global. Tradução de Marsel Nascimento Gonçalves de Souza. Brasília: Editora Universidade de Brasília, 2002, p. 59. Título original: Corruption and the global economy.

152 Corrupção no poder público: peculato, concussão, corrupção passiva e prevaricação. São Paulo: Atlas, 2002, p. 39. 
Depreende-se que os conceitos acima descritos partem da análise da corrupção pública, sem se imiscuir nas hipóteses de corrupção privada, assim entendida como aquela "que se desenvolve fora dos órgãos e entidades que compõem a Administração Pública, sem pertinência com esta" ${ }^{\text {154 }}$. O objetivo do presente trabalho, da mesma forma, é apenas a análise da corrupção pública, uma vez que diretamente relacionada a desvio de recursos públicos.

Não obstante as definições acima servirem como parâmetro para a delimitação do objeto de estudo, resta ainda um obstáculo a ser superado e que diz respeito, justamente, à definição jurídica de corrupção em nosso país.

O Código Penal brasileiro, em seu artigo 317, prevê o crime de corrupção passiva, assim o conceituando: "solicitar ou receber, para si ou para outrem, direta ou indiretamente, ainda que fora da função ou antes de assumi-la, mas em razão dela, vantagem indevida, ou aceitar promessa de tal vantagem”. O delito de corrupção ativa também consta do mesmo diploma penal, no artigo 333, o qual estabelece que pratica o crime aquele que "oferecer ou prometer vantagem indevida a funcionário público, para determiná-lo a praticar, omitir ou retardar ato de ofício”.

A ideia de corrupção, descrita nos dois artigos anteriores, é demasiadamente restrita, pois não comporta outras situações em que há a utilização do bem público para fins privados. Esses conceitos, então, não podem servir de baliza única para o completo enquadramento do significado de corrupção, sob pena de se afastar outras condutas que bem poderiam representar o desvio de recursos públicos e outras práticas deletérias ao bem comum $^{155}$.

153 Gianfranco Pasquino (Corrupção. In: BOBBIO, Norberto; MATTEUCCI, Nicola; PASQUINO, Gianfranco. Dicionário de política. $12^{\mathrm{a}}$ ed. Tradução de Carmen C. Varriale et al. Coord. da tradução: João Ferreira. Brasília: Editora Universidade de Brasília, 2002, v. 1, p. 291).

154 Waldo Fazzio Júnior. Corrupção no poder público: peculato, concussão, corrupção passiva e prevaricação. São Paulo: Atlas, 2002, p. 30. John Kleinig e William C. Heffernan (The corruptibility of corruption. In: HEFFERNAN, William C.; KLEINIG, John (org.). Private and Public Corruption. Oxford: Rowman \& Littlefield Publishers, Inc., 2004, p. 3) também sustentam que a corrupção pode se dar no âmbito privado. No original: "Corruption is not the exclusive failing of public officers; there may also be personal corruption, corrupt institutions, and corrupt cultures".

155 Nesse sentido é o entendimento de Waldo Fazzio Júnior (Corrupção no poder público: peculato, concussão, corrupção passiva e prevaricação. São Paulo: Atlas, 2002, p. 36): "Hoje, corrupção pública é expressão intimamente amarrada ao tráfico de deveres públicos e ostenta abrangência bastante elástica. Sua utilização, pelo Código Penal, denota evidente redução de sua amplitude significativa, traduzindo-a mediante as condutas descritas nos arts. 317 e 333, respectivamente, corrupção passiva e corrupção ativa. O estatuto sancionador cuida da corrupção pública em sentido estrito. (...) 
Exemplo de que o conceito de corrupção não pode se limitar a termos tão restritos pode ser encontrado nos dispositivos da Convenção Interamericana contra a Corrupção, documento firmado na cidade de Caracas, em março de 1996, no âmbito dos Estados membros da Organização dos Estados Americanos. No artigo sexto do mencionado documento há a descrição ampla de atos considerados como de corrupção:

Artigo VI

Atos de Corrupção

1. Esta Convenção é aplicável aos seguintes atos de corrupção:

a. a solicitação ou a aceitação, direta ou indiretamente, por um funcionário público ou pessoa que exerça funções públicas, de qualquer objeto de valor pecuniário ou de outros benefícios como dádivas, favores, promessas ou vantagens para si mesmo ou para outra pessoa ou entidade em troca da realização ou omissão de qualquer ato no exercício de suas funções públicas;

b. a oferta ou outorga, direta ou indiretamente, a um funcionário público ou pessoa que exerça funções públicas, de qualquer objeto de valor pecuniário ou de outros benefícios como dádivas, favores, promessas ou vantagens a esse funcionário público ou outra pessoa ou entidade em troca da realização ou omissão de qualquer ato no exercício de suas funções públicas;

c. a realização, por parte de um funcionário público ou uma pessoa que exerça funções públicas, de qualquer ato ou omissão no exercício de suas funções, a fim de obter ilicitamente benefícios para si mesmo ou para um terceiro;

d. o aproveitamento doloso ou a ocultação de bens provenientes de qualquer dos atos a que se refere este artigo; e

e. a participação, como autor, co-autor, instigador, cúmplice, acobertador ou mediante qualquer outro modo na perpetração, na tentativa de perpetração ou na associação ou confabulação para perpetrar qualquer dos atos a que se refere este artigo.

2. Esta Convenção também é aplicável por acordo mútuo entre dois ou mais Estados Partes com referência a quaisquer outros atos de corrupção que a própria Convenção não defina. ${ }^{156}$

Considerar corrupção apenas o que o Código Penal define como tal significa perder de vista a própria razão de ser dos crimes contra a Administração Pública praticados por agentes públicos e o fundamento de sua punibilidade. A noção de corrupção pública não se limita à timidez da nomenclatura jurídica positiva".

156 Tradução contida no anexo do Decreto $\mathrm{n}^{\circ} 4.410$, de 7 de outubro de 2002. No original: "Artículo VI Actos de Corrupción - 1. La presente Convención es aplicable a los siguientes actos de corrupción: a. El requerimiento o la aceptación, directa o indirectamente, por un funcionario público o una persona que ejerza funciones públicas, de cualquier objeto de valor pecuniario u otros beneficios como dádivas, favores, promesas o ventajas para sí mismo o para otra persona o entidad a cambio de la realización u omisión de cualquier acto en el ejercicio de sus funciones públicas; b. El ofrecimiento o el otorgamiento, directa o indirectamente, a un funcionario público o a una persona que ejerza funciones públicas, de cualquier objeto de valor pecuniario u otros beneficios como dádivas, favores, promesas o ventajas para ese funcionario público o para otra persona o entidad a cambio de la realización u omisión de cualquier acto en el ejercicio de sus funciones públicas; c. La realización por parte de un funcionario público o una persona que ejerza funciones públicas de cualquier acto u omisión en el ejercicio de sus funciones, con el fin de obtener ilícitamente beneficios para sí mismo o para un tercero; d. El aprovechamiento doloso u ocultación de bienes provenientes de cualesquiera de los actos a los que se refiere el presente artículo; y e. La participación como autor, coautor, instigador, cómplice, encubridor o en cualquier otra forma en la 
No Brasil, a Convenção Interamericana contra a Corrupção foi aprovada pelo Congresso Nacional por intermédio do Decreto Legislativo $n^{\circ}$ 152, de 25 de junho de 2002 e promulgada por meio do Decreto $\mathrm{n}^{\circ} 4.410$, de 7 de outubro de $2002^{157}$. Depreende-se de seu texto a amplitude conferida à corrupção no exercício das funções públicas, pois estabelece parâmetros mais abrangentes que os do Código Penal brasileiro para a identificação dos respectivos atos de desvirtuamento. Na mesma Convenção, a definição de função pública é extensiva ${ }^{158}$, assim como a de funcionário público, funcionário de governo e servidor público ${ }^{159}$, os quais, adotando-se terminologia da doutrina brasileira, podem ser resumidos genericamente como agentes públicos ${ }^{160}$ (ou agentes estatais ${ }^{161}$ ).

comisión, tentativa de comisión, asociación o confabulación para la comisión de cualquiera de los actos a los que se refiere el presente artículo. 2. La presente Convención también será aplicable, de mutuo acuerdo entre dos o más Estados Partes, en relación con cualquier otro acto de corrupción no contemplado en ella".

157 Para um estudo aprofundado a respeito da Convenção Interamericana contra a Corrupção, ver Carlos A. Manfroni (La Convención Interamericana contra la Corrupción: anotada y comentada. $2^{\mathrm{a}}$ ed. atual. Buenos Aires: Abeledo-Perrot, 2001).

158 Regis Fernandes de Oliveira (Curso de direito financeiro. São Paulo: Editora Revista dos Tribunais, 2006, p. 229) lembra que, "no direito brasileiro, a noção de função pública significa a possibilidade jurídica de poder agir, mediante dever jurídico da ação, em atendimento e em cumprimento a determinada finalidade insculpida em norma jurídica, que giza sua atribuição. Isto é, pressupõe um direcionamento a determinada finalidade e impõe a norma o dever de agir". Celso Antônio Bandeira de Mello (Curso de direito administrativo. $17^{\mathrm{a}}$ ed. rev. e atual. São Paulo: Malheiros, 2004, p. 234) complementa, esclarecendo que as "funções públicas são plexos unitários de atribuições, criados por lei, correspondentes a encargos de direção, chefia ou assessoramento, a serem exercidas por titular de cargo efetivo, da confiança da autoridade que as preenche (art. 37, V, da Constituição)".

159 De acordo com a Convenção, “entende-se por: 'Função pública' toda atividade, temporária ou permanente, remunerada ou honorária realizada por uma pessoa física em nome do Estado ou a serviço do Estado ou de suas entidades, em qualquer de seus níveis hierárquicos.

'Funcionário público', 'funcionário de governo' ou 'servidor público' qualquer funcionário ou empregado de um Estado ou de suas entidades, inclusive os que tenham sido selecionados, nomeados ou eleitos para desempenhar atividades ou funções em nome do Estado ou a serviço do Estado em qualquer de seus níveis hierárquicos. (...)". Tradução contida no anexo do Decreto $n^{\circ} 4.410$, de 7 de outubro de 2002.

No original: "Para los fines de la presente Convención, se entiende por: 'Función pública', toda actividad temporal o permanente, remunerada u honoraria, realizada por una persona natural en nombre del Estado o al servicio del Estado o de sus entidades, en cualquiera de sus niveles jerárquicos.

'Funcionario público', 'oficial gubernamental' o 'servidor público', cualquier funcionario o empleado del Estado o de sus entidades, incluidos los que han sido seleccionados, designados o electos para desempeñar actividades o funciones en nombre del Estado o al servicio del Estado, en todos sus niveles jerárquicos. (...)"

160 O termo "agente público" é utilizado por parte da doutrina para designar, de forma genérica, aquele que exerce função estatal, manifestando a vontade do Poder Público. De acordo com Edmir Netto de Araújo (Curso de direito administrativo. $3^{\mathrm{a}}$ ed. rev., ampl. e atual. São Paulo: Saraiva, 2007, p. 253), “a expressão agente público é, portanto, de grande amplitude e aplicável a um sem-número de hipóteses de caracterização do Estado como Administração". Segundo ele, "todo aquele que, de alguma forma, sob qualquer categoria ou título jurídico, desempenha função ou atribuição considerada pelo Poder Público como a si pertinente, seja em virtude de relação de trabalho (estatutária ou não), seja em razão de relação contratual, encargo público ou qualquer outra forma de função de natureza pública, será, enquanto a desempenhar, um agente público". Bem por isso, o autor considera como três grupos de agentes públicos "os agentes políticos, os servidores públicos e os particulares em colaboração com a Administração". 
Percebe-se da leitura do artigo sexto da Convenção que os atos de corrupção não podem se limitar aos tipos penais de "corrupção ativa" e de "corrupção passiva" descritos no Código Penal brasileiro. Ao contrário, existem outros tipos que retratam o desvirtuamento da função pública para o alcance de fins privados. Dentre eles, podem ser destacados os delitos de peculato ${ }^{162}$, concussão ${ }^{163}$, prevaricação ${ }^{164}$, emprego irregular de verbas ou rendas públicas ${ }^{165}$ e a maioria dos tipos penais previstos no capítulo I (Dos crimes praticados por funcionário público contra a Administração em geral), do título XI (Dos crimes contra a Administração Pública), do Código Penal.

Fora do âmbito exclusivamente penal também é possível citar a Lei de Improbidade Administrativa (Lei n 8.429, de 2 de junho de 1992), que disciplina as sanções aplicáveis aos agentes públicos nas hipóteses de enriquecimento ilícito no exercício de mandato, cargo, emprego ou função na administração pública direta, indireta ou fundacional. A lei

Diogo de Figueiredo Moreira Neto (Curso de direito administrativo: parte introdutória, parte geral e parte especial. 14 a ed. rev., ampl. e atual. Rio de Janeiro: Forense, 2005, p. 283) utiliza a expressão ampla "pessoal", uma vez que "mais abrangente que servidores públicos, pois engloba todos os que são estipendiados pelas entidades da Administração direta e indireta, o que inclui os servidores públicos, os militares, e os empregados das autarquias, empresas públicas, sociedades de economia mista, suas respectivas subsidiárias e fundações públicas com personalidade de direito privado". Para ele, a expressão "agente público" apresenta uma conotação mais restrita, pois designa "todos aqueles que, servidores públicos ou não, estão legalmente intitulados a exercer, em nível decisório, uma parcela do poder público, investidos de competência especificamente definida pela ordem jurídica" (Op. cit., p. 284). Por fim, importante mencionar, também, o conceito de agente público contido na Lei de Improbidade Administrativa (Lei n 8.429, de 2 de junho de 1992): “Art. $2^{\circ}$ Reputa-se agente público, para os efeitos desta lei, todo aquele que exerce, ainda que transitoriamente ou sem remuneração, por eleição, nomeação, designação, contratação ou qualquer outra forma de investidura ou vínculo, mandato, cargo, emprego ou função nas entidades mencionadas no artigo anterior". As entidades a que se refere o mencionado dispositivo dizem respeito à "administração direta, indireta ou fundacional de qualquer dos Poderes da União, dos Estados, do Distrito Federal, dos Municípios, de Território, de empresa incorporada ao patrimônio público ou de entidade para cuja criação ou custeio o erário haja concorrido ou concorra com mais de cinqüenta por cento do patrimônio ou da receita anual" (art. $1^{\circ}$, caput, da Lei de Improbidade Administrativa), além de "entidade que receba subvenção, benefício ou incentivo, fiscal ou creditício, de órgão público bem como daquelas para cuja criação ou custeio o erário haja concorrido ou concorra com menos de cinqüenta por cento do patrimônio ou da receita anual" (art. $1^{\circ}$, parágrafo único, da Lei de Improbidade Administrativa).

161 Essa é a designação genérica adotada por Marçal Justen Filho (Curso de direito administrativo. São Paulo: Saraiva, 2005, p. 568), o qual esclarece que comumente o termo é usado como sinônimo de "agente público".

162 Código Penal: “Art. 312 - Apropriar-se o funcionário público de dinheiro, valor ou qualquer outro bem móvel, público ou particular, de que tem a posse em razão do cargo, ou desviá-lo, em proveito próprio ou alheio (...) $\S 1^{\circ}$ Aplica-se a mesma pena, se o funcionário público, embora não tendo a posse do dinheiro, valor ou bem, o subtrai, ou concorre para que seja subtraído, em proveito próprio ou alheio, valendo-se de facilidade que lhe proporciona a qualidade de funcionário".

163 Código Penal: "Art. 316 - Exigir, para si ou para outrem, direta ou indiretamente, ainda que fora da função ou antes de assumi-la, mas em razão dela, vantagem indevida (...)".

164 Código Penal: "Art. 319 - Retardar ou deixar de praticar, indevidamente, ato de ofício, ou praticá-lo contra disposição expressa de lei, para satisfazer interesse ou sentimento pessoal (...)”.

165 Código Penal: "Art. 315 - Dar às verbas ou rendas públicas aplicação diversa da estabelecida em lei (...)". 
retrata práticas corruptas (corrupção administrativa) ${ }^{166}$, inclusive com a menção expressa a condutas que causam prejuízo ao erário. De fato, enquanto o artigo $9^{\circ}$ da citada lei relaciona os atos que implicam enriquecimento ilícito do agente público - proveito esse obtido em decorrência do exercício da própria função pública ${ }^{167}$, o artigo 10 menciona aquelas ações que resultam na "perda patrimonial, desvio, apropriação, malbaratamento ou dilapidação dos bens ou haveres" de entidades públicas ${ }^{168}$. O artigo 11 relaciona, ainda, os

166 Marino Pazzaglini Filho, Márcio Fernando Elias Rosa e Waldo Fazzio Júnior (Aspectos jurídicos da defesa do patrimônio público. $4^{\text {a }}$ ed. São Paulo: Atlas, 1999, pp. 39-40) bem definem a improbidade administrativa ou corrupção administrativa: "Numa primeira aproximação, improbidade administrativa é o designativo técnico para a chamada corrupção administrativa, que, sob diversas formas, promove o desvirtuamento da Administração Pública e afronta os princípios nucleares da ordem jurídica (Estado de Direito, Democrático e Republicano), revelando-se pela obtenção de vantagens patrimoniais indevidas às expensas do erário, pelo exercício nocivo das funções e empregos públicos, pelo 'tráfico de influência' nas esferas da Administração Pública e pelo favorecimento de poucos em detrimento dos interesses da sociedade, mediante a concessão de obséquios e privilégios ilícitos".

167 "Art. $9^{\circ}$ Constitui ato de improbidade administrativa importando enriquecimento ilícito auferir qualquer tipo de vantagem patrimonial indevida em razão do exercício de cargo, mandato, função, emprego ou atividade nas entidades mencionadas no art. $1^{\circ}$ desta lei, e notadamente: I - receber, para si ou para outrem, dinheiro, bem móvel ou imóvel, ou qualquer outra vantagem econômica, direta ou indireta, a título de comissão, percentagem, gratificação ou presente de quem tenha interesse, direto ou indireto, que possa ser atingido ou amparado por ação ou omissão decorrente das atribuições do agente público; II - perceber vantagem econômica, direta ou indireta, para facilitar a aquisição, permuta ou locação de bem móvel ou imóvel, ou a contratação de serviços pelas entidades referidas no art. $1^{\circ}$ por preço superior ao valor de mercado; III - perceber vantagem econômica, direta ou indireta, para facilitar a alienação, permuta ou locação de bem público ou o fornecimento de serviço por ente estatal por preço inferior ao valor de mercado; IV - utilizar, em obra ou serviço particular, veículos, máquinas, equipamentos ou material de qualquer natureza, de propriedade ou à disposição de qualquer das entidades mencionadas no art. $1^{\circ}$ desta lei, bem como o trabalho de servidores públicos, empregados ou terceiros contratados por essas entidades; $\mathrm{V}$ - receber vantagem econômica de qualquer natureza, direta ou indireta, para tolerar a exploração ou a prática de jogos de azar, de lenocínio, de narcotráfico, de contrabando, de usura ou de qualquer outra atividade ilícita, ou aceitar promessa de tal vantagem; VI - receber vantagem econômica de qualquer natureza, direta ou indireta, para fazer declaração falsa sobre medição ou avaliação em obras públicas ou qualquer outro serviço, ou sobre quantidade, peso, medida, qualidade ou característica de mercadorias ou bens fornecidos a qualquer das entidades mencionadas no art. $1^{\circ}$ desta lei; VII - adquirir, para si ou para outrem, no exercício de mandato, cargo, emprego ou função pública, bens de qualquer natureza cujo valor seja desproporcional à evolução do patrimônio ou à renda do agente público; VIII aceitar emprego, comissão ou exercer atividade de consultoria ou assessoramento para pessoa física ou jurídica que tenha interesse suscetível de ser atingido ou amparado por ação ou omissão decorrente das atribuições do agente público, durante a atividade; IX - perceber vantagem econômica para intermediar a liberação ou aplicação de verba pública de qualquer natureza; X - receber vantagem econômica de qualquer natureza, direta ou indiretamente, para omitir ato de ofício, providência ou declaração a que esteja obrigado; XI - incorporar, por qualquer forma, ao seu patrimônio bens, rendas, verbas ou valores integrantes do acervo patrimonial das entidades mencionadas no art. $1^{\circ}$ desta lei; XII - usar, em proveito próprio, bens, rendas, verbas ou valores integrantes do acervo patrimonial das entidades mencionadas no art. $1^{\circ}$ desta lei".

168 "Art. 10. Constitui ato de improbidade administrativa que causa lesão ao erário qualquer ação ou omissão, dolosa ou culposa, que enseje perda patrimonial, desvio, apropriação, malbaratamento ou dilapidação dos bens ou haveres das entidades referidas no art. $1^{\circ}$ desta lei, e notadamente: I - facilitar ou concorrer por qualquer forma para a incorporação ao patrimônio particular, de pessoa física ou jurídica, de bens, rendas, verbas ou valores integrantes do acervo patrimonial das entidades mencionadas no art. $1^{\circ}$ desta lei; II - permitir ou concorrer para que pessoa física ou jurídica privada utilize bens, rendas, verbas ou valores integrantes do acervo patrimonial das entidades mencionadas no art. $1^{\circ}$ desta lei, sem a observância das formalidades legais ou regulamentares aplicáveis à espécie; III - doar à pessoa física ou jurídica bem como ao ente despersonalizado, ainda que de fins educativos ou assistenciais, bens, rendas, 
atos que, embora por si só não representem automaticamente a presença de corrupção pois dependeriam para isso do necessário aferimento de vantagem ilícita para o próprio agente público ou para terceiro -, atentam contra os princípios da Administração Pública $^{169}$.

Nessa esteira, considerando o que foi até aqui exposto e observando a questão inclusive sob a ótica da legislação brasileira, pode-se conceituar corrupção como o ato contrário ao ordenamento jurídico, praticado por agente público, com o fim de patrocinar interesse próprio ou de particulares.

\subsubsection{A corrupção como risco à República}

Um ponto importante a ser discutido diz respeito ao momento em que a corrupção pode representar uma verdadeira ameaça ao princípio republicano.

De acordo com Renato Janine Ribeiro, dos três regimes de governo mencionados por Montesquieu (monarquia, república e despotismo ${ }^{170}$ ), a corrupção somente poderia

verbas ou valores do patrimônio de qualquer das entidades mencionadas no art. $1^{\circ}$ desta lei, sem observância das formalidades legais e regulamentares aplicáveis à espécie; IV - permitir ou facilitar a alienação, permuta ou locação de bem integrante do patrimônio de qualquer das entidades referidas no art. $1^{\circ}$ desta lei, ou ainda a prestação de serviço por parte delas, por preço inferior ao de mercado; V permitir ou facilitar a aquisição, permuta ou locação de bem ou serviço por preço superior ao de mercado; VI - realizar operação financeira sem observância das normas legais e regulamentares ou aceitar garantia insuficiente ou inidônea; VII - conceder benefício administrativo ou fiscal sem a observância das formalidades legais ou regulamentares aplicáveis à espécie; VIII - frustrar a licitude de processo licitatório ou dispensá-lo indevidamente; IX - ordenar ou permitir a realização de despesas não autorizadas em lei ou regulamento; X - agir negligentemente na arrecadação de tributo ou renda, bem como no que diz respeito à conservação do patrimônio público; XI - liberar verba pública sem a estrita observância das normas pertinentes ou influir de qualquer forma para a sua aplicação irregular; XII permitir, facilitar ou concorrer para que terceiro se enriqueça ilicitamente; XIII - permitir que se utilize, em obra ou serviço particular, veículos, máquinas, equipamentos ou material de qualquer natureza, de propriedade ou à disposição de qualquer das entidades mencionadas no art. $1^{\circ}$ desta lei, bem como o trabalho de servidor público, empregados ou terceiros contratados por essas entidades; XIV - celebrar contrato ou outro instrumento que tenha por objeto a prestação de serviços públicos por meio da gestão associada sem observar as formalidades previstas na lei; XV - celebrar contrato de rateio de consórcio público sem suficiente e prévia dotação orçamentária, ou sem observar as formalidades previstas na lei”.

169 "Art. 11. Constitui ato de improbidade administrativa que atenta contra os princípios da administração pública qualquer ação ou omissão que viole os deveres de honestidade, imparcialidade, legalidade, e lealdade às instituições, e notadamente: I - praticar ato visando fim proibido em lei ou regulamento ou diverso daquele previsto, na regra de competência; II - retardar ou deixar de praticar, indevidamente, ato de ofício; III - revelar fato ou circunstância de que tem ciência em razão das atribuições e que deva permanecer em segredo; IV - negar publicidade aos atos oficiais; V - frustrar a licitude de concurso público; VI - deixar de prestar contas quando esteja obrigado a fazê-lo; VII - revelar ou permitir que chegue ao conhecimento de terceiro, antes da respectiva divulgação oficial, teor de medida política ou econômica capaz de afetar o preço de mercadoria, bem ou serviço".

170 A propósito, estas são as definições de cada um dos regimes elaboradas pelo próprio Montesquieu (Charles-Louis de Secondant, Barão de La Brède e de Montesquieu), na obra Do Espírito das Leis (primeira parte, livro segundo, capítulo I): "Existem três espécies de governo: o Republicano, o 
representar uma ameaça à república. Sendo o cerne do despotismo o próprio aviltamento do ser humano, não teria sentido afirmar que a corrupção lhe geraria algum risco. Quanto à monarquia, a corrupção já seria inerente ao seu sistema, o qual defende a desigualdade entre os homens, partindo do pressuposto de que somente alguns possuem a honra (o nobre, por exemplo), tendo como resultado a existência de privilégios e a apropriação do bem público para finalidades particulares do soberano. Já a República encontraria na corrupção a sua antítese. De fato, no regime republicano prevalece o respeito à coisa pública ${ }^{171}$, em que "o bem pessoal é requisito para produzir o bem social”, representando a corrupção uma ameaça a esse princípio. Em outras palavras, "a república é o regime da ética na política" ${ }^{\prime 72}$.

Na república antiga, em Roma, a corrupção também estava presente, mas era encarada em relação aos costumes. Prezava-se a supremacia do bem comum em detrimento do interesse pessoal, motivo pelo qual se exigia que os cidadãos fossem decentes, ou seja, abrissem mão da liberdade íntima (propugnava-se, inclusive, a contenção sexual). Vale dizer, buscava-se a realização da coletividade e não a realização pessoal, devendo o indivíduo se sacrificar pela coletividade. A virtude era o princípio da república; a corrupção, seu oposto $^{173}$.

Quanto à virtude, Montesquieu a considerava em relação à pátria, à igualdade, e não exatamente em relação à moral. Propugnava a virtude política, em que o bem coletivo era a tônica. Ao estabelecer um paralelo com os demais regimes, esclarece que

(...) O temor dos governos despóticos nasce de si mesmo, entre as ameaças e castigos; a honra das monarquias é favorecida pelas paixões e favorece-as por sua vez. Mas a virtude política é uma renúncia a si próprio, que é sempre algo muito penoso.

Monárquico e o Despótico. Para descobrir-lhes a natureza, é suficiente a idéia que deles têm os homens menos instruídos. Suponho três definições, ou antes, três fatos: um que o 'governo republicano é aquele em que o povo, como um todo, ou somente uma parcela do povo, possui o poder soberano; a monarquia é aquele em que um só governa, mas de acordo com leis fixas e estabelecidas, enquanto, no governo despótico, uma só pessoa, sem obedecer a leis e regras, realiza tudo por sua vontade e seus caprichos"” (In: Os Pensadores. Trad. Editora Bertrand Brasil. Rio de Janeiro. São Paulo: Nova Cultural, 1997, v. 1, p. 45. Título original: De l'Esprit des lois, ou du rapport que les lois doivent avoir avec la constitution de chaque gouvernement, les mouers, le climat, la religion, le commerce, etc. - $1^{\mathrm{a}}$ edição, 1748). Complementa, ainda, Montesquieu: "Quando, numa república, o povo como um todo possui o poder soberano, trata-se de uma Democracia. Quando o poder soberano está nas mãos de uma parte do povo, trata-se de uma Aristocracia" (Op. cit., p. 45).

171 É de se lembrar que o termo república vem do latim republica, que se origina dos termos res publica e que significa coisa pública.

172 A República. $2^{\mathrm{a}}$ ed. São Paulo: Publifolha, 2008, pp. 43-45.

173 Renato Janine Ribeiro. A República. $2^{\mathrm{a}}$ ed. São Paulo: Publifolha, 2008, pp. 46, 50, 51 e 60. 
Podemos definir esta virtude como o amor pelas leis e pela pátria. Este amor, exigindo sempre a supremacia do interesse público sobre o interesse particular, produz todas as virtudes individuais; elas nada mais são do que esta supremacia. ${ }^{174}$

Renato Janine Ribeiro afirma que, modernamente, o princípio da república deixa de ser o da virtude e passa a ser o do interesse, elemento voltado para a realização pessoal. Esse interesse, no entanto, deve ser orientado para se apresentar de forma equilibrada, com o fim último de alcançar a estabilidade do cidadão, mas respeitando o patrimônio social ${ }^{175}$.

Bem por isso, a corrupção ganha outro sentido nos dias atuais, representando a utilização da coisa pública para se alcançar fins privados. Essa é a situação em que o interesse, ou seja, a busca pela realização pessoal ultrapassa os limites ideais e acaba por atingir o bem comum. A ocorrência generalizada dessa situação põe em risco a existência da própria república.

\subsubsection{A corrupção e a democracia}

O termo democracia vem do grego demokratía (demos, que significa povo e kratos, o qual indica poder) e representa literalmente o poder do povo. A concepção de democracia leva ao entendimento de que o poder deve ser exercido por representantes escolhidos pelo próprio povo e subordinados a ele. Quanto maior a participação popular, tanto maior será o controle exercido em face dos agentes públicos, responsáveis, em última análise, pelo alcance do bem comum.

Não por acaso, Regis Fernandes de Oliveira destaca que "quanto mais forte a dose de democracia, menos possibilidade têm os comportamentos ilícitos de prosperar. Nas ditaduras é que ela pode germinar e, sub-repticiamente, estender seus tentáculos em todas as áreas, minando a Administração Pública"176.

A afirmação, porém, não pode levar à conclusão de que a democracia seria a única solução para o enfrentamento da corrupção. Na verdade, deve-se inclusive considerar que, "no Estado democrático moderno, é bastante elevada a quantidade de postos de poder

174 Do Espírito das Leis (primeira parte, livro quarto, capítulo V). In: Os Pensadores. Trad. Editora Bertrand Brasil. Rio de Janeiro. São Paulo: Nova Cultural, 1997, v. 1, p. 75. Título original: De l'Esprit des lois, ou du rapport que les lois doivent avoir avec la constitution de chaque gouvernement, les mouers, le climat, la religion, le commerce, etc. - $1^{\mathrm{a}}$ edição, 1748.

175 A República. 2a ed. São Paulo: Publifolha, 2008, pp. 60, 61, 68 e 77. Para uma análise da República em relação à Constituição brasileira, ver Geraldo Ataliba (República e Constituição. $2^{\mathrm{a}}$ ed. atual. Rosolea Miranda Folgosi. São Paulo: Malheiros Editores, 2001).

176 Curso de direito financeiro. São Paulo: Editora Revista dos Tribunais, 2006, p. 226. 
público cuja ocupação é submetida à escolha de um eleitorado universalizado" e, dessa forma, "há um aumento nas oportunidades de transações ilegítimas entre o público e o privado e, de outro, a ausência de restrições ao acesso aos lugares de poder" ${ }^{\text {"177 }}$. Depreendese, então, que deve haver um controle da corrupção e um ataque às situações em que ela é incentivada, inclusive na esfera dos representantes eleitos pelo povo ${ }^{178}$.

O problema é que a incapacidade do Estado em controlar ou impedir a ocorrência de práticas corruptas acaba por gerar uma descrença nas próprias instituições democráticas.

A presença da corrupção desemboca numa reduzida atuação política da sociedade, atenuando o espírito republicano dos cidadãos. Advém, com isso, um círculo vicioso, favorecendo o surgimento de "políticos profissionais", os quais se perpetuam no poder e não representam o povo, mas uma elite política, gerando maior desconfiança dos cidadãos e maior distanciamento destes da esfera política. O Estado, então, mergulha numa crise de legitimidade, seja pela incapacidade de gerar políticas para o bem comum, prática dificultada pela corrupção, seja pela desconfiança da sociedade em relação às funções estatais $^{179}$.

\subsubsection{A corrupção, o desenvolvimento econômico e social, a ética e o papel do Estado}

Dados mundiais da organização "Transparência Internacional", obtidos por meio de entrevista a 63.199 pessoas em sessenta países e territórios no ano de 2007, demonstram as trágicas consequências que a corrupção traz à sociedade, à economia e ao $\operatorname{Estado}^{180}$ : a) são

177 Wanderley Guilherme dos Santos. Democracia. In: AVRITZER, Leonardo; BIGNOTTO, Newton; GUIMARÃES, Juarez; STARLING, Heloisa Maria Murgel (org.). Corrupção: ensaios e críticas. Belo Horizonte: Editora UFMG, 2008, p. 126. O mesmo autor complementa: "São as facilidades ou dificuldades de acesso ao poder que distinguem o poder absolutista do oligárquico e este do democrático. Garantido o direito de abordagem, escolha e participação no poder público, transferem-se para o conjunto da sociedade os atributos do poder absolutista. Na mesma extensão em que se distribui o poder, distribuem-se as oportunidades de corrupção nele implícitas. Por isso, a corrupção democrática identifica a face deteriorada do direito de participação popular na constituição e exercício do poder político, tal como Aristóteles havia antecipado" (Op. cit., p. 126).

178 Nesse sentido, Fernando Filgueiras (Corrupção, democracia e legitimidade. Belo Horizonte: Editora UFMG, 2008, p. 160) expõe: "Como os termos da ética de responsabilidade circunscrevem-se na ação política, o essencial é controlar os incentivos à ação corrupta ou corruptora por parte dos agentes políticos. A relação entre democracia e corrupção, dessa forma, está assentada em construir mecanismos de controle sobre a ação política na direção da crescente responsabilização dos políticos diante do eleitorado, tendo em vista a intencionalidade da ação".

179 Fernando Filgueiras. Corrupção, democracia e legitimidade. Belo Horizonte: Editora UFMG, 2008, pp. 146-167 (passim).

180 Transparency Internacional, Departamento de Investigación y Políticas, "Informe sobre el Barômetro Global de la Corrupción de Transparency Internacional 2007”, Berlim, 6 dez. 2007. Disponível em: 
os pobres, tanto os de países desenvolvidos quantos os daqueles altamente industrializados, os mais prejudicados pela corrupção; b) são justamente os pobres os mais pessimistas em relação à expectativa de melhoria futura do grau de corrupção; c) cerca de uma em cada dez pessoas no mundo já teve que pagar suborno; d) a prática do suborno estende-se às relações com a polícia, a justiça e os serviços de registro e de fiscalização; e) de maneira geral, os partidos políticos, o parlamento, a polícia e o judiciário são tidos como as instituições mais corruptas da sociedade; f) em geral, a metade dos entrevistados acreditam que em seus respectivos países a corrupção aumentará nos próximos três anos; g) a metade dos entrevistados creem que são ineficazes os esforços empreendidos pelos governantes de seus respectivos países para extirpar a corrupção.

Depreende-se da pesquisa que a corrupção acaba por atingir toda a sociedade, pois aumenta a desigualdade na distribuição de riqueza e mina a legitimidade do governo que se mostra incapaz de combatê-la, inclusive quando essa corrupção se encontra incrustada no seio de suas instituições-chave (justiça, administração pública, polícia, parlamento, para citar alguns exemplos).

De fato, frequentemente se observa nos jornais e em estudos nacionais e estrangeiros o valor que o fator corrupção representa como verdadeiro empecilho para o progresso dos países. Observe-se, nesse sentido, que o aumento da corrupção inibe a quantidade de investimentos no país, incentiva a informalidade, provoca a evasão de divisas, diminui a margem de lucro das empresas, reduz a quantidade de recursos públicos, enfim, contribui para baixar o nível de crescimento do Estado. Para citar um exemplo, importante mencionar que, no ano de 2005, estimou-se o custo médio da corrupção no Brasil em US\$10,7 bilhões, ou seja, cerca de R \$26,2 bilhões, o que correspondia, à época, a $1,35 \%$ do produto interno bruto (PIB) do país ${ }^{181}$.

A relação crescimento econômico e corrupção é tão relevante que o Banco Mundial vem se preocupando com a questão, adotando programas para a superação do problema, como, por exemplo, investimentos em áreas que tenham como objetivo a reforma judicial, o aperfeiçoamento da função pública, a descentralização da prestação de serviços públicos, a liberdade de informação e o aprimoramento dos meios de comunicação. Além disso,

www.transparency.org/content/download/27458/413669/file/GCB_2007_report_esp_02-12-2007.pdf. Acessado em 28.11.2008.

181 Federação das Indústrias do Estado de São Paulo (FIESP), "Relatório Corrupção: custos econômicos e propostas de combate", São Paulo, 5 dez. 2006. Disponível em: http://bvc.cgu.gov.br/handle/123456789/937. Acessado em 28.11.2008. 
outra medida adotada pelo Banco Mundial consiste na restrição de financiamentos a Estados com alto grau de corrupção, de forma a incentivar que os governantes desses países, carentes de recursos externos, adotem práticas de combate ao referido mal.

A questão que surge é diante da existência de países que, embora com níveis altos de corrupção, apresentam um desenvolvimento econômico significativo, exemplos da Indonésia, Tailândia e Coreia. A partir desses dados, poder-se-ia questionar se a corrupção seria realmente um motivo de preocupação ${ }^{182}$. Susan Rose-Ackerman apresenta dois fundamentos relevantes para afastar a ideia de que o comportamento corrupto deve ser aceito, ainda que produza certos níveis de desenvolvimento:

Primeiro: países com corrupção sistêmica que, apesar de tudo, obtiveram crescimento econômico satisfatório, correm o risco de cair em uma espiral decrescente. A corrupção pode virar uma bola de neve de modo que produza comissões ilegais mais elevadas até que o crescimento seja comprometido. ${ }^{183}$ A tolerância à corrupção, que encobre os pontos problemáticos do sistema e desvia de $5 \%$ a $10 \%$ do valor dos projetos públicos, pode gerar pressões para que o valor seja aumentado para $15 \%$ ou $20 \%$. Exatamente o mesmo crescimento que permitiu a corrupção no passado pode produzir uma mudança das atividades produtivas para uma luta improdutiva por benefícios oriundos de cargos públicos, prejudicando, assim, o crescimento e os investimentos futuros. Sem uma reforma procedimental consciente a corrupção não será algo a partir do que um determinado país vá 'crescer'.

Segundo: o crescimento econômico não é a única meta digna de ser almejada. A corrupção também tende a distorcer a alocação dos benefícios econômicos, favorecer aqueles que têm em detrimento daqueles que não têm, e levar a uma distribuição de renda menos igualitária.

182 Susan Rose-Ackerman (A economia política da corrupção. In: ELLIOTT, Kimberly Ann (org.). A corrupção e a economia global. Tradução de Marsel Nascimento Gonçalves de Souza. Brasília: Editora Universidade de Brasília, 2002, p. 61. Título original: Corruption and the global economy.

183 A "bola de neve" e as "comissões ilegais" citadas por Susan Rose-Ackerman podem ser bem observadas num exemplo simples mencionado por Avinash K. Dixit e Barry J. Nalebuff (Pensar estratégicamente: un arma decisiva em los negócios, la política y la vida diaria. Tradução de Ana Varela e Alicia Valls. Barcelona: Antoni Bosch, 1992, pp. 27-28. Título original: Thinking Strategically. The Competitive Edge in Business, Politics and Everyday Life): "Em uma grande frota de táxis um menino tem a responsabilidade de distribuir os táxis aos diferentes motoristas. A frota tem alguns carros bons e outros que são obsoletos. $\mathrm{O}$ encarregado pode utilizar seu poder de decisão para conseguir uma propina de cada motorista. $\mathrm{O}$ motorista que se negue a pagar pode estar certo de que lhe será destinado um obsoleto, enquanto que, aos que cooperam, lhes é permitido participar do sorteio dos táxis restantes. O encarregado se enriquece, apesar de que os motoristas, como grupo, terminam com o mesmo conjunto de carros que teriam possuído se ninguém tivesse utilizado o suborno. Se atuassem em acordo, provavelmente poderiam pôr fim a esse tipo de atividades. O problema está em conseguir organizar o movimento. E a questão não é tanto o prêmio que o encarregado pode dar aos que o subornam, mas o severo castigo que se pode impor aos que não o fazem" (tradução livre do autor). No original: "En una flota grande de taxis, a menudo hay un encargado de asignar los taxis a los diferentes conductores. La flota tiene algunos coches buenos y otros que son carracas. El encargado puede utilizar su poder de decisión para conseguirse una propinilla de cada conductor. El conductor que se niegue a pagar puede estar seguro de que le tocará una carraca, mientras que a los que cooperan se les permite participar en el sorteo de los taxis restantes. El cargado se enriquece, mientras que los conductores como grupo terminan con el mismo conjunto de coches que hubieran tenido si nadie hubiera utilizado el soborno. Si actuasen de acuerdo, probablemente podrían poner fin a este tipo de actividades. El problema está en conseguir organizar el movimiento. Y la cuestión no es tanto el premio que el encargado pueda dar a los que le sobornan, como el severo castigo que puede imponer a los que no lo hacen”. 
Em casos extremos ela pode até minar a estabilidade política (...). Mesmo quando a corrupção é uma forma de se contornar políticas governamentais excessivamente restritivas, ainda assim ela é uma opção inferior. Sobretudo para economias emergentes e em transição, um registro respeitável de crescimento não deveria ser utilizado para justificar a perpetuação de relações ineficientes e injustas nos setores público e privado.

Kimberly Ann Elliot afirma que há quem defenda que a corrupção pode se tornar uma alternativa a certas deficiências do aparato estatal, tal como a burocracia. Segundo ela, mesmo nessa hipótese, a argumentação não prospera, uma vez que, como consequência final, os resultados da corrupção são geralmente prejudiciais ${ }^{184}$. Até naquelas hipóteses em que a corrupção é utilizada como meio de proporcionar uma eficiência maior do Estado, não haveria como restringi-la somente a esses casos; questiona a autora: "quando os benefícios do governo são distribuídos, o que garante que o suborno vá apenas deixar de lado a papelada da burocracia e não desviará benefícios daqueles indivíduos 'merecedores' para aqueles que dispõe[m] de recursos financeiros?"185.

Outro ponto merecedor de análise é a questão do desenvolvimento social por vezes proporcionado pela corrupção. Exemplifica Regis Fernandes de Oliveira que "é comum que Chefes do Executivo sintam-se estimulados a construir obras públicas, uma vez que aumentam os benefícios de que irá usufruir percentualmente, através do 'pedágio', isto é, da propina que lhes será encaminhada"; porém, "com a realização da obra, beneficiam-se o transporte, os prédios públicos e residências que venham a ter as vias públicas asfaltadas etc." ${ }^{186}$ No tocante a esses aspectos, os mesmos argumentos econômicos contra a tolerância em relação à corrupção poderiam ser aqui reiterados, mas é importante, também, uma breve menção à questão ética ou, como menciona o próprio autor, uma análise quanto aos "benefícios privados, corrupção pública, que pode levar, no entanto, ao desenvolvimento social" $" 187$.

184 A corrupção como um problema de legislação internacional: recapitulação e recomendações. In: ELLIOTT, Kimberly Ann (org.). A corrupção e a economia global. Tradução de Marsel Nascimento Gonçalves de Souza. Brasília: Editora Universidade de Brasília, 2002, p. 271. Título original: Corruption and the global economy.

185 ELLIOTT, Kimberly Ann Elliott. A corrupção como um problema de legislação internacional: recapitulação e recomendações. In: ELLIOTT, Kimberly Ann (org.). A corrupção e a economia global. Tradução de Marsel Nascimento Gonçalves de Souza. Brasília: Editora Universidade de Brasília, 2002, p. 272. Título original: Corruption and the global economy).

186 Curso de direito financeiro. São Paulo: Editora Revista dos Tribunais, 2006, p. 236.

187 Curso de direito financeiro. São Paulo: Editora Revista dos Tribunais, 2006, p. 236. 
A ética pode ser definida como "a ciência ou filosofia que fará a eleição das melhores ações tendo como horizonte o interesse coletivo, universal" ${ }^{\text {"188 }}$. O comportamento ético não deve ter como referência o indivíduo, mas sim a sociedade. É por esse motivo que determinada conduta, para ser considerada ética, deve ser averiguada em parâmetros mais abrangentes, ou seja, deve-se provar que a ação não coloca em risco a coletividade ${ }^{189}$.

A economia tem como sustentação os princípios éticos, sob pena de completa desorganização, instabilidade da ordem social e risco à sobrevivência. De outro lado, a excessiva preocupação com a moralidade cívica, em detrimento de outros valores, tais como a liberdade e a autonomia dos cidadãos, põe em risco a continuidade da vida em comum $^{190}$ e a eficiência econômica ${ }^{191}$. Deve haver, dessa forma, um equilíbrio entre a ética e a liberdade individual, com vistas a alcançar o interesse coletivo.

A relação entre ética e economia pode ser estudada a partir da obra de Bernard de Mandeville denominada "A fábula das abelhas; ou vícios privados, benefícios públicos" ${ }^{\text {, }}$ em que analisa uma sátira anônima, publicada em forma de poema em 2 de abril de 1705, intitulada "A colméia rumorosa ou a redenção dos canalhas"193. A fábula retrata a vida

188 Guilherme Assis de Almeida e Martha Ochsenhofer Christmann. Ética e direito: uma perspectiva integrada. São Paulo: Atlas, 2002, p. 14. José Renato Nalini afirma que a ética tem como objeto a moral, que constitui um dos aspectos do comportamento humano. Enquanto a ética representa uma ciência dos costumes, a moral é o objeto dessa ciência (Ética geral e profissional. $4^{\mathrm{a}}$ ed. rev., atual. e ampl. São Paulo: Editora Revista dos Tribunais, 2004, pp. 26 e 27). Henrique Cláudio de Lima Vaz ensina que a ética é a ciência do ethos (costume) e "repousa, assim, sobre a pressuposição de que à theoría é inerente uma virtude educadora segundo a qual, tendo como objeto o Bem, ela torna bom aquele que a exerce; ou ainda, ela realiza a semelhança (omoíosis) entre o sujeito da theoría e o seu objeto" (Ética e Direito. São Paulo: Landy Editora - Edições Loyola, 2002, p. 58).

189 Peter Singer (Ética prática. Tradução de Jefferson Luiz Camargo. $3^{\text {a }}$ ed. São Paulo: Martins Fontes, 2002, p. 18. Título original: Practical Ethics) esclarece esse ponto ao afirmar: "Se devemos aceitar que uma pessoa está vivendo de acordo com padrões éticos, isso deve se dar com base num certo tipo de justificativa. Por exemplo, uma justificativa exclusivamente em termos de interesse pessoal não pode ser aceita. Quando, ao tramar a morte de Duncan, Macbeth admite que só 'ambições grandiosas' o induzem a fazê-lo, está admitindo que o ato não pode ser justificado eticamente. 'Para que eu possa ser o rei em seu lugar' não é uma frágil tentativa de justificação ética para o assassinato; não é, de modo algum, o tipo de razão que vale como justificativa ética. Para serem eticamente defensáveis, é preciso demonstrar que os atos com base no interesse pessoal são compatíveis com princípios éticos de bases mais amplas, pois a noção de ética traz consigo a idéia de alguma coisa maior que o individual. Se vou defender a minha conduta em bases éticas, não posso mostrar apenas os benefícios que ela me traz. Devo reportarme a um público maior".

190 Eduardo Giannetti. Vícios privados, benefícios públicos?: a ética na riqueza das nações. São Paulo: Companhia das Letras, 1993, p. 95.

191 Eduardo Giannetti. Vícios privados, benefícios públicos?: a ética na riqueza das nações. São Paulo: Companhia das Letras, 1993, p. 127.

192 Título original: The Fable of the Bees: or Private Vices, Public Benefits. Não há versão em português desta obra de Bernard Mandeville; no entanto, pode ser encontrada a versão em espanhol traduzida por José Ferrater Mora (La fabula de las abejas o los vicios privados hacen la prosperidad pública. México: Fondo de Cultura Econômica, 1982), com comentários crítico, histórico e explicativo de F. B. Kaye.

193 Curioso notar que não foi Bernard de Mandeville o primeiro a realizar a associação entre vícios privados e benefícios públicos. Na verdade, já no século XVI, Michel de Montaigne discutia a função dos vícios 
numa colmeia, que era composta por dois grupos: os canalhas dissimulados, os quais se comportavam como honestos, mas que, quando possível e avaliado o risco, agiam de má-fé com clientes e fornecedores; e os canalhas assumidos, os quais visivelmente viviam da prática de atos ilegais ${ }^{194}$. A colmeia conseguia transformar esses vícios em benefícios públicos, proporcionando um próspero e efetivo desenvolvimento econômico; o egoísmo, o prazer individual e imediato, bem como a corrupção existentes na colmeia serviam de estímulo à economia ${ }^{195}$. Descontentes com a degradação moral presente na sociedade, as abelhas desejam cada vez mais um ambiente honesto. Quando seus desejos são atendidos e os vícios são expurgados mediante a intervenção de Júpiter, a economia sofre um declínio, acarretando um desenvolvimento inexpressivo, apesar do ambiente virtuoso na colmeia: há

na sociedade. Nesse sentido, afirmava o filósofo no Livro III, Capítulo I (Do útil e do honesto), de sua obra: "Como quer que encaremos este nosso mundo, vemo-lo cheio de imperfeições; nada é inútil entretanto na natureza, nem mesmo as inutilidades. Nada existe que não tenha sua aplicação. Nosso ser é um aglomerado de qualidades que são ao mesmo tempo defeitos. A ambição, o ciúme, a inveja, a superstição e o desespero estão em nós e tão naturalmente alojados que até nos próprios animais se encontram. Mesmo a crueldade, esse vício antinatural, habita em nós, pois paralelamente à compaixão experimentamos uma volúpia agridoce, e doentia, ao espetáculo do sofrimento alheio. Sentem-na as próprias crianças: 'É doce, durante a tempestade, contemplar os navios que lutam contra o furor das ondas' [Lucrécio]. Quem extirpasse o germe dos maus sentimentos do coração do homem destruiria nele as condições essenciais à vida. Da mesma forma, em todas as administrações existem cargos necessários que são abjetos, detestáveis. Os vícios aí têm sua função, e servem para soldar os diversos elementos da sociedade, como o veneno se utiliza na conservação de nossa saúde. Se são desculpáveis, porque o interesse comum os exige, deixemos que os pratiquem os cidadãos mais enérgicos, cuja vontade de salvar o país leva ao sacrifício da honra e da consciência, como levava outrora heróis a sacrificarem a vida. Nós, mais fracos, fiquemos com os papéis mais fáceis e menos arriscados. O interesse público exige que se traia e mate; abdiquemos em benefício de indivíduos mais obedientes e acomodatícios.

[...] Mas seria desconhecer a realidade não dar à malandragem o mérito que lhe cabe; sei que não raro presta serviços e é necessária em mais de uma ocasião. Há defeitos lícitos como há boas ações ilícitas". (Michel de Montaigne. Ensaios. In: Os Pensadores. Tradução de Sérgio Milliet. São Paulo: Nova Cultural, 1996, pp. 141-142, 146-147, v. 2. Título original: Essais)

194 Eis o seguinte excerto da fábula (Bernard Mandeville. La fabula de las abejas o los vicios privados hacen la prosperidad pública. Tradução de José Ferrater Mora. México: Fondo de Cultura Econômica, 1982, p. 12. Título original: The Fable of the Bees: or Private Vices, Public Benefits): "Chamavam a estes de canalhas, mas salvo pelo nome/os sérios e trabalhadores eram iguais:/todo trabalho e dignidade tem sua trapaça,/não existe profissão sem engano" (tradução livre do autor). No original: "Bribones llamaban a éstos, mas salvo el mote,/los serios e industriosos eran lo mismo:/todo oficio y dignidad tiene su tramposo,/no existe profesión sin engaño".

195 Nesse sentido é o texto da fábula (Bernard Mandeville. La fabula de las abejas o los vicios privados hacen la prosperidad pública. Tradução de José Ferrater Mora. México: Fondo de Cultura Econômica, 1982, pp. 14-15. Título original: The Fable of the Bees: or Private Vices, Public Benefits): “Assim, o vício estava em toda parte,/embora todo o conjunto fosse um Paraíso;/adulados na paz, temidos na guerra,/eram estimados pelos estrangeiros/e dispersavam em sua vida e riqueza/o equilíbrio das demais colméias./Tais eram as bênçãos daquele Estado:/seus pecados colaboravam para torná-lo grande;/e a virtude, que da política/havia aprendido mil astúcias,/pela feliz influência desta/tornou-se substância do vício; e desde então/o pior elemento da multidão,/fazia algo para o bem comum" (tradução livre do autor). No original: "Así pues, cada parte estaba llena de vícios,/pero todo el conjunto era un Paraíso;/adulados en la paz, temidos en la guerra,/eran estimados por los extranjeros/y disipaban en su vida y riqueza/el equilibrio de los demás panales./Tales eran las bendiciones de aquel Estado:/sus pecados colaboraban para hacerle grande;/y la virtud, que de la política/había aprendido mil astucias,/por la feliz influencia de ésta/hizo migas con el vicio; y desde entonces/aun el peor de la multitud,/algo hacía por el bien común". 
o esmorecimento do comércio e da indústria, o enfraquecimento do setor público e o aumento do desemprego ${ }^{196}$. A fábula, embora utilize uma comparação demasiadamente exagerada, pretende demonstrar que o excesso moral pode produzir a estagnação econômica $^{197}$.

Eduardo Giannetti se contrapõe à tese de Mandeville argumentando que, embora a absoluta virtude seja prejudicial à economia, também o vício pleno se mostra nefasto ${ }^{198}$. Segundo ele, "a ordem social e a ordem do mercado estão ancoradas numa infra-estrutura ética. Para escapar do naufrágio, nenhuma das duas pode prescindir dela"199. Aliás, conforme ressalta José Renato Nalini, "o mundo econômico não pode se distanciar do mundo moral" 200 .

Daí é que se propõe a defesa do mínimo legal, estabelecendo-se os limites entre o que é permitido e o que não se pode tolerar na economia de mercado, tudo como forma de

196 Assim consta da fábula (Bernard Mandeville. La fabula de las abejas o los vicios privados hacen la prosperidad pública. Tradução de José Ferrater Mora. México: Fondo de Cultura Econômica, 1982, p. 14-15. Título original: The Fable of the Bees: or Private Vices, Public Benefits): “À medida em que o orgulho e o luxo se enfraqueciam,/também iam abandonando os mares pouco a pouco./Agora não mercadores, mas companhias inteiras,/fábricas fechavam completamente./Toda arte e ofício eram abandonados;/a saciedade, ruína da indústria,/os fazia admirar o estoque caseiro/e não buscar nada mais, nem desejá-lo" (tradução livre do autor). No original: "A medida que el orgullo y el lujo desmedraban,/también iban abandonado los mares poco a poco./No ya mercaderes, sino compañías enteras,/ cerraban factorías completamente./Todo arte y oficio yacían olvidados;/la saciedad, ruina de la industria,/les hacía admirar la alacena casera/y no buscar nada más, ni desearlo”.

197 O próprio Bernard de Mandeville (La fabula de las abejas o los vicios privados hacen la prosperidad pública. Tradução de José Ferrater Mora. México: Fondo de Cultura Econômica, 1982, p. 6. Título original: The Fable of the Bees: or Private Vices, Public Benefits), no prefácio da obra, esclarece o objetivo da fábula: "O principal propósito da fábula (como brevemente é explicado na moral) não é outro senão mostrar a impossibilidade de se desfrutar de todas as mais elegantes comodidades que oferece a vida numa nação laboriosa, rica e poderosa, e ao mesmo tempo receber as bênçãos da virtude e inocência próprias de uma idade de ouro; esta é a razão que me impulsiona a expor a insensatez e necessidade dos que, desejosos de ser um povo opulento e próspero, e extraordinariamente ávidos de todos os benefícios que isso pode lhes proporcionar, vão sempre murmurando e clamando ao mesmo tempo contra esses vícios e inconveniências que, desde o princípio do mundo até os dias atuais, foram inseparáveis de todos os reinos e Estados famosos pelo seu poderio, riqueza e cultura". (tradução livre do autor). No original: "El principal propósito de la fábula, pues (como brevemente se explica en la moraleja), no es otro que mostrar la imposibilidad de disfrutar de todas las más elegantes comodidades que ofrece la vida en una nación industriosa, rica y poderosa; y al mismo tiempo recibir la bendiciones de la virtud e inocencia propias de una edad de oro; ésta es la razón que me impulsa a exponer la insensatez y necedad de los que, deseosos de ser un pueblo opulento y próspero, y extraordinariamente codiciosos de todos los beneficios que éste pueda proporcionarles, van siempre murmurando y clamando al mismo tiempo contra estos vicios e inconveniencias que, desde el principio del mundo hasta el presente día, fueron inseparables de todos los reinos y Estados famosos a la vez por su poder, riqueza y cultura".

198 Vícios privados, benefícios públicos?: a ética na riqueza das nações. São Paulo: Companhia das Letras, 1993, p. 144.

199 Vícios privados, benefícios públicos?: a ética na riqueza das nações. São Paulo: Companhia das Letras, 1993, p. 145.

200 Ética geral e profissional. $4^{\mathrm{a}}$ ed. rev., atual. e ampl. São Paulo: Editora Revista dos Tribunais, 2004, p. 77. 
contraposição ao egoísmo ético ${ }^{201}$, teoria que defende a conduta individual egoísta despida de preocupações morais - como meio para alcançar o bem comum ${ }^{202}$.

O Estado tem o papel de, justamente, impor, garantir e defender esse mínimo legal, motivo pelo qual a falta de exercício dessa função e a ausência de conduta ética dos governantes e dos que exercem cargos no setor público provocam a deterioração da economia, afastando a confiança do setor privado nas regras de mercado e no próprio Estado $^{203}$.

De fato, a falta de credibilidade nas atribuições exercidas pelo Estado representa não só o primeiro passo para o completo descontrole da economia, como também o motivo ensejador de distorções nas relações sociais, provocando a médio e longo prazos deficiências e percalços importantes no desenvolvimento dos países. Além disso, importante frisar que o sentimento de justiça social é incompatível com a presença de governantes que não respeitam e proporcionam o exercício da ética em suas funções; ao contrário, a prática de atos que visam somente o interesse próprio dos que governam põe à margem a sociedade, desvirtuando o objetivo primordial do Estado, que é a busca do bem comum.

201 Nesse sentido, Eduardo Giannetti (Vícios privados, benefícios públicos?: a ética na riqueza das nações. São Paulo: Companhia das Letras, 1993, pp. 145-146) esclarece: "O mínimo legal da economia de mercado inclui, além da legislação criminal básica, regras que estabelecem a fronteira entre o que é lícito e o que é ilícito na atividade econômica. Sabotar as operações da empresa rival ou subornar o seu gerente de marketing são violações das regras mínimas da competição. Mas manter para si (ou patentear) um segredo industrial ou atrair o tal gerente oferecendo um salário mais alto fazem parte das regras do jogo, embora suas conseqüências para a empresa rival possam ser muito piores do que no primeiro caso. $\mathrm{O}$ mínimo legal da ordem do mercado - direitos de propriedade bem definidos, liberdade e garantia de execução de contratos e prevenção de práticas anti-competitivas - tem como objetivo básico barrar as tentativas dos agentes econômicos de viver às custas dos demais, colhendo o que não plantaram".

Importante, nesse ponto, a observação de Eduardo Giannetti (Vícios privados, benefícios públicos?: a ética na riqueza das nações. São Paulo: Companhia das Letras, 1993, pp. 133-134): "Uma posição teórica muito distinta da smithiana, e que acabou em larga medida dominando a ciência econômica no século XX, é a tese do egoísmo ético. Trata-se aqui da afirmação do auto-interesse governado pelo motivo monetário não tanto como uma regularidade empírica, mais ou menos próxima dos fatos observáveis, mas como uma prescrição - como um ideal normativo de conduta para o indivíduo - tendo em vista os objetivos de promover a eficiência produtiva e alocativa da economia e de maximizar o nível de bem-estar material da sociedade".

203 Eduardo Giannetti. Vícios privados, benefícios públicos?: a ética na riqueza das nações. São Paulo: Companhia das Letras, 1993, pp. 146-148. 


\subsection{Há relação entre o desvio de recursos públicos e o federalismo fiscal?}

\subsubsection{O desvio de recursos públicos e suas consequências para as funções fiscais}

A corrupção e as demais causas de desvio de recursos, aqui tratadas (rent-seeking, patrimonialismo, clientelismo e coronelismo), têm como uma das primeiras consequências o transviamento dos objetivos da função pública, impedindo que o bem comum seja alcançado em níveis eficientes (e suficientes) pelo Estado.

No caso da corrupção, por exemplo, a relação existente entre corruptos, corruptores e os beneficiados com sua prática indica a existência de uma associação no seio da qual ocorre uma transferência de renda, mas com recursos provenientes da própria sociedade. Percebe-se, então, a incidência de uma função distributiva imprópria, em que não é o Estado (ou uma de suas unidades federadas) que comanda a distribuição de recursos de forma universal, mas sim pessoas pertencentes ao próprio aparato estatal, as quais possuem como objetivo a satisfação de interesses particulares ${ }^{204}$.

O problema é que essa furtiva transferência de recursos ocorre em duplo prejuízo à sociedade. Em primeiro lugar, o desvio de renda para o proveito exclusivo de pessoas ou grupos acarreta um empobrecimento - proporcional e quase instantâneo - do Estado, que se vê impedido de utilizar os recursos públicos para as funções que lhe são inerentes. De outro lado, além da ocorrência do desvio, percebe-se que, usualmente, o dinheiro empregado para fins particulares não repercute, sequer indiretamente, em benefício à sociedade; ao contrário, muitas vezes os recursos são utilizados em objetivos antagônicos às necessidades da população (fomento do crime organizado, direcionamento de licitações a empresas inaptas, por exemplo). Nesses casos, a função alocativa do Estado é prejudicada ou obstaculizada, uma vez que o dinheiro público é aplicado em atividades ineficientes ou incapazes de proporcionar ganho à sociedade. Em algumas situações, "os

204 Nesse sentido, Kimberly Ann Elliott (A corrupção como um problema de legislação internacional: recapitulação e recomendações. In: ELLIOTT, Kimberly Ann (org.). A corrupção e a economia global. Tradução de Marsel Nascimento Gonçalves de Souza. Brasília: Editora Universidade de Brasília, 2002, p. 278. Título original: Corruption and the global economy) exemplifica que as obras "faraônicas" não trazem benefícios ao bem comum mas, por outro lado, enriquecem os agentes públicos e empreiteiras. Susan Rose-Ackerman (A economia política da corrupção. In: ELLIOTT, Kimberly Ann (org.). A corrupção e a economia global. Tradução de Marsel Nascimento Gonçalves de Souza. Brasília: Editora Universidade de Brasília, 2002, p. 78. Título original: Corruption and the global economy), por sua vez, confirma as consequências da corrupção no tocante à função distributiva: "Uma fatia maior dos ganhos é acumulada por vencedores de licitações e por funcionários públicos mais em um processo corrupto de contratação e de privatização do que em um sistema idôneo. Uma parcela da riqueza do país é distribuída para pessoas do sistema e para concorrentes corruptos, o que contribui para as desigualdades de renda. Para cobrir os altos preços de contratos, bem como as decepcionantes receitas geradas pelas privatizações, o governo se vê obrigado a aumentar impostos ou a cortar gastos”. 
funcionários corruptos do governo podem vir a preferir aqueles tipos de despesas que os permitam coletar subornos e manter-se em segredo" ${ }^{205}$. Vale dizer, em todos os casos, a qualidade do gasto público resta prejudicada ${ }^{206}$.

Como exemplos de práticas que retratam a ineficiência do destino dos recursos públicos (em prejuízo à função fiscal alocativa), bem como a nefasta distribuição de rendas em prejuízo à sociedade (ocasionando dano à função fiscal distributiva), podem ser citados: a) fraude em licitações, com o favorecimento de empresas que não possuem condições técnicas para a realização de obras e serviços; b) superfaturamento de preços dos contratos, com o intuito de beneficiar empresas que possuem relação viciosa com agentes da Administração Pública, os quais normalmente recebem propinas para a realização desses atos; c) transferência ilegal de recursos públicos a pessoas ou entidades privadas, cessão essa frequentemente travestida em contratos aparentemente legítimos no tocante ao seu aspecto formal; d) tolerância dos entes federados no exercício do seu poder de polícia, omitindo-se na fiscalização de empresas e entidades, o que acaba por gerar maiores prejuízos aos cofres públicos (a não imposição de multas, a dispensa da verificação de tributos não recolhidos, por exemplo) ou danos diretos à população (como, por exemplo, o fato de a Administração Pública municipal não impedir o funcionamento de restaurante que cause perigo à saúde pública).

Até mesmo a função fiscal estabilizadora pode ser atingida. Conforme ressalta Paolo Mauro, "ao afetar a coleta de impostos ou o volume de gastos públicos, a corrupção pode trazer consequiências orçamentárias adversas" "207. Também alega o autor que, "nos casos em que a corrupção assume a forma do uso indevido de financiamentos direcionados,

205 MAURO, Paolo. Os efeitos da corrupção sobre crescimento, investimentos e gastos do governo: uma análise de países representativos. In: ELLIOTT, Kimberly Ann (org.). A corrupção e a economia global. Tradução de Marsel Nascimento Gonçalves de Souza. Brasília: Editora Universidade de Brasília, 2002, p. 141. Título original: Corruption and the global economy.

206 A questão da ineficiência na alocação de recursos, bem como da ausência de qualidade do gasto público são descritas no trabalho de Kimberly Ann Elliott (A corrupção como um problema de legislação internacional: recapitulação e recomendações. In: ELLIOTT, Kimberly Ann (org.). A corrupção $e$ a economia global. Tradução de Marsel Nascimento Gonçalves de Souza. Brasília: Editora Universidade de Brasília, 2002, pp. 278-279. Título original: Corruption and the global economy), que expõe: "Certas decisões, como aquelas que concernem às concorrências e à infra-estrutura governamentais, somente podem ser tomadas em escalões superiores do governo. Mesmo quando determinados projetos correspondem a necessidades sociais a corrupção pode elevar os custos, piorar a qualidade ou levar a escolhas inadequadas de tecnologia. [...]

Finalmente, decisões relativas a licitações públicas podem provocar a alocação menos eficiente de recursos quando o suborno interfere na escolha do concorrente".

207 Os efeitos da corrupção sobre crescimento, investimentos e gastos do governo: uma análise de países representativos. In: ELLIOTT, Kimberly Ann (org.). A corrupção e a economia global. Tradução de Marsel Nascimento Gonçalves de Souza. Brasília: Editora Universidade de Brasília, 2002, p. 141. Título original: Corruption and the global economy. 
feitos por instituições financeiras públicas a taxas de juros abaixo do valor de mercado, a corrupção pode resultar em uma política monetária frouxa e indesejável"208.

É pelos motivos acima descritos que, invariavelmente, o exercício da corrupção e de outras causas de desvio acaba por provocar a diminuição de recursos da sociedade, prejudicando o atendimento das necessidades públicas e o desenvolvimento do próprio Estado federado.

\subsubsection{O desvio de recursos públicos e sua relação com o tipo de estrutura do federalismo} fiscal

Como visto no primeiro capítulo do presente trabalho, do ponto de vista das Finanças Públicas, a adoção do federalismo apresenta diversas vantagens:

a) a presença de níveis governamentais diversos permite uma melhor alocação de bens e serviços públicos à medida da necessidade da população circunscrita a esses diferentes níveis e de acordo com a especificidade ou magnitude da demanda ${ }^{209}$;

b) embora se reconheça que a compensação - utilizada como forma de equilibrar as externalidades geradas pelos entes subnacionais - produz maior eficácia quando é dirigida e controlada pelo poder central ${ }^{210}$, a solução dessas externalidades só se torna facilitada e com melhores resultados para a população devido à descentralização própria do federalismo. Vale dizer, a descentralização remanesce como melhor alternativa diante da centralização, que significaria o fornecimento uniforme de bens e serviços públicos pelo poder central $^{211}$;

c) a estrutura descentralizada permitiria enriquecer a participação política dos cidadãos nas decisões dos governos locais e regionais, proporcionando o aumento da transparência, da fiscalização e da democracia, fortalecendo, assim, as instituições ${ }^{212}$.

\footnotetext{
208 MAURO, Paolo. Os efeitos da corrupção sobre crescimento, investimentos e gastos do governo: uma análise de países representativos. In: ELLIOTT, Kimberly Ann (org.). A corrupção e a economia global. Tradução de Marsel Nascimento Gonçalves de Souza. Brasília: Editora Universidade de Brasília, 2002, p. 141. Título original: Corruption and the global economy.

Item 1.6.1 do presente estudo.

Item 1.6.3 deste trabalho.

211 Sebastian Freille, M. Emranul Haque e Richard Kneller. Federalism, decentralisation and corruption. (junho 2007). Disponível em http://ssrn.com/abstract=951110, acessado em 16.07.2008. No original: "Even with inter-jurisdictional externalities, decentralised provision creates a better outcome as opposed to a uniform centralized provision of public goods".

212 Item 1.2 deste estudo.
} 
Também sobre os benefícios do federalismo, Sebastian Freille, M. Emranul Haque e Richard Kneller ressaltam que a presença de um orçamento rígido incentivaria governos locais e regionais a gerarem suas próprias fontes de recursos e a se valerem delas, aumentando a eficiência, ao passo que, ao dependerem de transferências do governo central ou ao se valerem de orçamentos flexíveis, tal eficiência diminuiria ${ }^{213}$.

Diante dos argumentos acima, intuitivamente e de forma quase automática se poderia chegar à conclusão de que o federalismo fiscal seria a melhor alternativa para a diminuição do desvio de recursos públicos. Ocorre que as pesquisas empíricas sobre o assunto não chegam - pelo menos de forma unânime - a essa mesma inferência.

Nesse sentido, Daniel Treisman ${ }^{214}$ relaciona os argumentos pró e contra a adoção do federalismo como instrumento contra a corrupção e desvio de recursos. Os fundamentos que sustentam ser o sistema federativo menos corrupto propugnam que: a) a competição entre entes intergovernamentais promove a estruturação de um governo mais eficiente e honesto (B. R. Weingast); b) a competição entre níveis da federação evita subornos por parte de funcionários do governo no fornecimento de serviços públicos (A. Breton); c) a presença de força policial em cada nível governamental tende a diminuir a vulnerabilidade de medidas legais (S. Rose-Ackerman). De outro lado, os argumentos contra o federalismo podem ser assim resumidos: a) o equilíbrio de poder de representantes do governo central e dos entes subnacionais sobre certos recursos (o tributo ou o suborno em uma determinada região) conduz a uma ineficiente obtenção desses recursos (A. Shleifer e R. W. Vishny); b) como forma de superar a descentralização de poder, há a necessidade de se implantar a troca de favores (James Q. Wilson); c) num sistema descentralizado de governo existem poucas forças ou agências centralizadas que impingem a prática da honestidade (Wolfinger); d) a corrupção é mais acentuada nos entes de nível local, provavelmente em razão do relacionamento próximo entre os particulares e os funcionários públicos (R. Prud'homme e V. Tanzi) ${ }^{215}$.

213 Federalism, decentralisation and corruption. (junho 2007). Disponível em http://ssrn.com/abstract=951110, acessado em 16.07.2008. No original: "Finally, the existence of hardbudget constraints should force local and regional governments to put in effort to generate and rely on the own sources of revenues. If the local and regional governments are provided transfers from the centre or face soft budget constraints then efficiency levels will drop".

214 The Causes of Corruption: A Cross-National Study. In: Journal of Public Economics, Elsevier Science S.A., 2000, v. 76, n. 3, pp. 406-407.

215 No original: "This logic motivates two alternative arguments about the relationship between federally structured states and corruption. Some have argued that federal structure makes for more honest and efficient government by providing for competition between subjurisdictions (Weingast, 1995) or even 
Utilizando índices de percepção da corrupção, o mesmo Daniel Treisman ${ }^{216}$ elaborou pesquisa com a intenção de investigar se os países que adotam o sistema federal são menos ou mais corruptos. Com esse objetivo, estudou diversos Estados federais, tais como Canadá, Suíça, Austrália, Alemanha, Áustria, Estados Unidos, Bélgica, Espanha, Malásia, Argentina, México, Brasil, Índia, Rússia, Venezuela, Paquistão e Nigéria. Sua conclusão foi a de que, do ponto de vista do desenvolvimento econômico, os países que adotam o federalismo apresentam índices de corrupção maiores do que os dos Estados unitários.

No resultado do trabalho, no entanto, não há uma explicação categórica sobre o motivo pelo qual isso ocorre. $\mathrm{O}$ autor sugere que a competição entre diferentes níveis de governo (central e subnacionais) para a extração de suborno dos atores econômicos é o que provavelmente conduz a essa situação. Quando ambos os níveis possuem o poder de regulação, o resultado é uma grande demanda por subornos, afastando a atuação do setor privado. Nos Estados unitários tal fato é evitado em razão do controle exercido pelo poder central, que limita a atuação de funcionários públicos de entes subnacionais à obtenção de suborno. Por esse motivo, propõe Daniel Treisman que, nos países de baixo nível de desenvolvimento, mais vulneráveis à corrupção, haja cautela quanto à descentralização do poder político $^{217}$.

between levels of government (Breton, 1996) in the provision of public services for which officials could demand kickbacks. Susan Rose-Ackerman points out that: 'A federal structure in which each level has its own police force can reduce the vulnerability of any one law enforcement agency' (Rose-Ackerman, 1994, p. 27). Others suggest, by contrast, that the relatively balanced power of central and subnational officials over certain common pool resources - the tax or 'bribe' base in a given region - leads to suboptimal overextraction (Shleifer and Vishny, 1993). According to James Q. Wilson, one cause of corruption in the US system is 'the need to exchange favors to overcome decentralized authority' (Wilson, 1970, p. 304). Another political scientist argues that 'decentralized political systems are more corruptible, because the potential corrupter needs to influence only a segment of the government, and because in a fragmented system there are fewer centralized forces and agencies to enforce honesty.' A number of economists have also suggested that corruption may be greater at the local level, perhaps because of the greater intimacy and frequency of interactions between private individuals and officials at more decentralized levels (Prud'homme, 1995; Tanzi, 1995). This would have more noticeable effects in countries where a larger proportion of government takes place at subnational levels. From this, I derive two opposite hypotheses".

216 The Causes of Corruption: A Cross-National Study. In: Journal of Public Economics, Elsevier Science S.A., 2000, v. 76, n. 3, pp. 406-407.

217 The Causes of Corruption: A Cross-National Study. In: Journal of Public Economics, Elsevier Science S.A., 2000, v. 76, n. 3, pp. 440-441. No original: "Federal states were robustly perceived to be more corrupt than unitary ones, controlling for the level of economic development. This did not have anything to do with their ethnic composition, and was only in part explained by their generally larger size. I attribute this to the collective action problem for semi-autonomous central and subnational officials in deciding how much to extract in bribes from businesses that both levels have the power to regulate. Restraint by one level merely increases the pickings for the other. The likely result is suboptimally high demands for bribes that end up driving many private actors out of the market. In unitary states, more 
Hongbin Cai e Daniel Treisman, no artigo denominado "State corroding federalism"218, analisam a competição entre os governos locais na busca de rendas e a consequência desse comportamento em relação à integridade do federalismo fiscal, principalmente no tocante ao desgaste causado ao poder central. Sustentam os pesquisadores que a disputa entre os entes governamentais locais (ou regionais) pela procura de capital pode provocar a diminuição de receitas do governo central, incentivar a evasão de tributos, criar conflitos políticos sobre a distribuição de receitas, aumentar as violações regulatórias e diminuir o bem-estar da sociedade. O mérito do estudo é que ele parte de um ângulo de análise não muito debatido na doutrina, qual seja, deixa de examinar a simples "captura" do Estado pelos grupos de interesse para aprofundar o exame da questão e concluir que a disputa entre entes governamentais locais aumenta o incentivo para que os representantes do governo sejam "capturados". Admitem, porém, que essa competição tanto pode aumentar a eficiência quanto reduzi-la, dependendo em qual base o federalismo estiver estruturado, ou seja, se em instituições fortes ou, ao contrário, alicerçado sobre instituições frágeis.

A pesquisa também chama atenção à possibilidade de a competição horizontal, exercida entre os entes subnacionais, servir como um equilíbrio à competição vertical, esta exercida entre níveis governamentais diferentes para atrair empresas. Com isso, embora a frequência de transações corruptas possa não diminuir, talvez o custo agregado da corrupção, proveniente dos subornos, sofra uma redução em razão da disputa horizontal. O autor admite, porém, que tal conclusão não é definitiva, necessitando de maiores estudos a respeito $^{219}$.

effective hierarchies of control enable central officials to limit the extraction of subnational officials to more reasonable levels. If this interpretation is correct, it suggests a reason for caution in decentralizing political power in countries at low levels of development that are vulnerable to corruption".

218 Journal of Public Economics, v. 88, n. 3-4, mar. 2004, pp. 819-843.

21 Daniel Treisman. The Causes of Corruption: A Cross-National Study. In: Journal of Public Economics, Elsevier Science S.A., 2000, v. 76, n. 3, p. 441. No original: "The counterargument is that horizontal competition between regions to attract enterprises may offset the vertical competition between levels of government to extract from the same companies. While the evidence presented here suggests that on average the latter effect is stronger, it is difficult to be sure. The index of perceived corruption used in this study conflates what might be thought of as two dimensions of corruption - the frequency of corrupt transactions in a country and their aggregate cost in bribes. It is possible that while corruption might be more frequent in federal countries - explaining the statistical results - the competition between jurisdictions might keep the size of bribes low. Such questions must await further research with more precise data". 
Olivier Blanchard e Andrei Shleifer, no artigo intitulado "Federalism with and without political centralization. China versus Rússia"220 , analisam a questão do federalismo e a possibilidade de uma centralização política mais forte como forma de evitar o desvio de dinheiro público. Nessa pesquisa, do ano de 2000, estudam dois países: a China, onde a taxa de crescimento representava uma das maiores do mundo à época; e a Rússia, na qual essa taxa era uma das menores. A explicação para a discrepância entre os índices residiria no incentivo ao crescimento do setor privado; enquanto os governos locais na China estimulavam a ascensão de novas empresas, os da Rússia criavam obstáculos a esse crescimento por intermédio da tributação, regulação e corrupção.

$\mathrm{Na}$ Rússia, os incentivos para o desvio de recursos estavam diretamente relacionados ao comportamento dos governos locais e eram ocasionados por dois fenômenos: a) a "captura", em que os proprietários das antigas empresas, que dominavam a economia russa antes da transição, pressionavam os governos locais a protegê-los da competição com as novas empresas, bem como para lhes transferir rendas $^{221}$; b) a

220 Fev.-2000. MIT Dept. of Economics Working Paper n. 00-15; Harvard Institute of Economics Research Paper n. 1889. Disponível em http://ssrn.com/abstract=236127, acessado em 16.07.2008.

221 O motivo dessa pressão é bem retratado por Pertti Haaparanta e Tuuli Juurikkala (Bribes and Local Fiscal Autonomy in Rússia. (4 maio 2007). BOFIT Discussion Paper n. 12/2007. Disponível em: http://ssrn.com/abstract=1001424, acessado em 16.07.2008): "A Rússia herdou da União Soviética a estrutura de produção na qual indústrias possuem um papel importante no fornecimento de bens e serviços tais como habitação e assistência médica. O resultado foi um sistema que Ericson (1999) [Ericson R. The Post-Soviet Russian Economic System: An Industrial Feudalism?, Columbia University] chama de Feudalismo Industrial, no qual as autoridades federais são bastante frágeis em relação às autoridades regional e municipal e no qual as pessoas são presas à economia local por meio da provisão de serviços públicos.

Essas mesmas empresas ainda estão participando do fornecimento de serviços locais, tipicamente sob os cuidados do setor público ou empresas privadas especializadas numa economia de mercado. (...)

Os serviços produzidos pelas empresas não são limitados aos de âmbito social, mas incluem também partes de infra-estrutura como eletricidade e calefação. (...) Além disso, empresas podem contribuir diretamente com a comunidade local ao financiar a construção de bens sociais, estrada local ou via férrea, ao reestruturar o sistema de fornecimento de água e esgoto e assim por diante, prevenindo tributos ou outros favores do governo municipal, o qual, por sua vez, freqüentemente se dispõe a empregar nessa troca transações para evitar perda de receita tributária dos níveis governamentais superiores. Pode-se afirmar que ao se engajar nessas atividades de desvio de recursos de empresas para usos mais produtivos, o crescimento é inibido". (tradução livre do autor).

No original: "Russia inherited from the Soviet Union a production structure in which industrial enterprises played a major role in providing goods and services such as housing and medical care. The result was a system that Ericson (1999) calls Industrial Feudalism, where federal authority is quite weak relative to regional and municipal authorities and where people are tied to the local economy through the provision of public services.

These same firms are still extensively participating in the provision of local services, typically provided by the public sector or specialised private enterprises in a market economy. (...)

The services produced by firms are not limited to social ones but include parts of infrastructure like electricity and heating as well. (...) Furthermore, firms may directly contribute to the local community by financing municipal social assets, local road or rail building, the renovation of water supply and sewage systems and so on, anticipating tax or other favours from the municipal government, which is in turn often willing to engage in these barter transactions in order to avoid losing tax revenue to upper 
“competição por rendas" entre os órgãos do governo, fruto da própria desorganização administrativa russa, fazendo com que esses órgãos buscassem rendas das novas empresas, o que acabava por desencorajá-las a, legalmente, se instalar no país. Na China, esse desvirtuamento não ocorreu devido ao controle estrito do partido comunista, o qual tinha o poder de punir os governos locais quando da prática desses comportamentos. Já na Rússia, o poder central não possuía a mesma autoridade para evitar a captura ou competição por rendas e, tampouco, para estabelecer a regulamentação necessária com vistas a promover o crescimento; tornavam-se obstáculos, igualmente, a falta de uma clara divisão de bases tributárias entre o poder central e os governos regionais, bem como a ausência de parâmetros para a repartição da arrecadação e dos gastos tributários ${ }^{222}$.

Os autores defendem que o federalismo poderá ter um papel importante no desenvolvimento da Rússia, mas alertam que isso somente será possível por intermédio de uma centralização política mais forte. Para alcançar esse desiderato, sugerem a atuação sob duas bases: a) escolha, pelo governo central, da extensão da divisão de rendimentos com os governos locais à medida e na proporção em que estes viabilizem o crescimento em suas áreas administrativas; b) centralização política, podendo o governo central interferir no tempo de permanência dos governantes locais para usufruírem dos benefícios do crescimento ou dos privilégios privados advindos com o obstáculo ao crescimento ${ }^{223}$.

Olivier Blanchard e Andrei Shleifer partem do pressuposto de que o poder central está menos propenso à atuação dos caçadores de rendas, principalmente quando a questão diz respeito ao crescimento: o governo local é suscetível aos pleitos de transferências de rendas ou proteção, pois sofre as consequências advindas do desemprego ou fechamento de empresas que exigem esses benefícios. Não quer dizer, porém, que o poder central esteja livre da "captura", uma vez que esta pode ocorrer sobre outras bases que não a diminuição

levels of government. It may be argued that engaging in these activities diverts firms' resources from more productive uses, thus impeding growth".

222 Olivier Blanchard e Andrei Shleifer. Fev. 2000. MIT Dept. of Economics Working Paper n. 00-15; Harvard Institute of Economics Research Paper n. 1889. Disponível em http://ssrn.com/abstract=236127; acessado em 16.07.2008.

223 Olivier Blanchard e Andrei Shleifer. Fev. 2000. MIT Dept. of Economics Working Paper n. 00-15; Harvard Institute of Economics Research Paper n. 1889. Disponível em http://ssrn.com/abstract=236127; acessado em 16.07.2008. 
do crescimento, como, por exemplo, em face do aumento da riqueza para determinados $\operatorname{grupos}^{224}$.

A análise dos autores é importante porque aborda, sob o ponto de vista econômico, por que existe tanta diferença em relação ao crescimento e ao desvio de recursos em dois países que adotam o federalismo. Além disso, traz uma discussão importante sobre os eventuais benefícios de uma centralização política como forma de incentivar práticas de boa governança na atuação dos governos locais e regionais.

Um estudo igualmente relevante é o desenvolvido por Sebastian Freille, M. Emranul Haque e Richard Kneller ${ }^{225}$, os quais concluíram que, sem corrupção, a descentralização é inegavelmente a melhor alternativa para o desenvolvimento. Se, porém, a corrupção se mostra intensa, a descentralização pode estar relacionada à menor obtenção de capital, principalmente quando, no nível local, houver a existência de instituições instáveis. Nessa hipótese, a melhor opção seria a centralização, caso o poder central seja capaz de efetuar um controle mais eficiente da corrupção.

Depreende-se que a relação existente entre centralização, descentralização e o desvio de recursos públicos é a preocupação constante desses estudos. As pesquisas, embora reconheçam a existência dessa relação, não apresentam soluções uniformes para o tratamento do problema: ora adotam como saída uma centralização maior, ora uma descentralização mais abrangente como forma de evitar a corrupção ou outras práticas que provoquem o desencaminhamento de recursos.

As discrepâncias presentes nos mencionados estudos são fruto, justamente, da inexistência de um modelo único de federação. De fato, conforme já apontado no primeiro capítulo (item 1.3.1) do presente trabalho, o arquétipo do federalismo não é uniforme.

Além disso, há que se recordar que a conjugação das funções fiscais, com fins ao equilíbrio da federação, não é uma prática facilmente realizada ${ }^{226}$, motivo pelo qual muitos países, na estruturação dessas funções, não adotam esquemas semelhantes. Pode-se afirmar, inclusive, que as federações existentes não adotam precisamente todos os

224 Olivier Blanchard e Andrei Shleifer. Fev. 2000. MIT Dept. of Economics Working Paper n. 00-15; Harvard Institute of Economics Research Paper n. 1889. Disponível em http://ssrn.com/abstract=236127, acessado em 16.07.2008.

225 Decentralisation, Corruption and Economic Development. (16 mar 2007). Disponível em http://ssrn.com/abstract=985638, acessado em: 16.07.2008.

226 Vide item 2.1 do presente estudo. 
princípios descritos na teoria do federalismo fiscal, ocorrendo na prática uma situação bem diferente do exposto na doutrina. Nesse sentido, Jonathan Rodden ${ }^{227}$ observa que:

A literatura normativa sobre o federalismo fiscal, assim como as teorias constitucionais norte-americanas sobre o federalismo dual, têm tido efeitos obscurecedores. Muito freqüentemente, economistas e cientistas políticos teorizam sobre descentralização como se ela significasse uma divisão nítida de tarefas, em que o centro só entra para a provisão de bens coletivos nacionais e para corrigir desvios. As noções de federalismo que prevalecem na Ciência Política criam um problema parecido. O federalismo não necessariamente acarreta uma autoridade maior dos governos subnacionais sobre os impostos, gastos ou qualquer outra coisa. $\mathrm{O}$ federalismo não implica que o centro e os estados sejam soberanos, cada um protegido contra a interferência do outro. Ao contrário, as federações têm evoluído para contratos incompletos em andamento e pela sua própria natureza estão sob constante renegociação. Na maior parte das federações, o centro depende das províncias para implementar e fazer valer muitas das suas decisões e não pode efetuar mudanças do status quo em algumas áreas sem o consentimento das unidades constituintes.

Fácil conceber, então, que existem Estados ditos federados que apresentam aspectos diferentes de outros da mesma categoria. Vale dizer, alguns desses Estados podem adotar uma característica mais ou menos centralizadora do que outros, principalmente no tocante à repartição de receitas e à autonomia dos entes subnacionais ${ }^{228}$.

É por esse motivo que não se pode afirmar que os Estados unitários são tão ou mais corruptos do que os Estados descentralizados, até mesmo porque existem federações que apresentam um grau de descentralização fiscal muito baixo (Croácia, Malásia e Indonésia,

227 Federalismo e descentralização em perspectiva comparada: sobre significados e medidas. Tradução de Miriam Adelman e Marta Arretche. In: Revista de Sociologia e Política, jun. 2005, n. 24, Curitiba, p. 20. Também disponível em http://www.scielo.br/scielo.php?pid=S010444782005000100003\&script=sci_arttext\&tlng=, acessado em 17.07.2008.

228 Nesse sentido, aliás, é a observação de Sebastian Freille, M. Emranul Haque e Richard Kneller (Decentralisation, Corruption and Economic Development. (16 mar 2007). Disponível em http://ssrn.com/abstract=985638, acessado em 16.07.2008): "Além disso, há uma confusão de evidências a respeito da relação entre descentralização e corrupção na literatura empírica. Enquanto há alguns estudos que julgaram que o federalismo é associado à maior corrupção na economia, outros autores têm constatado que a descentralização físcal é associada a uma corrupção menor. Novamente, os últimos desenvolvimentos empíricos sugerem que é talvez mais conveniente adotar uma abordagem mais integral para o estudo da descentralização e corrupção, considerando as inter-relações entre diferentes aspectos ou tipos de descentralização. As idéias apresentadas neste capítulo se harmonizam com isso se considerarmos que o progresso da eficiência econômica é associado a certos modelos de descentralização e reduzido controle hierárquico, bem como problemas de informação e inspeção são associados a outros tipos de descentralização". (tradução livre do autor). No original: "Furthermore, there is mixed evidence regarding the relationship between decentralisation and corruption in the empirical literature. While there are some studies that find that federalism is associated to more corruption in the economy, other authors have found that fiscal decentralisation is associated to lower corruption. Again, the latest empirical developments suggest that it is perhaps more convenient to adopt a more integrated approach to the study of decentralisation and corruption considering the interrelationships between different aspects or types of decentralisation. The ideas presented in this chapter accord with this if we consider that improved economic efficiency is associated to certain type of decentralisation and reduced hierarchical control and informational and monitoring problems are associated to other types of decentralisation". 
por exemplo) e Estados unitários cujo nível de descentralização fiscal é bastante significativo (como são exemplos os países nórdicos) ${ }^{229}$. Isso comprova que, apesar de um determinado país adotar o modelo federalista, não significa que seu nível de descentralização seja elevado; o mesmo entendimento é válido para o Estado unitário.

A conclusão acima também leva a outra, ou seja, deve-se partir do pressuposto de que a descentralização, aí incluída a forma federalista, apresenta diferentes perspectivas - a política, a fiscal etc. -, devendo ser avaliada, notadamente, a atuação de cada uma delas no incentivo ao desvio de recursos públicos. Poder-se-á, dessa forma, investigar se determinado Estado federal apresenta ou não uma estrutura favorável à prática da corrupção.

As mencionadas perspectivas são denominadas por Sebastian Freille, M. Emranul Haque e Richard Kneller como "dimensões da descentralização", reconhecendo os autores que cada uma delas apresenta efeitos importantes. Consideram, assim, que a atuação das descentralizações política, fiscal, constitucional (assim entendida aquela que consta, explicitamente, na Constituição dos Estados) e estrutural (número de níveis governamentais e número de jurisdições pertencentes a cada um desses níveis), bem como a relação existente entre elas têm influência direta para o incentivo ou inibição de práticas de desvio de recursos ${ }^{230}$.

Jonathan Rodden ${ }^{231}$ afirma, também, que existem outras variáveis importantes algumas desconsideradas por pesquisas empíricas - que devem ser apreciadas para analisar o nível de descentralização dos Estados. Os efeitos da distribuição de autoridades políticas (descentralização política) representam uma dessas variáveis, além das descentralizações fiscal e de políticas.

229 Sebastian Freille, M. Emranul Haque e Richard Kneller. Federalism, decentralisation and corruption. (junho 2007). Disponível em http://ssrn.com/abstract=951110, acessado em 16.07.2008. No original: "Under some conditions centralized governments are more corrupt whereas under some other definition of decentralisation they are more corrupt. [...]

However, there are cases of unitary countries with a high degree of fiscal decentralisation, as the Nordic countries. At the same time, there a some federal countries with very low levels of fiscal decentralisation, as is the case of Croatia, Malaysia and Indonesia".

230 Federalism, decentralisation and corruption. (junho 2007). Disponível em http://ssrn.com/abstract=951110, acessado em 16.07.2008, passim.

231 Federalismo e descentralização em perspectiva comparada: sobre significados e medidas. Tradução de Miriam Adelman e Marta Arretche. In: Revista de Sociologia e Política, jun. 2005, n. 24, Curitiba, pp. 927. Também disponível em http://www.scielo.br/scielo.php?pid=S0104$44782005000100003 \&$ script=sci_arttext\&tlng=, acessado em 17.07.2008. 
No tocante à descentralização fiscal, considera que devem ser observados, ainda, três pontos importantes:

a) não é suficiente avaliar, simplesmente, a distribuição de despesas e receitas entre os governos locais e regionais, ou seja, a descentralização do gasto governamental; tornase necessário, igualmente, verificar o nível de autoridade para o exercício desses gastos, a fim de perscrutar se o governo central mantém ou não um controle rígido ou alguma intervenção sobre as decisões dos governos locais e regionais no momento das despesas;

b) na avaliação das fontes de financiamento do gasto, deve haver a diferenciação entre transferências intergovernamentais, receitas próprias, empréstimos e transferências constitucionalmente compartilhadas. Ainda sobre esse aspecto, a fim de não se cometer equívocos quanto ao grau de autonomia dos entes subnacionais em relação à arrecadação de suas próprias receitas, deve-se verificar se o governo central interfere de alguma forma nessa autonomia, ao estabelecer, por exemplo, alíquotas e bases tributárias;

c) a autonomia fiscal dos entes subnacionais não deve ser avaliada apenas no tocante à intervenção do poder central nas transferências condicionadas e na regulação da arrecadação local de impostos, mas também em relação às restrições impostas pelo mesmo governo central para a aquisição de empréstimos pelos governos locais e regionais ${ }^{232}$.

A descentralização de políticas também é uma questão a ser analisada, uma vez que existem países nos quais os governos locais não possuem autonomia plena para o investimento em educação, infraestrutura ou polícia, por exemplo, compartilhando essa autoridade com os governos regionais ou com o poder central ${ }^{233}$.

Diante do aqui exposto, embora se reconheça que as pesquisas já mencionadas possuem pouca utilidade para definir qual a melhor forma de estruturação do Estado (a centralização ou a descentralização), são justamente esses mesmos estudos que servirão de

232 Jonathan Rodden. Federalismo e descentralização em perspectiva comparada: sobre significados e medidas. Tradução de Miriam Adelman e Marta Arretche. In: Revista de Sociologia e Política, jun. 2005, n. 24, Curitiba, pp. 10-15. Também disponível em http://www.scielo.br/scielo.php?pid=S010444782005000100003\&script=sci_arttext\&tlng=, acessado em 17.07.2008. A maioria dessas recomendações de Jonathan Rodden em relação à descentralização fiscal representa, também, uma crítica à publicação do FMI Government Finance Statistics Yearbook e às pesquisas empíricas que dela se utilizam. A publicação do FMI apresenta apenas a distribuição de gastos e receitas entre os entes governamentais, o que, segundo o autor, não é suficiente para detectar o grau de descentralização fiscal de um país.

233 Jonathan Rodden. Federalismo e descentralização em perspectiva comparada: sobre significados e medidas. Tradução de Miriam Adelman e Marta Arretche. In: Revista de Sociologia e Política, jun. 2005, n. 24, Curitiba, pp. 15-16. Também disponível em http://www.scielo.br/scielo.php?pid=S010444782005000100003\&script=sci_arttext\&tlng=, acessado em 17.07.2008. 
fundamental subsídio para ponderar a relação existente entre cada uma das dimensões da descentralização e o incentivo ao desvio de recursos públicos.

Como o federalismo envolve todas essas dimensões, serão justamente eles que auxiliarão na análise do caso brasileiro, a fim de se investigar se o federalismo fiscal pátrio apresenta ou não uma estrutura que provoca o surgimento de estímulos à corrupção ou a outras formas de desvio de recursos. 
Capítulo 3

\section{O ARCABOUÇO DO FEDERALISMO FISCAL BRASILEIRO E OS INCENTIVOS AO DESVIO DE RECURSOS PÚBLICOS}

3.1 A federação brasileira e a concentração de poder no governo central - 3.2 A repartição de competências, o nível de descentralização fiscal e de políticas previstas na Constituição Federal, o problema da rigidez orçamentária e a frágil autonomia dos entes subnacionais - $3.3 \mathrm{O}$ controle do endividamento dos entes subnacionais e ainda a questão da autonomia - 3.4 A assimetria da federação brasileira e a descentralização política - 3.5 A competição vertical no federalismo fiscal brasileiro e a autoridade compartilhada na elaboração de políticas - 3.6 A competição horizontal no federalismo fiscal brasileiro: 3.6.1 A dificuldade em estabelecer a competição horizontal entre os municípios brasileiros; 3.6.2 A competição horizontal entre os estados e a questão da guerra fiscal 3.7 A necessidade de se repensar a federação e o federalismo fiscal brasileiros: 3.7.1 A ausência de equilíbrio nas dimensões da descentralização brasileira; 3.7.2 O importante papel das instituições no federalismo fiscal brasileiro e a questão da accountability e do controle.

\subsection{A federação brasileira e a concentração de poder no governo central}

A federação brasileira originou-se por meio de segregação, uma vez que, por meio de decreto, as províncias transformaram-se em estados, os quais passaram a compor a federação.

Da observação dessa gênese do federalismo pátrio é que se pode explicar, desde logo, a tendência da concentração de um poder maior em mãos da União. De fato, embora o mencionado decreto tenha provocado a mudança formal de um Estado unitário descentralizado (Império) para um Estado federal, tal transformação não foi suficiente para retirar o papel altamente centralizador da União, situação que persiste atualmente em níveis consideráveis.

Não por acaso, Alfred Stepan estabelece a diferença entre federações que tinham como objetivo primeiro o de "unir", como são exemplos os Estados Unidos, e aquelas que possuíam como propósito inicial "manter a união", das quais Índia (1948), Bélgica (1969) e Espanha (1975) são modelos. Segundo o autor, nas federações cujo objetivo era a união, "um aspecto decisivo do pacto federativo para a soberania dos estados que concordaram em se unir foi o fato de que a construção da nova federação incluiu certas características verticais e 
horizontais que restringiram o conjunto dos cidadãos da polis na esfera central”. Já as federações formadas com o objetivo de "manter a união" apresentavam, inicialmente, marcante caráter unitário (casos da Índia, Bélgica e Espanha), motivo pelo qual "nessas três sociedades multiculturais os líderes políticos chegaram à decisão constitucional de que a melhor maneira de 'manter a união' em uma democracia era transferir poder e transformar seus Estados unitários ameaçados em federações"234.

No caso do Brasil, a federação formou-se com o objetivo de manter a união. De fato, já a partir de 1834, com a aprovação de emenda constitucional, denominada à época de Ato Adicional, consagrou-se maior autonomia às províncias, embora o objeto formal do projeto de emenda constitucional pretendesse estabelecer uma "monarquia federativa",235. O motivo da emenda era assegurar a "manutenção da unidade de todo o território da América lusitana sob um único Estado"236.

A herança do Império, porém, consistente no franco domínio do poder central, permaneceu após a proclamação da República. O surgimento da Federação não alterou de

234 Para uma nova análise comparativa do federalismo e da democracia: federações que restringem ou ampliam o poder do Demos. In: Dados - Revista de Ciências Sociais. Rio de Janeiro, v. 42, n. 2, 1999, pp. 593-634. Tradução de Vera Pereira. Título original: Toward a New Comparative Analysis of Democracy and Federalism: Demos Constraining and Demos Enabling Federations. Disponível em http://www.scielo.br/scielo.php?script=sci_arttext\&pid=S0011-52581999000200001\&lng=pt\&nrm=iso, acessado em 26.11.2009.

235 Importante ressaltar, nesse ponto, que embora as províncias não possuíssem autonomia plena, tiveram papel fundamental para a formação do federalismo brasileiro. Esclarece Miriam Dolhnikoff ( $O$ pacto imperial: origens do federalismo no Brasil do século XIX. São Paulo: Globo, 2005, p. 97) que a partir de 1834, com a aprovação da emenda constitucional (Ato Adicional), foram dados maiores níveis de autonomia às províncias. A autora expõe os avanços e limites dessa autonomia: “A divisão constitucional de competências entre governos provinciais e governo central, garantindo autonomia dos primeiros, a qual não podia ser unilateralmente revogada pelo governo central; a capacidade de os governos provinciais tomarem decisões autonomamente sobre temas relativos à tributação, força policial, obras públicas, empregos, etc.; a constante negociação entre províncias e centro no parlamento para dirimir tensões e confrontos entre interpretações divergentes sobre a esfera de competência de cada um; a atribuição do governo central de responder pela unidade nacional, provido dos instrumentos necessários para tanto; e sua convivência com governos provinciais autônomos, que respondiam por questões regionais estratégicas, foram elementos federativos que marcaram a organização institucional que prevaleceu no Brasil do século XIX. A derrota na negociação das reformas em 1832, que resultou na manutenção da vitaliciedade do Senado, e o fato de ser o presidente de província nomeado pelo governo central impediram a adoção plena de um modelo federativo. Por outro lado, como procurei demonstrar, o presidente tinha poderes restritos, de sorte que ele não se constituía em obstáculo ao exercício da autonomia provincial. O presidente não tinha poder de apresentar projetos legislativos, e o direito de veto às leis aprovadas na Assembléia era apenas suspensivo. Deveria ser exercido em um prazo diminuto, apenas dez dias, e retornava para a mesma Assembléia que aprovara a lei, na qual poderia ser derrubado por dois terços dos deputados. De qualquer forma, se a organização institucional do Brasil no século XIX não preenche todos os requisitos do modelo federal, o que importa é que alguns elementos essenciais estavam presentes e foram condição para a unidade do país, na medida em que foram a maneira encontrada para incorporar ao novo Estado elites provinciais que passaram a ter poder decisivo na condução deste Estado e que, caso contrário, poderiam optar pela separação". (Op. cit., pp. 291-292).

236 DOLHNIKOFF, Miriam. O pacto imperial: origens do federalismo no Brasil do século XIX. São Paulo: Globo, 2005, p. 292. 
forma considerável esse panorama, de forma que a autonomia dos Estados-membros sempre se apresentou relativa, inclusive com o advento de Constituições posteriores ${ }^{237}$.

Em relação à atual Carta Magna, atente-se que o caput de seu artigo 18 estabelece que "a organização político-administrativa da República Federativa do Brasil compreende a União, os Estados, o Distrito Federal e os Municípios, todos autônomos”, mas acrescenta, em seguida, a expressão "nos termos desta Constituição", deixando claro que a autonomia dos governos locais e regionais é restrita.

A ausência de autonomia plena dos entes subnacionais é capaz de gerar dúvidas a respeito da real existência de um modelo federativo no Brasil. Esse receio, no entanto, é afugentado pelas afirmações já expostas nos capítulos anteriores do presente estudo, em que se constatou que, na verdade, não há um padrão de federação, mas sim especificidades inerentes a cada Estado federal.

Lembra-se que o modelo federativo pressupõe um "contrato" entre as unidades que o compõem, de forma que tal pacto variará em razão do povo pertencente a esse Estado, da sua

237 Esse também é o entendimento de Marcelo Figueiredo (Federalismo x Centralização. A eterna busca do equilíbrio - A tendência mundial de concentração de poderes na União. A questão dos governos locais. In: Interesse Público. Porto Alegre: Notadez, ano 9, no 41, jan-fev de 2007, p. 100):

"A República nasce no Brasil sob a inspiração liberal e acolhe a idéia de descentralização do poder. Entretanto, ao longo dos anos seguintes, não se vê uma verdadeira federação equilibrada.

De fato, a história constitucional do Brasil revela ora uma União (poder central) privilegiada ora despida de poderes de que necessita para governar o interesse nacional".

Igual entendimento apresentou o Ministro Paulo Brossard em seu voto na Medida Cautelar em Ação Direta de Inconstitucionalidade $\mathrm{n}^{\circ} 216$ (Paraíba), relator Min. Célio Borja, requerente: Governador do Estado da Paraíba, requerida: Assembleia Legislativa do Estado da Paraíba, julgado em 23.05.90, por maioria (Tribunal Pleno), e publicado no D.J. de 07.05.93. Na ocasião, o Ministro afirmou:

"No Brasil, a verdade é que o período de 30 a 34 foi um período unitário; o período que vem de 37 a 46 é um período unitário; o período que começa em 65 e vai a 67 foi um período fortemente unitário; no período que se inicia em 69 e durou não sei quantos anos, malfadados anos, também a federação foi reduzida a uma ficção.

A observação que se tem feito notar é que embora se clame muito por federação pouco se pratica a federação, quando se tem efetivamente a competência para usá-la”.

Na ementa do mesmo julgado ficou clara, também, a opinião do Supremo Tribunal Federal a respeito da atual Constituição de 1988 no tocante à forte centralização de poder na União:

"O perfil da Federação brasileira, redefinido pela Constituição de 1988, embora aclamado por atribuir maior grau de autonomia aos Estados-membros, é visto com reserva por alguns doutrinadores, que consideram persistir no Brasil um federalismo ainda afetado por excessiva centralização espacial do poder em torno da União Federal.

Se é certo que a nova Carta Política contempla um elenco menos abrangente de princípios constitucionais sensíveis, a denotar, com isso, a expansão de poderes jurídicos na esfera das coletividades autônomas locais, o mesmo não se pode afirmar quanto aos princípios federais extensíveis e aos princípios constitucionais estabelecidos, os quais, embora disseminados pelo texto constitucional, posto que não é tópica a sua localização, configuram acervo expressivo de limitações dessa autonomia local, cuja identificação - até mesmo pelos efeitos restritivos que deles decorrem - impõe-se realizar". 
cultura, das especificidades geográficas etc. A respeito disso, Themistocles Brandão Cavalcanti ${ }^{238}$ já alertava:

A tarefa não é fácil [caracterizar o sistema federal] porque a diferenciação dos diversos tipos é tão grande que se torna quase impossível fixar os seus traços essenciais, ou mesmo o mínimo de condições necessárias à integração do Estado federado. Cada Estado novo que surge traz novas variantes, baixando sempre mais os pontos de diferenciação com o Estado unitário.

[...]

Essa diferenciação tão grande de teorias explica-se, no entretanto, de uma maneira muito simples: a formação da estrutura política de um Estado não pode ser obra de decalque; não se constrói com o espírito preconcebido, sôbre um tipo a priori imaginado, uma constituição política. Esta decorre das condições peculiares a cada povo.

Deve-se reconhecer, diante dessas constatações, que no Brasil persiste o arquétipo federativo, ainda que se considere a grande absorção de poder na esfera central de governo $(\text { União })^{239}$, como a seguir se observará.

\subsection{A repartição de competências, o nível de descentralização fiscal e de políticas previstas na Constituição Federal, o problema da rigidez orçamentária e a frágil autonomia dos entes subnacionais}

No tocante à repartição de competências, o Estado brasileiro adota uma estrutura mista, em que coexistem dois modelos: o cooperativo (repartição vertical), o qual permite

238 Teoria do Estado. Rio de Janeiro: Editor Borsoi, 1958, pp. 201-202.

239 O Ministro Paulo Brossard, em voto na MC-ADIN n 216-PB, do Supremo Tribunal Federal, reconhece as particularidades de cada federação, inclusive a do Brasil, ao afirmar:

"Nos anos de 33 e 34 o chamado projeto do Itamarati, enviado pelo Governo à Assembléia Constituinte em 1933, recebeu muitas críticas dada a suposta quebra dos padrões federalistas. O argumento vinha mais ou menos formulado nesses termos: tudo era incompatível com a federação, o que levou JOÃO MANGABEIRA a dizer que não havia um padrão federativo, um padrão mundial de federação; havia federações, a federação americana era diferente da federação canadense; a federação brasileira era diferente da federação argentina; a federação alemã era diferente da federação austríaca e assim por diante. E usou mesmo dessa comparação; a federação não era uma espécie de metro do irídio que estivesse guardado no observatório de Paris correspondente à décima milionésima parte do quarto do meridiano terrestre. Textualmente:

‘...o regime federativo não se vasa num molde permanente. ... a Constituição Americana não é o metro do irídio conservado em Paris, como padrão da décima milionésima parte do quarto do meridiano terrestre. A federação é uma forma de Estado; um sistema de composição de forças, interesses e objetivos, variável no tempo e no espaço, e inerente e peculiar a cada povo. Plasma-se, por isso mesmo, de acordo com as necessidades e os sentimentos de cada Nação. O regime federativo dos Estados Unidos não é o do Canadá; nem este o da Austrália. O do Brasil não é nenhum desses, nem o Argentino, nem o Mexicano. O da Alemanha não é o da Áustria, nem o da Suíça ou o da Rússia.' (João Mangabeira, em Tomo da Constituição, 1934, p. 21).

Tenho um pouco de receio, Senhor Presidente, quando vejo uma questão proposta nesses termos [nesse ponto, o Ministro se refere ao caso concreto, objeto da MC-ADIN no 216-PB], porque não existe um padrão único de federação, um modelo invariável acima do tempo e do espaço, mas existem experiências federativas". 
que determinadas atividades sejam realizadas de forma concorrente pelos estados federados; e o dual (repartição horizontal), que estabelece a competência própria de cada ente da federação, impendido a interferência de um na competência de outro ${ }^{240}$.

A estrutura dessa repartição, no entanto, é bastante complexa, como se pode observar a respeito da competência legislativa, na qual tanto a repartição vertical quanto a horizontal estão presentes. A título de exemplo, menciona-se que a Constituição Federal explicita as competências exclusivas da União, dos Estados, do Distrito Federal e dos Municípios para legislarem sobre algumas matérias e, ao mesmo tempo, disciplina as matérias que serão objeto de competência concorrente entre esses mesmos entes (exceto aos Municípios que, nesse aspecto, possuem apenas a competência complementar) ${ }^{241}$.

No que se refere à competência para a instituição de tributos, predomina no federalismo brasileiro a repartição horizontal de competências (modelo dualista). Dessa forma, cabe à União instituir impostos sobre: importação; exportação; renda e proventos de

240 Confira-se, a propósito, o entendimento de José Mauricio Conti (Federalismo fiscal e fundos de participação. São Paulo: Editora Juarez de Oliveira, 2001, p. 24):

"Cumpre destacar que o federalismo brasileiro, relativamente ao modo pelo qual está organizado, tem algumas características de um federalismo dualista, na medida em que estabelece campos específicos de atuação para cada uma das entidades, delimitando a área de atuação da União, dos Estados-membros e dos Municípios.

Por outro lado, também adota técnicas de um federalismo cooperativo, ao estabelecer campos de atuação concorrentes.

Portanto, vê-se que o modelo brasileiro adota um sistema misto, incorporando tanto técnicas próprias do federalismo dualista quanto técnicas do federalismo cooperativo. É de se considerar predominante, no entanto, o aspecto cooperativo, que se vem observando de modo cada vez mais significativo nos Estados modernos, sendo esta uma tendência do federalismo atual".

Em relação à repartição de competência legislativa, Manoel Gonçalves Ferreira Filho (Curso de direito constitucional. $29^{a}$ ed., rev. e atual. São Paulo: Saraiva, 2002, pp. 59-60) é didático ao esclarecer:

"Quanto a esta [repartição de competência legislativa], no texto em vigor, há, por um lado, uma repartição estabelecida segundo o critério 'horizontal'.

Assim, há competências exclusivas da União (p. ex., art. 22), dos Municípios (art. 30) e dos Estados e do Distrito Federal. A competência exclusiva dos Estados compreende tudo aquilo que não foi atribuído à União ou aos Municípios (ou não foi incluído no campo das competências concorrentes) (art. 25, $1^{\circ}$ ). A competência exclusiva do Distrito Federal abrange o que não foi atribuído à União (ou não foi incluído no campo das competências concorrentes), mas também o que foi conferido ao Município (art. $32, \S 1^{\circ}$ ). A competência exclusiva do Município abrange o que for assunto de 'interesse local' (art. 30, I).

Por outro lado, existe uma repartição vertical. Há uma competência concorrente deferida à União, aos Estados e ao Distrito Federal (não aos Municípios) (art. 24). Neste campo, compete à União estabelecer apenas as 'normas gerais' (art. 24, $\S 1^{\circ}$ ). Aos Estados e ao Distrito Federal cabe complementar essas normas, adaptando-as às suas peculiaridades (competência complementar, que a Constituição incorretamente chama de 'suplementar', art. $24, \S 2^{\circ}$ ).

$\mathrm{Na}$ falta de normas gerais editadas pela União, os Estados e o Distrito Federal podem editá-las, suprindo a lacuna (competência supletiva, que a Constituição também chama de 'suplementar', de modo incorreto, art. $24, \S 3^{\circ}$ ). Neste caso, porém, editando a União as normas gerais, estas prevalecerão sobre as que houverem sido promulgadas pelos Estados ou pelo Distrito Federal (art. $24, \S 4^{\circ}$ ).

A Constituição não atribui aos Municípios competência legislativa concorrente com a da União, Estados e Distrito Federal. Entretanto, confere a eles uma competência de 'suplementar' (entenda-se, 'complementar') a legislação federal e estadual, no que for de seu interesse peculiar (art. 30, II)". 
qualquer natureza; produtos industrializados; operações de crédito, câmbio e seguro, ou relativas a títulos ou valores mobiliários; propriedade territorial rural; grandes fortunas, possibilidade ainda não configurada devido à inexistência de lei complementar regulamentando a matéria (artigo 153, da Constituição Federal). Também é de sua competência exclusiva instituir empréstimos compulsórios (artigo 148, da Constituição Federal), contribuições sociais, de intervenção no domínio econômico e de interesse das categorias profissionais ou econômicas (artigo 149, da Constituição Federal), bem como impostos extraordinários (artigo 154, inciso II, da Constituição Federal). A competência residual também é atribuição sua no que se refere à criação de outros impostos, desde que não sejam cumulativos e não tenham fato gerador ou base de cálculo próprios dos previstos na Constituição Federal (artigo 154, inciso I, da Constituição Federal).

Os Estados e o Distrito Federal podem instituir impostos sobre: transmissão causa mortis e doação; operações relativas à circulação de mercadorias e sobre prestação de serviços de transporte interestadual e intermunicipal e de comunicação, ainda que as operações e as prestações se iniciem no exterior; propriedade de veículos automotores (artigo 155, da Constituição Federal).

Aos Municípios compete a instituição de impostos sobre: propriedade predial e territorial urbana; serviços de qualquer natureza (exceto os definidos no art. 155, inciso II, da $\mathrm{CF}$ ); transmissão de bens imóveis inter vivos (art. 156, da CF).

Deve ser objeto de realce o fato de que, embora no campo da instituição de tributos prevaleça a técnica da repartição horizontal de competências, o mesmo modelo não predomina na hipótese da repartição do produto da arrecadação desses tributos, uma vez que o valor recolhido dos contribuintes pode não permanecer integralmente em poder do ente federado que realizou referida arrecadação ou instituiu o tributo.

De fato, a Constituição Federal especifica, em seus artigos 157 a 159, os percentuais que serão destinados para os Estados, Distrito Federal e Municípios. A mencionada repartição representa: a) uma parcela da arrecadação de impostos instituídos pela União, direcionados aos Estados, Distrito Federal e Municípios; b) uma porcentagem da arrecadação de impostos instituídos pelos Estados, dirigidos aos respectivos Municípios. O encaminhamento de recursos da União para o Fundo de Participação dos Estados e do Distrito Federal, para o Fundo de Participação dos Municípios e para os programas de 
financiamento ao setor produtivo das Regiões Norte, Nordeste e Centro-Oeste possui previsão no artigo 159, inciso I, alíneas "a" a "c" da Constituição Federal.

A técnica dessa repartição de receita prevista na Carta Magna é assim caracterizada por José Afonso da Silva ${ }^{242}$ :

Essa técnica é conhecida como federalismo cooperativo $^{243}$. Predomina o critério da repartição em favor da entidade participante, mas é possível distinguir três modalidades de participação: (a) a participação em impostos de decretação de uma entidade e percepção por outras - caso em que os recursos, arrecadados pela própria entidade beneficiada, integram, desde logo, seu patrimônio (arts. 157, I, e 158, I); (b) a participação em impostos de receita partilhada segundo a capacidade da entidade beneficiada - caso em que a participação se realiza por meio de uma percentagem no produto da arrecadação, coletada pela entidade titular do poder tributante, e devolvido o quantum respectivo às entidades beneficiadas, porque a elas pertence de direito, e pode ser exigido até judicialmente; (c) participação em fundos - caso em que a entidade beneficiada tem uma expectativa de receber certa quantia do fundo, conforme critério de redistribuição geográfica de rendas que tais fundos visam a realizar.

Depreende-se que a federação brasileira, que se formou por meio da segregação, organiza-se, predominantemente, sob a forma cooperativa.

Se é correto afirmar que hoje a Federação brasileira apresenta uma concentração maior de poder em mãos do governo central, não menos verdade é a afirmação de que antes do advento da Constituição Federal de 1988 esse poder era ainda maior.

De fato, a atual Carta Magna pretendeu ampliar o nível de descentralização por intermédio da concessão de receitas próprias para os demais entes federados, do estabelecimento de novos parâmetros para a repartição de receitas, da criação de novas regras para as transferências intergovernamentais e da ampliação dos fundos de participação.

Em relação às receitas próprias, por exemplo, os Estados incrementaram sua base de tributação mediante a possibilidade de instituírem o ICMS (imposto sobre operações relativas à circulação de mercadorias e sobre prestações de serviços de transporte interestadual e intermunicipal e de comunicação), formado por impostos que eram, anteriormente, de competência da União ${ }^{244}$.

242 Comentário contextual à Constituição. São Paulo: Malheiros, 2005, p. 677.

243 Da mesma forma, Fernando Facury Scaff (Como a sociedade financia o Estado para a implementação dos direitos humanos no Brasil. In: Interesse Público. Porto Alegre: Notadez, ano 8, $\mathrm{n}^{\mathbf{o}}$ 39, set-out de 2006, p. 196) ressalta que, "em razão de um mecanismo denominado de federalismo participativo, também chamado de federalismo cooperativo, parte do que é arrecadado é partilhado com outros entes federados".

244 Sobre esse fato, Maria Nazaré Lins Barbosa e Virgínia Talaveira Valentini Tristão (Federalismo, Clientelismo e Reforma Fiscal. In: Caderno de Pesquisas em Administração, São Paulo, v. 1, n. 8, $1^{\circ}$ 
Os Municípios, por sua vez, passaram a instituir o ITBI (imposto sobre transmissão de bens imóveis por ato inter vivos), antes de competência dos Estados. Além disso, foi excluída a hipótese de interferência da União nos impostos de competência dos entes subnacionais, uma vez que não mais se permitiu que o governo central aplicasse isenções a tributos de competência dos demais entes ${ }^{245}$.

Inegável, assim, que quanto à descentralização fiscal, a atual Constituição pretendia avanços nesse sentido.

Ocorre que esse fato não veio acompanhado de outras dimensões de descentralização, principalmente quando se denota que a maioria das atribuições (repartição de encargos), antes destinadas à União, permaneceram com ela; foi-lhe retirada parcela de receita, mas não os encargos proporcionais.

Dircêo Torrecillas Ramos também observou esse aspecto ao afirmar que, com a atual Constituição Federal, "houve uma descentralização de receitas, mas não houve a descentralização administrativa"246. O autor $^{247}$ complementa seu entendimento com exemplos:

A União perdeu receita e ganhou mais atribuições, porque os Poderes Legislativo, Executivo e Judiciário cresceram. No Legislativo devido à criação de três novos Estados o que aumentará o número de representantes na Câmara Federal de acordo com cálculo a ser feito, considerando-se número mínimo de oito, a proporcionalidade, e que São Paulo passou de 60 para 70 Deputados; no Senado certamente teremos mais três representantes para cada nova unidade. No Poder Executivo, a Previdência Social tornou-se maior, naturalmente; embora na prática tenha ocorrido, até o momento, ao contrário, a Constituição abriu um caminho para maior estatização e atuação no domínio econômico (arts. 173 e 174). Quanto ao Poder Judiciário, foi-lhe concedida a autonomia financeira e a possibilidade de criação de novos Tribunais e o Superior Tribunal de Justiça, criado pela Constituição, é maior, embora extinto o Tribunal Federal de Recursos.

trimestre de 1999, pp. 64-65. Também disponível em www.ead.fea.usp.br/cad-pesq/arquivos/c8Art6.pdf, acessado em 17.07.2008) relatam: "Os Estados ampliaram sua capacidade de geração de recursos próprios com o aumento considerável da base de tributação do ICMS. Este resultou da fusão do antigo ICM com outros cinco impostos, antes de competência da União: ISTR (transporte), ISC (comunicações); IUCL (combustíveis e lubrificantes); IUEE (energia elétrica) e IUM (minerais).

Além disso, o ICMS passou a admitir seletividade em função da essencialidade do bem, sem estar submetido à restrição antes existente para o ICM de um limite superior determinado pelo Senado. Porém, atribuiu-se ao Senado o poder de estabelecer as alíquotas aplicáveis às operações interestaduais e de exportação. No caso das operações internas, tanto as alíquotas mínimas como as máximas. Ou seja: só a partir deste piso mínimo, podem os Estados manejar alíquotas para cima”.

Maria Nazaré Lins Barbosa e Virgínia Talaveira Valentini Tristão (Federalismo, Clientelismo e Reforma Fiscal. In: Caderno de Pesquisas em Administração, São Paulo, v. 1, n. 8, $1^{\circ}$ trimestre de 1999, pp. 6465. Também disponível em www.ead.fea.usp.br/cad-pesq/arquivos/c8-Art6.pdf, acessado em 17.07.2008).

246 O federalismo assimétrico. São Paulo: Plêiade, 1998, p. 312.

247 O federalismo assimétrico. São Paulo: Plêiade, 1998, pp. 312-313. 
Gilberto Bercovici também analisa a questão e conclui que "o grande problema da repartição de rendas realizada pela Constituição de 1988 foi ter sido realizada a descentralização de receitas e competências sem nenhum plano ou programa de atuação definido entre União e entes federados"248.

Acresça-se a isso o fato de que a União, com o advento da atual Constituição Federal, passou a ter despesas constitucionais obrigatórias, como são exemplos as vinculadas à saúde (art. 198, $\S \S 2^{\circ}$ e $3^{\circ}$, da CF c.c. art. 77, do Ato das Disposições Constitucionais Transitórias) e à educação (artigo 212, da CF c.c. art. 60, do Ato das Disposições Constitucionais Transitórias e Lei 11.494, de 20 de junho de 2007), além de despesas legais igualmente vinculadas. Os mencionados gastos não podem ser contingenciados, o que acaba por diminuir a margem da União para fazer frente a outras despesas ${ }^{249}$.

A alta dívida pública brasileira também foi fonte de preocupação, o que obrigou o país a adotar metas de superavit primário, que significa o resultado positivo da diferença entre receitas e despesas públicas, excluídos desse cálculo os juros referentes à dívida pública $^{250}$. O alcance das metas de superavit primário proporcionaria bons indicadores econômicos ao Brasil no que se refere à relação entre a dívida pública e as receitas, melhorando a atuação do país no cenário mundial e, dessa forma, atraindo mais investimentos externos ${ }^{251}$.

Devido à importância dessas metas, constou expressamente na Lei de Responsabilidade Fiscal (LRF), instituída pela Lei Complementar $n^{\circ} 101$, de 4 de maio de 2000, a prioridade para seu atingimento, inclusive com a previsão de limitação de despesas (exceto as referentes às obrigações legais e constitucionais) para alcançar tal desiderato ${ }^{252}$.

248 Gilberto Bercovici (Dilemas do Estado Federal Brasileiro. Porto Alegre: Livraria do Advogado Editora, 2004, pp. 67 e 69), por outro lado, contesta a afirmação de que teria ocorrido uma descentralização de receitas, mas não de encargos. Afirma que, na verdade, os entes subnacionais vêm atuando em áreas exploradas anteriormente pela União, tais como na de saúde, educação, habitação e saneamento. O problema, afirma ele, é que há "falta de coordenação e cooperação entre a União e os entes federados, que gerou o caos hoje reinante".

249 Nesse sentido, a Lei de Responsabilidade Fiscal (Lei Complementar $n^{\circ} 101$, de 4 de maio de 2000) prevê expressamente o cumprimento obrigatório dessas despesas: "Art. $9^{\circ}$ (...) $\S 2^{\circ}$ Não serão objeto de limitação as despesas que constituam obrigações constitucionais e legais do ente, inclusive aquelas destinadas ao pagamento do serviço da dívida, e as ressalvadas pela lei de diretrizes orçamentárias".

250 Quando o resultado do cálculo é negativo, ou seja, o volume de despesa supera o de receita, diz-se que há um deficit primário.

251 Importantes informações sobre o superavit primário, bem como sua metodologia de cálculo, podem ser encontradas no acórdão do Plenário do Tribunal de Contas da União (TCU) n 1919/2003, sessão de 10.12.2003, referente ao processo $\mathrm{n}^{\circ}$ 010.683/2003-4, cujo relator foi o Ministro Guilherme Palmeira.

$252 \mathrm{O}$ artigo $9^{\circ}$ da LRF disciplina os procedimentos para o atingimento da meta de superavit primário. Eis os excertos do artigo que merecem destaque: "Art. $9^{\circ} \mathrm{Se}$ verificado, ao final de um bimestre, que a realização da receita poderá não comportar o cumprimento das metas de resultado primário ou nominal 
Restringiam-se, mais uma vez, os gastos da União com outras despesas, tais como a de investimento.

A nova situação - ocasionada pela ausência de equilíbrio na descentralização de políticas (repartição de encargos), pela existência de despesas legal e constitucionalmente vinculadas e pela necessidade de adotar metas de superavit primário - provocou reflexos fiscais, uma vez que obrigou o governo central a obter recursos de outra maneira.

A simples majoração de alíquotas ou base de cálculo dos impostos de competência da União não surtiria o efeito desejado, uma vez que parte do produto da arrecadação seria direcionada aos demais entes subnacionais, devido à regra constitucional que disciplinava a repartição de impostos.

Coube ao poder central, então, lançar mão das contribuições, espécies tributárias em que o produto da arrecadação é direcionado integralmente às finalidades da União, não necessitando ser distribuído aos demais entes federados ${ }^{253}$. Com o permissivo contido no artigo 149, da Constituição Federal, a União passou a se valer das contribuições sociais, de intervenção no domínio econômico e de interesse das categorias profissionais ou econômicas, além das contribuições para a seguridade social, estas previstas no artigo 195, § $1^{\circ}$, da mesma Carta.

A adoção de tal procedimento acabou por ocasionar dificuldades estruturais na federação, uma vez que já no ano de 2002 essas contribuições "representavam 57\% da arrecadação federal, gerando problemas de ineficiência, como 'tributação em cascata', distorção de preços relativos e perda de competitividade das exportações" 254 .

O aumento da carga tributária teve como origem a instituição de contribuições como o PIS (Programa de Integração Social), o Pasep (Programa de Formação do Patrimônio do Servidor Público), o Finsocial/Cofins (Fundo de Investimento Social/Contribuição para o Financiamento da Seguridade Social), a CSLL (Contribuição Social sobre o Lucro

estabelecidas no Anexo de Metas Fiscais, os Poderes e o Ministério Público promoverão, por ato próprio e nos montantes necessários, nos 30 (trinta) dias subseqüentes, limitação de empenho e movimentação financeira, segundo os critérios fixados pela lei de diretrizes orçamentárias. (...) § $2^{\circ}$ Não serão objeto de limitação as despesas que constituam obrigações constitucionais e legais do ente, inclusive aquelas destinadas ao pagamento do serviço da dívida, e as ressalvadas pela lei de diretrizes orçamentárias”.

253 Para uma análise mais aprofundada a respeito da origem, conceito e espécies de contribuições, ver CARVALHO, José Augusto Moreira de. Aspectos gerais e controvertidos das contribuições especiais. Revista Tributária e de Finanças Públicas. São Paulo, ano 13, jan-fev, 2005, n. 60, Academia Brasileira de Direito Tributário (ABDT), Editora Revista dos Tribunais, p. 56-92.

254 MENDES, Marcos. Federalismo fiscal. In: ARVATE, Paulo; BIDERMAN, Ciro (org.). Economia do setor público no Brasil. Rio de Janeiro: Elsevier, 2004, p. 459. 
Líquido) e a CPMF (Contribuição Provisória sobre Movimentação Financeira). Dentre outras consequências, a utilização predominante das contribuições provocou a rigidez do orçamento federal, impossibilitando a aplicação de recursos em outras finalidades, tais como os investimentos em infraestrutura ${ }^{255}$.

A explicação para referido enrijecimento apoia-se na natureza das contribuições, cujo produto da arrecadação é necessariamente vinculado, ou seja, somente deve ser direcionado às despesas referentes à finalidade que originou a instituição do próprio tributo. Nesse sentido, por exemplo, a utilização da arrecadação de uma contribuição para a seguridade social não poderia ter aplicação diversa do fim ao qual se destinava (saúde, assistência social e previdência social), o que impedia a União de utilizar esse valor para outras áreas que lhe incumbia atender (investimentos em infraestrutura, por exemplo, necessários ao desenvolvimento do país).

Uma alternativa para evitar o impacto de tais vinculações e para tornar mais flexível o orçamento foi a criação, em 1994, do "Fundo Social de Emergência" (FSE), com o objetivo de sanear financeiramente a Fazenda Pública Federal e possibilitar a estabilização econômica, com a utilização do produto da arrecadação de determinados impostos e contribuições da União para o custeio de ações dos sistemas de saúde e educação, benefícios previdenciários e auxílios assistenciais de prestação continuada ${ }^{256}$. O "Fundo Social de

255 REZENDE, Fernando. Brasil: conflitos federativos e reforma tributária. In: REZENDE, Fernando (coord.). Desafios do federalismo fiscal. Rio de Janeiro: Editora FGV, 2006, pp. 90-92. O mesmo autor explica por que o governo central optou pela utilização crescente das contribuições: "O recurso às contribuições sociais para sustentar o ajuste fiscal foi incentivado por três razões principais. Uma, de cunho federativo - a descentralização do poder de instituir e administrar os impostos e o aumento da parcela da arrecadação dos impostos federais transferida a estados e municípios, conforme o disposto na Constituição de 1988 não deixava outra alternativa. Outra, de natureza legal - as regras aplicadas às contribuições são muito frouxas do que as aplicadas aos impostos tradicionais. A terceira razão é de cunho administrativo - as contribuições são tributos bem mais fáceis de administrar e arrecadar". ( $O p$. cit., p. 92).

256 O Fundo Social de Emergência (FSE) foi instituído pela Emenda Constitucional de Revisão $\mathrm{n}^{\circ} 1$, de 01.03.1994 e vigorou para os exercícios financeiros de 1994 e 1995. Eis excerto do artigo $1^{\circ}$ da mencionada emenda: "Art. $1^{\circ}$ Ficam incluídos os arts. 71, 72 e 73 no Ato das Disposições Constitucionais Transitórias, com a seguinte redação: 'Art. 71. Fica instituído, nos exercícios financeiros de 1994 e 1995, o Fundo Social de Emergência, com o objetivo de saneamento financeiro da Fazenda Pública Federal e de estabilização econômica, cujos recursos serão aplicados no custeio das ações dos sistemas de saúde e educação, benefícios previdenciários e auxílios assistenciais de prestação continuada, inclusive liquidação de passivo previdenciário, e outros programas de relevante interesse econômico e social. Parágrafo único. [...] Art. 72. Integram o Fundo Social de Emergência: [...] IV vinte por cento do produto da arrecadação de todos os impostos e contribuições da União, excetuado o previsto nos incisos I, II e III; [...]"”. 
Emergência” (FSE) foi prorrogado até o final do exercício de 1999, mas já a partir de 1996 passou a se denominar "Fundo de Estabilização Fiscal" (FEF) ${ }^{257}$.

Desde o ano 2000 até os dias atuais, persiste a "Desvinculação de Recursos da União" (DRU), que substituiu os fundos anteriores e é responsável por livrar $20 \%$ da arrecadação da União no tocante a impostos, contribuições sociais e de intervenção no domínio econômico, permitindo que os recursos sejam destinados a outras despesas que não as estabelecidas originariamente pela Constituição Federal ${ }^{258}$.

257 De fato, com a Emenda Constitucional n ${ }^{\circ}$ 10, de 04.03.1996, o FSE foi prorrogado até 30.06.1997, passando a se chamar, a partir do início do exercício financeiro de 1996, Fundo de Estabilização Fiscal (FEF). Transcreve-se, a seguir, trecho do artigo $1^{\circ}$ da mencionada emenda: "Art. $1^{\circ} \mathrm{O}$ art. 71 do Ato das Disposições Constitucionais Transitórias passa a vigorar com a seguinte redação: 'Art. 71. Fica instituído, nos exercícios financeiros de 1994 e 1995, bem assim no período de $1^{\circ}$ de janeiro de 1996 a 30 de junho de 1997, o Fundo Social de Emergência, com o objetivo de saneamento financeiro da Fazenda Pública Federal e de estabilização econômica, cujos recursos serão aplicados prioritariamente no custeio das ações dos sistemas de saúde e educação, benefícios previdenciários e auxílios assistenciais de prestação continuada, inclusive liquidação de passivo previdenciário, e despesas orçamentárias associadas a programas de relevante interesse econômico e social. [...] $\S 2^{\circ} \mathrm{O}$ Fundo criado por este artigo passa a ser denominado Fundo de Estabilização Fiscal a partir do início do exercício financeiro de 1996. [...]"”.

Com o advento da Emenda Constitucional n ${ }^{\circ}$ 17, de 22 de novembro de 1997, o FEF foi prorrogado até 31 de dezembro de 1999, conforme previsão do artigo $1^{\circ}$ da referida emenda: "Art. $1^{\circ} \mathrm{O}$ caput do art. 71 do Ato das Disposições Constitucionais Transitórias passa a vigorar com a seguinte redação: 'Art. 71. É instituído, nos exercícios financeiros de 1994 e 1995, bem assim nos períodos de $1^{\circ}$ de janeiro de 1996 a 30 de junho de 1997 e $1^{\circ}$ de julho de 1997 a 31 de dezembro de 1999, o Fundo Social de Emergência, com o objetivo de saneamento financeiro da Fazenda Pública Federal e de estabilização econômica, cujos recursos serão aplicados prioritariamente no custeio das ações dos sistemas de saúde e educação, incluindo a complementação de recursos de que trata o $\S 3^{\circ}$ do art. 60 do Ato das Disposições Constitucionais Transitórias, benefícios previdenciários e auxílios assistenciais de prestação continuada, inclusive liquidação de passivo previdenciário, e despesas orçamentárias associadas a programas de relevante interesse econômico e social"'.

258 A DRU foi criada pela Emenda Constitucional n ${ }^{\circ} 27$, de 21 de março de 2000, acrescentando o artigo 76 ao Ato das Disposições Constitucionais Transitórias da Constituição de 1988. O mencionado artigo 76, atualmente, possui a seguinte redação: "Art. 76. É desvinculado de órgão, fundo ou despesa, até 31 de dezembro de 2011, 20\% (vinte por cento) da arrecadação da União de impostos, contribuições sociais e de intervenção no domínio econômico, já instituídos ou que vierem a ser criados até a referida data, seus adicionais e respectivos acréscimos legais. (Redação dada pela Emenda Constitucional n ${ }^{\circ} 56$, de 2007). $\S 1^{\circ}$ O disposto no caput deste artigo não reduzirá a base de cálculo das transferências a Estados, Distrito Federal e Municípios na forma dos arts. 153 , $5^{\circ} ; 157$, I; 158, I e II; e 159, I, $a$ e $b$; e II, da Constituição, bem como a base de cálculo das destinações a que se refere o art. 159, I, $c$, da Constituição. (Redação dada pela Emenda Constitucional n ${ }^{\circ} 42$, de 19.12.2003). § $2^{\circ}$ Excetua-se da desvinculação de que trata o caput deste artigo a arrecadação da contribuição social do salário-educação a que se refere o art. 212, § $5^{\circ}$, da Constituição. (incluído pela Emenda Constitucional n ${ }^{\circ} 27$, de 2000). § $3^{\circ}$ Para efeito do cálculo dos recursos para manutenção e desenvolvimento do ensino de que trata o art. 212 da Constituição, o percentual referido no caput deste artigo será de 12,5\% (doze inteiros e cinco décimos por cento) no exercício de 2009, 5\% (cinco por cento) no exercício de 2010, e nulo no exercício de 2011. (incluído pela Emenda Constitucional n ${ }^{\circ}$ 59, de 2009)". 
O problema é que todos os procedimentos acima apontados acabaram por gerar um círculo vicioso, cujo resultado foi praticamente a anulação da descentralização fiscal surgida com a Carta de 1988. Nesse sentido, Fernando Rezende ${ }^{259}$ esclarece:

A rigidez orçamentária cresceu, apesar da adoção de medidas para desvincular parte dos recursos arrecadados com o aumento das contribuições sociais. Com a adoção do FSE e sua posterior transformação na DRU, $20 \%$ das receitas arrecadadas com as contribuições sociais passaram a ficar disponíveis para financiar outros gastos e sustentar as metas estabelecidas para a geração de superávits primários nas contas da União. Assim, à medida que crescia a necessidade de gerar superávits mais elevados para evitar o crescimento desordenado da dívida pública, aumentava a arrecadação das contribuições, o que, por seu turno, abria espaços para o crescimento dos gastos amparados pela seguridade (a cada rodada de aumento das contribuições sociais, $80 \%$ dos recursos ficavam disponíveis para financiar o aumento desses gastos). Em consequiência, a receita de contribuições já supera a receita dos impostos de competência da União e seu crescimento fez com que o orçamento se tornasse mais rígido e a descentralização tributária perseguida em 1988 fosse revertida, principalmente no que concerne à participação dos estados no bolo tributário nacional.

Para conciliar a centralização das receitas com a descentralização do gasto - a maior parte da responsabilidade pela provisão dos serviços de saúde e assistência social cabe aos estados e municípios -, a saída foi expandir as transferências não-constitucionais, o que acentuou os desequilíbrios federativos e reduziu a liberdade de estados e municípios em matéria de alocação dos recursos orçamentários em virtude de essas transferências serem direcionadas a programas específicos. A rigidez orçamentária estendeu-se também a estados e municípios, afetando fortemente os seus investimentos. ${ }^{260}$

259 REZENDE, Fernando. Brasil: conflitos federativos e reforma tributária. In: REZENDE, Fernando (coord.). Desafios do federalismo fiscal. Rio de Janeiro: Editora FGV, 2006, pp. 93-94.

260 Fernando Rezende e José Roberto Afonso, em outro estudo (A Federação Brasileira: Fatos, Desafios e Perspectivas. jan. 2003, BNDES, pp. 15-16. Disponível em http://info.worldbank.org/etools/docs/library/229990/Rezende\%20e\%20Afonso.pdf, acessado em 19.11.2009. Também disponível em http://www.bndes.gov.br/SiteBNDES/export/sites/default/bndes_pt/Galerias/Arquivos/bf_bancos/e00024 26.pdf, acessado em 19.11.2009), complementam a conclusão (retrocesso da descentralização fiscal) ao examinar: "Na prática, a nova Constituição instalou um regime fiscal duplo. O tradicional, que atribuía poderes tributários na federação e criava mecanismos de participação nas receitas, e um novo, relacionado especificamente ao financiamento de políticas sociais, ao qual se aplicam normas mais frouxas. Uma vez que mais da metade das receitas arrecadadas pelos mais importantes tributos federais imposto de renda e imposto sobre produtos industrializados - seria transferida aos estados e municípios, o resultado era fácil de prever. As autoridades federais tiveram de contar cada vez mais com contribuições sociais para cumprir suas responsabilidades sociais, o que não somente interrompia a tendência à descentralização observada desde a metade dos anos 70, como também levou a uma deterioração indesejável na qualidade do sistema tributário brasileiro.

A deterioração das condições econômicas após a abertura do mercado brasileiro à competição externa não permitiu que estados e municípios exercessem plenamente a autonomia supostamente concedida pela descentralização política e fiscal. De um lado, uma taxa média baixa de crescimento econômico não permitiu que se concretizassem os ganhos de um aumento da competência para tributar e das transferências recebidas da União. De outro, a necessidade crescente de implantar a disciplina fiscal, a fim de evitar problemas macroeconômicos, acarretou restrições maiores à despesa, de tal modo que um instrumento dos mais importantes para o exercício do poder político nos estados e municípios - o orçamento - foi severamente afetado". 
Percebe-se, dessa forma, que a descentralização fiscal pretendida pela atual Constituição Federal restou prejudicada, provocando, ainda, a centralização de políticas em mãos do governo central.

Não se pode afirmar, realmente, que existe uma considerável descentralização de políticas no federalismo brasileiro, uma vez que grande parte dos gastos dos entes subnacionais refere-se a despesas vinculadas (educação e saúde, por exemplo), sejam elas legais ou constitucionais, ou é objeto de transferências do governo central para aplicação em objetivos específicos, o que obriga a destinação desses recursos para a finalidade destinada pela União. Os estados e municípios não possuem autonomia plena, pois não conseguem estabelecer, com a flexibilidade necessária, suas próprias políticas, já que não são capazes de financiá-las com recursos próprios.

É importante mencionar que o modelo acima representa apenas uma descentralização de funções, atuando os entes subnacionais, na maioria das vezes, como executores da política prescrita pelo poder central $^{261}$. Cria-se, assim, uma relação de dependência que é pérfida para a federação e põe em risco seu equilíbrio, incentivando a adoção de práticas clientelistas (até com características do coronelismo) pois, no mais das vezes, para a liberação de recursos pelo nível governamental superior, acaba-se valorizando mais a linha partidária do ente subnacional que solicita esses recursos do que, propriamente, a necessidade da região por determinada alocação de bens e serviços.

Bem por isso, essa combinação de estratégias (descentralização de funções e centralização de recursos em mãos do poder central) é muito prejudicial no tocante à

261 A respeito dessa questão, Fernando Rezende e José Roberto Afonso (A Federação Brasileira: Fatos, Desafios e Perspectivas. jan. 2003, BNDES, p. 17. Disponível em http://info.worldbank.org/etools/docs/library/229990/Rezende\%20e\%20Afonso.pdf, acessado em 19.11.2009. Também disponível em http://www.bndes.gov.br/SiteBNDES/export/sites/default/bndes_pt/Galerias/Arquivos/bf_bancos/e00024 26.pdf, acessado em 19.11.2009) explicam: "Na verdade, a provisão constitucional para descentralizar os gastos públicos com programas sociais foi afetada pela centralização das receitas reservadas para esse propósito. As contribuições sociais continuaram sendo de competência exclusiva do governo federal (com exceção das contribuições para o sistema de aposentadorias), que controlava as decisões sobre a arrecadação e a utilização desses recursos. Ainda que estudos empíricos mostrem que estados e municípios aumentaram o volume de recursos aplicados em atividades sociais - educação e saúde, principalmente - o grosso dos recursos financeiros necessários para melhorar a qualidade de vida vem das contribuições sociais arrecadadas pelo governo federal. (...)

Embora uma parte significativa da receita das contribuições sociais seja devolvida aos governos subnacionais por meio de negociações ad hoc (convênios), existem provisões especiais anexadas ao seu uso, o que significa que a autonomia deles é afetada. Além de não ter autonomia para dispor desses recursos, eles não têm garantia de sua liberação no tempo. Esses recursos estão sujeitos a revisões anuais e a mudanças nas relações políticas que não oferecem um terreno sólido para uma descentralização sustentável das responsabilidades do Estado em políticas sociais”. 
eficiência do gasto público, pois também abre espaço para a prática da corrupção e outros atos de desvio de recursos.

A impossibilidade de atribuir responsabilidades aos governantes é também um assunto que preocupa quando se adota esse modelo descentralizado de funções com alocação central de recursos, como ocorre na Itália. Nesses casos, não há incentivo para que os governantes façam alocação de recursos de forma eficiente; ao contrário, do ponto de vista da elegibilidade, seria muito mais vantajoso para os políticos o oferecimento de favores, com a utilização do aparato estatal, do que a preocupação com a eficiência do gasto público ou com eventual risco de represálias legais. Tal sistemática aumenta, inclusive, o número de candidatos que financiam suas campanhas eleitorais mediante a arrecadação de propinas. A preocupação dos governantes se volta mais à obtenção desses recursos do governo central do que à sua utilização de forma proveitosa ${ }^{262}$. Outro problema é que tal descentralização de funções aos governos locais - e com ela a transmissão de poder para atividades tais como a concessão de licenças, a formação de novo corpo administrativo e a escolha dos projetos que serão objeto de financiamento - faz com que o incentivo à corrupção aumente ${ }^{263}$.

Percebe-se, por tudo que foi acima mencionado, que o modelo brasileiro não apresenta equilíbrio entre os níveis que compõem a estrutura federal, uma vez que há clara predominância do poder nas mãos do governo central em detrimento dos demais entes subnacionais (Estados-membros e Municípios).

Não existe uma descentralização fiscal e de políticas significativas no federalismo brasileiro, denotando a falta de uma autonomia plena dos entes subnacionais.

262 Alfredo Del Monte e Erasmo Papagni. The determinants of corruption in Italy: Regional panel data analysis. In: European Journal of Political Economy, Forthcoming, 24 maio 2006. Disponível em: http://ssrn.com/abstract=903991, acessado em 16.07.2008. O trabalho pesquisa motivos que conduziram à corrupção na Itália no período de 1963 a 2001. No original: "Decentralization of functions and central allocation of resources made politicians irresponsible and reduced incentives to allocate resources efficiently. For politicians the probability of being elected was much more linked to the number of favori (favours) that they could offer their 'clients' than to the efficiency of public expenditure and the probability of being apprehended. Further, decentralization increased the number of politicians: the new entrants had to fund their own electoral campaigns and were driven to use resources from bribery to do so. As taxes and benefits were the exclusive domain of national government, local politicians were more interested in obtaining more resources from central government than using resources efficiently".

263 Alfredo Del Monte e Erasmo Papagni. The determinants of corruption in Italy: Regional panel data analysis. In: European Journal of Political Economy, Forthcoming, 24 maio 2006. Disponível em http://ssrn.com/abstract=903991, acessado em 16.07.2008. "The decentralization of functions from central governments to local governments (the power to issue licences, the power to hire new staff, the power to choose the projects to finance, etc.) increased the opportunities for corruption". 
Essa estrutura do federalismo brasileiro deflagra consequências importantes, dentre elas a necessidade cada vez maior de os entes subnacionais se valerem de recursos do governo central, com efeitos práticos no orçamento federal, provocando situações que incentivam o desvio de recursos ${ }^{264}$.

\subsection{O controle do endividamento dos entes subnacionais e ainda}

\section{questão da autonomia}

A autonomia reduzida dos entes subnacionais também pode ser depreendida a partir da análise do controle exercido sobre esses entes em relação aos seus respectivos endividamentos. A esse respeito, a Lei de Responsabilidade Fiscal (artigos 29 a 42) e as Resoluções do Senado ${ }^{265}$ traçam diversas condicionantes e limitações para a realização de operações de crédito pelos Estados e Municípios, bem como para a concessão de garantia pelos mesmos entes em operações de crédito internas ou externas ${ }^{266}$.

Os Estados ou Municípios que não observam os limites de endividamento previstos na mencionada lei e nas Resoluções do Senado têm como impedimentos, dentre outros, a impossibilidade de realizarem novas operações de crédito (internas ou externas), inclusive por antecipação de receita, bem como a de obterem transferências voluntárias da União ou

264 Os detalhes dessas situações serão tratados no capítulo quatro do presente estudo.

265 O artigo 52 da Constituição Federal estabelece que é de competência privativa do Senado Federal: “(...) $\mathrm{V}$ - autorizar operações externas de natureza financeira, de interesse da União, dos Estados, do Distrito Federal, dos Territórios e dos Municípios; VI - fixar, por proposta do Presidente da República, limites globais para o montante da dívida consolidada da União, dos Estados, do Distrito Federal e dos Municípios; VII - dispor sobre limites globais e condições para as operações de crédito externo e interno da União, dos Estados, do Distrito Federal e dos Municípios, de suas autarquias e demais entidades controladas pelo Poder Público federal; VIII - dispor sobre limites e condições para a concessão de garantia da União em operações de crédito externo e interno; IX - estabelecer limites globais e condições para o montante da dívida mobiliária dos Estados, do Distrito Federal e dos Municípios; (...)”. Com base no permissivo constitucional, o Senado Federal editou a Resolução ${ }^{\circ} 40$, de 20 de dezembro de 2001, que dispõe sobre os limites globais para o montante da dívida pública consolidada e da dívida pública mobiliária dos Estados, do Distrito Federal e dos Municípios. Também editou a Resolução $n^{\circ} 43$, de 25 de dezembro de 2001, que dispõe sobre as operações de crédito interno e externo dos Estados, do Distrito Federal e dos Municípios, inclusive no tocante à concessão de garantias, seus limites e condições de autorização.

266 Segundo a definição da própria Lei de Responsabilidade Fiscal (art. 29, inciso III), operação de crédito é o "compromisso financeiro assumido em razão de mútuo, abertura de crédito, emissão e aceite de título, aquisição financiada de bens, recebimento antecipado de valores provenientes da venda a termo de bens e serviços, arrendamento mercantil e outras operações assemelhadas, inclusive com o uso de derivativos financeiros". A assunção, o reconhecimento ou a confissão de dívidas pelo ente federativo também se equiparam a operação de crédito (art. 29, § $1^{\circ}$, da Lei de Responsabilidade Fiscal). 
do Estado (artigo 31, da Lei de Responsabilidade Fiscal) ${ }^{267}$. Somente a aplicação desse último impedimento é capaz de provocar importante limitação à atuação eficiente de entes subnacionais que não possuem recursos próprios e suficientes para fazer frente às suas políticas e aos seus encargos.

As propostas de endividamento dos estados e municípios são levadas à apreciação da Secretaria do Tesouro Nacional (STN) para análise e posterior encaminhamento - caso aprovadas - para a Comissão de Assuntos Econômicos (CAE) do Senado, onde é designado um relator, cujo relatório será encaminhado à sessão plenária da mesma Casa para aprovação ou não.

Paulo Arvate, Ciro Biderman e Marcos Mendes analisam, justamente, o momento em que a proposta é encaminhada ao Senado. Tentam averiguar se, até a aprovação pelo plenário, é possível que haja manejo político com a finalidade de atrasar ou acelerar o procedimento de aprovação do pedido de endividamento. Sustentam que, embora quase todos os pleitos sejam aprovados, há uma diferença considerável entre os prazos de aprovação desses pedidos, com sinais de que fatores políticos influenciam no prazo de $\operatorname{tramitação}^{268}$ :

A principal conclusão deste artigo é que alguns fatores políticos se encontram correlacionados com o prazo de aprovação no Senado. Diversas variáveis mostraram coeficientes não-significativos. As variáveis consistentemente correlacionadas com o prazo de aprovação são a ligação política entre o governador do Estado solicitante e o relator; e o acúmulo excessivo de solicitações nos seis meses anteriores a um novo pedido. Quando o governador e o relator pertencem à mesma coalizão, o processo se acelera. Se o relator pertencer à mesma coalizão que o governador, mas ocorrer uma mudança que encerre essa ligação (por exemplo, uma mudança de relator, sendo o novo relator não-pertencente à coalizão do governador), o processo passa a tramitar mais devagar. Interpretamos esse resultado como evidência de comportamento oportunista por parte de alguns senadores ou, em jargão de teoria dos jogos, como evidência de ausência de cooperação entre governadores e relatores que não pertençam à mesma coalizão política.

$[\ldots]$

267 Para uma análise mais aprofundada a respeito da dívida pública e operações de crédito, ver OLIVEIRA, Regis Fernandes de (Dívida Pública e Operações de Crédito. In: Revista Tributária e de Finanças Públicas. São Paulo, ano 12, jul-ago de 2004, n. 57, Academia Brasileira de Direito Tributário (ABDT), Editora Revista dos Tribunais, pp. 201-220); CONTI, José Maurício (Arts. 32 a 39. In: MARTINS, Ives Gandra da Silva; NASCIMENTO, Carlos Valder do (org.). Comentários à Lei de Responsabilidade Fiscal. São Paulo: Saraiva, 2001, pp. 217-246); BALEEIRO, Aliomar (Uma introdução à ciência das finanças. $16^{\mathrm{a}}$ ed., atual. por Dejalma de Campos. Rio de Janeiro: Forense, 2004, pp. 459-522); ROSA JR., Luiz Emygdio F. da (Manual de direito financeiro \& direito tributário. $16^{\mathrm{a}}$ ed. atual. Rio de Janeiro: Renovar, 2002, pp. 115-135).

268 Aprovação de empréstimos a governos subnacionais no Brasil: há espaço para comportamento político oportunista? In: Revista de Ciências Sociais, Rio de Janeiro, v. 51, n. 4, 2008, pp. 983 a 1014. 
Se o prazo de uma solicitação estiver correlacionado com determinados fatores políticos que caracterizam cada solicitação (como a coincidência na coalizão ou no partido entre o Estado do governador solicitante e o relator; ter ou não ter ligações políticas com o presidente; entre outros), isso pode ser evidência de que o mecanismo de controle de dívidas não é neutro. Ou, em outras palavras, que pode ser influenciado por fatores políticos.

Entendemos por 'fatores políticos' aqueles que levam a negociações não associadas com o objetivo principal do mecanismo de controle sobre endividamento (preservar a liquidez e a solvência das contas públicas), em que a prerrogativa senatorial de 'criar dificuldades' para aprovação de uma solicitação é usada por senadores para 'vender facilidades'. Não falamos aqui de corrupção, mas do uso do mecanismo de controle de dívidas para obter ganhos políticos, como uma manipulação oportunista à luz do ciclo eleitoral, conforme mostra a literatura. Por exemplo, um aumento dos recursos para seu próprio Estado ou uma posição vantajosa em disputas eleitorais vindouras. ${ }^{269}$

Deduz-se que no procedimento de aprovação do pedido de endividamento dos entes subnacionais há fatores de favorecimento ao intercâmbio clientelar ou à troca de favores entre os senadores, desviando-se o objeto principal do mencionado procedimento para discussões outras, como o benefício a bases eleitorais e linhas partidárias.

Desvirtua-se, dessa forma, a finalidade do Senado, que é a de, precisamente, propiciar o equilíbrio da federação, controlando "o endividamento dos Estados, assegurando que alguns poucos não imponham ao restante do país o ônus de um endividamento excessivo" ${ }^{270}$. Ao se desviar desse objetivo, o Senado não só põe em risco as contas públicas nacionais, como também se afasta do interesse público que deveria perseguir.

Importante mencionar, ainda, que as restrições impostas pela Lei de Responsabilidade Fiscal, embora surgidas como resposta a um contexto de franca indiferença e imprudência fiscais dos entes da federação - principalmente a imprudência dos estados -, levaram os entes subnacionais a dependerem cada vez mais de recursos oriundos do poder central, abrindo espaço, mais uma vez, para relações clientelistas e de corrupção ${ }^{271}$.

269 ARVATE, Paulo; BIDERMAN, Ciro; MENDES, Marcos. Aprovação de empréstimos a governos subnacionais no Brasil: há espaço para comportamento político oportunista? In: Revista de Ciências Sociais, Rio de Janeiro, v. 51, n. 4, 2008, pp. 986 e 992.

270 ARVATE, Paulo; BIDERMAN, Ciro; MENDES, Marcos. Aprovação de empréstimos a governos subnacionais no Brasil: há espaço para comportamento político oportunista? In: Revista de Ciências Sociais, Rio de Janeiro, v. 51, n. 4, 2008, pp. 987-988.

271 Outras implicações em relação à ausência de autonomia dos entes subnacionais serão melhor expostas no capítulo quatro do presente trabalho. 


\subsection{A assimetria da federação brasileira e a descentralização política}

A concentração de poderes na União faz transparecer outra constatação: a assimetria no federalismo brasileiro. De fato, o acúmulo de poder no governo central acaba por retirar boa fração de autonomia dos entes subnacionais, impedindo que eles adotem uma postura administrativa, política e financeira flexível, condizente com suas reais necessidades.

Além disso, esse fato é agravado diante da grande diferença existente entre os governos regionais, situação que tem como origem a grande extensão territorial brasileira e as diversidades econômicas inerentes a cada região. Nesse sentido, Marcelo Figueiredo ${ }^{272}$ bem retrata a questão ao expor:

Em síntese, a simetria formal de nosso modelo de federação não condiz com a assimetria real de nossas unidades federadas. Nossos Estados-Membros são muito diferentes entre si.

E essa grande diferença entre eles e as várias regiões do Brasil deveriam ser levadas em conta para compreender as suas peculiaridades e a partir delas conferir flexibilidade políticoadministrativa ao conhecer e enfrentar os seus problemas e demandas.

Lamentavelmente sempre oscilamos entre um centralismo federal e uma pálida autonomia reconhecida aos Estados-Membros. O Brasil sempre praticou uma federação assimétrica.

Não há espaços verdadeiramente autônomos no federalismo brasileiro dedicado aos EstadosMembros. Nossa cultura centralizadora permeia as instituições. Falta-nos a cultura federalista reconhecendo as peculiaridades de cada Estado e Região do País.

A ausência de equilíbrio na federação brasileira é claramente percebida, igualmente, ao se analisar a situação dos municípios. A atual Carta Constitucional os erigiu à categoria de entes federados; contudo, a autonomia dedicada aos Municípios é bastante limitada não só em relação à União, como também no tocante aos Estados e ao Distrito Federal.

Apesar dessas limitações, não é correta a afirmação de que os Municípios brasileiros não seriam entes federados por não possuírem Poder Judiciário próprio e por não terem a possibilidade de exercer participação na vontade global do Estado Federal - situação essa diversa dos Estados-membros, os quais exercem essa atribuição por intermédio de representação no Senado Federal.

A afirmação é contestada, sob o aspecto formal, diante do que prescreve o artigo 18 da Constituição Federal, o qual preceitua que "a organização político-administrativa da República Federativa do Brasil compreende a União, os Estados, o Distrito Federal e os

272 Federalismo x Centralização. A eterna busca do equilíbrio - A tendência mundial de concentração de poderes na União. A questão dos governos locais. In: Interesse Público. Porto Alegre: Notadez, ano 9, $\mathrm{n}^{\circ}$ 41, jan-fev de 2007, p. 107. 
Municípios, todos autônomos, nos termos desta Constituição". O artigo $1^{\circ}$ da mesma Constituição é categórico ao estabelecer que "a República Federativa do Brasil, formada pela união indissolúvel dos Estados e Municípios e do Distrito Federal, constitui-se em Estado Democrático de Direito".

A questão da ausência de representação na vontade geral da federação representa apenas mais uma limitação à autonomia dos municípios, realçando a existência de um federalismo assimétrico, sem desconfigurar, todavia, o modelo federativo. Quanto à necessidade de um Poder Judiciário, tal exigência não representa requisito para considerar um ente como pertencente ou não à federação. O que se impõe, na verdade, é que o próprio Estado federal possua esse órgão, cuja atribuição será a de controlar a constitucionalidade das leis, com vistas a manter a integridade do modelo federativo. Verifica-se, dessa forma, que os municípios integram a federação, embora não possuam a autonomia desejável.

Na federação brasileira é possível afirmar que até mesmo a descentralização política não apresenta o equilíbrio desejável, principalmente no aspecto referente à representação dos Estados no legislativo federal.

O Brasil adota o bicameralismo, como é próprio dos países que estão adstritos à estrutura federal e como a tradição histórica contida nas Constituições brasileiras, desde 1824, vem confirmando ${ }^{273}$. Significa, assim, que o Congresso Nacional é composto da Câmara dos Deputados e do Senado Federal (artigo 44 da Constituição Federal), possuindo ambas as Casas a função de exercer o Poder Legislativo.

O Senado Federal é composto por representantes dos Estados e do Distrito Federal. Cada Estado-membro elege três senadores para um mandato de oito anos (artigo 46, § $1^{\circ}$, da Constituição Federal). Não se perquire o número de habitantes do ente federado, nem sua importância econômica, pois a representação deve ser a mesma (três senadores) para cada um desses entes. Ocorre que, diante das peculiaridades do Brasil, essa representação torna-se desigual, uma vez que existe grande número de Estados nas regiões menos desenvolvidas do

273 José Afonso da Silva (Comentário contextual à Constituição. São Paulo: Malheiros, 2005, pp. 386-387), no entanto, ressalta que a Constituição de 1934 apresentava o "unicameralismo imperfeito" ou o "bicameralismo desigual", uma vez que, embora existentes as duas Casas, somente à Câmara dos Deputados era atribuído o exercício do Poder Legislativo, participando o Senado apenas como colaborador. Daí concluir que, "sob certos aspectos, pois, havia unicameralismo; sob outros, bicameralismo". 
país (Norte, Nordeste e Centro-Oeste), representando apenas $43 \%$ da população total do país, mas com domínio de $74 \%$ dos votos do Senado ${ }^{274}$.

Os representantes do povo, eleitos de forma proporcional à população do Estado, constituem a Câmara dos Deputados (artigo 45, caput, da Constituição); já os representantes dos próprios Estados-membros (aí incluído o Distrito Federal) compõem o Senado Federal (artigo 46, caput, da Constituição).

No tocante à Câmara dos Deputados, a desigualdade de tratamento entre os Estados já é percebida a partir da leitura do parágrafo primeiro, do artigo 45, da Constituição Federal, o qual não estabelece o número total de deputados que comporão a Câmara (matéria a ser estabelecida por lei complementar), mas disciplina que nenhuma das unidades da federação poderá ter "menos de oito ou mais de setenta Deputados".

A limitação tem influência negativa direta em relação aos Estados com grande índice demográfico, os quais terão o número de representantes restringidos a setenta, não importando quantas vezes supere a quantidade de habitantes de Estados com menor índice demográfico ${ }^{275}$. A desproporção é clara, conforme ressalta José Afonso da Silva ${ }^{276}$ :

274 A Federação Brasileira: Fatos, Desafios e Perspectivas. Jan. 2003, BNDES, p. 12. Disponível em http://info.worldbank.org/etools/docs/library/229990/Rezende\%20e\%20Afonso.pdf, acessado em 19.11.2009. Também disponível em http://www.bndes.gov.br/SiteBNDES/export/sites/default/bndes_pt/Galerias/Arquivos/bf_bancos/e00024 26.pdf, acessado em 19.11.2009. O trabalho dos autores é de 2003; no entanto, segundo dados do Instituto Brasileiro de Geografia e Estatística (IBGE) do ano de 2007, as percentagens indicadas no trabalho dos autores, no tocante à representação populacional por regiões da federação, permanecem as mesmas. Veja-se: a) população recenseada e estimada do Brasil: 183.987.291; b) população da Região Norte: 14.623.316 (8\%); c) população da Região Nordeste: 51.534 .406 (28\%); d) população da Região Sudeste: 77.873 .120 (42\%); e) população da Região Sul: 26.733 .595 (15\%); f) população da Região $\begin{array}{llll}\text { Centro-Oeste: } & 13.222 .854 & (7 \%) . & \text { Disponível }\end{array}$ http://www.ibge.gov.br/home/estatistica/populacao/contagem2007/contagem_final/tabela1_1.pdf, acessado em 19.11.2009.

Nesse sentido, Fernando Rezende e José Roberto Afonso (A Federação Brasileira: Fatos, Desafios e Perspectivas. Jan. 2003, BNDES, p. $12 . \quad$ Disponível em http://info.worldbank.org/etools/docs/library/229990/Rezende\%20e\%20Afonso.pdf, acessado em 19.11.2009. Também disponível em http://www.bndes.gov.br/SiteBNDES/export/sites/default/bndes_pt/Galerias/Arquivos/bf_bancos/e00024 26.pdf, acessado em 19.11.2009) esclarecem: “A descentralização política também foi favorecida por esta Constituição, que deu novo impulso ao desequilíbrio na representação dos estados no legislativo federal. A partir de 1988, os estados pobres e menos populosos tiveram direito a um mínimo de oito representantes na Câmara de Deputados, enquanto que os estados maiores ficavam com um teto máximo de 70 representantes. Essas condições levaram a uma super-representação do Norte e uma subrepresentação do Sudeste. A região Norte, que tem $8 \%$ da população do país, ficou com 14,5\% dos assentos, enquanto que o Sudeste, com $43 \%$ da população, detém apenas 32,2\% das cadeiras. Em casos extremos, o número de votos necessários para eleger um deputado nos estados mais desenvolvidos é dezesseis vezes maior do que nos estados menos desenvolvidos e populosos". 
Essa regra, que consta do art. $45, \S 1^{\circ}$, é fonte de graves distorções do sistema de representação proporcional nele mesmo previsto para a eleição de deputados federais, porque, com a fixação de um mínimo de 8 deputados e o máximo de 70, não se encontrará meio de fazer um proporção que atenda ao princípio do voto com valor igual para todos, consubstanciado no art. 14, que é aplicação particular do princípio democrático da igualdade de direitos de todos perante a lei. É fácil ver que um Estado com 400 mil habitantes terá 8 representantes, enquanto um de 30 milhões terá apenas 70, o que significa um deputado para cada 50 mil habitantes (1:50.000) para o primeiro, e 1 para 428.571 para o segundo (1:428.571).

Em qualquer Matemática isso não é proporção, mas brutal desproporção. (...)

Desprestigia-se, com isso, a representação dos Estados com maior número de habitantes, notadamente os da região Sudeste do país, enquanto os da região Norte, que possuem poucos habitantes, apresentam uma quantidade excessiva de deputados. A vontade da população desses Estados, que deveria ser manifestada por intermédio de uma representação proporcional, acaba não se concretizando.

Fernando Rezende e José Roberto Afonso argumentam "que em casos de enormes desigualdades regionais internas, uma representação desse tipo pode-se justificar, uma vez que põe a questão regional na agenda nacional"277.

Ocorre, porém, que no Brasil ainda não existem instituições fortes descentralizadas para permitir que determinadas regiões apresentem um poder de decisão maior que outras. $\mathrm{Na}$ verdade, a desigualdade apontada tanto no âmbito do Senado quanto no da Câmara dos Deputados beneficia o surgimento de canais para a prática do clientelismo, do coronelismo e da corrupção, justamente em face dos representantes dos estados que possuem maior poder de decisão no Congresso Nacional.

Nessas situações, há quem propugne um maior centralismo político - a exemplo do que ocorre com a China, em que o centralismo é exercido por intermédio do Partido Comunista - como forma de promover o desenvolvimento do país e evitar a atuação de grupos de pressão e a prática de desvios de recursos no âmbito dos governos locais e regionais $^{278}$.

277 A Federação Brasileira: Fatos, Desafios e Perspectivas. Jan. 2003, BNDES, pp. 12-13. Disponível em http://info.worldbank.org/etools/docs/library/229990/Rezende\%20e\%20Afonso.pdf, acessado em 19.11.2009. Também disponível em http://www.bndes.gov.br/SiteBNDES/export/sites/default/bndes_pt/Galerias/Arquivos/bf_bancos/e00024 26.pdf, acessado em 19.11.2009.

278 Olivier J. Blanchard e Andrei Shleifer (Federalism with and without political centralization. China versus Russia. Fev. 2000. MIT Dept. of Economics Working Paper n. 00-15; Harvard Institute of Economics Research Paper n. 1889. Disponível em http://ssrn.com/abstract=236127, acessado em 
Olivier J. Blanchard e Andrei Shleifer afirmam, nesse ponto, que "os benefícios econômicos da descentralização, obtidos a partir do federalismo, dependem fundamentalmente de alguma forma de centralização política" e complementam que, "sem tal centralização, os incentivos para perseguir políticas regionais são muito altos e não podem ser eliminados somente por intermédio de engenhosos arranjos econômicos e fiscais", 279 .

Da mesma forma, Daniel Treisman argumenta que "se deve ter cuidado ao descentralizar o poder político em países com baixo nível de desenvolvimento que são vulneráveis à corrupção"280.

Não se admite, aqui, que a saída para o problema do Brasil seja a do centralismo político, mesmo porque ele poderia trazer ainda mais consequências e inconvenientes, principalmente ao processo democrático do país.

Os próprios Olivier J. Blanchard e Andrei Shleifer reconhecem que a centralização não é a solução única; admitem a possibilidade de um país federal "harmonizar-se sem centralização política, como a Rússia fez nos anos 90 e o Brasil e a Índia têm realizado há mais tempo", mas sustentam que "algum sistema político de organização dos interesses políticos nacionais e regionais é necessário para ir além dessa harmonia"281.

Defende-se, em vez da centralização política, um maior equilíbrio da federação por intermédio de uma representação equitativa dos entes subnacionais na esfera legislativa e em todos os âmbitos da federação, como forma de torná-la realmente simétrica. Dificultar-se-ia,

16.07.2008) defendem esse entendimento no caso da Rússia, onde os governos locais dificultam, inclusive por intermédio da corrupção, o crescimento de novas empresas no país.

279 Federalism with and without political centralization. China versus Russia. Fev.-2000. MIT Dept. of Economics Working Paper n. 00-15; Harvard Institute of Economics Research Paper n. 1889, p. 12. Disponível em http://ssrn.com/abstract=236127, acessado em 16.07.2008. Tradução livre do autor. No original: "As best we can tell, the economic benefits of decentralization obtained from federalism rely crucially on some form of political centralization. Without such centralization, the incentives to pursue regionalist policies are too high, and cannot be eliminated solely through clever economic and fiscal arrangements".

280 The Causes of Corruption: A Cross-National Study. In: Journal of Public Economics, Elsevier Science S.A., 2000, v. 76, n. 3, p. 441. Tradução livre do autor. No original: "If this interpretation is correct, it suggests a reason for caution in decentralizing political power in countries at low levels of development that are vulnerable to corruption".

281 Federalism with and without political centralization. China versus Russia. Fev.-2000. MIT Dept. of Economics Working Paper n. 00-15; Harvard Institute of Economics Research Paper n. 1889, p. 12. Disponível em http://ssrn.com/abstract=236127, acessado em 16.07.2008. Tradução livre do autor. No original: "It is possible that a federal country can muddle through without political centralization, as Russia has done in the 1990s and Brazil and India have done for longer, but some political system of aligning the interests of national and regional politicians is needed to get beyond muddling through". 
dessa forma, a atuação de grupos de pressão sobre parlamentares que representam os estados e se evitaria o incentivo à prática do clientelismo e da corrupção.

\subsection{A competição vertical no federalismo fiscal brasileiro e a autoridade compartilhada na elaboração de políticas}

A União adquiriu, com a atual Constituição Federal, amplos poderes em matéria de competência. Foi-lhe assegurada, conforme visto anteriormente, competência material exclusiva (artigo 21, da CF); competência legislativa privativa (artigo 22); competência comum com Estados, Distrito Federal e Municípios (artigo 23); e competência legislativa concorrente com os Estados e Distrito Federal (artigo 24).

Percebe-se que tanto nas hipóteses de competência comum quanto nas de competência legislativa concorrente, a União não atua de forma isolada, pois há a possibilidade da participação simultânea de outros entes da federação. Há, desse modo, a possibilidade de uma atuação compartilhada entre as esferas governamentais na elaboração de políticas.

Para as prestações de serviço de competência comum, qualquer ente pertencente à federação poderá atuar sem o afastamento da competência do outro ${ }^{282}$. São exemplos de serviços que podem ser prestados no âmbito da competência comum dos entes federados: a) prestação de saúde e assistência pública; b) proteção e garantia das pessoas portadoras de deficiência; c) promoção dos meios de acesso à cultura, educação e ciência; d) fomento à produção agropecuária; e) promoção de programas de construção de moradias; f) aprimoramento das condições habitacionais e de saneamento básico; g) combate às causas da pobreza $^{283}$.

No que se refere à competência concorrente, cabe à União legislar sobre normas gerais, o que não exclui a competência suplementar dos Estados. Dentre as matérias objeto de legislação concorrente entre União, Estados e Distrito Federal, estão as seguintes: a) direito tributário, financeiro, penitenciário, econômico e urbanístico; b) produção e consumo;

282 José Afonso da Silva (Comentário contextual à Constituição. São Paulo: Malheiros, 2005, p. 273) esclarece que a competência comum "significa que a prestação do serviço por uma entidade não exclui igual competência de outra - até porque aqui se está no campo da competência-dever, porque se trata de cumprir a função pública de prestação de serviços à população".

283 O artigo 23, caput, da Constituição Federal, contém a relação completa de todos os serviços que podem ser prestados pelos entes federados. 
c) educação, cultura, ensino e desporto; d) previdência social, proteção e defesa da saúde; e) proteção e integração social das pessoas portadoras de deficiência; f) organização, garantias, direitos e deveres das Polícias Civis ${ }^{284}$.

O problema que surge diante das estruturas acima traçadas é a possibilidade de a concorrência vertical entre os entes federados provocar efeitos contrários à própria finalidade do federalismo.

A ausência de coordenação dessas estruturas permite que a atuação concomitante das esferas de governo acabe por gerar uma excessiva prestação de serviços em determinada área de maior interesse do ente ou pior, a insuficiência de serviços que não constituem objeto de conveniência política da esfera governamental. Vislumbra-se inclusive a hipótese de o poder central aguardar a atuação do ente subnacional e vice-versa, podendo chegar ao extremo da não disponibilização do serviço à coletividade.

Nas poucas oportunidades em que a Constituição Federal viabiliza a descentralização de políticas pelos entes subnacionais, estes atuam, muitas vezes, com ineficiência, justamente diante da ausência de coordenação para uma atuação compartilhada entre os próprios entes ${ }^{285}$.

Marcos Mendes ${ }^{286}$ trata dessas nuances ao comentar:

(...) existem, no federalismo brasileiro, diversas áreas em que os três níveis de governo atuam simultaneamente. Até que ponto isso pode gerar a competição vertical? Nas principais áreas de ação compartilhada - saúde e educação - não parece haver esse tipo de problema. As

284 O artigo 24, caput, da Constituiição Federal, contém a relação completa de todos os serviços que podem ser prestados pelos entes federados.

285 Gilberto Bercovici (Dilemas do Estado Federal Brasileiro. Porto Alegre: Livraria do Advogado Editora, 2004, pp. 66-67) também aborda a questão e afirma que a ausência de coordenação e planejamento prejudicou a pretendida descentralização de encargos aos entes subnacionais: "Nem todos os autores reconhecem a existência de um amplo processo de descentralização de receitas e encargos. No entanto, após a Constituição de 1988, de modo lento, inconstante e descoordenado, os Estados e Municípios vêm substituindo a União em várias áreas de atuação (especialmente nas áreas da saúde, educação, habitação e saneamento), ao mesmo tempo em que outras esferas estão sem qualquer atuação governamental graças ao abandono promovido pelo Governo Federal. Política esta, de abandono de políticas sociais por parte do Governo Federal, denominada, por Maria Hermínia Tavares de Almeida [Federalismo e Políticas Sociais. Revista Brasileira de Ciências Sociais n 28, São Paulo, ANPOCS, junho de 1995, pp. 104-105] e Marta Arretche [Mitos da Descentralização: Mais Democracia e Eficiência nas Políticas Públicas? Revista Brasileira de Ciências Sociais n 31, São Paulo, ANPOCS, junho de 1996, p. 64, nota 17], de 'descentralização por ausência'. Esta transferência não planejada e descoordenada de encargos contradiz o lugar-comum de que os entes federados receberam apenas verbas, e não encargos com a nova ordem constitucional. As políticas sociais não sofreram mudanças qualitativas ou se deterioraram não pela sua concentração na esfera federal, mas pela total falta de planejamento, coordenação e cooperação no processo de descentralização".

286 Federalismo fiscal. ARVATE, Paulo; BIDERMAN, Ciro (org.). Economia do setor público no Brasil. Rio de Janeiro: Elsevier, 2004, pp. 459-460. 
políticas estão hierarquizadas e as funções de cada nível de governo razoavelmente estabelecidas. O que acontece com mais freqüência nessas áreas é uma tentativa de repassar os custos para outras esferas de governo. Tanto é assim que foi preciso estabelecer, na Constituição, dispositivos que obrigam cada nível de governo a realizar um gasto mínimo em educação e saúde.

Uma área em que há evidências de competição vertical e oferta excessiva de serviços é a assistência social. Abundam nos três níveis de governo programas de geração de emprego e renda e de bolsas assistenciais, embora sejam claras as limitações desse tipo de programa quando ofertados por governos locais. Ocorre que o apelo eleitoral de programas sociais é bastante elevado. O eleitor, em especial o de baixa escolaridade, não está preocupado em discernir quem é o responsável pela política de geração de emprego, renda e assistência social. E o candidato que deseja se eleger não pode ignorar as principais demandas do eleitorado.

Outra dificuldade que advém da atuação compartilhada das esferas governamentais é a incapacidade de os eleitores identificarem e responsabilizarem as autoridades pela atuação na prestação de serviços públicos. Como o serviço pode ser prestado tanto pela União quanto pelos Estados e Municípios, torna-se custoso ao cidadão comum identificar qual é o responsável pela ausência ou falha na prestação do serviço.

Nesse sentido, de acordo com Jonathan Rodden, "quando a descentralização envolve acrescentar camadas de governo e expandir áreas de responsabilidade compartilhada, pode facilitar a transferência de 'culpa' ou de créditos políticos, na prática reduzindo a accountability" ${ }^{287}$, esta definida por Ricardo Lobo Torres como a "responsabilidade pela eficiente gerência de recursos públicos" 288 .

Depreende-se que a ausência de parâmetros estabelecendo a atuação clara de cada ente pode tornar ineficiente a prestação de serviços públicos no âmbito da competência comum e concorrente, gerando incertezas na definição da esfera governamental responsável pela realização do encargo e problemas de accountability, abrindo oportunidades para a ocorrência de corrupção e outras práticas de desvio de recursos.

Bem por isso é que Marcelo Figueiredo ${ }^{289}$ propõe, como forma de evitar esses problemas, a viabilização da aplicação do disposto no artigo 23, parágrafo único, da atual

287 Federalismo e descentralização em perspectiva comparada: sobre significados e medidas. Tradução de Miriam Adelman e Marta Arretche. In: Revista de Sociologia e Política, jun. 2005, n. 24, Curitiba, p. 21. Também disponível em http://www.scielo.br/scielo.php?pid=S010444782005000100003\&script=sci_arttext\&tlng=, acessado em 17.07.2008.

288 Tratado de direito constitucional financeiro e tributário: o orçamento na Constituição. $2^{\mathrm{a}}$ ed., rev. e atual. Rio de Janeiro: Renovar, 2000, v. 5, p. 308.

289 Federalismo x Centralização. A eterna busca do equilíbrio - A tendência mundial de concentração de poderes na União. A questão dos governos locais. In: Interesse Público. Porto Alegre: Notadez, ano 9, $\mathrm{n}^{\circ}$ 41, jan-fev de 2007, pp. 105-106. 
$\operatorname{Carta}^{290}$, que prevê a criação de lei complementar para estabelecer diretrizes para a cooperação entre todos os níveis federados, com vistas ao equilíbrio do desenvolvimento e do bem-estar em âmbito nacional.

Entendimento similar é o exposto por Gilberto Bercovici, para quem "a descentralização deve ser realizada de maneira articulada, não conflitiva, como vem ocorrendo", sugerindo como solução o planejamento, a cooperação e a coordenação "entre União e entes federados, com os objetivos do desenvolvimento e da promoção da igualação das condições sociais de vida, não com o desmonte puro e simples ou o retrocesso da recentralização de receitas na esfera federal",291.

Importante ressaltar que, da forma como tais competências estão previstas na Constituição Federal e são exercidas atualmente, o poder ainda permanece concentrado em mãos do governo central.

\subsection{A competição horizontal no federalismo fiscal brasileiro}

A competição horizontal, ou seja, aquela que ocorre entre entes governamentais de mesmo nível, pode trazer vários benefícios à federação, como sustentavam Wallace Eugene Oates e Charles M. Tiebout ${ }^{292}$, permitindo que a população se desloque para a área que melhor atenda seu padrão de preferência por serviços públicos.

Referida competição também é considerada pela doutrina como forte instrumento para promover a cultura da accountability e, em consequência, criar mecanismos para a redução da corrupção ${ }^{293}$. Sobre esse aspecto, Guzin Gulsun Arikan afirma que "os benefícios da descentralização vão além do conhecido ganho proveniente de uma melhor competição entre os gastos públicos e as preferências dos indivíduos", mas podem significar, também,

290 Dispositivo introduzido por intermédio da Emenda Constitucional no 53, de 19 de dezembro de 2006.

291 Dilemas do Estado Federal Brasileiro. Porto Alegre: Livraria do Advogado Editora, 2004, p. 69. O autor também reitera, a propósito, a necessidade de lei complementar a disciplinar a questão: "É a falta de uma política nacional coordenada, e não a repartição de competências concorrentes e comuns, que faz com que determinados programas e políticas públicas sejam realizados por mais de uma esfera governamental e outros por nenhuma. Falta de coordenação e cooperação esta que, emblematicamente, revela-se na ausência da lei complementar prevista no parágrafo único do artigo 23 da Constituição, que deve regulamentar as normas para a cooperação entre a União e os entes federados". (Op. cit., p. 72).

292 Vide item 1.6.1, em que se expõe o princípio do benefício e a função fiscal alocativa, bem como as teorias de Wallace Eugene Oates e Charles M. Tiebout.

293 Robin Boadway e Anwar Shah. Fiscal federalism: principles and practices of Multiorder Governance. New York: Cambridge University Press, 2009, p. 534. No original: "Competition among Local Governments. Competition for mobile factors of production reinforces the accountability culture. Such enhanced accountability has the potential to reduce corruption (Weingast, 1995; Arikan, 2000)". 
"uma redução na corrupção pública, com os burocratas de uma economia descentralizada fiscalmente menos capazes de se envolver num comportamento caçador de rendas"294.

\subsubsection{A dificuldade em estabelecer a competição horizontal entre os municípios brasileiros}

No Brasil, não é possível a estruturação de uma competição horizontal eficiente no âmbito dos municípios, tendo em vista a relativa autonomia desses entes e a dependência deles por recursos provenientes das esferas governamentais superiores, o que impede que os governos locais instituam sua própria política de gastos com fins à disputa entre entes de mesmo nível ${ }^{295}$.

De acordo com Fernando Rezende e José Roberto Afonso, “o aumento decorrente na dependência dos estados e grandes municípios de recursos da União para atender demandas básicas de seus habitantes diminuiu as possibilidades de que pessoas e empresas lucrassem com a competição entre jurisdições na alocação das despesas" ${ }^{\text {296. }}$; além disso, as próprias normas ditadas pelo poder central, quanto aos serviços públicos sociais, "levaram a uma maior padronização dos gastos públicos, ao mesmo tempo em que as condições vinculadas

294 Fiscal Decentralization: A Remedy for Corruption? International Tax and Public Finance, mar. $2004, \mathrm{v}$. 11, n. 2, Kluwer Academic Publishers, p. 192. Tradução livre do autor. No original: "If confirmed by additional research, this finding would suggest that the benefits of decentralization go beyond the well known gains from a better match between public spending and consumer preferences, as identified by Tiebout (1956). The benefits may include a reduction in public corruption, with bureaucrats in a fiscally decentralized economy less able to engage in rent-seeking behavior”. O mesmo G. Gulsun Arikan ( $O p$. cit., p. 176) afirma que, num arcabouço de competição tributária, o número de competições entre esferas governamentais de mesmo nível provoca resultados inversamente proporcionais ao incremento da corrupção. No original: "In the analysis, fiscal decentralization is modeled as an increase in the number of competing jurisdictions within a tax-competition model, with jurisdictional corruption being captured by rent-seeking behavior. Comparative-static analysis shows that as the number of competing jurisdictions rises, the level of 'corrupt earnings' (tax revenue appropriated by bureaucrats) falls". Nesse sentido, Fernando Rezende e José Roberto Afonso (A Federação Brasileira: Fatos, Desafios e Perspectivas. Jan. 2003, BNDES, p. 29. Disponível em http://info.worldbank.org/etools/docs/library/229990/Rezende\%20e\%20Afonso.pdf, acessado em 19.11.2009. Também disponível em http://www.bndes.gov.br/SiteBNDES/export/sites/default/bndes_pt/Galerias/Arquivos/bf_bancos/e00024 26.pdf, acessado em 19.11.2009) atestam que, "com exceção da capital do estado e algumas outras áreas urbanas importantes, as receitas próprias representam menos de $20 \%$ das receitas municipais, significando que a clássica abordagem de Tiebout da competitividade no nível local não se aplica ao caso brasileiro".

296 A Federação Brasileira: Fatos, Desafios e Perspectivas. Jan. 2003, BNDES, p. 30. Disponível em http://info.worldbank.org/etools/docs/library/229990/Rezende\%20e\%20Afonso.pdf, acessado em 19.11.2009. Também disponível em http://www.bndes.gov.br/SiteBNDES/export/sites/default/bndes_pt/Galerias/Arquivos/bf_bancos/e00024 26.pdf, acessado em 19.11.2009. 
ao acesso a empréstimos das instituições financeiras federais também reduziam a autonomia dos governos estaduais e municipais" 297 .

Somada a essa constatação, com o advento da Constituição Federal de 1988, houve a criação de vários municípios menores, muitos deles sem condições sequer de instituir seus próprios tributos, ou seja, o custo para arrecadar e cobrar os impostos constitucionalmente previstos não compensaria sua instituição pela municipalidade.

Muitos desses municípios dependem hoje das transferências oriundas dos níveis governamentais superiores, principalmente dos recursos do Fundo de Participação dos Municípios (FPM). Devido a esse fato, também não há como viabilizar qualquer disputa horizontal entre tais governos locais.

A competição horizontal é importante porque promove maiores condições de accountability e participação popular na política local, dificultando os incentivos à prática de desvio de recursos públicos. No âmbito dos governos locais, essa disputa é ainda mais importante e proveitosa, uma vez que os impostos inerentes aos municípios (imposto sobre a propriedade, principalmente) são os que podem ser melhor percebidos e fiscalizados pelos cidadãos, inclusive sobre o destino dado à sua arrecadação.

No caso do Brasil, uma reforma com vistas a aumentar a porcentagem de recursos próprios dos municípios, aliada a um fortalecimento das instituições, poderia promover uma eficaz disputa horizontal entre governos locais e diminuir o estímulo ao desvio de recursos.

\subsubsection{A competição horizontal entre os estados e a questão da guerra fiscal}

Devido à carência de recursos nos estados, estes se esforçam por obter fontes de receitas, mesmo que seja necessária a disputa entre esferas governamentais de mesmo nível. Uma das maneiras de angariar recursos é o aparelhamento de incentivos com o fim de atrair investimentos na base territorial desses estados, assegurando a prospecção de receitas futuras e o desenvolvimento da região.

O estímulo ao investimento é proporcionado por intermédio de isenções, redução de alíquotas de tributos, concessão de empréstimos a juros abaixo do mercado etc. Ocorre que

\footnotetext{
297 A Federação Brasileira: Fatos, Desafios e Perspectivas. Jan. 2003, BNDES, p. 30. Disponível em http://info.worldbank.org/etools/docs/library/229990/Rezende\%20e\%20Afonso.pdf, acessado em 19.11.2009. Também disponível em http://www.bndes.gov.br/SiteBNDES/export/sites/default/bndes_pt/Galerias/Arquivos/bf_bancos/e00024 26.pdf, acessado em 19.11.2009.
} 
na maioria das vezes tal disputa pode ocasionar externalidades negativas, produzindo efeitos prejudiciais ao equilíbrio da federação.

É justamente o que ocorre no âmbito dos estados brasileiros, nos quais a competição horizontal se realiza por intermédio da base tributária do ICMS (imposto sobre operações relativas à circulação de mercadorias e sobre prestações de serviços de transporte interestadual e intermunicipal e de comunicação). Nesse caso, acontece uma verdadeira "guerra fiscal" entre os governos regionais, os quais, ao perseguirem mais recursos para seus respectivos territórios, mediante a concessão de diversos incentivos a empresas, acabam provocando desarmonia no aparato federativo. Na mencionada disputa, o poder central é incapaz de atuar como coordenador eficiente para evitar prejuízos e desequilíbrios à federação ${ }^{298}$.

Os próprios habitantes dos estados onde ocorre a competição horizontal são atingidos, uma vez que além de financiarem essa disputa - deixando de receber outros serviços públicos de maior necessidade - suportam a majoração da carga tributária, necessária para fazer frente à compensação pelos estímulos fiscais dirigidos às empresas. Referida compensação, inclusive, é determinada pela Lei de Responsabilidade Fiscal, com o intuito de incentivar o compromisso com a boa administração das finanças públicas estaduais $^{299}$.

298 Não por acaso, Guilherme Bueno de Camargo (A guerra fiscal e seus efeitos: autonomia x centralização. In: CONTI, José Mauricio (org.). Federalismo fiscal. Barueri: Manole, 2004, pp. 203-204) ressalta que "a guerra fiscal, portanto, nada mais é do que a generalização de uma competição entre entes subnacionais pela alocação de investimentos privados por meio da concessão de benefícios e renúncia fiscal, conflito este que se dá em decorrência de estratégias não cooperativas dos entes da Federação e pela ausência de coordenação e composição dos interesses por parte do governo central". Da mesma forma, André Elali ( $O$ federalismo fiscal brasileiro e o sistema tributário nacional. São Paulo: MP Editora, 2005, p. 81) define guerra fiscal "como a disputa entre os entes federativos pela atração de investimentos para seus territórios através da concessão de incentivos fiscais (sob diferentes ordens como, por exemplo, isenções, diferimentos, reduções de bases de cálculo, etc.)".

299 A compensação está prevista no artigo 14, inciso II, da Lei de Responsabilidade Fiscal, que determina outros procedimentos para que haja a concessão de incentivos às empresas: "Art. 14. A concessão ou ampliação de incentivo ou benefício de natureza tributária da qual decorra renúncia de receita deverá estar acompanhada de estimativa do impacto orçamentário-financeiro no exercício em que deva iniciar sua vigência e nos dois seguintes, atender ao disposto na lei de diretrizes orçamentárias e a pelo menos uma das seguintes condições: I - demonstração pelo proponente de que a renúncia foi considerada na estimativa de receita da lei orçamentária, na forma do art. 12, e de que não afetará as metas de resultados fiscais previstas no anexo próprio da lei de diretrizes orçamentárias; II - estar acompanhada de medidas de compensação, no período mencionado no caput, por meio do aumento de receita, proveniente da elevação de alíquotas, ampliação da base de cálculo, majoração ou criação de tributo ou contribuição. § $1^{\circ}$ A renúncia compreende anistia, remissão, subsídio, crédito presumido, concessão de isenção em caráter não geral, alteração de alíquota ou modificação de base de cálculo que implique redução discriminada de tributos ou contribuições, e outros benefícios que correspondam a tratamento diferenciado. $\S 2^{\mathrm{o}} \mathrm{Se}$ o ato de concessão ou ampliação do incentivo ou benefício de que trata o caput deste artigo decorrer da condição contida no inciso II, o benefício só entrará em vigor quando 
O método citado para atrair empresas seria justificável, até certo ponto, se as consequências fiscais permanecessem adstritas ao âmbito do mesmo ente governamental que concede os benefícios $^{300}$. Significa afirmar que a medida adotada somente seria salutar para a federação se os incentivos (apesar das compensações, tal como o aumento da carga tributária) realmente granjeassem empresas para o estado e aumentassem o nível de desenvolvimento da região (com mais empregos, por exemplo), mas não interferissem diretamente nas finanças dos outros entes de mesmo nível.

O fato, porém, é que essa interferência ocorre. Como mencionado anteriormente, a disputa entre os estados ocorre por meio de seu principal tributo, o ICMS, o qual incide sobre o consumo. Parte da cobrança desse tributo ocorre na origem - seu fato gerador é a saída da mercadoria do estabelecimento do contribuinte, circunstância essa que define a competência para sua cobrança ${ }^{301}$ - e os estados possuem a prerrogativa de fixar as bases do imposto e de, também, modificar a legislação para viabilizar os incentivos fiscais às empresas.

Os estímulos concedidos às empresas têm, realmente, a faculdade de atraí-las para se instalarem nos estados, mas o ente que outorga essa vantagem acaba por "exportar parte da carga tributária para contribuintes de outros estados"302, justamente porque o tributo é cobrado na origem. De fato, como lembra Guilherme Bueno de Camargo, "pela sistemática atual de tributação na origem, mesmo uma empresa que exportasse a outros Estados toda a

implementadas as medidas referidas no mencionado inciso. $\S 3^{\circ} \mathrm{O}$ disposto neste artigo não se aplica: I às alterações das alíquotas dos impostos previstos nos incisos I, II, IV e V do art. 153 da Constituição, na forma do seu $\S 1^{\text {ó}}$; II - ao cancelamento de débito cujo montante seja inferior ao dos respectivos custos de cobrança".

300 Fez-se a mencionada ressalva ("até certo ponto"), uma vez que outros inconvenientes podem ser percebidos no âmbito do próprio ente governamental que concede os incentivos, conforme bem retratam Marcelo Piancastelli e Fernando Perobelli (ICMS: evolução recente e guerra físcal. Brasília, Ipea Instituto de Pesquisa Econômica Aplicada, fev. 1996, texto para discussão n. 402, p. 26. Também disponível em http://www.portalfederativo.gov.br/pub/Inicio/EstudosFederativos/td_0402.pdf, acessado em 23.11.2009): "Uma vez que todos os estados adotam os mesmos instrumentos, os benefícios fiscais e creditícios tendem a se anular, deixando de atuar como fatores contribuintes para a decisão locacional. De outro lado, aos estados resta uma perda de receita fiscal generalizada sem que se tenha, primeiro, avaliado o custo e o benefício do investimento. Ainda, ocorre realocação de recursos públicos, por meio da abdicação de receita, em favor de setores nem sempre prioritários. Finalmente, os estados sofrem agravamento da própria situação financeira, com a conseqüente redução dos investimentos e do atendimento das necessidades básicas da população".

301 No que se refere à circulação de mercadorias, o fato gerador do ICMS é justamente a saída dessa mercadoria do estabelecimento do contribuinte. Assim esclarece Salete Oro Boff (Reforma tributária e federalismo: entre o ideal e o possível. Porto Alegre: Sergio Antonio Fabris Editor, 2005, p. 137): "Deve-se destacar, de igual modo, o local da ocorrência do fato gerador, tendo em vista que ele é que determinará a competência para a cobrança. A opção do local de ocorrência determinar o local de tributação é escolha feita pelo Brasil de tributar na 'origem' do fato gerador, diversamente das tributações que assumem como fato gerador o local de destino da mercadoria, elegendo como princípio a tributação no "destino","

302 Marcos Mendes. Federalismo fiscal. In: ARVATE, Paulo; BIDERMAN, Ciro (org.). Economia do setor público no Brasil. Rio de Janeiro: Elsevier, 2004, p. 457. 
sua produção, deixaria no Estado onde estivesse localizada uma parcela significativa da arrecadação do ICMS",303.

A situação acima explica o motivo pelo qual a guerra fiscal provoca tantas incongruências e externalidades no âmbito da federação ${ }^{304}$.

Além disso, o fato de a maioria dos estados adotarem a mesma prática para conquistar investimentos praticamente retira o sentido da função alocativa com a finalidade de alcançar o princípio do benefício ("voto com os pés") ${ }^{305}$. Perde-se a razão, também, das vantagens advindas da competição horizontal, que é a de promover a qualidade e alocação eficiente dos gastos públicos.

Depreende-se que a parca autonomia concedida aos estados não é utilizada de forma satisfatória para proporcionar o equilíbrio do federalismo. A competição predatória, como a proporcionada pela guerra fiscal, lança relações nefastas nas quais é a plenitude da federação a mais prejudicada.

De outro lado, a ausência de coordenação do poder central, bem como sua incapacidade de proporcionar políticas regionais de desenvolvimento - principalmente com vistas a organizar e planejar o desenvolvimento industrial no Brasil -, permite a manutenção dessas práticas no âmbito dos estados ${ }^{306}$.

303 A guerra fiscal e seus efeitos: autonomia x centralização. In: CONTI, José Mauricio (org.). Federalismo fiscal. Barueri: Manole, 2004, p. 207.

304 Não por acaso, a competição predatória ocasionada pela guerra fiscal é denominada de race to the bottom ou seja, "corrida ao fundo do poço".

305 Vide item 1.6.1. Nesse sentido, Marcelo Piancastelli e Fernando Perobelli (ICMS: evolução recente e guerra fiscal. Brasília, Ipea - Instituto de Pesquisa Econômica Aplicada, fev. 1996, texto para discussão n. $402, \quad$ p. 26.4 Também em http://www.portalfederativo.gov.br/pub/Inicio/EstudosFederativos/td_0402.pdf, acessado em 23.11.2009) descrevem que, "uma vez que todos os estados adotam os mesmos instrumentos, os benefícios fiscais e creditícios tendem a se anular, deixando de atuar como fatores contribuintes para a decisão locacional".

306 A respeito da necessidade de o poder central exercer o papel de coordenador do desenvolvimento regional, Ricardo Varsano (A guerra fiscal do ICMS: quem ganha e quem perde. Rio de Janeiro, 1998, Ipea - Instituto de Pesquisa Econômica Aplicada, jun. 1997, texto para discussão n. 500, p. 5. Também disponível em http://www.portalfederativo.gov.br/pub/Inicio/EstudosFederativos/td_0500.pdf, acessado em 23.11.2009) esclarece: "É certamente, aceitável, em face da dinâmica do desenvolvimento, que se incluam entre os objetivos da política industrial a desconcentração da produção e o desenvolvimento regional e que se utilizem recursos públicos com estas finalidades. Tais objetivos, no entanto, são necessariamente nacionais e, por isso, devem ser perseguidos sob a coordenação do governo central. Quando, através da guerra fiscal, estados tentam assumir esse encargo, o resultado tende a ser desastroso. Primeiro, os vencedores das guerras fiscais são, em geral, os estados de maior capacidade financeira, que vêm a ser os mais desenvolvidos, com maiores mercados e melhor infra-estrutura. Segundo, ao renunciar à arrecadação, o estado está abrindo mão ou da provisão de serviços (educação, saúde, a própria infraestrutura etc.) que são insumos do processo produtivo ou do equilíbrio fiscal, gerando instabilidade macroeconômica". 
Aspecto importante a ser analisado é em que medida a guerra fiscal favorece o surgimento de práticas corruptas ou de desvio de recursos públicos.

Na maioria das vezes, na concessão de benefícios fiscais, o estado não realiza estudo aprofundado ou planejamento com o intuito de verificar as vantagens econômicas e financeiras com a instalação de determinada empresa em seu território; ao contrário, "com raras exceções, os benefícios fiscais e creditícios para investimentos são concedidos indistintamente a todos os setores" 307.

Salvo as regras expostas na Lei de Responsabilidade Fiscal (artigo 14), que obrigam o ente federado a estimar o impacto orçamentário-financeiro dos incentivos e a compensar eventuais estímulos que representem renúncia de receita, não há qualquer obrigação para o ente de demonstrar, detalhadamente, o motivo pelo qual se está dirigindo benefícios a esta ou aquela empresa.

Abre-se, assim, um acesso importante ao rent-seeking, ao clientelismo e à corrupção, com o favorecimento a empresas (por meio de renúncia fiscal ou de vantagens creditórias) em troca de benefícios pessoais (dentre eles, os eleitorais) ao governante ou aos representantes da Administração, tudo em detrimento do interesse público.

Ademais, tendo em vista que é comum a "realocação de recursos públicos, por meio da abdicação de receita, em favor de setores nem sempre prioritários"308, torna-se difícil averiguar, no caso concreto, se o oferecimento de incentivos à empresa tem realmente pretensão de promover o desenvolvimento da região ou se existem, na verdade, motivos pessoais para sua concessão.

No tocante aos motivos eleitorais para a concessão de benefícios a empresas, Ricardo Varsano $^{309}$ constata que

307 Marcelo Piancastelli e Fernando Perobelli (ICMS: evolução recente e guerra fiscal. Brasília, Ipea Instituto de Pesquisa Econômica Aplicada, fev. 1996, texto para discussão n. 402, p. 26. Também disponível em http://www.portalfederativo.gov.br/pub/Inicio/EstudosFederativos/td_0402.pdf, acessado em 23.11.2009).

308 Marcelo Piancastelli e Fernando Perobelli (ICMS: evolução recente e guerra fiscal. Brasília, Ipea Instituto de Pesquisa Econômica Aplicada, fev. 1996, texto para discussão n. 402, p. 26. Também disponível em http://www.portalfederativo.gov.br/pub/Inicio/EstudosFederativos/td_0402.pdf, acessado em 23.11.2009).

309 A guerra fiscal do ICMS: quem ganha e quem perde. Rio de Janeiro, 1998, Ipea - Instituto de Pesquisa Econômica Aplicada, jul. 1997, texto para discussão n. 500, p. 6. Também disponível em http://www.portalfederativo.gov.br/pub/Inicio/EstudosFederativos/td_0500.pdf, acessado em 23.11.2009. 
O governador de um estado, como homem público que é, está certamente empenhado em atender aos interesses maiores da nação. Mas, até mesmo por dever de ofício, coloca os de seu estado acima daqueles e, no caso de conflito de interesses, certamente defenderá os de sua unidade, tendo como bandeira a autonomia dos entes federados. Ademais, é natural que se preocupe também com sua carreira política. Se a concessão de incentivos, ao menos na sua visão, traz benefícios para seu estado e, além disso, gera bons dividendos para seu projeto político pessoal, junta-se o útil ao agradável. Ele fatalmente os concederá, a despeito dos interesses nacionais, ainda mais quando estes se manifestam de forma difusa, como, por exemplo, eficiência econômica.

O problema está quando os interesses pessoais do governante, tal como o de obter benefícios eleitorais, encontram-se desvinculados dos interesses públicos e da própria coletividade que representa. Em outras palavras, o efeito nocivo à sociedade se dá no momento em que a concessão de benefícios às empresas serve de moeda de troca para o governante atingir proveito pessoal (angariar recursos para sua campanha eleitoral, obtenção de propinas etc.).

Aliás, a respeito dessas relações entre políticos e empresários, o ex-governador do estado do Rio Grande do Sul, Olívio Dutra, já em 2001 afirmava que a concorrência entre os estados "se transformou num ostensivo processo de aliciamento, incluindo visitas clandestinas a autoridades para assediar empresários em outros Estados”, acrescentando, ainda, que "a guerra fiscal é temperada com acusações de corrupção, resultante da falta de transparência nos acordos entre governos e grandes empreendimentos"310.

A situação torna-se ainda mais difícil quando inexistem instituições fortes e eficientes que impeçam o avanço da corrupção nesses casos, principalmente num ambiente descentralizado.

A característica do próprio tributo (ICMS) não permite padrões adequados para a accountability, uma vez que o contribuinte não é capaz de perceber, de maneira apropriada, a sistemática do imposto. Conforme apontam Maria Nazaré Lins Barbosa e Virgínia Talaveira Valentini Tristão, "quanto mais visível for o tributo utilizado no financiamento do gasto público, maior será a oposição dos cidadãos ao gasto desnecessário e ao desperdício do dinheiro público"311 . Como afirmado, o ICMS não permite essa visualização.

Com o intuito de dissolver a guerra fiscal entre os estados, várias propostas se apresentam. Algumas delas consistem na: a) alteração do local da tributação, de maneira a

310 A quem serve a guerra fiscal? O Estado de São Paulo, 12/03/2001, p. A-2.

311 Federalismo, Clientelismo e Reforma Fiscal. In: Caderno de Pesquisas em Administração, São Paulo, v. 1, n. $8,1^{\circ}$ trimestre de 1999 , p. 68. Também disponível em www.ead.fea.usp.br/cad-pesq/arquivos/c8Art6.pdf, acessado em 17.07.2008. 
considerar não o lugar da origem, mas o do destino para fins de cobrança do ICMS; b) unificação, no governo central, dos três impostos sobre o consumo (ICMS, $\operatorname{IPI}^{312}$ e ISSQN $^{313}$ ); c) instituição da cobrança do ICMS pela União e futuro repasse do produto dessa arrecadação aos estados; d) criação de uma legislação uniforme para o ICMS, em âmbito nacional, com a finalidade de impedir que os entes estaduais estabeleçam alíquotas, bases de cálculo, isenções ou quaisquer outras vantagens para atrair investimentos ${ }^{314}$.

O importante é que o advento de eventual alteração da legislação, com a finalidade de extinguir a competição horizontal predatória entre os estados, tenha como objetivo precípuo promover a cooperação entre esses entes, aumentar sua autonomia (ou ao menos não reduzila ainda mais $)^{315}$ e, também, expungir os atuais mecanismos existentes que atraem os comportamentos caçadores de renda, o clientelismo e a corrupção.

\subsection{A necessidade de se repensar a federação e o federalismo fiscal brasileiros}

O federalismo brasileiro é estruturado sobre uma nação que apresenta desigualdades regionais históricas nos âmbitos econômico, social e territorial. A função da federação é a de, justamente, promover a diminuição dessas desigualdades, estabelecendo o correto ajustamento e coordenação entre os entes que a compõem.

Como já mencionado no presente estudo, não existem idênticos sistemas federativos. Cada Estado, diante dessas mesmas peculiaridades (econômicas, sociais, territoriais, culturais etc.), formará diferentes estruturas federalistas, com maiores ou menores níveis de descentralização. Daí não haver coincidência exata entre o federalismo presente no Brasil e o de outros países.

312 Imposto sobre produtos industrializados.

313 Imposto sobre serviços de qualquer natureza.

314 Essa foi a intenção apresentada na PEC (Proposta de Emenda Constitucional) no 41/2003 à Câmara dos Deputados, no governo do Presidente Luis Inácio Lula da Silva. Por seu intermédio pretendeu-se a alteração da Constituição Federal para a unificação da legislação a respeito do ICMS, obstando a concessão de benefícios fiscais como forma de competição predatória entre estados. Sob esses aspectos, contudo, a mencionada PEC não se desenvolveu; em outras matérias das quais cuidava deu origem à Emenda Constitucional n ${ }^{\circ}$ 42, de 2003.

315 Deve-se ponderar que o ICMS constitui o principal tributo das esferas estaduais; além disso, o resultado de sua arrecadação é maior que a da maioria dos tributos dos outros integrantes da federação. Retirar essa parcela dos estados, sem a devida compensação, contribuirá para que a União, mais uma vez, exerça um poder cada vez maior sobre os demais entes federativos. 
Aliás, pode-se afirmar que cada Constituição brasileira apresenta um pacto federativo que não se ajusta exatamente ao anterior ou ao seu subsequente, mesmo porque as transformações políticas, econômicas, sociais e culturais têm influência no estabelecimento desse pacto, refletindo também na concepção das respectivas Constituições.

Exemplo disso é a Constituição Federal de 1988, a qual foi concebida num ambiente de revitalização democrática do país, iniciada com a dissolução da ditadura do regime militar. Esse clima proporcionou a expectativa do lançamento de novas bases para o federalismo brasileiro, com vistas a uma maior descentralização. De fato, mediante a forte pressão de governos estaduais e prefeitos sobre os constituintes, esse desiderato foi alcançado, estabelecendo-se em favor dos entes subnacionais uma maior descentralização fiscal e política.

Ocorre que, ainda hoje, a descentralização propugnada na Carta de 1988 não foi capaz de diminuir as desigualdades regionais. Em muitos casos percebe-se, também, a incapacidade do governo central em atuar como verdadeiro coordenador e solucionador dos conflitos federativos. Depreende-se, assim, que a proposta contida na atual Constituição não solucionou o problema federativo, favorecendo a construção de canais de incentivo ao desvio de recursos públicos e à corrupção.

Das observações contidas nos itens anteriores do presente estudo, é possível apontar pelo menos dois motivos que impediram o alcance dos objetivos pretendidos e serviram como incentivo ao desvio de recursos: a) a forma como tal descentralização ocorreu no caso brasileiro; b) o fato de algumas dimensões da mencionada descentralização terem se estabelecido sem o necessário e concomitante fortalecimento das instituições no país, o que acabou por prejudicar a accountability e a governança.

\subsubsection{A ausência de equilíbrio nas dimensões da descentralização brasileira}

Não se pode negar que a Constituição de 1988 pretendeu viabilizar a descentralização fiscal; basta lembrar que houve o aumento da participação dos entes subnacionais na receita pública, enquanto a do poder central diminuiu. Ocorre que, como visto no item 3.2, referida descentralização não se deu por intermédio de um planejamento estruturado, uma vez que a necessária descentralização de atribuições ou de encargos não se efetivou no mesmo nível e nem de forma clara. 
A inexistência do mencionado planejamento foi o motivo pelo qual - incentivado pelo aumento da dívida pública, a sobrecarga de atribuições dirigidas ao poder central e a consequente majoração da carga tributária - não se pôde evitar a quase nulidade da descentralização fiscal contida na Carta de 1988.

Importante esclarecer que a utilização de indicadores de descentralização fiscal, obtidos por intermédio do nível de participação dos governos subnacionais na receita e no gasto total, é um critério que não demonstra, na realidade, o grau de descentralização físcal no Brasil.

É que muitos desses gastos são provenientes de transferências de impostos federais e estaduais, dos fundos de participação e, ainda, de transferências negociadas entre entes da federação, não representando despesas oriundas de receitas próprias das esferas governamentais regionais e locais.

A descentralização fiscal pressupõe, na verdade, "alguma autonomia dos governos regionais e locais nas decisões de gasto e de arrecadação, de modo a conferir-lhes alguma responsabilidade perante os cidadãos daquelas circunscrições", ou seja, "estes recebem os benefícios implícitos nos gastos, mas também são os financiadores de pelo menos parte destes. Esta autonomia nas questões fiscais faz com que pelo menos parte do tamanho global dos orçamentos seja definida localmente" ${ }^{, 316}$.

A ausência de descentralização de políticas também é patente no federalismo fiscal brasileiro e é ocasionada por dois fatores principais. O primeiro consiste no fato de os entes subnacionais não possuírem a autonomia financeira suficiente para exercê-las, dependendo de recursos do poder central e das diretrizes estabelecidas por ele para fazer uso desses recursos. O segundo fator diz respeito à competição vertical, que faz com que a política de gastos seja ditada pelo poder central em detrimento da liberdade dos entes subnacionais para estabelecerem suas próprias políticas de gastos ${ }^{317}$.

316 GUEDES, Kelly Pereira; GASPARINI, Carlos Eduardo. Descentralização fiscal e tamanho do governo no Brasil. In: Economia Aplicada, Ribeirão Preto, v. 11, n. 2, abr-jun de 2007, pp. 307-308. Disponível em http://www.scielo.br/scielo.php?script=sci_arttext\&pid=S141380502007000200007\&lng=en\&nrm=iso, acessado em 25.11.2009.

317 Quanto à competência vertical, Celina Souza (Redemocratização, federalismo e gasto social no Brasil: tendências recentes. Petrópolis (RJ), 23-27 out. 1999, XXIV Encontro Anual da Associação Nacional de Pós-graduação em Ciências Sociais (ANPOCS), $\quad$ p. $12 . \quad$ Disponível em http://info.worldbank.org/etools/docs/library/232522/SouzaRedemocratizacao.pdf, acessado em: 26/11/2009) esclarece: "A Constituição de 1988 também aprovou outras medidas de fortalecimento dos governos subnacionais, mas manteve a tradição de reter grande parte do monopólio legislativo na esfera federal, limitando sobremodo a capacidade das esferas subnacionais de adotarem políticas próprias. Esse 
A inexistência, na prática, de uma descentralização fiscal e de políticas constitui terreno fértil para a instabilidade na federação. De fato, se estados e municípios são incapazes de ditar sua arrecadação e impor seus gastos, também não terão condições de proporcionar à federação uma competição horizontal eficiente, perdendo qualquer sentido o princípio do benefício e todas as vantagens da função fiscal alocativa ${ }^{318}$. Não se aplica completamente à realidade brasileira o princípio de que os serviços públicos relevantes devem ser custeados e prestados pelos entes subnacionais.

Referida instabilidade provoca, também, situações que facilitam atividades de desencaminhamento de recursos públicos. É que, por depender de recursos oriundos do poder central e de se obrigar a cumprir as políticas por ele estabelecidas, o ente subnacional não se sente estimulado a cuidar da qualidade do gasto público, mesmo porque seus habitantes não o veem como o responsável pela sua realização. Essa situação serve como incentivo para que os governantes das esferas locais e regionais se preocupem mais em estabelecer vínculos políticos clientelares (oferecimento de favores em troca de apoio político ou de votos) do que vínculos políticos programáticos (viabilização de políticas públicas, distribuídas de maneira universal e objetiva à população) ${ }^{319}$, por exemplo.

A maneira como se apresenta a descentralização política também é ingrediente importante que, aliado às demais dimensões de descentralização (fiscal e de políticas), provoca pérfidos efeitos à federação e à integridade dos recursos públicos no Brasil.

Nesse sentido, aliás, Sebastian Freille, M. Emranul Haque e Richard Kneller propugnam que a descentralização política depende da fiscal para se efetivar de forma coerente, e vice-versa. Não se estabelece uma oportuna descentralização fiscal sem a alteração da base constitucional ou da organização do governo. Caso não se consiga realizar

fato, em geral pouco lembrado, é um dos paradoxos do federalismo brasileiro e o distingue das demais Federações. A Constituição determina, por exemplo, que questões que estão na esfera da competência concorrente da União com os estados, tais como energia elétrica, trânsito, tráfego, minas, recursos minerais e educação dependem de legislação federal". No mesmo sentido é o entendimento de Marta Arretche (Federalismo. In: AVRITZER, Leonardo; ANASTASIA, Fátima (org.). Reforma política no Brasil. Belo Horizonte: Editora UFMG, 2006, p. 127): "Por outro lado, tem presença permanente no debate político a contestação do formato centralizado de organização federativa das competências comuns, pelo qual a União tem elevada ingerência na agenda social dos governos locais, limitando na prática sua autonomia para definir seus próprios programas. Argumenta-se que esta fere o princípio federativo da autonomia política, bem como limita a capacidade de os governos locais atenderem às demandas de seus cidadãos, adaptando-se às necessidades locais. Tais princípios orientam os debates internos à organização de cada política setorial e representam uma tensão permanente nas relações entre os níveis de governo no que diz respeito à distribuição de autoridade na prestação de serviços sociais".

318 A respeito do princípio do benefício e da função fiscal alocativa, vide item 1.6.1 do presente estudo.

319 Sobre a definição de vínculo político clientelar e vínculo político programático, ver item 2.3.2 deste trabalho. 
esse ajuste, abrir-se-ão caminhos para a corrupção como, por exemplo, os proporcionados mediante o direcionamento de valores a entes subnacionais que não possuem a autonomia necessária para instituir os próprios tributos ${ }^{320}$. Essa é a situação enfrentada pelo Brasil, que possui um histórico de forte concentração de poder no governo central e uma fraca autonomia dos entes subnacionais.

Outro exemplo de distorção na seara da descentralização política é a representação dos estados no Congresso Nacional brasileiro, como relatado no item 3.4. A subrepresentação de estados com maior número de eleitores e economicamente fortes em face da super-representação de estados com menor quantidade de eleitores e de pouca reputação econômica é fator relevante que demonstra o desequilíbrio na federação.

Como visto, tal sistemática é defendida por alguns sob o argumento de que, com ela, “as unidades economicamente mais frágeis ‘forçam' o sistema político, o governo federal e o Congresso a incluir eventualmente os problemas advindos das desigualdades regionais na agenda política nacional" ${ }^{, 321}$.

O problema é que isso não acaba ocorrendo, levando os governos estaduais a, inclusive, impedirem a implantação de projetos de interesse nacional. Sobre essa questão, importante estudo é realizado por Alfred Stepan ${ }^{322}$, que analisa a capacidade de a super-

320 Federalism, decentralisation and corruption. (junho 2007), pp. 30-31. Disponível em: http://ssrn.com/abstract=951110; acessado em 16.07.2008. No original: "Our results in this paper may provide a few insights regarding the policy debate on the effects of decentralisation. In particular, as we have seen, the positive effect of fiscal decentralisation on corruption seems to be larger when countries have a deeply rooted unitarist history. While this result seems to be not so intuitive, it is plausible that deepening fiscal decentralisation without changing the constitutional basis or government organization may indeed be associated to higher corruption. After all, delegating more money to local governments which may lack the autonomy to create taxes - as might the case in a strong unitary system -, may encourage bad governance and corruption. Furthermore, a growing number of unitary countries are resorting to local democratization processes via local elections or referenda voting. Our results suggest that a move to higher political decentralisation may have associated higher corruption particularly if the country is has a unitarist tradition and low levels of fiscal decentralisation. It should be noted, that according to our results, the existence of long-standing unitary system has both direct and indirect association with corruption. As these have opposite signs, the overall result is uncertain and essentially an empirical matter".

321 Celina Souza (Redemocratização, federalismo e gasto social no Brasil: tendências recentes. Petrópolis (RJ), 23-27 out. 1999, XXIV Encontro Anual da Associação Nacional de Pós-graduação em Ciências $\begin{array}{llllll}\text { Sociais } & \text { (ANPOCS), } & \text { p. } & 13 . & \text { Disponível } & \text { em }\end{array}$ http://info.worldbank.org/etools/docs/library/232522/SouzaRedemocratizacao.pdf, acessado em 26/11/2009). A mesma autora, porém, esclarece que esse argumento é polêmico na doutrina (Op. cit., p. 13).

322 Para uma nova análise comparativa do federalismo e da democracia: federações que restringem ou ampliam o poder do Demos. In: Dados - Revista de Ciências Sociais. Rio de Janeiro, v. 42, n. 2, 1999, pp. 593-634. Tradução de Vera Pereira. Título original: Toward a New Comparative Analysis of Democracy and Federalism: Demos Constraining and Demos Enabling Federations. Disponível em http://www.scielo.br/scielo.php?script=sci_arttext\&pid=S0011-52581999000200001\&lng=pt\&nrm=iso, acessado em 26.11.2009. 
representação de estados menores restringir o poder da maioria democrática (fenômeno denominado como demos constraining) e, além disso, incentivar o comportamento caçador de renda (rent-seeking) na federação, trazendo riscos à democracia:

(...) De fato, em uma forma de federalismo extremamente demos constraining, legisladores que representam menos de $10 \%$ do eleitorado podem constituir um grupo com poder de obstrução (blocking win-set). Nessas circunstâncias, ainda que favoráveis à lei por razões programáticas, esses legisladores podem ser estruturalmente seduzidos a tirar proveito de sua posição de bloco de obstrução para extrair vantagens 'de monopólio' (rent-seeking rewards). É evidente que pequenos grupos de obstrução, constitucionalmente encravados em um sistema federativo democrático, também acarretam graves problemas para a eqüidade do princípio de 'um cidadão, um voto'.

Portanto, do ponto de vista político, grupos com poder de obstrução incorporados na Constituição podem criar sérios problemas para o funcionamento legítimo e eficaz da democracia. Por exemplo, é possível que em um país, durante um longo período de tempo, exista uma grande maioria de líderes políticos, e uma grande maioria do eleitorado, que acreditam na necessidade de mudanças importantes. Mas, se a federação foi estruturada de modo a facilitar a formação de grupos de veto por parte de pequenas maiorias, a legitimidade e a eficácia da democracia poderiam ser prejudicadas por esses aspectos restritivos da maioria. Se muitos cidadãos acreditarem que um governo popular, que realiza políticas populares, está sendo bloqueado pelas próprias instituições da democracia (como acontece em uma variedade extremada de federalismo demos-constraining), é possível que isso crie uma situação na qual a maior parte da legislação não seja propriamente barrada, mas introduzida por decreto do Executivo, com um apoio difuso da opinião pública. Essa situação pode ser boa ou má para a eficácia, mas certamente não contribui para a consolidação democrática, que progride muito mais quando a aprovação das principais leis se faz de acordo com os procedimentos legislativos democráticos, e não à revelia deles.

A situação acima é justamente a que ocorre no Brasil, onde se procurou estabelecer a superação das desigualdades regionais por intermédio da descentralização política assimétrica entre os estados, quando se poderia buscar a compensação das disparidades regionais mediante a imposição de maior autonomia aos estados e uma melhor coordenação e planejamento por parte do poder central ${ }^{323}$.

${ }^{323}$ O próprio Alfred Stepan (Para uma nova análise comparativa do federalismo e da democracia: federações que restringem ou ampliam o poder do Demos. In: Dados - Revista de Ciências Sociais. Rio de Janeiro, v. 42, n. 2, 1999, pp. 593-634. Tradução de Vera Pereira. Título original: Toward a New Comparative Analysis of Democracy and Federalism: Demos Constraining and Demos Enabling Federations. Disponível em http://www.scielo.br/scielo.php?script=sci_arttext\&pid=S001152581999000200001\&lng=pt\&nrm=iso, acessado em 26.11.2009) reconhece a presença efetiva do demos constraining no Brasil: "Se isso acontece na Câmara dos Deputados dos Estados Unidos, em que a representação proporcional é muito próxima do princípio da igualdade (um cidadão, um voto), não é preciso ser 'um novo institucionalista' para perceber as implicações políticas do federalismo em um país que tem uma Câmara dos Deputados desproporcional como o Brasil, que por conta das prerrogativas do Senado vai para o extremo do continuum demos-constraining, e onde os eleitorados e os governadores que ajudam a enviar membros para a Câmara Alta têm suas próprias agendas e controlam recursos valorizados pelos senadores. O Brasil é uma nova democracia que tem lutado contra uma das piores distribuições de renda do mundo. Em 1996, a maioria da população manifestou-se favoravelmente por diversas vezes à realização de reformas e o presidente Fernando Henrique Cardoso, que também as 
O panorama torna-se mais crítico quando se constata que são justamente os estados mais pobres do Brasil, presentes nas regiões Norte, Nordeste e Centro-Oeste, que possuem um histórico de amplo domínio das elites locais e onde a prática clientelista e até o coronelismo prevalecem até os dias atuais ${ }^{324}$.

Com a sistemática adotada no Brasil, não se torna fácil estabelecer políticas de âmbito nacional, diante do poder de veto pertencente aos estados menores. A aplicação ampla dos princípios da distribuição centralizada e da compensação fiscal, bem como das funções fiscais distributiva e estabilizadora, estudadas no primeiro capítulo do presente estudo, resta muito prejudicada também, diante da impossibilidade de atuação plena do poder central $^{325}$. Nesse sentido, Alfred Stepan afirma que a Constituição brasileira "opera em uma direção diferente, uma vez que dá a cada estado poder enorme para influenciar políticas macroeconômicas, reduzindo, dessa forma, o poder do governo federal, eleito democraticamente para gerir a economia para todos os cidadãos"326.

apoiava, terminou o ano com índices de alta aprovação popular. Contudo, nem os 'gostos' dos cidadãos, nem os do presidente, conseguiram levar a cabo muitas reformas. Na Câmara Alta brasileira, um grupo de senadores que representa menos de $9 \%$ do eleitorado pode criar um grupo - um 'win-set' - capaz de obstruir a aprovação de importantes reformas legislativas.

Se as instituições da Câmara dos Deputados americana - mais igualitária - são capazes de produzir equilíbrios induzidos pela estrutura, o federalismo brasileiro, que se caracteriza por uma Câmara Alta de baixíssima proporcionalidade e por uma Câmara Baixa igualmente desproporcional, certamente contribui para a perpetuação estrutural do status quo".

324 Tal fato também foi objeto de apreciação por Alfred Stepan (Brazil's Decentralized Federalism: Bringing Government Closer to the Citizens? In: Daedalus, v. 129, n. 2, Brazil: The Burden of the past: The Promise of the Future, primavera-2000, The MIT Press on behalf of American Academy of Arts \& Sciences, p. 165. Também disponível em http://www.jstor.org/stable/20027632, acessado em 26.11.2009), que afirma: "Muita da super-representação dos estados do Nordeste, Norte e Centro-Oeste na legislatura federal brasileira tem sido justificada tradicionalmente sob o fundamento de que eles são mais pobres que os estados sub-representados do Sul e Sudeste. Mas há evidência de que muitos dos estados que são super-representados na legislatura federal são precisamente aqueles estados com particular distribuição desigual de renda e fortes tradições de controle oligárquico local" (tradução livre do autor). No original: "Much of the overrepresentation of the states of the North east, North, and Center-West in the Brazilian federal legislature has traditionally been justified on the grounds that they are poorer than the underrepresented states of the South and South east. But there is evidence that many of the states that are overrepresented in the federal legislature are precisely those states with particularly unequal income distribution and strong traditions of local oligarchic control".

325 Sobre essa questão, Celina Souza (Redemocratização, federalismo e gasto social no Brasil: tendências recentes. Petrópolis (RJ), 23-27 out. 1999, XXIV Encontro Anual da Associação Nacional de Pós$\begin{array}{lllllll}\text { graduação em } & \text { Ciências } & \text { Sociais } & \text { (ANPOCS), } & \text { p. } & \text { Disponível } & \text { em }\end{array}$ http://info.worldbank.org/etools/docs/library/232522/SouzaRedemocratizacao.pdf, acessado em 26/11/2009) esclarece que "os governos subnacionais desempenham um papel duplo e contraditório: eles atendem parcialmente às demandas sociais, mas constrangem os objetivos econômicos da coalizão governista. Esse duplo e contraditório papel impede a criação de condições para que as questões das desigualdades sociais e regionais possam ser encaminhadas nacionalmente".

326 Brazil's Decentralized Federalism: Bringing Government Closer to the Citizens? In: Daedalus, v. $129, \mathrm{n}$. 2, Brazil: The Burden of the past: The Promise of the Future, primavera-2000, The MIT Press on behalf of American Academy of Arts \& Sciences, p. 150. Também disponível em http://www.jstor.org/stable/20027632, acessado em 26.11.2009. Tradução livre do autor. No original: 
Lucio R. Rennó ${ }^{327}$ explica de forma detalhada que a função distributiva é, na verdade, direcionada por outros personagens que não exclusivamente o governo central, encaminhamento esse realizado por intermédio de relação clientelar:

(...) São as trocas de apoio por políticas distributivistas, na forma de emendas orçamentárias, que fazem com que o sistema político brasileiro funcione, mas esse funcionamento é subótimo, ineficiente. Pior, o Legislativo, principalmente pelos incentivos de caráter personalista e descentralizador do sistema eleitoral, foca muito mais na formulação de políticas localistas, de caráter clientelista, do que de políticas nacionais. As implicações, portanto, da troca de apoio entre o Legislativo e o Executivo é bastante prejudicial à democracia brasileira. Essas trocas favorecem a continuidade de práticas antigas, mas ainda arraigadas, de clientelismo, fisiologismo e patrimonialismo, que podem, em último caso, estar na base de práticas corruptas.

Até mesmo para exercer o governo, o poder central necessita realizar alianças; é o chamado "presidencialismo de coalizão" 328 , em que estão presentes três fatores, quais sejam, o presidencialismo, o multipartidarismo e o federalismo ${ }^{329}$. Nesse sistema destaca-se,

"Here, once again, Brazil's federal constitution operates in a different direction, since it gives the individual states enormous scope to influence macroeconomic policies, thereby reducing the power of the democratically elected federal government to manage the economy for all the citizens".

327 Críticas ao Presidencialismo de Coalizão no Brasil: Processos Institucionalmente Constritos ou Individualmente Dirigidos? In: AVRITZER, Leonardo; ANASTASIA, Fátima (org.). Reforma política no Brasil. Belo Horizonte: Editora UFMG, 2006, p. 264.

328 A expressão foi criada por Sérgio Henrique Hudson de Abranches (Presidencialismo de coalizão. O dilema institucional brasileiro. In: Dados - Revista de Ciências Sociais. Rio de Janeiro, v. 31, n. 1, 1988, pp. 5-38). Sobre o tema, ver também os trabalhos de: Fabiano Santos (Governos de Coalizão no Sistema Presidencial: O caso do Brasil sob a Égide da Constituição de 1988. In: AVRITZER, Leonardo; ANASTASIA, Fátima (org.). Reforma política no Brasil. Belo Horizonte: Editora UFMG, 2006, pp. 221-236); Fernando Limongi (Presidencialismo e Governo de Coalizão. In: AVRITZER, Leonardo; ANASTASIA, Fátima (org.). Reforma política no Brasil. Belo Horizonte: Editora UFMG, 2006, pp. 237-257); e Lucio R. Rennó (Críticas ao Presidencialismo de Coalizão no Brasil: Processos Institucionalmente Constritos ou Individualmente Dirigidos? In: AVRITZER, Leonardo; ANASTASIA, Fátima (org.). Reforma política no Brasil. Belo Horizonte: Editora UFMG, 2006, pp. 259-271).

329 Sérgio Henrique Hudson de Abranches (A democracia brasileira vai bem, mas requer cuidados: proposições sobre democracia brasileira e o presidencialismo de coalizão. Estudos e pesquisas $n^{\circ} 5$, XIII Fórum Nacional, Rio de Janeiro, maio 2001, INAE - Instituto Nacional de Altos Estudos, pp. 12-13. Disponível em www.forumnacional.org.br/trf_arq.php?cod=EP00050, acessado em 30.11.2009) relaciona as características do "presidencialismo de coalizão": "Mais precisamente, o presidencialismo de coalizão se caracteriza pelos seguintes componentes institucionais, de governança e de relacionamento Executivo/Legislativo: $1^{\circ}$. o sistema político brasileiro assenta-se em combinação bastante peculiar entre o governo presidencialista, o federalismo, o multipartidarismo, incentivos à formação de alianças e coligações eleitorais nas eleições proporcionais para o Parlamento e a formação do Executivo Federal por meio de 'grandes coalizões'; 2 . o federalismo brasileiro tem características, por seu caráter extensivo, similares ao dos Estados Unidos, porém é mais assimétrico e marcado por profunda heterogeneidade estrutural, a qual tem como um de seus principais componentes desigualdades e diferenças entre os estados, entre as regiões e no interior destas últimas; $3^{\circ}$. no plano político-partidário uma das características fundamentais desse 'federalismo assimétrico' reflete-se na grande diferenciação dos sistemas políticos locais e regionais, que se desdobram em um contínuo que varia do extremo de concentração ao extremo de fragmentação; $4^{\circ}$. os regimes federativos caracterizam-se por partidos mais heterogêneos, programaticamente difusos, com baixa disciplina partidária e baixo grau de responsabilidade perante suas bases eleitorais, independentemente do sistema eleitoral; $5^{\circ}$. em decorrência dos fatores mencionados no item anterior, os partidos tendem a se organizar mais como 
inclusive, a importância dos entes subnacionais regionais. De acordo com Valeriano Mendes Ferreira Costa, o apoio do governador estadual às candidaturas de deputados estaduais e federais faz com que ele tenha a desenvoltura necessária para formar coalizões no âmbito da Assembleia Legislativa de seu estado, bem como para intervir na atuação de sua bancada no Congresso Nacional, transformando-se, assim, em importante personagem para a aprovação de questões de interesse nacional ${ }^{330}$.

No "presidencialismo de coalizão", o presidente estrutura seu apoio por intermédio de distribuição de cargos (inclusive em Ministérios) a integrantes de partidos que possuem representação no Congresso, viabilizando, em troca, a aprovação de sua agenda política naquela Casa. Tal prática, de acordo com Sérgio Hudson de Abranches, "não é imoral, se não envolver corrupção e práticas lesivas ao interesse público" ${ }^{\text {,31. }}$.

O problema, porém, é que da forma como é realizada no Brasil, incentiva justamente a prática da corrupção e atos de clientelismo. Nesse sentido, Lucio R. Rennó esclarece que “a construção de maiorias legislativas é tarefa difícil no Brasil e passa, necessariamente, pela troca de recursos econômicos, como emendas orçamentárias e cargos na burocracia, por

confederações ou coalizões de grupamentos políticos estaduais ou locais, que podem se compor de forma distinta em cada eleição e na formação do 'partido parlamentar', isto é, da bancada efetiva de cada partido; $6^{\circ}$. ainda como conseqüência das proposições dos dois itens anteriores, os partidos freqüentemente atuam de quatro formas diferentes: como 'partidos eleitorais', estruturados em função da lógica específica e dos interesses envolvidos em cada eleição; como 'partidos parlamentares', dominados pelas bancadas no Legislativo; como 'partidos locais' ou 'estaduais' transformados em instrumento de pressão no relacionamento entre os diversos níveis de Governo e na defesa de políticas de interesse local ou regional; como 'partidos federais' dominados por suas principais e mais poderosas lideranças, em geral instaladas nas executivas nacionais, mas que tem sua ação sempre condicionada pela representação do 'partido parlamentar' e pelas pressões dos 'partidos locais'; $7^{\circ}$. o presidencialismo brasileiro, ao organizar-se, por diversas razões, como um 'presidencialismo de coalizão', que praticamente obriga o Presidente a organizar seu Governo com base em ampla composição de forças partidárias e regionais, sustenta-se em delicado equilíbrio, derivado das contradições existentes: a) entre a resultante nacional da correlação de forças político-partidárias e aquelas que estruturam os sistemas políticos locais, que ocorrem dentro de praticamente todos os partidos brasileiros; b) entre os diferentes partidos na coalizão, os quais, na melhor das hipóteses, comportam-se quase sempre como 'aliados à distância e adversários muito próximos' e c) entre a coalizão governamental e a correlação de forças no Congresso, oriundas de movimentos eleitorais e configuração de interesses freqüentemente muito distintas; $8^{\circ}$. a instável e complexa composição do Executivo, que procura representar, da melhor forma possível, cada um desses diferentes eixos da dinâmica política brasileira, é fonte permanente de tensões e conflitos no processo decisório nacional, que se refletem, com freqüência, nas relações entre Executivo e Legislativo e entre o Governo Federal e os Governos Estaduais; $9^{\circ}$. esse arranjo institucional aumenta consideravelmente os riscos de sérios conflitos entre Legislativo e Executivo, paralisia decisória e ingovernabilidade e instabilidade institucional".

330 Federalismo. In: AVELAR, Lúcia; CINTRA, Antônio Octávio (org.). Sistema político brasileiro: uma introdução. $2^{a}$ ed. Rio de Janeiro: Konrad-Adenauer-Stiftung; São Paulo: Editora UNESP, 2007, p. 218.

331 A democracia brasileira vai bem, mas requer cuidados: proposições sobre democracia brasileira e o presidencialismo de coalizão. Estudos e pesquisas $n^{\circ}$ 5, XIII Fórum Nacional, Rio de Janeiro, maio 2001, INAE - Instituto Nacional de Altos Estudos, p. 16. Disponível em www.forumnacional.org.br/trf_arq.php?cod=EP00050, acessado em 30.11.2009. 
apoio político", mas, também, "cria estímulos a práticas corruptas, ilegais, que se confundem com clientelismo, nepotismo e outras variações de patrimonialismo, muitas já incorporadas à estrutura legal do país" ${ }^{332}$.

Exemplo disso, aliás, foi o surgimento de denúncias referentes ao "esquema de compra de votos de parlamentares”, ocorrido em 2005, durante o governo do Presidente Luiz Inácio Lula da Silva. Alegou-se que deputados eram instados a votarem projetos de interesse do Poder Executivo federal, mediante o pagamento mensal de propina; daí o esquema também receber a denominação de "escândalo do mensalão". O principal executor do arranjo seria o dono de agências de publicidade (SMP\&B e DNA), Marcos Valério de Souza, o qual possuía, à época, contratos com órgãos públicos.

De acordo com a denúncia apresentada pelo Ministério Público Federal, objeto do Inquérito 2.245-4 (MG), em trâmite no Supremo Tribunal Federal, integrantes do Partido dos

332 Críticas ao Presidencialismo de Coalizão no Brasil: Processos Institucionalmente Constritos ou Individualmente Dirigidos? In: AVRITZER, Leonardo; ANASTASIA, Fátima (org.). Reforma política no Brasil. Belo Horizonte: Editora UFMG, 2006, p. 269. Sérgio Hudson de Abranches (A democracia brasileira vai bem, mas requer cuidados: proposições sobre democracia brasileira e o presidencialismo de coalizão. Estudos e pesquisas n ${ }^{\circ}$ 5, XIII Fórum Nacional, Rio de Janeiro, maio 2001, INAE - Instituto Nacional de Altos Estudos, pp. 4-5, 11 e 14. Disponível em www.forumnacional.org.br/trf_arq.php?cod=EP00050, acessado em 30.11.2009), por sua vez, entende que o clientelismo não é provocado, propriamente, pelo sistema do "presidencialismo de coalizão", mas tem como origem momento anterior, decorrente da relação entre parcela do eleitorado e grupos partidários. Explica o autor:

"Nossa democracia tem déficits decorrentes de sua infância e das descontinuidades que duas décadas de ditadura militar produziram. No recrutamento político, por exemplo. A formação de várias gerações políticas foi deformada, interrompida ou desviada pela repressão e pela polarização que a tirania inevitavelmente cria. Na estruturação de nossa cultura cívica, entrecortada por valores categóricos, setoriais, regionais, faccionais. Na eficácia dos governos, sobretudo em virtude de nosso padrão de governança, o presidencialismo de coalizão que não tem vícios intrínsecos que o condenam, como alguns imaginam, mas cria propensões clientelísticas se e quando há predomínio de agrupamentos clientelistas na formação da maioria. Mas o clientelismo não é uma decorrência da governança, como argumentarei mais adiante, resulta da existência de nexos de clientela na relação real e dominante entre parcelas do eleitorado e determinadas facções partidárias. O que acaba com o clientelismo não é reforma formal, é mudança nos padrões de demanda e oferta na relação política nas comunidades. [...]

Nosso sistema eleitoral tem falhas evidentes no financiamento de campanhas, na extensa faixa de persistência de relações clientelísticas e de patronagem na obtenção e manutenção do voto. Problema que se estende ao comportamento do legislativo e às relações entre Executivo e Legislativo (...) que são a contrapartida da sobrevivência dessas formas oligárquicas de dominação política em vários subsistemas políticos no país. [...]

O outro pecado capital que tem sido atribuído a esse regime de governança no Brasil, recentemente, é que ele teria embutido incentivos irresistíveis ao fisiologismo e ao clientelismo. A gestão da coalizão se basearia em um toma-lá-dá-cá, que feriria os princípios da ética na política. E há uma série de exemplos recentes desse 'varejão' para supostamente provar essa tese. Não creio que o fisiologismo e o clientelismo sejam intrínsecos ao regime de governança. Eles são componentes do padrão de relacionamento entre partidos e eleitores, portanto um dado sociológico. Se os partidos majoritários logram conquistar essa maioria por meio desse tipo de mecanismo de manipulação do eleitor despossuído e não há alternativas competitivas em muitos redutos, a relação entre essa maioria legislativa e o Executivo terá, de fato, um elevado grau de propensão ao fisiologismo e ao clientelismo. Mas seria assim, se o governo não fosse de coalizão". 
Trabalhadores (PT), com o intuito de assegurarem a continuidade do projeto político, teriam estruturado um esquema de desvio de recursos de órgãos públicos e de empresas estatais, com a finalidade de utilizar tais valores na obtenção de apoio político de outros partidos e no financiamento de campanhas eleitorais, futuras e pretéritas.

Para a viabilização do arranjo teria ocorrido a participação de empresas, dentre elas a de Marcos Valério de Souza, as quais tinham como finalidade repassar recursos financeiros (em dinheiro, na maioria das vezes) aos parlamentares e agentes públicos. A contrapartida às empresas seriam comissões de intermediação em contratos públicos e outras vantagens de natureza pecuniária, introduzidas em contratos de publicidade realizados com órgãos e entidades governamentais ou, ainda, com destinatárias de recursos governamentais.

Constam na denúncia relatos de fatos caracterizados como de corrupção ativa e passiva, peculato, fraude, lavagem de dinheiro e formação de quadrilha. A denúncia foi recebida mediante Sessão Plenária do Supremo Tribunal Federal ocorrida em 28/08/2007, em que foi relator o Ministro Joaquim Barbosa ${ }^{333}$. A ação penal está em trâmite no mesmo tribunal (sob o número 470), em que serão julgados os quarenta denunciados pelo Procurador Geral da República ${ }^{334}$.

O mencionado esquema teria como origem um outro, denominado "mensalão tucano" ou "mensalão mineiro", ocorrido em 1998 durante a campanha para a eleição de Eduardo Azeredo ao governo de Minas Gerais e de seu vice, Clésio Andrade. O sistema consistiria no financiamento irregular à campanha da re-eleição para o governo estadual, por intermédio de recursos públicos e doações privadas ilegais, estruturação essa que também teria sido executada por Marcos Valério de Souza.

Os termos da denúncia, apresentada ao Supremo Tribunal Federal em 22/11/2007, nos autos do Inquérito $\mathrm{n}^{\circ} 2280(\mathrm{MG})^{335}$, indicam que o esquema "foi a origem e o laboratório" dos mesmos fatos anteriormente descritos (caso do "mensalão"). Ainda de acordo com a denúncia, a essência do esquema consistiria no desvio direto de recursos do Estado de Minas Gerais ou, indiretamente, por intermédio de suas estatais (a Companhia de Saneamento de Minas Gerais - Copasa; a Companhia Mineradora de Minas Gerais - Comig; e o Grupo Financeiro do Banco do Estado de Minas Gerais - Bemge), em benefício pessoal dos candidatos a governador e vice. De outro lado, empresas privadas (empreiteiras) teriam

333 O acórdão foi publicado em 09.11.2007.

334 O Ministro Joaquim Barbosa também é o relator da ação penal.

335 O relator do inquérito é o Ministro Joaquim Barbosa. 
doado, sem declaração à Justiça Eleitoral, altos valores para a campanha de Eduardo Azeredo, empresas essas que também teriam recebido pagamentos vultosos por obras na gestão do governador. A empresa de Marcos Valério (SMP\&B), com a participação do Banco Rural, teria adotado práticas de lavagem de dinheiro com o fim de transformar os recursos públicos desviados em valores aparentemente lícitos, utilizados na campanha. A denúncia do Ministério Público Federal indica fatos que consistiriam crime de peculato e de lavagem de dinheiro; foi recebida pelo Supremo Tribunal Federal em 03/12/2009.

Mais recentemente, outro fato surgiu nos noticiários, dando origem ao escândalo do “mensalão do DEM", expressão dada em referência à sigla do Partido dos Democratas. A situação demonstra como a necessidade de coalizão, também no âmbito dos governos estaduais, é favorável ao surgimento de práticas corruptas.

$\mathrm{O}$ inquérito do caso (recebido como $\mathrm{n}^{\circ} 650^{336}$ ) tramita em segredo de justiça no Superior Tribunal de Justiça, sob a relatoria do Ministro Fernando Gonçalves. Apura-se se o atual Governador do Distrito Federal, José Roberto Arruda, seria o responsável por repassar pagamentos mensais a deputados da base aliada, no âmbito da Câmara Legislativa, em troca de apoio político ${ }^{337}$.

Os recursos teriam como origem pagamentos realizados por empresas de informática (Vertax, Linknet, Infoeducacional e Adler), que possuíam contratos com o governo do Distrito Federal $^{338}$. Tais recursos seriam utilizados no financiamento de campanhas eleitorais, em 2006, e no pagamento a deputados da base aliada; parcela dos valores também seria destinada ao próprio governador e a assessores ${ }^{339}$.

Fácil perceber que, tanto no âmbito federal quanto no estadual, a estrutura de governo por coalizão, da forma como praticada no Brasil, favorece atos de desvio de recursos públicos.

${ }^{336}$ O inquérito é fruto da "Operação Caixa de Pandora", da Polícia Federal.

337 Também estariam envolvidos no esquema o ex-chefe da Casa Civil do Distrito Federal, o assessor de imprensa do governador, seu ex-chefe de gabinete, o presidente da Câmara Legislativa e alguns deputados distritais.

338 Aliás, segundo as apurações, desde 2004, para obtenção de vantagens na administração do exgovernador Joaquim Roriz e, depois, na de José Roberto Arruda, as empresas fornecedoras do governo do Distrito Federal já pagariam propina.

339 "PF diz que Arruda mandou dar R \$ 400 mil a deputados". Folha de São Paulo, 28/11/2009, p. A-4; "Em vídeo, governador do DF recebe pacote de dinheiro". Folha de São Paulo, 29/11/2009, p. A-4; "Em vídeo, aliado de Arruda guarda dinheiro nas meias". Folha de São Paulo, 30/11/2009, p. A-4; "Esquema começou na campanha e deu origem a "mensalão". Folha de São Paulo, 30/11/2009, p. A-7. 
$\mathrm{Na}$ verdade, as afirmações acima ratificam o entendimento de que, no Brasil, "o federalismo como mecanismo de divisão territorial de poder é mais uma forma de acomodar conflitos regionais do que de promover harmonia" e que, também, "é mais uma ideologia baseada em valores e interesses do que um compromisso baseado em arranjos legais e territoriais ou em propósitos democráticos"340.

De fato, depreende-se que a atual Constituição optou por entregar maior carga de poder aos estados mais pobres em vez de buscar a equalização da federação por intermédio da descentralização fiscal efetiva. Essa particularidade, aliada à incapacidade de o governo central estabelecer a coordenação e o equilíbrio da federação, favorece o desvio de recursos públicos, pois o poder político concedido aos mencionados estados pode ser utilizado para manter o domínio eleitoral em seus respectivos territórios ou para outros fins divorciados do interesse público.

O poder concedido aos estados menores serve como instrumento de barganha para se atingir interesses pessoais e eleitorais de seus governantes. Impede-se, assim, a cooperação entre os entes subnacionais e a viabilização de um projeto nacional para o país.

Repensar o federalismo fiscal brasileiro pressupõe, dessa forma, reavaliar não somente a forma de descentralização fiscal, mas também suas outras dimensões, tais como a descentralização política e a descentralização de políticas, transmitindo-se ao governo central o poder de, efetivamente, coordenar, planejar e implementar projetos nacionais para o país, com a cooperação real dos entes federados. Por intermédio dessas transformações, buscar-seá, na verdade, a viabilização da implementação eficaz das funções fiscais alocativa, distributiva e estabilizadora. Referidos ajustes também devem contemplar alterações necessárias nos sistemas eleitoral e político brasileiros, como forma de evitar incentivos maiores à prática de desvios de recursos públicos.

340 SOUZA, Celina. Redemocratização, federalismo e gasto social no Brasil: tendências recentes. Petrópolis (RJ), 23-27 out. 1999, XXIV Encontro Anual da Associação Nacional de Pós-graduação em Ciências Sociais (ANPOCS), $\quad$ p. $\quad 21 . \quad$ Disponível http://info.worldbank.org/etools/docs/library/232522/SouzaRedemocratizacao.pdf, acessado em 26.11.2009. 


\subsubsection{O importante papel das instituições no federalismo fiscal brasileiro e a questão da} accountability e do controle

Se é verdade que a descentralização, na forma e nas dimensões já mencionadas, é importante e essencial para promover mecanismos eficientes de prevenção à corrupção e ao desvio de recursos, não menos verdade é que isso somente poderá ser viabilizado mediante o fortalecimento das instituições do país.

O termo instituição vem do latim institutio, derivado de instituere, que significa estabelecer, fundar, nomear, designar. Possui diversos sentidos, mas na sociologia é designada como um complexo de normas que controlam a ação social ou, em termos mais genéricos, seria a conduta praticada reiteradamente no âmbito de um grupo social ${ }^{341}$.

A primeira definição é a que será empregada no presente estudo, de forma que se entenderá como instituição o "conjunto de regras estabelecidas quer pelo legislador, quer pelos particulares, em vista da satisfação de interesses coletivos ou privados", podendo se apresentar "sob a forma de uma pessoa moral de direito público (ex.: Estado, Parlamento), ou de direito privado (ex.: associação), ou de um agrupamento não personalizado, ou de uma fundação, ou de um certo regime, como o da tutela, o da prescrição, o da falência"342.

De acordo com Luiz Fernando Coelho, "não basta, para caracterizar a instituição, a objetivação de uma idéia incorporando pessoas em torno de si, mas é preciso que essa idéia se concentre no valor mais alto: o bem comum" ${ }^{343}$. É por esse motivo que Alain Birou considera a instituição "uma estrutura parcial da sociedade, diferente do grupo, e desempenhando uma função específica da vida social. Possui certas normas que tendem a ser obrigatórias e que lhe são reconhecidas ou impostas pela sociedade global", acrescentando, ainda, que ela "realiza ao longo de várias gerações objectivos explícitos que a tornam conhecida e aceite por toda a sociedade; as normas, os objectivos que se pretendem, os

341 Nicola Abbagnano. Dicionário de filosofia. Tradução de Alfredo Bosi e Ivone Castilho Benedetti. $5^{\mathrm{a}}$ ed. São Paulo: Martins Fontes, 2007, p. 654. Título original: Dizionario di Filosofia.

342 FILHO, João de Oliveira. In: SANTOS, J. M. de Carvalho. Repertório enciclopédico do direito brasileiro. Rio de Janeiro: Editor Borsoi, v. 27, p. 241. A definição de Max Weber (Economia $e$ sociedade: fundamentos da sociologia compreensiva. Tradução de Regis Barbosa e Karen Elsabe Barbosa. $4^{a}$ ed. Brasília - São Paulo: Editora Universidade de Brasília - Imprensa Oficial do Estado de São Paulo, 1999, v. 1, p. 32. Título original: Wirtschaft und Gesellschaft: Grundriss der verstehenden Soziologie) é igualmente relevante para demonstrar o sentido do termo, empregado no presente estudo: "Denominamos instituição uma associação cuja ordem estatuída se impõe, com (relativa) eficácia, a toda ação com determinadas características que tenha lugar dentro de determinado âmbito de vigência".

343 In: FRANÇA, R. Limongi (coord.). Enciclopédia Saraiva do Direito. São Paulo: Saraiva, 1980, v. 44, p. 516. 
valores escolhidos, constituem um sistema que pode evoluir, mas que mantém unidade e coerência" 344 .

Diante do que foi acima mencionado torna-se possível afirmar a existência de uma diversidade de instituições, tais como as de ordem política, econômica, democrática etc. ${ }^{345}$.

De acordo com Paulo Bonavides, a Constituição brasileira exerce a proteção a algumas instituições de basilar importância à sociedade, assim como a direitos fundamentais que encontram em seu âmago algum elemento institucional. Daí se afirmar que aquelas garantias constitucionais em cuja substância não há um caráter subjetivo individualista, mas um conteúdo referente à atuação das instituições ou órgãos do poder público, são, na verdade, garantias institucionais ${ }^{346}$.

As garantias institucionais variam de Estado para Estado, de acordo com a importância que cada um deles dá a determinada instituição no âmbito das respectivas Constituições. O sentido de tais garantias é o de justamente impedir a extinção das instituições, assegurando-lhes o "mínimo essencial”, proteção essa também viabilizada por

344 Dicionário das ciências sociais. Tradução de Alexandre Gaspar, Isabel Madureira Pinto, Linda Xavier e Maria Manuela Meneses. 3 ${ }^{a}$ ed. Lisboa: Publicações Dom Quixote, 1977, p. 209. Título Original: Vocabulaire Pratique des Sciences Sociales.

345 Conforme já afirmado, as instituições podem ser tanto de direito público (Estado, organização da Justiça, sistema eleitoral etc.), como de direito privado (família, propriedade, associações etc.) ou, ainda, não possuírem personalidade, mas apenas serem objeto de um organismo ou de um determinado regime. Quanto a esse ponto, importantes as considerações de Luiz Fernando Coelho (In: FRANÇA, R. Limongi (coord.). Enciclopédia Saraiva do Direito. São Paulo: Saraiva, 1980, v. 44, pp. 511-512) quando analisa o conceito jurídico de instituição:

"O conceito jurídico de instituição, na verdade, tanto dimana de uma cosmovisão exclusivamente normativista quanto de uma visão sociológica, pois enfatiza a existência de comportamentos uniformes dos membros de uma coletividade, em função de uma gênese e objetivos comuns, mas conceptualizados normativamente, de modo a configurar uma organização social definida por normas jurídicas; destarte, a propriedade é uma instituição, na medida em que, sob este termo, se compreende a somatória de condutas uniformes dos membros do corpo social, em relação às coisas a que atribuem valor econômico; e é uma instituição jurídica, pois tal comportamento é definido em suas linhas básicas por expressões normativas de natureza jurídica. Do mesmo modo, a família, o Estado, os sindicatos, as empresas são instituições, caracterizadas pelo comportamento grupal uniforme e definição legal ou consuetudinária.

A palavra instituição é, pois, empregada na linguagem jurídica com esse significado bastante amplo, aludindo a quaisquer organizações sociais de caráter jurídico, com personalidade jurídica ou não. Mas, a rigor, a palavra só se aplica às organizações que, produto da evolução do povo, são por ele efetivamente acatadas, pois que correspondem às suas aspirações e à sua índole, e, por isso, tendem a permanecer, a despeito das modificações por que passam as normas jurídicas que as definem".

346 Curso de direito constitucional. $15^{\text {a }}$ ed. atual. São Paulo: Malheiros, 2004, pp. 534-538. As garantias institucionais surgem com o advento do Estado Social do século XX. Tais garantias referem-se a instituições de direito público, mas abarcam, também, aquelas garantias que protegem institutos de direito privado, tais como o direito à educação, à maternidade etc. $\mathrm{O}$ autor considera que as garantias constitucionais abrangem não apenas os direitos fundamentais de âmbito individual, como também as instituições presentes no Estado. Sobre esse aspecto, aliás, Paulo Bonavides conclui que "a garantia constitucional é uma garantia que disciplina e tutela o exercício dos direitos fundamentais, ao mesmo passo que rege, com proteção adequada, nos limites da Constituição, o funcionamento de todas as instituições existentes no Estado" (Op. cit., p. 537). 
intermédio de "pressões sociais ou de imperativos da consciência pública, empenhada e inclinada em promover a igualdade, como o primeiro dos postulados de um Estado"347.

No caso do Brasil, ganha importância a discussão sobre as instituições políticas, principalmente no que diz respeito ao sistema eleitoral, ao grau de dependência entre o Poder Executivo e o Poder Legislativo, à questão da pluralidade de partidos e ao presidencialismo. Alguns desses aspectos já foram abordados no item antecedente, mas o que resta averiguar é por que motivo o tratamento dessas instituições e de outras importantes à democracia mostra-se importante para o combate ao desvio de recursos.

A resposta a essa questão está diretamente ligada à accountability, que diz respeito à responsabilização da autoridade pela administração dos recursos públicos e ao seu dever de prestar contas à população ${ }^{348}$. É por seu intermédio que se "propicia a operacionalização de sistemas de cobrança, fiscalização e punição" ${ }^{349}$.

O fortalecimento das instituições, principalmente as de âmbito político, tem como principal consequência viabilizar uma eficiente accountability, de forma a permitir que os cidadãos consigam melhor perceber o que ocorre no país, fiscalizem os atos praticados pelos órgãos governamentais, bem como passem a deles exigir determinados comportamentos em proveito do bem comum. É por esse motivo que a maneira como certa instituição se estrutura é que irá ditar se os fins a que ela se destina serão alcançados de forma eficaz ou não ${ }^{350}$.

Se a força das instituições é importante para manter um bom nível de accountability, permitindo uma eficiente governança ${ }^{351}$, importante que qualquer nível de descentralização

347 Paulo Bonavides. Curso de direito constitucional. 15 a ed. atual. São Paulo: Malheiros, 2004, pp. 541542.

348 Como afirmado em momento anterior, neste trabalho, Ricardo Lobos Torres (Tratado de direito constitucional financeiro e tributário: o orçamento na Constituição. $2^{\mathrm{a}}$ ed., rev. e atual. Rio de Janeiro: Renovar, 2000, v. 5, p. 308) define accountability como "a responsabilidade pela eficiente gerência de recursos públicos".

349 Marcos Fernandes Gonçalves da Silva. A economia política da corrupção no Brasil. São Paulo: Editora SENAC São Paulo, 2001, p. 133.

350 Nesse sentido, Antônio Octávio Cintra (Presidencialismo e parlamentarismo: são importantes as instituições? In: AVELAR, Lúcia; CINTRA, Antônio Octávio (org.). Sistema político brasileiro: uma introdução. $2^{a}$ ed. Rio de Janeiro: Konrad-Adenauer-Stiftung; São Paulo: Editora Unesp, 2007, p. 36) lembra a importância de uma boa estruturação das instituições políticas: "Para a moderna Ciência Política, as instituições permitem às pessoas e grupos cooperar, regular e permanentemente e, de modo confiável, em empreendimentos comuns, necessários à vida em sociedade. As instituições estimulam certos comportamentos dos eleitores e dos próprios políticos e partidos, e desencorajam outros. Se os homens se organizam politicamente para lograr fins não alcançáveis fora da política, os comportamentos induzidos pelos sistemas de governo e pelo sistema eleitoral vão facilitar-lhes a tarefa ou torná-la mais espinhosa".

351 De acordo com Marcos Fernandes Gonçalves da Silva (A economia política da corrupção no Brasil. São Paulo: SENAC São Paulo, 2001, p. 134), a governança diz respeito à "capacidade financeira, gerencial/administrativa e política que permite a uma organização pública ou privada executar com eficácia suas atribuições, missão e objetivos". 
que se estabeleça esteja também calcado na consolidação das mesmas instituições. De fato, de nada adianta transferir maiores responsabilidades aos entes subnacionais se não houver um claro e efetivo robustecimento de suas instituições, sob o risco de apenas se proceder à transferência dos problemas do âmbito do poder central para a esfera periférica dos governos locais e regionais.

Aliás, o advento da descentralização, sem o necessário reforço das instituições, pode até dificultar ainda mais a accountability (em comparação ao que seria realizado numa maior presença do governo central). Nessa hipótese, estar-se-ia proporcionando maiores incentivos ao desvio de recursos públicos, especialmente quando instituições frágeis ficam ao alvedrio das elites locais, fato esse muito comum no Brasil, principalmente nas regiões Norte e Nordeste.

A descentralização deve, assim, ser guarnecida com a mudança do arcabouço de poder no âmbito das comunidades, concedendo-se a elas maior autoridade de decisão e participação. Não se estaria, com isso, enfraquecendo o poder central, mas entregando aos poderes locais condições para perceber as necessidades da população ${ }^{352}$. Isso somente é possível, no entanto, por intermédio de instituições bem estruturadas.

A importância das instituições como elemento de combate e prevenção à corrupção é bem explicitada por Robin Boadway e Anwar Shah ${ }^{353}$ :

Em sociedades nas quais o nível de corrupção no setor público é relativamente fraco, normalmente encontram-se poderosas instituições de participação e accountability que controlam os abusos de poder praticados por funcionários públicos. Essas instituições são criadas pelo próprio Estado (p. ex., processo eleitoral, Carta dos Cidadãos, Declaração de Direitos, auditores-gerais, o Judiciário, o Legislativo) ou aparecem fora de estruturas estatais

352 Pranab Bardhan. Decentralization of Governance and Development. In: The Journal of Economic Perspectives, v. 16, n. 4, outono 2002, American Economic Association, p. 202. Disponível em http://www.jstor.org/stable/3216920, acessado em 04.12.2009. No original: "This means that decentralization, to be really effective, has to accompany serious attempts to change the existing structures of power within communities and to improve the opportunities for participation and voice and engaging the hitherto disadvantaged or disenfranchised in the political process. After all, the logic behind decentralization is not just about weakening the central authority, nor is it about preferring local elites to central authority, but it is fundamentally about making governance at the local level more responsive to the felt needs of the large majority of the population".

353 Fiscal Federalism: Principles and Practices of Multiorder Governance. New York: Cambridge University Press, 2009, p. 528 (tradução livre do autor). No original: "In societies where the level of public-sector corruption is relatively low, one normally finds strong institution of participation and accountability that control abuses of power by public officials. These institutions are either created by the state itself (e.g., electoral process, citizens' charter, bill of rights, auditors-general, the judiciary, the legislature) or arise outside of formal state structures (e.g., the news media and organized civil groups). There are glaring weaknesses in institutions of participation and accountability in highly corrupt countries". 
formais (p. ex., mídia e grupos civis organizados). Há fraquezas evidentes nas instituições de participação e accountability localizadas em países altamente corruptos.

Dados relevantes para averiguar a qualidade das instituições no Brasil podem ser encontrados no Relatório Global de Integridade, elaborado pela organização não governamental (ONG) Global Integrity, sediada em Washington, nos Estados Unidos. O relatório indica como atuam e se organizam as instituições do país no combate à corrupção. O último documento em que se estudou o caso brasileiro foi elaborado em 2006 e apresenta resultados individualizados para cada instituição analisada, com adoção de níveis de avaliação (muito fraco, fraco, moderado, forte e muito forte), com a finalidade de averiguar o grau de fragilidade ou estabilidade da respectiva instituição ${ }^{354}$.

A pesquisa é dividida em seis grandes categorias: a) sociedade civil, informação pública e mídia; b) eleições; c) responsabilização do governo (government accountability); d) burocracia e serviço público; e) supervisão e regulação; f) legislação anti-corrupção.

No tocante à primeira categoria (sociedade civil, informação pública e mídia), o Brasil foi avaliado no nível fraco. Constatou-se que, dentre as organizações da sociedade civil brasileiras, poucas se voltam à questão da corrupção, mas, mesmo assim, as que cuidam da questão possuem liberdade em suas atividades, não sofrendo interferências para o seu exercício. A mídia obteve uma avaliação fraca, uma vez que se identificou que os meios de comunicação recebem interferências das oligarquias locais e regionais, não conseguindo atuar com a independência necessária; no plano nacional, contudo, raras são essas intervenções. Quanto ao acesso público à informação, verificou-se que não há lei específica regulamentando-o, embora existam leis esparsas que garantam esse acesso (alguns dispositivos da Lei de Licitações ${ }^{355}$, por exemplo, que permitem acesso às informações contidas em processo licitatório); muitas vezes são encontradas restrições para o recebimento de informações de órgãos públicos, além de o processo de sua obtenção ser lento e custoso.

$\mathrm{Na}$ segunda categoria, referente às eleições, foi apurado um nível forte das instituições. Esse resultado foi fruto de uma avaliação muito forte em relação à votação no Brasil, à participação dos cidadãos no processo de votação e no processo político, bem como à integridade das eleições, inclusive no tocante à sua transparência. A avaliação para o

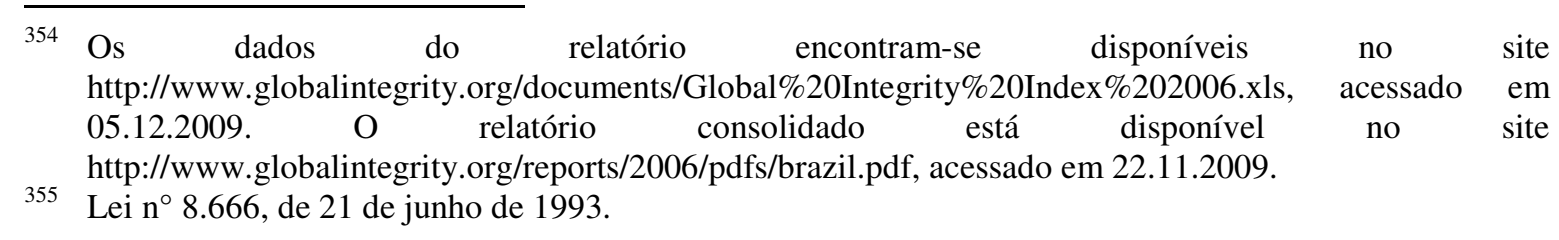


financiamento político, contudo, foi muito fraca devido a alguns fatores: i) o Brasil possui legislação disciplinando o financiamento político (Lei $\mathrm{n}^{\circ}$ 9.096, de 19 de setembro de 1995, que dispõe sobre os partidos políticos, e Lei $\mathrm{n}^{\circ}$ 9.504, de 30 de setembro de 1997, que estabelece normas para as eleições), mas não existem limites para as despesas dos partidos políticos e nem mecanismos para uma auditoria eficiente das finanças desses partidos e dos candidatos; ii) na prática, as contribuições para os candidatos e partidos políticos não são auditadas; iii) o acesso aos registros relacionados ao financiamento político não está inteiramente disponível à população, uma vez que, embora as informações sobre o apoio financeiro aos candidatos estejam presentes na rede mundial de computadores (internet), as finanças dos partidos políticos não possuem a mesma transparência, sendo na maioria das vezes publicadas apenas no Diário Oficial.

A terceira categoria, referente à responsabilização do governo, recebeu avaliação moderada em razão do fraco desempenho da accountability do Poder Judiciário e do processo orçamentário. Já os Poderes Executivo e Legislativo, quanto ao mesmo critério, obtiveram avaliação moderada. Particularmente em relação ao processo orçamentário, o fraco desempenho foi resultado da ausência de alguns fatores: transparência na aprovação final do orçamento; contribuição dos cidadãos nas audiências do orçamento; atuação apartidária das comissões legislativas; proteção das comissões legislativas contra interferências políticas; autonomia das comissões legislativas para investigar sistematicamente eventuais irregularidades financeiras. No tocante ao Poder Judiciário, entendeu-se que o Conselho Nacional de Justiça (CNJ), embora não opere exatamente como um ombudsman - pois formado por profissionais relacionados ao Poder Judiciário (juízes, advogados etc.) e comandado pelo presidente do Supremo Tribunal Federal -, possui proteção contra interferências políticas, disciplina aspectos relevantes do judiciário brasileiro e está obtendo bons resultados no combate ao nepotismo. Apesar dessas vantagens, o CNJ ainda não possui amplo poder para iniciar investigações e impor penalidades. A forma de nomeação de membros do Supremo Tribunal Federal também é criticada no relatório: embora a indicação seja do Presidente da República (sujeita à aprovação do Senado Federal) e apesar de a qualidade dos nomeados ser, em geral, muito boa, a forma como tal indicação ocorre é fruto de muitas críticas. Em relação ao Poder Executivo, as fragilidades apontadas referem-se: i) à utilização frequente de medidas provisórias (artigo 62, da Constituição 
Federal $^{356}$ ); ii) à ineficácia de regulamentos que restringem a atuação, no setor privado, de ex-ministros e chefes de governo; iii) à livre nomeação, pelo Executivo, de cerca de 23.000 pessoas para o preenchimento de cargos na Administração e empresas estatais ${ }^{357}$, nomeação essa utilizada de forma política, com a finalidade de preencher quadros do partido do governo e com o objetivo de negociar apoio de outros parlamentares; a situação nos estados é a mesma. Quanto ao Poder Legislativo, algumas deficiências também foram relacionadas, tais como a inexistência de legislação disciplinando restrições ao ingresso de parlamentares no setor privado, após o fim do mandato, bem como a ausência de lei disciplinando recebimento de presentes ou oferecimento de hospitalidade aos membros do legislativo.

Em referência à burocracia e ao serviço público, quarta categoria do relatório, verificou-se um desempenho fraco. Enquanto os processos de licitação e de privatização ${ }^{358}$ foram considerados muito fortes, os regulamentos do serviço público e os procedimentos de

356 Constituição Federal: “Art. 62. Em caso de relevância e urgência, o Presidente da República poderá adotar medidas provisórias, com força de lei, devendo submetê-las de imediato ao Congresso Nacional. $\S$ $1^{\circ}$ É vedada a edição de medidas provisórias sobre matéria: I - relativa a: a) nacionalidade, cidadania, direitos políticos, partidos políticos e direito eleitoral; b) direito penal, processual penal e processual civil; c) organização do Poder Judiciário e do Ministério Público, a carreira e a garantia de seus membros; d) planos plurianuais, diretrizes orçamentárias, orçamento e créditos adicionais e suplementares, ressalvado o previsto no art. $167, \S 3^{\circ}$; II - que vise a detenção ou seqüestro de bens, de poupança popular ou qualquer outro ativo financeiro; III - reservada a lei complementar; IV - já disciplinada em projeto de lei aprovado pelo Congresso Nacional e pendente de sanção ou veto do Presidente da República. $\S 2^{\circ}$ Medida provisória que implique instituição ou majoração de impostos, exceto os previstos nos arts. 153, I, II, IV, V, e 154, II, só produzirá efeitos no exercício financeiro seguinte se houver sido convertida em lei até o último dia daquele em que foi editada. $\S 3^{\circ}$ As medidas provisórias, ressalvado o disposto nos $\S \S 11$ e 12 perderão eficácia, desde a edição, se não forem convertidas em lei no prazo de sessenta dias, prorrogável, nos termos do $\S 7^{\circ}$, uma vez por igual período, devendo o Congresso Nacional disciplinar, por decreto legislativo, as relações jurídicas delas decorrentes. $\S 4^{\circ} \mathrm{O}$ prazo a que se refere o $\S 3^{\circ}$ contar-se-á da publicação da medida provisória, suspendendo-se durante os períodos de recesso do Congresso Nacional. $\S 5^{\circ}$ A deliberação de cada uma das Casas do Congresso Nacional sobre o mérito das medidas provisórias dependerá de juízo prévio sobre o atendimento de seus pressupostos constitucionais. $\S 6^{\circ} \mathrm{Se}$ a medida provisória não for apreciada em até quarenta e cinco dias contados de sua publicação, entrará em regime de urgência, subsequientemente, em cada uma das Casas do Congresso Nacional, ficando sobrestadas, até que se ultime a votação, todas as demais deliberações legislativas da Casa em que estiver tramitando. $\S 7^{\circ}$ Prorrogar-se-á uma única vez por igual período a vigência de medida provisória que, no prazo de sessenta dias, contado de sua publicação, não tiver a sua votação encerrada nas duas Casas do Congresso Nacional. § $8^{\circ}$ As medidas provisórias terão sua votação iniciada na Câmara dos Deputados. § $9^{\circ}$ Caberá à comissão mista de Deputados e Senadores examinar as medidas provisórias e sobre elas emitir parecer, antes de serem apreciadas, em sessão separada, pelo plenário de cada uma das Casas do Congresso Nacional. § 10. É vedada a reedição, na mesma sessão legislativa, de medida provisória que tenha sido rejeitada ou que tenha perdido sua eficácia por decurso de prazo. $§ 11$. Não editado o decreto legislativo a que se refere o $\S 3^{\circ}$ até sessenta dias após a rejeição ou perda de eficácia de medida provisória, as relações jurídicas constituídas e decorrentes de atos praticados durante sua vigência conservar-se-ão por ela regidas. $§ 12$. Aprovado projeto de lei de conversão alterando o texto original da medida provisória, esta manter-se-á integralmente em vigor até que seja sancionado ou vetado o projeto".

357 Dados de 2006

358 O termo "privatização" é considerado no relatório em sentido amplo, ou seja, abarcando não somente a ideia da mudança de controle das empresas estatais para o setor privado, mas também as concessões, as terceirizações e as demais formas de parcerias público-privadas. 
denúncia (contra corrupção, suborno, abuso de poder ou abuso de recursos) tiveram uma avaliação muito fraca. No tocante às regras do serviço público, identificou-se que embora a própria Constituição brasileira e a Lei $\mathrm{n}^{\circ}$ 8.112, de 11 de dezembro de 1990 - que dispõe sobre o regime jurídico dos servidores públicos civis da União, das autarquias e das fundações públicas federais - forneçam elementos para viabilizar um imparcial, independente e bem administrado serviço público, existem fatores que impedem que isso se realize. Um desses fatores diz respeito à nomeação, por critérios exclusivamente políticos, de pessoas em cargos de comissão, o que poderia caracterizar-se numa fonte de corrupção na medida em que tais nomeações fossem utilizadas para possibilitar coalizões legislativas ou fossem fruto do nepotismo, camaradagem ou patronagem.

A quinta categoria, relativa à supervisão e regulação, obteve um desempenho moderado. As avaliações das instituições referentes a essa classe foram as seguintes:

i) Ombudsman Nacional: muito fraco. Identificou-se que, no Brasil, esse papel é exercido pela Controladoria-Geral da União (conforme Lei $\mathrm{n}^{\circ} 10.683$, de 28 de maio de 2003), por intermédio da Ouvidoria-Geral da União ${ }^{359}$. Ocorre que tal órgão não é independente daquele que configura objeto de sua fiscalização, ou seja, a própria União; tal fato provoca interferências políticas em suas atribuições, haja vista, por exemplo, o fato de que os cargos de direção são preenchidos mediante indicação dos Ministérios ${ }^{360}$. Critica-se, também, a forma de atuação da Ouvidoria-Geral da União, a qual deveria colher reclamações, encaminhá-las aos órgãos apropriados, efetuar o acompanhamento dessas queixas e sugerir, a partir da análise de problemas comuns, pontos de aprimoramento dos órgãos fiscalizados; essa última etapa, porém, não é realizada.

ii) Instituição Suprema de Auditoria: muito forte. No Brasil, essa função é exercida pelo Tribunal de Contas da União (TCU), cujos nove ministros são protegidos contra

359 O artigo 17 da Lei 10.683/2003 estabelece: “Art. 17. À Controladoria-Geral da União compete assistir direta e imediatamente ao Presidente da República no desempenho de suas atribuições quanto aos assuntos e providências que, no âmbito do Poder Executivo, sejam atinentes à defesa do patrimônio público, ao controle interno, à auditoria pública, à correição, à prevenção e ao combate à corrupção, às atividades de ouvidoria e ao incremento da transparência da gestão no âmbito da administração pública federal. $\S 1^{\circ}$ A Controladoria-Geral da União tem como titular o Ministro de Estado do Controle e da Transparência, e sua estrutura básica é constituída por: Gabinete, Assessoria Jurídica, Conselho de Transparência Pública e Combate à Corrupção, Comissão de Coordenação de Controle Interno, Secretaria-Executiva, Corregedoria-Geral da União, Ouvidoria-Geral da União e 2 (duas) Secretarias, sendo 1 (uma) a Secretaria Federal de Controle Interno. $§ 2^{\circ}$ O Conselho de Transparência Pública e Combate à Corrupção será composto paritariamente por representantes da sociedade civil organizada e representantes do Governo Federal".

O relatório pondera, no entanto, que o Ministério Público, tanto na esfera estadual quanto na federal, exerce importante papel nesse sentido, inclusive com independência em relação aos órgãos por ele fiscalizados. 
interferências políticas mediante garantias constitucionais (vitaliciedade, inamovibilidade e irredutibilidade de vencimentos) ${ }^{361}$. O Relatório Global de Integridade dá ênfase à transparência das decisões do TCU e à importância dada às suas recomendações pelos órgãos fiscalizados.

Ocorre que no relatório não houve uma investigação detalhada em relação às consequências da indicação de ministros que não são originários do próprio TCU, mas oriundos de outras áreas não necessariamente técnicas. Em outras palavras, não foi analisada a qualidade das indicações de ministros ao Tribunal de Contas da União, principalmente quando se percebe que a Constituição somente obriga a indicação de dois funcionários de carreira, permitindo que o restante de vagas seja preenchido por indicações políticas do Presidente da República e, principalmente, do Senado e da Câmara dos Deputados ${ }^{362}$. Aliás, desde a Constituição de 1988, muitos dos nomes indicados foram provenientes do próprio Senado ou da Câmara dos Deputados, denotando o espírito político que permeia as nomeações. Essa falha na nomeação dos integrantes do TCU dificulta a fiscalização do próprio Congresso Nacional pelo tribunal, atribuição que lhe é conferida pelo artigo 56 da Lei de Responsabilidade Fiscal ${ }^{363}$.

Tanto o Senado quanto a Câmara dos Deputados não são imunes à fiscalização. Vale lembrar, inclusive, o recente escândalo dos "atos secretos do Senado", surgido em junho de

361 Tais garantias são, de fato, asseguradas explicitamente pela Constituição Federal: “Art. 73. O Tribunal de Contas da União, integrado por nove Ministros, tem sede no Distrito Federal, quadro próprio de pessoal e jurisdição em todo o território nacional, exercendo, no que couber, as atribuições previstas no art. 96. (...) $\S 3^{\circ}$ Os Ministros do Tribunal de Contas da União terão as mesmas garantias, prerrogativas, impedimentos, vencimentos e vantagens dos Ministros do Superior Tribunal de Justiça, aplicando-selhes, quanto à aposentadoria e pensão, as normas constantes do art. 40. (...)”.

362 De fato, embora o artigo $73, \S 1^{\circ}$, da Constituição Federal, imponha os requisitos para a nomeação de Ministros do Tribunal de Contas da União (mais de trinta e cinco e menos de sessenta e cinco anos de idade; idoneidade moral e reputação ilibada; notórios conhecimentos jurídicos, contábeis, econômicos e financeiros ou de administração pública; mais de dez anos de exercício de função ou de efetiva atividade profissional que exija os conhecimentos mencionados no requisito anterior), o $\S 2^{\circ}$ do mesmo dispositivo autoriza nomeações de funcionários não integrantes da carreira: “Art. 73. (...) $\S 2^{\circ}$ Os Ministros do Tribunal de Contas da União serão escolhidos: I - um terço pelo Presidente da República, com aprovação do Senado Federal, sendo dois alternadamente dentre auditores e membros do Ministério Público junto ao Tribunal, indicados em lista tríplice pelo Tribunal, segundo os critérios de antigüidade e merecimento; II - dois terços pelo Congresso Nacional. (...)”.

363 Assim estabelece o artigo 56 da Lei de Responsabilidade Fiscal: "Art. 56. As contas prestadas pelos Chefes do Poder Executivo incluirão, além das suas próprias, as dos Presidentes dos órgãos dos Poderes Legislativo e Judiciário e do Chefe do Ministério Público, referidos no art. 20, as quais receberão parecer prévio, separadamente, do respectivo Tribunal de Contas. $\S 1^{\underline{0}}$ As contas do Poder Judiciário serão apresentadas no âmbito: I - da União, pelos Presidentes do Supremo Tribunal Federal e dos Tribunais Superiores, consolidando as dos respectivos tribunais; II - dos Estados, pelos Presidentes dos Tribunais de Justiça, consolidando as dos demais tribunais. $\S 2^{\circ} \mathrm{O}$ parecer sobre as contas dos Tribunais de Contas será proferido no prazo previsto no art. 57 pela comissão mista permanente referida no $§ 1^{\circ}$ do art. 166 da Constituição ou equivalente das Casas Legislativas estaduais e municipais. $§ 3^{\text {o }}$ Será dada ampla divulgação dos resultados da apreciação das contas, julgadas ou tomadas”. 
2009 e que consistiu na ausência de publicações de mais de seiscentos atos administrativos realizados em quatorze anos, envolvendo contratações irregulares de pessoal (principalmente de parentes e de aliados de grupos políticos), passagens aéreas, re-embolso de despesas médicas, reformas de apartamento funcional etc. A falta de transparência desses atos prejudicou a devida fiscalização durante os mencionados quatorze anos e possibilitou que houvesse a utilização de recursos públicos para o atingimento de fins particulares.

iii) Tributos e taxas alfandegárias: moderado. Apurou-se que os tributos brasileiros, de um modo geral, não são impingidos de maneira uniforme e nem de forma indiscriminada; o imposto de renda, por exemplo, é pago por alguns cidadãos mediante desconto direto no salário. No pagamento de alguns tributos, principalmente os referentes à transferência de propriedades, os contribuintes adotam mecanismos para evitar seu pagamento integral; o maior índice de evasão é proveniente de empresas. Verificou-se, também, que as leis brasileiras são muito flexíveis e frequentes no que se refere ao estabelecimento de anistias.

iv) Regulação do setor financeiro: muito forte. Apesar dessa denominação, o relatório investiga, na verdade, o grau de fiscalização governamental em relação às empresas de capital aberto, concluindo que o resultado dessa supervisão é transparente e eficaz. Identificou-se que a Comissão de Valores Mobiliários (CVM), órgão que exerce a fiscalização, possui autonomia, funcionários especializados e proteção contra interferências políticas.

v) Licenciamento e regulação de empresas: muito fraco. Apesar de os cidadãos brasileiros possuírem ampla liberdade para requerer a abertura de empresas, tal procedimento é demorado (em São Paulo, por exemplo, o prazo para a conclusão dos trâmites necessários é de 152 dias), com o custo médio de US\$ 340,00 (trezentos e quarenta dólares). Reconhece-se que as exigências legais para a abertura de empresas são transparentes (principalmente no tocante à saúde, segurança e ao meio ambiente), mas as várias legislações existentes, inclusive em diversos níveis (municipal, estadual e federal), incentivam a adoção de práticas corruptas por funcionários públicos. Além disso, as fiscalizações não são realizadas de uma maneira uniforme e equitativa, principalmente aquelas de âmbito municipal.

A última categoria presente no relatório diz respeito à legislação anti-corrupção, que obteve a avaliação moderada. Reconheceu-se que no Brasil existem leis suficientes para a identificação e punição de atos de corrupção, das quais são exemplo a Lei $n^{\circ} 8.429$, de 2 de junho de 1992 (Lei de Improbidade Administrativa), a Lei ${ }^{\circ}$ 1.079, de 10 de abril de 1950 
(Crimes de Responsabilidade), a Lei n 9.613, de 3 de março de 1998 (Crimes de Lavagem de Dinheiro), o Código Penal Brasileiro e as convenções anti-corrupção assinadas pelo Brasil.

No que se refere, contudo, à existência de uma agência anti-corrupção, considerou-se que ela não existe no país, apesar de a Controladoria-Geral da União estar aos poucos desempenhando essa função. Mesmo assim, houve a ressalva de que tal órgão ainda se encontra sujeito a interferências políticas - os cargos de direção são preenchidos mediante nomeação do Ministro - e não possui recursos e requisitos suficientes para ser considerado uma agência anti-corrupção. Em razão dessas considerações, a avaliação apontada para esse item específico foi muito fraco.

No exame do Estado de Direito brasileiro, constatou-se que existem mecanismos recursais para a defesa dos cidadãos na área penal, mas o acesso a tais mecanismos não é barato e se mostra demorado. Nem todos possuem igual acesso ao sistema judiciário, seja porque uma boa defesa é muito cara, seja porque algumas pessoas ou empresas de pequeno porte não conseguem suportar os custos de uma demanda. Apesar dessas deficiências, a avaliação desse item foi forte.

O item referente à aplicação da lei obteve um cômputo final fraco. Constatou-se que: a) o aparato policial não possui recursos suficientes para fazer frente às suas funções; b) a polícia federal possui relativa autonomia, mas as polícias estaduais sofrem interferências políticas; c) a responsabilização dos agentes policiais é dificultada pela ausência de mecanismos eficientes de resposta às reclamações dos cidadãos; d) processar criminalmente policiais é uma prática comum em estados ricos, mas muito rara em estados mais pobres da federação.

A média geral, observados todos os resultados das categorias acima mencionadas, converteu-se numa avaliação moderada das instituições brasileiras. Detectou-se, assim, que tais instituições necessitam de fortalecimento para alcançar níveis de efetivo combate à corrupção e ao desvio de recursos públicos ${ }^{364}$. Nessa esteira, as instituições de âmbito local e regional merecem cuidados redobrados, uma vez que uma descentralização eficiente, em qualquer de suas dimensões, necessita de mecanismos sérios de controle e accountability,

364 Utilizando-se os parâmetros do próprio Relatório Global de Integridade, pode-se afirmar que esses níveis são justamente os que equivalem às avaliações "forte" e "muito forte". 
elementos esses somente possíveis mediante o revigoramento das instituições existentes na circunjacência desses entes.

O estudo contido no Relatório Global de Integridade é relevante porque traz forte subsídio para a teoria de que as instituições, principalmente as políticas, possuem importante papel nos resultados da descentralização fiscal. Ruben Enikolopov e Ekaterina Zhuravskaya, nesse ponto, sustentam que um sistema partidário nacional forte é capaz de conciliar os incentivos políticos dos governantes locais com os objetivos nacionais, permitindo a eficiente prestação de contas em relação aos eleitores da base local. De outro lado, a livre nomeação de pessoas para o exercício de cargos no âmbito da Administração municipal e estadual não concorre para resultados favoráveis em relação à descentralização fiscal ${ }^{365}$.

Com base na função exercida pelas instituições, Robin Boadway e Anwar Shah estabelecem parâmetros diferenciados e hierarquizados para uma política de combate à corrupção, de acordo com a qualidade da governança existente em cada país ${ }^{366}$. De acordo com os autores, se a incidência da corrupção mostra-se alta em um determinado Estado, mas a qualidade da governança é fraca, os esforços de combate à corrupção devem se voltar ao reforço de instituições de participação e accountability, à proteção ao Estado de Direito e aos direitos fundamentais, à execução de reformas na política econômica, bem como à inserção de limites à intervenção governamental ${ }^{367}$. Quando a incidência da corrupção é média e a característica da governança apresentar-se razoável, propõem que o combate à corrupção se volte à descentralização e reforma das políticas econômicas e de gestão pública, assim como

365 Decentralization and political institutions. In: Jounal of Public Economics, v. 91, ns 11-12, Elsevier, dez. 2007, p. 2282. No original: "Our key finding is that political institutions play an important role in determining the results of fiscal decentralization. In line with the predictions of Riker (1964), we find that a strong national party system is a very effective way of aligning political incentives of local politicians with national objectives, while preserving their accountability to local constituencies, which is necessary for efficient decentralization. In developing and transition countries, an older and more stable party system as well as lower fractionalization of government parties is associated with the better effect of fiscal decentralization on economic growth, government quality, and public goods. Our findings also confirm Riker's skepticism about administrative subordination as a mechanism of ensuring efficient political incentives for the local governments in decentralized states: we find that appointing state and municipal officials does not help the results of fiscal decentralization.

Therefore, a remedy to poor governance in large inherently decentralized countries is building strong national political parties whenever possible. Strong parties help to provide elected local officials with efficient political incentives, because their chances of reelection depend both on national party support and the satisfaction of the local constituency. This allows the striking of a balance between national objectives and local accountability".

366 Fiscal Federalism: Principles and Practices of Multiorder Governance. New York: Cambridge University Press, 2009, p. 529.

367 No original: "Establish rule of law, strengthen institutions of participation and accountability, establish citizens' charter, limit government intervention, implement economic policy reforms". 
à implementação da accountability por resultados ${ }^{368}$. Já nos países em que a govenança é boa e a incidência da corrupção mostra-se pequena, os autores sugerem a criação de agências de combate à corrupção, o reforço da accountability, o desenvolvimento da consciência pública e de funcionários do governo, a exigência de compromissos anti-suborno e a condução de processos de grande repercussão ${ }^{369}$.

A adoção das medidas acima, bem como o aprimoramento das instituições existentes no Brasil nas esferas nacional, regional e local, tomando-se como origem os resultados contidos no Relatório Global de Integridade, podem representar o início de uma reação eficaz de combate ao desvio de recursos públicos.

Outro aspecto que merece atenção diz respeito ao controle sobre a atividade financeira do Estado e de todos os órgãos e entidades que administram recursos públicos. No caso do Brasil, que é uma federação de amplas proporções, forçoso reconhecer que não existe um sistema de controle eficiente e adequado no país.

Para essa análise, importante definir o que se entende por sistema. O termo vem do grego systema, que significa "reunião", "grupo". Dentre as várias acepções do termo, Nicola Abbagnano lembra que pode ter o sentido de "conjunto contínuo de partes que têm interrelações diversas" 370 .

Um dos problemas dos órgãos de controle existentes no Brasil é exatamente esse, ou seja, o trabalho ou a fiscalização por eles realizados não apresentam inter-relação. Vale dizer, as atividades executadas pelos diversos tribunais de contas e a Controladoria-Geral da União não apresentam coordenação para o atingimento de fins e metas comuns. Isso significa que eventuais melhorias nos procedimentos de um órgão de fiscalização nem sempre são repassadas aos demais; o mesmo se pode afirmar em relação a informações relevantes em poder desses órgãos. Essa situação não se coaduna com procedimentos de combate à corrupção, por exemplo, que exigem rapidez e eficiência na troca de dados entre os mencionados órgãos.

368 No original: "Decentralize and reform economic policies and public management and introduce accountability for results".

369 No original: "Establish anticorruption agencies, strengthen financial accountability, raise public and official awareness, require antibribery pledges, conduct high-profile prosecutions".

370 Dicionário de filosofia. Tradução de Alfredo Bosi. São Paulo: Martins Fontes, 2007, p. 1077. Título original: Dizionario di Filosofia. Sobre o sistema nas organizações sociais, ver Ludwig Von Bertalanffy (Teoria geral dos sistemas. Tradução de Francisco M. Guimarães. 2a ed. Petrópolis: Editora Vozes, 1975. Título original: General systems theory). Sobre o mesmo assunto, ver, ainda, Daniel Katz e Robert L. Kahn (Psicologia social das organizações. Tradução de Auriphebo Simões. $2^{a}$ ed. São Paulo: Editora Atlas, 1974. Título original: The Social Psychology of Organizations). 
Importante considerar que a impossibilidade de um tribunal de contas se imiscuir nas funções ou decisões de outro, por exemplo, não significa afirmar a impossibilidade de haver coordenação entre eles.

Vale lembrar, ainda, que para a eficiência do sistema há que se ampliar as políticas de capacitação dos cidadãos para exercerem o chamado controle social, munindo-os de informações e técnicas necessárias para a mencionada fiscalização. Aliás, caberia aos órgãos de controle exercer o papel de fomentadores e multiplicadores de tais práticas, uma vez que, principalmente nos entes subnacionais locais, em que não há tribunais de contas, essa função é importante para auxiliar na investigação da aplicação de recursos públicos e para evitar o desvio desses valores ${ }^{371}$.

371 Sobre a importante função exercida pelo controle social, ver Antoninho Marmo Trevisan, Antonio Chizzotti, João Alberto Ianhez, José Chizzotti e Josmar Verillo. O combate à corrupção nas prefeituras do Brasil. $4^{\mathrm{a}}$ ed. Cotia: Ateliê Editorial, 2003. Ver, ainda, Álvaro Martim Guedes e Francisco Fonseca (orgs.). Controle social da administração pública: cenário, avanços e dilemas no Brasil. São Paulo: Cultura Acadêmica/Oficina Municipal; Rio de Janeiro: FGV, 2007. 


\section{Capítulo 4 \\ O ORÇAMENTO, AS TRANSFERÊNCIAS \\ INTERGOVERNAMENTAIS E O DESVIO DE RECURSOS NO \\ BRASIL}

4.1 A ausência de autonomia dos entes subnacionais e a perene dependência em busca de rendas $4.2 \mathrm{O}$ papel do orçamento - 4.3 As peças orçamentárias no ordenamento jurídico brasileiro - $4.4 \mathrm{O}$ procedimento de elaboração da lei orçamentária anual: 4.4.1 A elaboração da proposta da lei orçamentária anual; 4.4.2 A aprovação da lei orçamentária anual - 4.5 Os poderes conferidos ao Congresso Nacional na questão orçamentária e as circunstâncias incentivadoras ao desvio de recursos públicos: 4.5.1 A apresentação de emendas à proposta da lei orçamentária anual, o porkbarrel e a impossibilidade de se alcançar o interesse nacional; 4.5.2 As emendas ao orçamento e a relação dos parlamentares com suas bases eleitorais; 4.5.3 A prática do lobby no processo de emendas ao orçamento e o interesse das empreiteiras; 4.5.4 O poder em mãos do governo central: a troca de favores e a liberação de verbas objeto das emendas. - 4.6 As transferências intergovernamentais: 4.6.1 A utilização das transferências intergovernamentais como forma de proporcionar a equalização fiscal; 4.6.2 Classificação das transferências intergovernamentais; 4.6.3 Os fundos de participação: conceito, características e espécies; 4.6.4 Os critérios de apuração e repartição do Fundo de Participação dos Estados e do Distrito Federal (FPE) e do Fundo de Participação dos Municípios (FPM); 4.6.5 Os fundos de participação e o desvio de recursos públicos no país; 4.6.6 As transferências voluntárias e o desvio de recursos públicos.

\subsection{A ausência de autonomia dos entes subnacionais e a perene dependência em busca de rendas}

Demonstrou-se no capítulo anterior a ausência de autonomia plena das esferas governamentais locais e regionais e a dependência destas por recursos oriundos do poder central. Indicou-se, também, que o poder financeiro ainda permanece concentrado na União, uma vez que o pequeno ganho de autonomia dos entes subnacionais em relação à questão tributária - vantagem essa oriunda da Constituição Federal de 1988 - praticamente se esvaiu com a prevalência de decisões políticas estabelecidas pelo governo central.

A submissão dos entes subnacionais ao governo central ocasiona anomalias à própria federação, desfigurando-a e desviando-a de seus objetivos. 
Em relação aos municípios brasileiros, referida sujeição transparece mais nítida, seja porque muitos deles carecem de autonomia necessária à sua própria manutenção, seja pelo fato de que, comparativamente e proporcionalmente, sua autonomia é menor que a dos Estados e Distrito Federal.

De qualquer forma, o fato é que a situação de dependência dos entes subnacionais por recursos da esfera governamental superior, bem como a maneira pela qual essa sujeição ocorre, criam incentivos para o desvio de recursos e para a má qualidade do gasto público, em franco prejuízo ao interesse público. Vale dizer, o modo como as esferas locais e regionais se movimentam para a obtenção de recursos do poder central pode se caracterizar como incorreto ou danoso ao bem comum, mormente quando tais práticas escondem fins outros que não benefícios em prol da sociedade.

No caso de muitos municípios, por exemplo, constata-se que as lógicas patrimonialista, clientelista e coronelista ainda imperam. Como afirmam Maria Nazaré Lins Barbosa e Virgínia Talaveira Valentini Tristão, pode-se "verificar como alguns traços típicos do 'coronelismo' estão presentes no atual sistema político, com reflexos no quadro orçamentário e tributário, incluindo os mecanismos de repasse de verbas públicas às esferas subnacionais" ${ }^{372}$. Segundo as autoras, a estrutura de submissão ocorre da seguinte forma:

A fraqueza financeira dos municípios alimenta o sistema. As municipalidades não dispõem de recursos para muitas de suas necessidades. Para tanto, é preciso recorrer aos cofres públicos. E, perante os eleitores, fundamentalmente, é o chefe local quem pode obter, por meio de seu empenho e prestígio político, os recursos necessários para os melhoramentos de utilidade pública na localidade. ${ }^{373}$

As relações de dependência se mostram bem claras quando se analisa a luta de estados e municípios em busca de recursos provenientes do orçamento federal. É nessa interação que podem ser observados traços não só do coronelismo, como o incentivo à prática do clientelismo, patrimonialismo, rent-seeking e, também, da corrupção.

Aliás, tal constatação, bem como a de tudo quanto apontado no capítulo anterior, podem ser bem compreendidos quando se analisam dois fatores: o procedimento de

372 Federalismo, Clientelismo e Reforma Fiscal. In: Caderno de Pesquisas em Administração, São Paulo, v. 1 , n. $8,1^{\circ}$ trimestre de 1999, pp. 64-65. Também disponível em www.ead.fea.usp.br/cadpesq/arquivos/c8-Art6.pdf, acessado em 17.07.2008.

373 Maria Nazaré Lins Barbosa e Virgínia Talaveira Valentini Tristão. Federalismo, Clientelismo e Reforma Fiscal. In: Caderno de Pesquisas em Administração, São Paulo, v. 1, n. 8, $1^{\circ}$ trimestre de 1999, pp. 6465. Também disponível em www.ead.fea.usp.br/cad-pesq/arquivos/c8-Art6.pdf, acessado em 17.07.2008. 
elaboração da lei orçamentária do governo federal e a utilização dos recursos dos entes subnacionais provenientes das transferências intergovernamentais.

Os dois mecanismos acima mencionados são importantes para o presente estudo porque retratam os principais instrumentos hoje utilizados pelo federalismo fiscal brasileiro para viabilizar, com a utilização dos recursos nacionais, o equilíbrio federativo e o ajuste de conflitos provocados pelas desigualdades regionais ${ }^{374}$. O dilema, como se verá, está na forma de adoção de tais mecanismos, gerando inconvenientes para a federação e a sociedade brasileira.

\subsection{O papel do orçamento}

A atividade financeira estatal consubstancia-se na obtenção de recursos, na gerência desses haveres e, por fim, na sua aplicação em bens e serviços à população, com a finalidade de satisfazer as necessidades públicas. Atinge-se, dessa forma, a finalidade do Estado, que é proporcionar o bem comum a todos os cidadãos.

O orçamento é o instrumento utilizado para gerenciar esses recursos públicos, pois, de modo geral, "se apresenta como um ato de previsão e de autorização de todos os ingressos e gastos do Estado para um período de tempo determinado",375.

Não por acaso, Gaston Jèze afirma que, sob a ótica financeira, o objetivo do orçamento é "enumerar, avaliar e comparar periodicamente, com antecedência e por certo

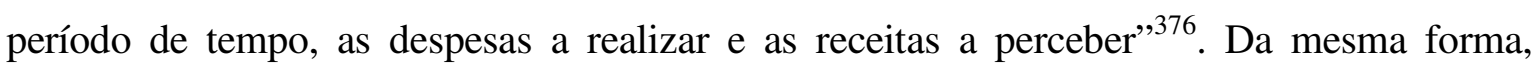
Francesco Nitti propugna que "o orçamento outra coisa não é que o livro documentado das receitas previstas e as despesas acreditadas pelo Estado ou pelos agrupamentos administrativos; é acto que contém a aprovação preventiva das receitas e das despesas públicas",377.

374 Celina Souza. Federalismo e Conflitos Distributivos: Disputa dos Estados por Recursos Orçamentários Federais. In: Dados - Revista de Ciências Sociais. Rio de Janeiro, v. 46, $\mathrm{n}^{\circ}$ 2, 2003, p. 346. Também disponível em http://www.scielo.br/pdf/dados/v46n2/a06v46n2.pdf, acessado em 02.12.2008.

375 Fernando Sainz de Bujanda. Lecciones de Derecho Financiero. $7^{\mathrm{a}}$ ed. Madri: Universidad Complutense/Facultad de Derecho, 1989, p. 431. Tradução livre do autor. No original: "Desde esta perspectiva amplia, el Presupuesto se presenta como un acto de previsión y de autorización de todos los ingresos y gastos del Estado para un período de tiempo determinado".

376 Traité de science des finances: le budget. Paris: V. Giard \& E. Brière, 1910, p. 5. Tradução livre do autor. No original: "Dresser le budget, c'est énumérer, évaluer et comparer périodiquement, à l'avance et pour une période de temps à venir, les dépenses à faire et les recettes à percevoir".

377 Princípios da ciência das finanças. Tradução de C. Machado. Rio de Janeiro: Atena Editora, 1937, v. 2, p. 317. As características apontadas por Gaston Gèze e por Francesco Nitti também são lembradas por 
Constitui-se, na verdade, em instrumento de planejamento da própria atividade financeira estatal, que se inicia com o ingresso de recursos e finda com a aplicação desses recursos em benefício da sociedade ${ }^{378}$. É o que distingue o orçamento de um balanço, por exemplo; enquanto o primeiro representa um "programa financeiro, um plano de ação", o balanço nada mais é que um inventário ou a averiguação do patrimônio ${ }^{379}$. Modernamente, passou-se inclusive a adotar a expressão "orçamento-programa”, que consiste na vinculação, à peça financeira, do planejamento das ações do governo (planos, projetos, obras e serviços) com vistas ao desenvolvimento da sociedade ${ }^{380}$.

O orçamento, no entanto, não se limita apenas à previsão de receitas e à aplicação das despesas, podendo se apresentar sob enfoques diferentes. Sob a ótica econômica, por exemplo, adquire uma concepção dinâmica, passando a ser utilizado propositalmente pelo Estado como instrumento de atuação sobre a economia ${ }^{381}$.

José Joaquim Teixeira Ribeiro (Lições de finanças públicas. $5^{\mathrm{a}}$ ed. atual. Coimbra: Coimbra Editora, 1997, pp. 49-50) quando afirma: "Na verdade, o orçamento é sempre um mapa de previsão. As receitas e despesas que dele constam não são passadas, nem actuais, mas futuras. Ora, o futuro é incerto, e tanto mais incerto, geralmente, quanto mais distante. Torna-se ilusório, portanto, prever todo o futuro; daí que o orçamento tenha de confinar-se a determinado período: é a limitação no tempo. Todavia, o orçamento do Estado - sendo um mapa de previsão das receitas e despesas em certo período, como os demais - é um mapa de receitas cuja obtenção e de despesas cuja realização têm de ser, no nosso como em quase todos os países, autorizadas pelas assembléias representativas."

378 Fernando Sainz de Bujanda. Lecciones de Derecho Financiero. $7^{\text {a }}$ ed. Madri: Universidad Complutense/Facultad de Derecho, 1989, p. 431. No original: "El Presupuesto del Estado, en su sentido más amplio, como plan u ordenación de la actividad financiera del Estado, abarca el ciclo financiero completo, que comienza en el momento en que el Estado detrae la riqueza de las economías de los particulares convirtiéndola en ingresos para cubrir los gastos inherentes a su finalidad de satisfacción de las necesidades públicas, y termina cuando los ingresos se han transformado en servicios públicos o en rentas entregadas por el Estado a las economías privadas."

379 Traité de science des finances: le budget. Paris: V. Giard \& E. Brière, 1910, pp. 5-6. Tradução livre do autor. No original: "Le budget, c'est um programme financier, um plan d'action. Le bilan, c'est la constatation des elements d'un patrimoine; c'est un inventaire”. Essa percepção do orçamento como instrumento de planejamento também é destacada por José Joaquim Teixeira Ribeiro (Lições de finanças públicas. $5^{\text {a }}$ ed. atual. Coimbra: Coimbra Editora, 1997, p. 49) quando afirma: "Não é possível fazer despesas sem receitas correspondentes. Daí que o Estado tenha de prever as suas despesas para saber as receitas de que precisa, e tenha de prever as suas receitas para saber se bastam a cobrir as despesas. Ora, prever receitas ou prever despesas é sempre orçá-las. Por isso o documento onde as receitas e despesas se encontram previstas - melhor dizendo, orçadas - se chama orçamento".

380 José Afonso da Silva. Orçamento-programa no Brasil. São Paulo: Editora Revista dos Tribunais, 1973, p. 41. O mesmo autor complementa que o orçamento-programa "é um documento em que se designam os recursos de trabalho e financeiros destinados à execução dos programas, subprogramas e projetos de execução da ação governamental, classificados por categorias econômicas, por função e por unidades orçamentárias" (Op. cit., p. 41).

381 Carlos M. Giuliani Fonrouge. Derecho Financiero. $2^{\text {a }}$ ed., ampl. e atual. Buenos Aires: Depalma, 1970, v. 1, p. 125. No original: "Podría decirse que ha adquirido una condición dinámica de que antes carecía, pues si bien en su concepción tradicional el presupuesto equilibrado no era forzosamente neutral en sus repercusiones sobre la economía, la diferencia radica en que el efecto otrora admitido es ahora deliberado, intencional, de modo tal que ha pasado a ser un instrumento mediante el cual el Estado actúa sobre la economía". Aliomar Baleeiro (Cinco aulas de finanças e política fiscal. $2^{\mathrm{a}}$ ed. rev. São Paulo: José Bushatsky Editor, 1975, p. 53) demonstra com clareza o aspecto econômico do orçamento: "Sabido 
No tocante ao aspecto político, o orçamento representa "o exercício da soberania pelo parlamento, herdado da tradição britânica originada nos séculos XVII e XVIII" ${ }^{382}$; bem por isso, é utilizado como instrumento de controle da Administração, "que por seu intermédio fica adstrita à execução das despesas no período e nos limites estabelecidos pelo Legislativo" 383 .

A característica acima mencionada possui estreita ligação com o enfoque jurídico, que diz respeito à autorização concedida à Administração Pública para executar a despesa, mas dentro de limites pecuniários estabelecidos no próprio orçamento. Além disso, é o orçamento o responsável por "fixar o emprego ou o destino que deve ser dado aos créditos aprovados no orçamento" 384 .

É justamente sobre a natureza jurídica do orçamento que persistem as maiores divergências na doutrina. Determinados autores sustentam que se trata de uma lei material ${ }^{385}$; outros defendem que é apenas uma lei de caráter formal ${ }^{386}$.

já que os impostos, empréstimos e despesas públicas provocam efeitos inevitáveis sobre os vários aspectos da vida econômica, é óbvio, que, através do orçamento, os governos podem influir decisivamente nas tendências da conjuntura ou nas modificações desejáveis da estrutura. Nenhuma Política Fiscal de combate à depressão, ou à inflação, ou de desenvolvimento, por exemplo, prescinde de ajustamento da lei orçamentária aos seus objetivos".

382 Carlos M. Giuliani Fonrouge. Derecho Financiero. $2^{\mathrm{a}}$ ed., ampl. e atual. Buenos Aires: Depalma, 1970, v. 1, p. 125. Tradução livre do autor. No original: "En aquella época predominaban el aspecto político, relacionado con el ejercicio de la soberanía por el parlamento, heredado de la tradición británica originada en los siglos XVII y XVIII (...)".

383 Ricardo Lobo Torres. Curso de direito financeiro e tributário. $11^{\mathrm{a}}$ ed. atual. Rio de Janeiro: Renovar, 2004, p. 176. No mesmo sentido é o entendimento de Benvenuto Griziotti (Princípios de ciencia de las finanzas. Tradução de Dino Jarach. $6^{\text {a }}$ ed. italiana, acrescida e atualizada. Buenos Aires: Depalma, 1959, p. 37).

384 Fernando Sainz de Bujanda. Lecciones de Derecho Financiero. $7^{\mathrm{a}}$ ed. Madri: Universidad Complutense/Facultad de Derecho, 1989, p. 432. No original: "En segundo lugar, que respecto a los gastos públicos, el Presupuesto produce efectos jurídicos bien precisos en un triple sentido: autorizar a la Administración a realizar el gasto público; limitar las cantidades a gastar hasta un determinado montante y fijar el empleo o destino que haya de darse a los créditos aprobados en el Presupuesto".

385 Fernando Sainz de Bujanda (Lecciones de Derecho Financiero. $7^{\text {a }}$ ed. Madri: Universidad Complutense/Facultad de Derecho, 1989, p. 441), ao analisar a Constituição espanhola de 1978, considera ser o orçamento uma lei capaz de alterar normas de mesmo nível ou até de nível superior. Carlos M. Giuliani Fonrouge (Derecho financiero. $2^{\mathrm{a}}$ ed., ampl. e atual. Buenos Aires: Depalma, 1970, v. 1, p. 146) também entende ser o orçamento uma lei material ao afirmar: "O exposto anteriormente demonstra, também, que a lei do orçamento pode modificar o chamado 'direito objetivo' e também os 'direitos subjetivos' de terceiros, porque - repetimos - não existem limitações à ação do poder legislativo, salvo as que podem resultar dos direitos e garantias essenciais assegurados pela Constituição, cuja apreciação está reservada, entre nós, ao poder judiciário" (tradução livre do autor). No original: "Lo expuesto anteriormente demuestra, asimismo, que la ley de presupuesto puede modificar el llamado 'derecho objetivo' y también los 'derechos subjetivos' de terceros, porque - repetimos - no existen limitaciones a la acción del poder legislativo, salvo las que puedan resultar de los derechos y garantías esenciales asegurados por la Constitución, cuya apreciación está librada, entre nosotros, al poder judicial".

386 Esse é o entendimento de Francesco Nitti (Princípios da ciência das finanças. Tradução de C. Machado. Rio de Janeiro: Atena Editora, 1937, v. 2, p. 345). Geraldo Ataliba (Apontamentos de ciência das 
De qualquer forma, o que interessa ao presente estudo é a importância que o orçamento possui para o Estado e a população que nele vive. Nesse sentido, José Eugénio Dias Ferreira $^{387}$ sintetiza os pontos nos quais se consubstancia tal relevância:

São patentes a importância técnica do orçamento, enquanto este serve para assegurar a distribuição racional das despesas e receitas, facilitando ao mesmo tempo a sua fiscalização, a sua importância econômica, enquanto se propõe satisfazer as necessidades colectivas, tendo em atenção os recursos ou possibilidades de riqueza do país, e a sua importância política, enquanto dá ensejo a criticar os actos da administração, permitindo, consequentemente, exercer pressão sobre os governos.

Dum modo geral, pode dizer-se que o exame do orçamento dum país é sempre muito expressivo, porquanto: pelas despesas, revela o regime político, o sistema de administração, a organização e o funcionamento dos serviços, o grau de adiantamento do mesmo país e, por vezes, a sua actuação na esfera internacional; e, pelas receitas, revela o desenvolvimento da riqueza nacional e as fontes da sua actividade económica.

Percebe-se, dessa forma, que o orçamento está vinculado à ideia de liberdade, seja porque é o veículo pelo qual se permite o exercício da cidadania - por intermédio da fiscalização da população, bem como da pressão por ela exercida sobre o governo para fazer valer o que consta de tal documento -, seja porque a aprovação do orçamento pelo Parlamento revela a liberdade de a sociedade bem dispor dos recursos de seu país ${ }^{388}$.

A concepção subjacente ao orçamento é, assim, a liberdade. Qualquer vício ou mácula no processo de feitura desse documento representará a violação aos princípios fundamentais de direito e poderá, de acordo com sua extensão e gravidade, colocar em risco não apenas o bem comum da população, como também a manutenção do próprio Estado.

finanças, direito financeiro e tributário. São Paulo: Editora Revista dos Tribunais, 1969, p. 54) parece adotar o mesmo posicionamento ao considerar o orçamento uma "lei permissiva", a qual viabiliza que o governo efetue recebimentos e realize despesas. Sudá de Andrade (Apontamentos de ciência das finanças. $2^{\mathrm{a}}$ ed., ampl. e atual. Rio de Janeiro: José Konfino Editor, 1966, p. 205), por sua vez, também defende o caráter de lei formal ao orçamento, considerando-o, da mesma forma que Gaston Jèze (Traité de science des finances: le budget. Paris: V. Giard \& E. Brière, 1910, pp. 53-59, passim), como atocondição. $\mathrm{O}$ ato-condição não se apresenta como uma lei, mas é, na verdade, um requisito necessário para que uma lei possa produzir seus efeitos.

Tratado de finanças públicas: doutrina e legislação portuguesa. Lisboa: Ramos, Afonso \& Moita, Lda., 1950 , v. 2, p. 359.

388 Quanto a esse aspecto, De Plácido e Silva (Noções de finanças e direito fiscal. $2^{\mathrm{a}}$ ed. Curitiba/São Paulo/Rio de Janeiro: Editora Guairá, 1941) assim propugna:

"Por êsse motivo, a fundamental condição de liberdade e independência de um povo assenta no direito que possue de dispor livremente de seus recursos, captando-os e os utilizando, como reflexo de sua soberania, pelos órgãos instituidos pela sua organização política. [...]

Modernamente, os Estados soberanos cercam os orçamentos ou o estruturam segundo as normas e diretrizes, que se têm estabelecido. E tôdas elas trazem o objetivo de impedir as irregularidades na prática ou no desenvolvimento das atividades governamentais em relação à arrecadação das rendas e à aplicação dos dinheiros públicos”. 


\subsection{As peças orçamentárias no ordenamento jurídico brasileiro}

O ordenamento jurídico brasileiro prevê a existência de três peças orçamentárias, cujas leis são de iniciativa do Poder Executivo (artigo 165, da Constituição Federal). São elas: o plano plurianual (PPA), a lei de diretrizes orçamentárias (LDO) e a lei orçamentária anual (LOA).

O plano plurianual (PPA) é a lei que, de forma regionalizada, estabelece "as diretrizes, objetivos e metas da administração pública federal para as despesas de capital e outras delas decorrentes e para as relativas aos programas de duração continuada" (art. 165, § $1^{\circ}$, da Constituição Federal). Representa, segundo José Mauricio Conti, a ferramenta mais importante de planejamento da atuação governamental, embora não seja o único instrumento utilizado pelo governo para esse fim (como é exemplo o Anexo de Metas Fiscais da Lei de Diretrizes Orçamentárias) ${ }^{389}$.

A regulamentação do PPA continua prevista no artigo $35, \S 2^{\circ}$, inciso I, do Ato das Disposições Constitucionais Transitórias, uma vez que o dispositivo da Lei Complementar $n^{\circ}$ 101/2000 (Lei de Responsabilidade Fiscal), que pretendia estabelecer tal regulamentação, foi vetado pelo Presidente da República ${ }^{390}$. Permanece a orientação para que o projeto de PPA seja encaminhado pelo Presidente da República até quatro meses antes do encerramento do primeiro exercício financeiro de seu mandato e devolvido para sanção até o encerramento da sessão legislativa, que ocorre em 22 de dezembro (conforme preceitua o artigo 57, caput, da Constituição Federal) $)^{391}$.

Depreende-se que o PPA, conquanto apresente um período de vigência de quatro anos, não coincide exatamente com o mandato presidencial. O projeto de plano plurianual de um determinado Presidente da República somente vigorará a partir do segundo ano de seu mandato, mas vigorará até o primeiro ano de mandato de seu sucessor.

O benefício advindo com o plano plurianual é que, ao contrário das demais peças orçamentárias (LDO e LOA), estabelece metas e programas em longo prazo e a previsão de

389 Da proposta orçamentária: Da elaboração da proposta orçamentária. In: CONTI, José Mauricio (coord.). Orçamentos públicos: a Lei 4.320/1964 comentada. São Paulo: Editora Revista dos Tribunais, 2008, p. 95.

390 O dispositivo vetado é o artigo $3^{\circ}$ da Lei de Responsabilidade Fiscal.

391 O artigo 35, $\S 2^{\circ}$, inciso I, do Ato das Disposições Constitucionais Transitórias é claro nesse sentido ao estabelecer: "o projeto do plano plurianual, para vigência até o final do primeiro exercício financeiro do mandato presidencial subseqüente, será encaminhado até quatro meses antes do encerramento do primeiro exercício financeiro e devolvido para sanção até o encerramento da sessão legislativa”. 
recursos para o período correspondente, permitindo a continuidade de projetos já $\operatorname{programados}^{392}$.

A lei de diretrizes orçamentárias (LDO) tem como finalidade prever as metas e prioridades da administração pública federal, aí incluídas as despesas de capital, direcionar a elaboração da lei orçamentária anual (LOA), deliberar sobre as modificações na legislação tributária e instituir a política de aplicação das agências financeiras oficiais de fomento ${ }^{393}$. A LDO retira do plano plurianual metas e programas que deverão ser contemplados na lei orçamentária anual.

Além disso, possui outras funções, tais como a de autorizar expressamente a concessão de vantagens ou aumento de remuneração, a criação de cargos, empregos e funções, a modificação da estrutura de carreiras e a admissão ou contratação de pessoal pelos órgãos e entidades da administração direta ou indireta (ressalvadas as empresas públicas e as sociedades de economia mista) ${ }^{394}$.

Outros objetivos da LDO também são descritos na Lei de Responsabilidade Fiscal, dentre os quais a disposição sobre o equilíbrio entre receitas e despesas, os critérios para a limitação de empenho, as condições e exigências para transferências de recursos a entidades públicas e privadas e as normas referentes ao controle de custos e à avaliação dos resultados dos programas financiados com recursos orçamentários ${ }^{395}$.

A LDO é uma lei anual, integrada por dois anexos principais, o de metas fiscais e o de riscos fiscais. O primeiro representa um dos documentos de planejamento da ação governamental, pois dispõe sobre as metas anuais para o próprio exercício e para os dois posteriores, contemplando receitas, despesas, resultados nominal e primário, bem como o montante da dívida pública ${ }^{396}$. Como leciona Regis Fernandes de Oliveira, “o Anexo de

392 José Augusto Moreira de Carvalho. As parcerias público-privadas e a atividade financeira do Estado. Dissertação de Mestrado. São Paulo: Universidade de São Paulo - Faculdade de Direito, 2006, p. 79.

393 Artigo $165, \S 2^{\circ}$, da Constituição Federal.

394 Artigo $169, \S 1^{\circ}$, inciso II, da Constituição Federal.

395 Artigo $4^{\circ}$, inciso I, da Lei de Responsabilidade Fiscal.

396 Artigo $4^{\circ}, \S 1^{\circ}$, da Lei de Responsabilidade Fiscal. O parágrafo segundo do mesmo dispositivo relaciona outros conteúdos do Anexo de Metas Fiscais, quais sejam: "I - avaliação do cumprimento das metas relativas ao ano anterior; II - demonstrativo das metas anuais, instruído com memória e metodologia de cálculo que justifiquem os resultados pretendidos, comparando-as com as fixadas nos três exercícios anteriores, e evidenciando a consistência delas com as premissas e os objetivos da política econômica nacional; III - evolução do patrimônio líquido, também nos últimos três exercícios, destacando a origem e a aplicação dos recursos obtidos com a alienação de ativos; IV - avaliação da situação financeira e atuarial: a) dos regimes geral de previdência social e próprio dos servidores públicos e do Fundo de Amparo ao Trabalhador; b) dos demais fundos públicos e programas estatais de natureza atuarial; V - 
Metas é essencial para que se possa controlar a Administração Pública. Traçados os vetores, através da lei, os objetivos devem ser alcançados" ${ }^{\text {397 }}$. Já o anexo de riscos fiscais tem como finalidade apurar e propor soluções para eventuais passivos contingentes e outros riscos que possam influenciar negativamente as contas públicas; representa, também, um recurso para o planejamento da atuação governamental ${ }^{398}$.

Um dos objetivos principais da lei de diretrizes orçamentárias é atuar como instrumento intermediário entre o plano plurianual e a lei orçamentária anual. Vale dizer, funciona como mecanismo de ajuste e equalização entre o que fora definido no PPA e a situação vivenciada no momento (com variáveis econômicas, políticas, sociais etc.), que resultará na elaboração da lei orçamentária anual ${ }^{399}$.

A lei orçamentária anual (LOA) tem como finalidade detalhar as despesas e receitas para a consecução do quanto previsto na lei de diretrizes orçamentárias. Não por acaso, o artigo $5^{\circ}$ da Lei de Responsabilidade Fiscal prevê que o projeto de lei orçamentária anual deverá ser elaborado de forma compatível tanto com a lei de diretrizes orçamentárias quanto com o plano plurianual. As peças orçamentárias devem representar, dessa forma, um todo coeso, harmônico e vinculado, devendo o que for determinado na LOA estar previsto na LDO e, se o caso, contemplado também no $\mathrm{PPA}^{400}$.

demonstrativo da estimativa e compensação da renúncia de receita e da margem de expansão das despesas obrigatórias de caráter continuado".

397 Responsabilidade fiscal. $2^{\text {a }}$ ed. rev. São Paulo: Editora Revista dos Tribunais, 2002, p. 32.

398 Artigo $4^{\circ}, \S 3^{\circ}$, da Lei de Responsabilidade Fiscal. Importante lembrar que, no âmbito federal, a Lei de Responsabilidade Fiscal dispõe sobre a exigência de mais um anexo, que conterá "os objetivos das políticas monetária, creditícia e cambial, bem como os parâmetros e as projeções para seus principais agregados e variáveis, e ainda as metas de inflação, para o exercício subseqüente" (artigo $4^{\circ}$, $4^{\circ}$ ).

399 Importantes observações nesse sentido são expostas por Claudiano Albuquerque, Márcio Medeiros e Paulo Henrique Feijó (Gestão de finanças públicas: fundamentos e práticas de planejamento, orçamento e administração financeira com responsabilidade fiscal. $2^{a}$ ed. Brasília: Editora Gestão Pública, 2008, p. 164): "Ao situar-se em uma posição intermediária entre as diretrizes, objetivos e metas, definidas no plano plurianual, e a previsão da receita e fixação da despesa, próprias da lei orçamentária anual, a Lei de Diretrizes Orçamentárias cumpre papel de balanceamento entre a estratégia traçada no início de um governo e as reais possibilidades que vão se apresentando ao longo dos anos de implementação do plano plurianual.

Diante da necessidade de se ajustar a programação prevista no plano plurianual ao cenário político, econômico e institucional que se apresenta nos meses que antecedem a elaboração e análise da proposta orçamentária, a Lei de Diretrizes Orçamentárias tem o poder de antecipar um fato inevitável: a necessidade de se fazer escolhas.

Por mais que haja a preocupação com o equilíbrio fiscal em sua elaboração, as metas (plurianuais) estabelecidas no plano plurianual, invariavelmente, demandam mais recursos do que um orçamento anual pode dispor. Sendo assim, há que se priorizar umas em detrimento de outras.

A antecipação dessa decisão, proposta pelo Poder Executivo no projeto da LDO e analisada, aperfeiçoada e aprovada pelo Poder Legislativo, deve servir para orientar a elaboração de proposta orçamentária que goze de aceitação pelos dois poderes responsáveis pelo processo de formulação e aprovação da mesma".

400 Principalmente quando se referir a despesas que ultrapassam mais de um exercício financeiro. 
A LOA, como o próprio nome indica, tem periodicidade anual, compreendido dentro do exercício financeiro, que se refere "ao espaço temporal em que as receitas e as despesas previstas no orçamento deverão ser concretizadas" ${ }^{\text {401 }}$. A Lei 4.320, de 17 de março de 1964, em seu artigo 34, estabelece que "o exercício financeiro coincidirá com o ano civil”, ou seja, de $1^{\circ}$ de janeiro a 31 de dezembro ${ }^{402}$.

Estão compreendidos na lei orçamentária anual: a) o orçamento fiscal, que contém as receitas e despesas atinentes aos Poderes da União, fundos, órgãos e entidades da administração direta e indireta e fundações mantidas e instituídas pelo Poder Público; b) o orçamento de investimento das empresas estatais federais; c) o orçamento da seguridade social $^{403}$.

\subsection{O procedimento de elaboração da lei orçamentária anual}

O estudo se deterá à análise do procedimento de elaboração da lei orçamentária anual, que apresenta maiores detalhes e implicações referentes à atuação de grupos de pressão e à presença de características relacionadas ao patrimonialismo e ao clientelismo. $\mathrm{O}$ referido procedimento compreende dois momentos: a) elaboração da proposta orçamentária; b) discussão, votação e aprovação da lei orçamentária.

\subsubsection{A elaboração da proposta da lei orçamentária anual}

O estágio de elaboração da proposta orçamentária representa a fase administrativa, que "compreende o período que vai do início das previsões e cálculos nas várias unidades orçamentárias e demais órgãos que integram o processo de elaboração da lei orçamentária, até o momento em que se finaliza a proposta de lei orçamentária"404.

401 CARVALHO, José Augusto Moreira de. Do exercício financeiro. In: CONTI, José Mauricio (coord.). Orçamentos públicos: a Lei 4.320/1964 comentada. São Paulo: Editora Revista dos Tribunais, 2008, p. 121.

402 O dispositivo da mencionada Lei 4.320/64 vem disciplinar o disposto no inciso I, do $\S 9^{\circ}$, do artigo 165 , da Constituição Federal, o qual estabelece que cabe à lei complementar dispor sobre o exercício financeiro.

403 Artigo 165, § $5^{\circ}$, incisos I a III, da Constituição Federal.

404 José Maurício Conti. Da proposta orçamentária: Da elaboração da proposta orçamentária. In: CONTI, José Mauricio (coord.). Orçamentos públicos: a Lei 4.320/1964 comentada. São Paulo: Editora Revista dos Tribunais, 2008, p. 119. 
No âmbito da União, de acordo com a Lei $n^{\circ} 10.180$, de 6 de fevereiro de $2001^{405}$, a etapa de elaboração é desenvolvida por intermédio do Sistema de Planejamento e de Orçamento Federal, que possui as seguintes atribuições: a) formular o planejamento estratégico nacional, os planos nacionais, setoriais e regionais de desenvolvimento econômico e social, o plano plurianual, as diretrizes orçamentárias e os orçamentos anuais; b) administrar o processo de planejamento e orçamento federal; c) viabilizar a articulação com os demais entes da federação, com vistas a harmonizar normas e tarefas relacionadas aos sistemas de âmbito federal, estadual, distrital e municipal ${ }^{406}$.

Integram o referido sistema: a) o Ministério do Planejamento, Orçamento e Gestão, como órgão central; b) órgãos setoriais, que são as unidades de planejamento e orçamento dos Ministérios, da Advocacia-Geral da União, da Vice-Presidência e da Casa Civil da Presidência da República; c) órgãos específicos, que são aqueles vinculados ou subordinados ao órgão central do sistema ${ }^{407}$.

O Ministério do Planejamento, Orçamento e Gestão atribui à Secretaria de Orçamento Federal (SOF) as funções de coordenação, consolidação e supervisão na elaboração da proposta de orçamento anual. Aos órgãos setoriais incumbe a responsabilidade de identificar as despesas relacionadas a cada uma de suas áreas, enquanto que os órgãos específicos têm como objetivo as funções de planejamento e orçamento.

Existem, ainda, as unidades orçamentárias, definidas como "o agrupamento de serviços subordinados ao mesmo órgão ou repartição a que serão consignadas dotações próprias" 408 e que têm como atribuição coordenar "o processo de elaboração da proposta orçamentária no seu âmbito de atuação, integrando e articulando o trabalho das unidades administrativas componentes" 409 .

O processo de elaboração da proposta orçamentária compreende algumas etapas. A primeira diz respeito ao estabelecimento, pelo órgão central (Ministério do Planejamento, Orçamento e Gestão), de orientações gerais para a preparação do orçamento federal anual.

\footnotetext{
405 A mencionada norma dispõe sobre os Sistemas de Planejamento e de Orçamento Federal, de Administração Financeira Federal, de Contabilidade Federal e de Controle Interno do Poder Executivo Federal.

406 Artigo $2^{\circ}$ da Lei $10.180 / 2001$.

407 Artigo $4^{\circ}$ da Lei $10.180 / 2001$.

408 Artigo 14 da Lei 4.320/64.

409 José Maurício Conti. Da proposta orçamentária: Da elaboração da proposta orçamentária. In: CONTI, José Mauricio (coord.). Orçamentos públicos: a Lei 4.320/1964 comentada. São Paulo: Editora Revista dos Tribunais, 2008, pp. 101-102.
} 
O estágio seguinte refere-se à estimativa da receita que, nos dizeres de José Maurício Conti $^{410}$, representa

[...] uma questão complexa, pois envolve previsões de arrecadação de tributos e também receitas de outras fontes, cujos valores estão sujeitos, na maior parte dos casos, às variações do comportamento do mercado nacional e internacional, além de conjunturas políticas e outras circunstâncias difíceis de se prever com precisão, tais como câmbio, juros, inflação, crescimento da economia, nível de endividamento e outros. Dependem de informações de outros órgãos, em especial daqueles ligados à arrecadação tributária, como o Ministério da Fazenda, bem como todos os demais que tenham fontes próprias de arrecadação. Além disso, há divergências quanto aos critérios a serem adotados em diversos aspectos da elaboração desses cálculos. A estimativa da receita pública, a par das dificuldades enfrentadas, é de grande relevância para a elaboração orçamentária, pois os valores nela previstos servirão de base para a fixação das despesas públicas e, conseqüentemente, para o cálculo das dotações a cada um dos programas existentes.

A fase posterior diz respeito à determinação das bases monetárias, cujos dados serão utilizados pelos órgãos setoriais para a confecção do projeto do orçamento anual. Nesse estágio, o órgão central também estabelece os limites para as propostas de despesa por parte dos órgãos setoriais.

Concluída a proposição orçamentária dos órgãos setoriais, ela é encaminhada ao órgão central, que por intermédio da Secretaria de Orçamento Federal efetua sua compatibilização com os termos da Constituição Federal, do plano plurianual, da lei de diretrizes orçamentárias e da Lei de Responsabilidade Fiscal. Após essa verificação, a proposta é consolidada, formalizada e enviada à Presidência da República que, se de acordo, a encaminha para o Congresso Nacional ${ }^{411}$.

Na fase de elaboração da proposta orçamentária existem incentivos ao desvio de recursos, mesmo porque o Brasil "não adota a técnica do 'orçamento base zero', que tem como fundamento a obrigatoriedade do administrador de justificar todos os recursos pleiteados"412. O país se utiliza, na verdade, de um mecanismo cuja estrutura "é a

410 A autonomia financeira do poder judiciário. São Paulo: MP Editora, 2006, p. 79.

411 Assim determina o artigo 84, inciso XXIII, da Constituição Federal: “Art. 84. Compete privativamente ao Presidente da República: (...) XXIII - enviar ao Congresso Nacional o plano plurianual, o projeto de lei de diretrizes orçamentárias e as propostas de orçamento previstos nesta Constituição". O artigo 166, caput, da mesma Carta Constitucional, determina que "os projetos de lei relativos ao plano plurianual, às diretrizes orçamentárias, ao orçamento anual e aos créditos adicionais serão apreciados pelas duas Casas do Congresso Nacional, na forma do regimento comum”. Para maiores detalhes, inclusive práticos, sobre a elaboração da proposta de lei orçamentária anual no âmbito federal, ver Manual Técnico de Orçamento MTO: Versão 2010. Brasília: Ministério do Planejamento, Orçamento e Gestão - Secretaria de Orçamento Federal, 2009; também disponível em https://www.portalsof.planejamento.gov.br/bib/MTO/MTO_2010_VF6.pdf, acessado em 26.12.2009.

412 José Maurício Conti. A autonomia financeira do poder judiciário. São Paulo: MP Editora, 2006, p. 80. 
manutenção dos gastos que já vinham sendo feitos em exercícios anteriores, justificando-se tão-somente os incrementos incorporados ao novo orçamento" ${ }^{413}$.

A ausência dessa fundamentação é capaz de estimular o escamoteamento de despesas e, no mínimo, prejudicar a qualidade do gasto público, uma vez que pode provocar a aplicação de recursos em gastos desnecessários ${ }^{414}$.

\subsubsection{A aprovação da lei orçamentária anual}

A partir do momento em que, por intermédio do Presidente do Senado, o Congresso Nacional recebe o projeto de lei, inicia-se a fase legislativa da elaboração do orçamento anual, que tem o seu término com a promulgação da lei respectiva ${ }^{415}$. O trâmite legislativo do projeto da lei orçamentária anual e das demais peças orçamentárias (PPA e LDO) é disciplinado pela Resolução n ${ }^{\circ}$, de 22 de dezembro de 2006-CN (Congresso Nacional).

Após o recebimento do projeto pelo Congresso Nacional, é ele publicado e enviado à Comissão Mista de Planos, Orçamentos Públicos e Fiscalização (CMO) ${ }^{416}$, composta de quarenta membros titulares, sendo trinta deputados e dez senadores, com o mesmo número de suplentes ${ }^{417}$. A CMO possui um Presidente e três Vice-Presidentes, os quais são eleitos

413 José Maurício Conti. A autonomia financeira do poder judiciário. São Paulo: MP Editora, 2006, p. 80.

414 Nesse sentido, José Joaquim Teixeira Ribeiro (Lições de finanças públicas. $5^{\mathrm{a}}$ ed. atual. Coimbra: Coimbra Editora, 1997, p. 107) esclarece: “Já que se observa, não só entre nós como lá fora a tendência de muitos serviços por uma questão de facilidade e segurança, preverem as despesas do ano seguinte mediante uma revisão das verbas que lhes foram assinadas no orçamento em curso, aumentando-as. Trata-se de um sistema incrementalista de avaliação das despesas, que não pode deixar de ter por conseqüência muitos gastos supérfluos e, até, inúteis".

415 De fato, determina o artigo 89 do Regimento Comum do Congresso Nacional (Resolução n 1 , de 1970CN): “Art. 89. A Mensagem do Presidente da República encaminhando projeto de lei orçamentária será recebida e lida em sessão conjunta, especialmente convocada para esse fim, a realizar-se dentro de 48 (quarenta e oito) horas de sua entrega ao Presidente do Senado".

416 Conforme dispõe o artigo 166 e $\S 1^{\circ}$, da Constituição Federal: "Art. 166. Os projetos de lei relativos ao plano plurianual, às diretrizes orçamentárias, ao orçamento anual e aos créditos adicionais serão apreciados pelas duas Casas do Congresso Nacional, na forma do regimento comum. $\S 1^{\circ}$ Caberá a uma Comissão mista permanente de Senadores e Deputados: I - examinar e emitir parecer sobre os projetos referidos neste artigo e sobre as contas apresentadas anualmente pelo Presidente da República; II examinar e emitir parecer sobre os planos e programas nacionais, regionais e setoriais previstos nesta Constituição e exercer o acompanhamento e a fiscalização orçamentária, sem prejuízo da atuação das demais comissões do Congresso Nacional e de suas Casas, criadas de acordo com o art. 58".

417 Art. $5^{\circ}$ da Resolução $n^{\circ} 1$, de 2006-CN, norma que dispõe sobre a Comissão Mista Permanente a que se refere o artigo $166, \S 1^{\circ}$, da Constituição Federal. $\mathrm{O}$ artigo $2^{\circ}$ da mesma Resolução dispõe sobre a competência da Comissão Mista de Planos, Orçamentos Públicos e Fiscalização (CMO): “Art. $2^{\circ}$ A CMO tem por competência emitir parecer e deliberar sobre: I - projetos de lei relativos ao plano plurianual, diretrizes orçamentárias, orçamento anual e créditos adicionais, assim como sobre as contas apresentadas nos termos do art. 56, caput e $\S 2^{\circ}$, da Lei Complementar $n^{\circ} 101$, de 4 de maio de 2000; II - planos e programas nacionais, regionais e setoriais, nos termos do art. 166, § $1^{\circ}$, II, da Constituição; III - documentos pertinentes ao acompanhamento e fiscalização da execução orçamentária e financeira e da 
pelos próprios pares, com mandato anual ${ }^{418}$. Compõem a Comissão, também, o RelatorGeral, o Relator da Receita e os Relatores Setoriais ${ }^{419}$.

O projeto de lei orçamentária anual é dividido em áreas temáticas, cujos relatórios são de responsabilidade dos Relatores Setoriais, os quais debatem o projeto nas Comissões Permanentes, podendo se valer da contribuição de representantes da sociedade civil. Assim estão divididas as áreas temáticas: a) Infraestrutura; b) Saúde; c) Integração Nacional e Meio Ambiente; d) Educação, Cultura, Ciência e Tecnologia e Esporte; e) Planejamento e Desenvolvimento Urbano; f) Fazenda, Desenvolvimento e Turismo; g) Justiça e Defesa; h) Poderes do Estado e Representação; i) Agricultura e Desenvolvimento Agrário; j) Trabalho, Previdência e Assistência Social ${ }^{420}$.

A CMO viabiliza discussões sobre o projeto de lei mediante audiências públicas (inclusive de temas referentes aos campos temáticos regimentais) ${ }^{421}$, recebendo, também,

gestão fiscal, nos termos dos arts. 70 a 72 e art. 166, $\S 1^{\circ}$, II, da Constituição, e da Lei Complementar $n^{\circ}$ 101, de 2000, especialmente sobre: a) os relatórios de gestão fiscal, previstos no art. 54 da Lei Complementar $\mathrm{n}^{\circ} 101$, de 2000; b) as informações encaminhadas pelo Tribunal de Contas da União relativas à fiscalização de obras e serviços em que foram identificados indícios de irregularidades graves e relacionados em anexo à lei orçamentária anual, nos termos da lei de diretrizes orçamentárias; c) as demais informações encaminhadas pelo Tribunal de Contas da União ou por órgãos e entidades da administração federal, por intermédio do Congresso Nacional; d) os relatórios referentes aos atos de limitação de empenho e movimentação financeira, nos termos do art. $9^{\circ}$ da Lei Complementar $n^{\circ} 101$, de 2000, e demais relatórios de avaliação e de acompanhamento da execução orçamentária e financeira, nos termos da lei de diretrizes orçamentárias; e e) as informações prestadas pelo Poder Executivo, ao Congresso Nacional, nos termos dos $\S \S 4^{\circ}$ e $5^{\circ}$ do art. $9^{\circ}$ da Lei Complementar $n^{\circ} 101$, de 2000; IV demais atribuições constitucionais e legais. $\S 1^{\circ}$ A CMO organizará a reunião conjunta de que trata o art. $9^{\circ}, \S 5^{\circ}$, da Lei Complementar $n^{\circ} 101$, de 2000, em articulação com as demais Comissões Permanentes das Casas do Congresso Nacional. § $2^{\circ}$ A CMO poderá, para fins de observância do disposto no art. 17 da Lei Complementar $\mathrm{n}^{\circ} 101$, de 2000, observados os Regimentos Internos de cada Casa, antes da votação nos respectivos plenários, ser ouvida acerca da estimativa do custo e do impacto fiscal e orçamentário da aprovação de projetos de lei e medidas provisórias em tramitação".

418 Art. 12 da Resolução n ${ }^{\circ} 1$, de 2006-CN. O artigo 13 da mesma Resolução disciplina como será a eleição dos Presidentes e Vice-Presidentes: “Art. 13. As funções de Presidente e Vice-Presidente serão exercidas, a cada ano, alternadamente, por representantes do Senado Federal e da Câmara dos Deputados, observado o disposto no $\S 1^{\circ}$ deste artigo. $\S 1^{\circ}$ A primeira eleição, no início de cada legislatura, para Presidente e $2^{\circ}$ Vice-Presidente, recairá em representantes do Senado Federal e a de $1^{\circ} \mathrm{e}$ $3^{\circ}$ Vice-Presidentes em representantes da Câmara dos Deputados. $\S 2^{\circ} \mathrm{O}$ suplente da CMO não poderá ser eleito para as funções previstas neste artigo".

419 Art. 17, caput, da Resolução ${ }^{\circ}$ 1, de 2006-CN. De acordo com o artigo 18 da mesma Resolução, os Relatores Setoriais e o Relator-Geral integrarão o Comitê de Avaliação, Controle e Fiscalização da Execução Orçamentária, enquanto que o Relator da Receita integrará e coordenará o Comitê de Avaliação da Receita. Referidos comitês, juntamente com o Comitê de Avaliação das Informações sobre Obras e Serviços com Indícios de Irregularidades Graves e o Comitê de Exame da Admissibilidade de Emendas, formam os comitês permanentes da CMO. Art. 26, caput, da Resolução n ${ }^{\circ} 1$, de 2006-CN.

421 Art. 29 da Resolução n 1, de 2006-CN: “Art. 29. A CMO realizará audiências públicas para o debate e o aprimoramento do projeto, para as quais convidará Ministros ou representantes dos órgãos de Planejamento, Orçamento e Fazenda do Poder Executivo e representantes dos órgãos e entidades integrantes das áreas temáticas. $\S 1^{\circ}$ As audiências públicas que tiverem como objeto o debate de assuntos relacionados aos campos temáticos regimentais das Comissões Permanentes do Senado Federal 
contribuições das Comissões Permanentes da Câmara dos Deputados e do Senado Federal ${ }^{422}$. A previsão de realização de audiências públicas, aliás, vai ao encontro da transparência da gestão fiscal, princípio esse expressamente contido na Lei de Responsabilidade Fiscal e que, em seu artigo 48, parágrafo único, estabelece que "a transparência será assegurada também mediante incentivo à participação popular e realização de audiências públicas, durante os processos de elaboração e discussão dos planos, lei de diretrizes orçamentárias e orçamentos" $" 423$.

Paralelamente a esses procedimentos, é aberto prazo para encaminhamento de emendas à receita ou de renúncia de receitas ao projeto de lei orçamentária. São consideradas emendas à receita aquelas que "têm por finalidade alteração da estimativa da receita, inclusive as que propõem redução dessa estimativa em decorrência de projeto de lei”424. Já as emendas de renúncia de receitas, como a própria designação indica, referem-se à abdicação

e da Câmara dos Deputados serão realizadas sob a coordenação da CMO, na forma de reuniões conjuntas. $\S 2^{\circ} \mathrm{A}$ CMO poderá realizar audiências públicas regionais para debater o projeto, quando de interesse de Estado ou Região Geográfica".

422 Regimento Comum do Congresso Nacional (Resolução n ${ }^{\circ}$, de 1970-CN): "Art. 90. O projeto de lei orçamentária será apreciado por uma Comissão Mista que contará com a colaboração das Comissões Permanentes da Câmara dos Deputados e do Senado Federal. § $1^{\circ}$ (revogado pela Resolução $n^{\circ} 1$, de 1991-CN, com a redação dada pela Resolução ${ }^{\circ} 1$, de 1993-CN). § $2^{\circ}$ O Suplente só participará dos trabalhos da Comissão Mista na ausência ou impedimento de membro titular. $\S 3^{\circ} \mathrm{A}$ participação das Comissões Permanentes, no estudo da matéria orçamentária, obedecerá às seguintes normas: a) as Comissões Permanentes interessadas, uma vez constituída a Comissão Mista, deverão solicitar ao Presidente desta, lhe seja remetido o texto do projeto de lei orçamentária; b) a Comissão Mista, ao encaminhar o projeto à solicitante, estabelecerá prazos e normas a serem obedecidos na elaboração de seu parecer, o qual deverá abranger, exclusivamente, as partes que versarem sobre a matéria de sua competência específica; c) a Comissão Permanente emitirá parecer circunstanciado sobre o anexo que lhe for distribuído e elaborará estudo comparativo dos programas e dotações propostas com a prestação de contas do exercício anterior e, sempre que possível, com a execução da lei orçamentária em vigor; d) o parecer da Comissão Permanente será encaminhado, pelo Presidente da Comissão Mista, ao relator respectivo para que sirva como subsídio ao estudo da matéria; e) o parecer do relator da Comissão Mista deverá fazer referência expressa ao ponto de vista expendido pela Comissão Permanente; f) por deliberação da maioria de seus membros, as Comissões Permanentes do Senado e da Câmara dos Deputados, que tiverem competência coincidente, poderão realizar reuniões conjuntas sob a direção alternada dos respectivos Presidentes, podendo concluir pela apresentação de parecer único; e g) os pareceres das Comissões Permanentes, que concluírem pela apresentação de emendas, deverão ser encaminhados à Comissão Mista dentro do prazo estabelecido na Resolução ${ }^{\circ} 1$, de $2001-\mathrm{CN}$. $\S 4^{\circ} \mathrm{As}$ deliberações da Comissão Mista iniciar-se-ão pelos representantes da Câmara dos Deputados, sendo que o voto contrário da maioria dos representantes de uma das Casas importará na rejeição da matéria. $\S 5^{\circ}$ Na eleição do Presidente e do Vice-Presidente da Comissão, não se aplicam as disposições do $§ 4^{0}$ ”.

Lembra-se que a própria lei orçamentária representa um mecanismo de transparência da gestão fiscal. O caput do artigo 48, da Lei de Responsabilidade Fiscal é categórico nesse sentido: "Art. 48. São instrumentos de transparência da gestão fiscal, aos quais será dada ampla divulgação, inclusive em meios eletrônicos de acesso público: os planos, orçamentos e leis de diretrizes orçamentárias; as prestações de contas e o respectivo parecer prévio; o Relatório Resumido da Execução Orçamentária e o Relatório de Gestão Fiscal; e as versões simplificadas desses documentos". 
de recursos decorrente de projeto de lei de iniciativa do Congresso Nacional ${ }^{425}$; referidas emendas somente serão aprovadas se houver a indicação de compensações oriundas de anulação de despesas ou do acréscimo de outras receitas ${ }^{426}$.

O estudo das emendas mencionadas é atribuição do Relator da Receita. Além dessa função, é ele também o responsável pela verificação da correção da estimativa de receita efetuada pelo Poder Executivo, utilizando-se para tanto da metodologia contida na lei de diretrizes orçamentárias e valendo-se do auxílio do Comitê de Avaliação da Receita ${ }^{427}$. Concretizadas as análises, o Relatório da Receita é encaminhado à CMO para aprovação ${ }^{428}$.

Em seguida à apreciação do Relatório da Receita, caberá ao Relator-Geral do projeto de lei orçamentária elaborar Relatório Preliminar, que também deverá ser submetido à aprovação da CMO, situação após a qual o documento passará a se denominar Parecer Preliminar. No citado relatório devem constar as diretrizes e as regras que deverão ser

425 Art. 32, caput, da Resolução n ${ }^{\circ}$ 1, de 2006-CN. O mesmo dispositivo, em seus incisos I e II, menciona as condições para que a emenda seja considerada como de renúncia de receita: “Art. 32. (...) I - tenha recebido, previamente ao exame da compatibilidade e da adequação orçamentária e financeira, parecer favorável de mérito, na Casa de origem, pelas Comissões Permanentes; II - esteja, até o prazo final para a apresentação de emendas, instruído com a estimativa da renúncia de receita dele decorrente, oriunda do Poder Executivo ou de órgão técnico especializado em matéria orçamentária do Poder Legislativo".

426 Art. 32, parágrafo único, da Resolução $n^{\circ} 1$, de 2006-CN. Deve-se atentar, contudo, que o artigo 41 da mesma resolução estabelece outras condições para a aprovação da emenda: "Art. 41. A emenda ao projeto que propõe acréscimo ou inclusão de dotações, somente será aprovada caso: I - seja compatível com a lei do plano plurianual e com a lei de diretrizes orçamentárias; II - indique os recursos necessários, admitidos apenas os provenientes de anulação de despesas, excluídas as que incidam sobre: a) dotações para pessoal e seus encargos; b) serviço da dívida; c) transferências tributárias constitucionais para Estados, Municípios e Distrito Federal; III - não seja constituída de várias ações que devam ser objeto de emendas distintas; e IV - não contrarie as normas desta Resolução, bem como as previamente aprovadas pela CMO. Parágrafo único. Somente será aprovada emenda que proponha anulação de despesa mencionada nas alíneas do inciso II quando se referir à correção de erros ou omissões".

427 Art. 33, da Resolução n 1 , de 2006-CN.

$428 \mathrm{O}$ artigo 34 da Resolução $\mathrm{n}^{\circ} 1$, de 2006-CN, relaciona o que deve constar do Relatório da Receita, deixando claro que o documento refere-se exclusivamente às receitas: "Art. 34. O Relatório da Receita deverá conter: I - exame da conjuntura macroeconômica e do endividamento e seu impacto sobre as finanças públicas; II - análise da evolução da arrecadação das receitas e da sua estimativa no projeto, com ênfase na metodologia e nos parâmetros utilizados; III - avaliação, em separado, das receitas próprias das entidades da administração indireta, em especial as pertencentes às agências reguladoras; IV - demonstrativo das receitas reestimadas, comparando-as com as do projeto, classificadas por natureza e fonte; V- demonstrativo das propostas de pareceres às emendas à receita e de renúncia de receitas; VI o montante de eventuais recursos adicionais decorrentes da reestimativa das receitas, discriminando as variações positivas e negativas por natureza e fonte de recursos; VII - indicação dos montantes de despesa a serem reduzidos no Parecer Preliminar, quando necessário; VIII - a verificação do atendimento às normas constitucionais e legais pertinentes à Receita, especialmente quanto à compatibilidade do projeto com a lei do plano plurianual, a lei de diretrizes orçamentárias e a Lei Complementar $\mathrm{n}^{\circ}$ 101, de 2000. Parágrafo único. O Relatório da Receita não poderá propor o cancelamento, parcial ou total, de dotações constantes do projeto”. 
observadas no oferecimento de emendas e na elaboração do relatório por parte do RelatorGeral e dos Relatores Setoriais ${ }^{429}$.

O Relatório Preliminar é composto de duas partes: a geral e a especial. Na parte geral deverão ser contemplados, dentre outros assuntos, o exame das metas fiscais, a análise da compatibilidade com o PPA, a LDO e a Lei de Responsabilidade Fiscal, a apreciação das despesas por área temática e a programação orçamentária (em confronto com a execução do exercício anterior e o quanto autorizado na lei orçamentária em vigor). Já na parte especial do relatório deverão constar, dentre outros temas, as diretrizes para atuação dos Relatores Setoriais e do Relator-Geral e as instruções específicas para a apresentação e apreciação de emendas $^{430}$.

A partir da aprovação do Parecer Preliminar, inicia-se a fase de apresentação de emendas à despesa, as quais poderão ser encaminhadas por parlamentares, comissões permanentes do Senado e da Câmara dos Deputados e bancadas estaduais. As emendas podem ser de remanejamento, apropriação ou cancelamento.

A emenda de remanejamento é a que tem por finalidade a proposta de aumento ou inserção de dotações e, ao mesmo tempo, como origem de recursos, a anulação correspondente de dotações constantes do projeto, excetuadas as da Reserva de Contingência $^{431}$. A aprovação de tal emenda é condicionada à anulação das dotações indicadas nela própria, verificada a compatibilidade das fontes de recursos ${ }^{432}$.

A emenda de apropriação tem como proposta acrescer ou incluir dotações e, simultaneamente, como fonte de recursos, anular de forma equivalente recursos integrantes da Reserva de Recursos ${ }^{433}$ ou de outras dotações estabelecidas no Parecer Preliminar ${ }^{434}$.

\footnotetext{
Art. 51 da Resolução n 1 , de 2006-CN.

Artigo 52, da Resolução n ${ }^{\circ} 1$, de 2006-CN.

431 Artigo 38, caput, da Resolução n ${ }^{\circ}$ 1, de 2006-CN. A Reserva de Contingência, de acordo com Carlos Valder do Nascimento (Arts. $1^{\circ}$ a 17. In: MARTINS, Ives Gandra da Silva; NASCIMENTO, Carlos Valder do. Comentários à Lei de Responsabilidade Fiscal. São Paulo: Saraiva, 2001, p. 48), tem como finalidade "atender perdas que, conquanto sejam previsíveis, são episódicas, contingentes ou eventuais". Esclarece o autor que "são as instituídas para o atendimento do eventual ou imprevisto, em razão de projeções equivocadas das receitas. Constituem, assim, provisões ou fundos que possam suprir insuficiências das previsões feitas na lei orçamentária anual relativamente aos gastos assumidos pelo Poder Público. A forma de utilização e o montante das reservas de contingência serão fixados tendo como parâmetro a receita corrente líquida na lei de diretrizes orçamentárias” (Op. cit., p. 48).

432 Artigo $38, \S 1^{\circ}$, da Resolução ${ }^{\circ} 1$, de 2006-CN.

433 A Reserva de Recursos é "composta dos eventuais recursos provenientes da reestimativa das receitas, da Reserva de Contingência e outros definidos no Parecer Preliminar, deduzidos os recursos para atendimento de emendas individuais, de despesas obrigatórias e de outras despesas definidas naquele Parecer"; entretanto, não integram a base de cálculo da Reserva de Recursos aqueles "provenientes de
} 
As propostas tendentes apenas à redução das dotações contidas no projeto de lei orçamentária anual são denominadas emendas de cancelamento ${ }^{435}$.

A Constituição Federal, de forma expressa, prevê condições para a aprovação de emendas ao projeto de lei orçamentária:

Art. 166. (...)

$\S 3^{\circ}$ - As emendas ao projeto de lei do orçamento anual ou aos projetos que o modifiquem somente podem ser aprovadas caso:

I - sejam compatíveis com o plano plurianual e com a lei de diretrizes orçamentárias;

II - indiquem os recursos necessários, admitidos apenas os provenientes de anulação de despesa, excluídas as que incidam sobre:

a) dotações para pessoal e seus encargos;

b) serviço da dívida;

c) transferências tributárias constitucionais para Estados, Municípios e Distrito Federal; ou III - sejam relacionadas:

a) com a correção de erros ou omissões; ou

b) com os dispositivos do texto do projeto de lei. ${ }^{436}$

Além das condições acima mencionadas, existem limitações para a apresentação de emendas. As Comissões Permanentes do Senado Federal e da Câmara dos Deputados somente estão autorizadas a apresentar emendas em relação àquelas matérias referentes às suas áreas de atuação; mesmo assim, a quantidade de propostas é limitada ${ }^{437}$.

autorizações de cancelamentos seletivos contidas no Parecer Preliminar que dependam de avaliação posterior dos Relatores" (artigo 56, da Resolução n ${ }^{\circ}$, de 2006-CN).

As mesmas restrições foram contempladas no artigo 41 da Resolução ${ }^{\circ}{ }^{1}$, de 2006-CN: "Art. 41. A emenda ao projeto que propõe acréscimo ou inclusão de dotações, somente será aprovada caso: I - seja compatível com a lei do plano plurianual e com a lei de diretrizes orçamentárias; II - indique os recursos necessários, admitidos apenas os provenientes de anulação de despesas, excluídas as que incidam sobre: a) dotações para pessoal e seus encargos; b) serviço da dívida; c) transferências tributárias constitucionais para Estados, Municípios e Distrito Federal; III - não seja constituída de várias ações que devam ser objeto de emendas distintas; e IV - não contrarie as normas desta Resolução, bem como as previamente aprovadas pela CMO. Parágrafo único. Somente será aprovada emenda que proponha anulação de despesa mencionada nas alíneas do inciso II quando se referir à correção de erros ou omissões".

437 Nesse sentido, os artigos 44 e 45 da Resolução $n^{\circ}$ 1, de 2006-CN, estabelecem os parâmetros para a apresentação das emendas de Comissão, bem como os limites quantitativos: "Art. 44. As emendas de Comissão deverão: I - ser apresentadas juntamente com a ata da reunião que decidiu por sua apresentação; II - ter caráter institucional e representar interesse nacional, observado o disposto no art. 47, incisos II a V, vedada a destinação a entidades privadas, salvo se contemplarem programação constante do projeto; III - conter, na sua justificação, elementos, critérios e fórmulas que determinem a aplicação dos recursos, em função da população beneficiada pela respectiva política pública, quando se tratar de transferências voluntárias de interesse nacional. § $1^{\circ}$ Poderão ser apresentadas: I - até 4 (quatro) emendas, sendo 2 (duas) de apropriação e 2 (duas) de remanejamento, para as comissões cuja competência esteja restrita a uma única subárea temática, conforme definido no $\S 1^{\circ}$ do art. 26 desta Resolução, e observados os quantitativos constantes do Anexo a esta Resolução; II - até 8 (oito) emendas, sendo 4 (quatro) de apropriação e 4 (quatro) de remanejamento, para aquelas cuja competência abranja mais de uma subárea temática, observados os quantitativos constantes do Anexo a esta Resolução. $\S 2^{\circ}$ As Mesas Diretoras do Senado Federal e da Câmara dos Deputados poderão apresentar 
Da mesma forma, as bancadas estaduais podem apresentar emendas relativas a matérias de interesse dos respectivos estados (ou Distrito Federal, se for o caso) ${ }^{438}$, mas também em quantidades restritas ${ }^{439}$.

Aos parlamentares é igualmente permitida a apresentação de emendas individuais, limitadas a vinte e cinco, cabendo ao Parecer Preliminar estabelecer o valor total do conjunto de emendas a serem propostas ${ }^{440}$.

emendas, sendo até 4 (quatro) de apropriação e até 4 (quatro) de remanejamento. Art. 45. As emendas de remanejamento somente poderão propor acréscimos e cancelamentos em dotações de caráter institucional e de interesse nacional, no âmbito da mesma subárea temática e mesmo grupo de natureza de despesa, observada a compatibilidade das fontes de recursos".

Artigo 46, da Resolução n ${ }^{\circ}$, de 2006-CN.

439 As condições para a apresentação dessas emendas, bem como as limitações quantitativas estão previstas nos artigos 47 e 48 da Resolução n 1, de 2006-CN: "Art. 47. As emendas de Bancada Estadual deverão: I - ser apresentadas juntamente com a ata da reunião que decidiu por sua apresentação, aprovada por $3 / 4$ (três quartos) dos Deputados e 2/3 (dois terços) dos Senadores da respectiva Unidade da Federação; II identificar de forma precisa o seu objeto, vedada a designação genérica de programação que possa contemplar obras distintas ou possam resultar, na execução, em transferências voluntárias, convênios ou similares para mais de um ente federativo ou entidade privada; III - no caso de projetos, contemplar, alternativamente a: a) projeto de grande vulto, conforme definido na lei do plano plurianual; b) projeto estruturante, nos termos do Parecer Preliminar, especificando-se o seu objeto e a sua localização; IV - no caso de atividades ou operações especiais, restringir-se às modalidades de aplicação 30 (trinta - governo estadual ) e 90 (noventa - aplicação direta); V - em sua justificação, conter, no mínimo: a) os elementos necessários para avaliar a relação custo-benefício da ação pretendida e seus aspectos econômico-sociais; b) o valor total estimado, a execução orçamentária e física acumulada e o cronograma da execução a realizar, em caso de projeto; c) as demais fontes de financiamento da ação e as eventuais contrapartidas. $\S 1^{\circ}$ Poderão ser apresentadas no mínimo 15 (quinze) e no máximo 20 (vinte) emendas de apropriação, além de 3 (três) emendas de remanejamento, sendo que: I - as Bancadas Estaduais com mais de 11 (onze) parlamentares poderão apresentar, além do mínimo de 15 (quinze) emendas, uma emenda de apropriação para cada grupo completo de 10 (dez) parlamentares da bancada que exceder a 11 (onze) parlamentares; II - nas Bancadas Estaduais integradas por mais de 18 (dezoito) parlamentares, caberá à representação do Senado Federal a iniciativa da apresentação de 3 (três) emendas de apropriação dentre aquelas de que trata o caput. $\S 2^{\circ}$ Os projetos constantes de lei orçamentária anual, oriundos de aprovação de emendas de Bancada Estadual, uma vez iniciados, deverão ser, anualmente, objeto de emendas apresentadas pela mesma Bancada Estadual até a sua conclusão, salvo se: I - constem do projeto de lei orçamentária; ou II - a execução física não tiver alcançado $20 \%$ (vinte por cento) do total da obra; ou III - houver comprovado impedimento legal à continuidade da obra; ou IV - houver decisão em contrário da unanimidade da bancada. $\S 3^{\circ} \mathrm{Na}$ hipótese do descumprimento do disposto no $\S 2^{\circ}: \mathrm{I}-\mathrm{o}$ Comitê de Admissibilidade de Emendas proporá a inadmissibilidade de emendas de Bancada Estadual, em número equivalente àquelas que deixaram de ser apresentadas, a partir daquela com o menor valor proposto; II - o Relator-Geral substituirá a emenda de que trata o inciso I por emenda necessária à continuidade do projeto. Art. 48. As emendas de remanejamento somente poderão propor acréscimos e cancelamentos em dotaç̃oes no âmbito da respectiva Unidade da Federação, mesmo órgão e mesmo grupo de natureza de despesa, observada a compatibilidade das fontes de recursos".

440 Artigo 49, da Resolução n ${ }^{\circ} 1$, de 2006-CN. O artigo 50, da mesma Resolução, prevê as diretrizes para apresentação das emendas individuais dos parlamentares: "Art. 50. As emendas individuais: I - que destinarem recursos a entidades de direito público, deverão observar a programação passível de ser objeto de emendas, definida pelo Parecer Preliminar; II - que destinarem recursos a entidades privadas, deverão observar a programação passível de ser objeto de emendas, definida no Parecer Preliminar e, cumulativamente: a) atender às disposições contidas na lei de diretrizes orçamentárias; b) estipular as metas que a entidade beneficiária deverá cumprir, demonstrando a sua compatibilidade com o valor da emenda; c) identificar a entidade beneficiada, seu endereço e o nome dos responsáveis pela direção; III deverão, no caso de projetos, resultar, em seu conjunto, em dotação suficiente para conclusão da obra ou 
As emendas dos relatores somente são admitidas para a finalidade de sanar omissões ou corrigir erros de caráter técnico e legal, restabelecer dotações canceladas, bem como para seguir as orientações contidas no Parecer Preliminar ${ }^{441}$.

Findo o prazo para apresentação de emendas ao projeto de lei orçamentária, inicia-se o período para votação, pela CMO, de cada um dos Relatórios Setoriais referentes às dez áreas temáticas (infraestrutura; saúde; integração nacional e meio ambiente etc.). Os mencionados documentos são elaborados pelos respectivos Relatores Setoriais, os quais devem observar as diretrizes expostas no Parecer Preliminar e, ainda, observar os requisitos impostos no artigo 70 da Resolução n ${ }^{\circ} 1$, de 2006-CN ${ }^{442}$.

Aprovados os relatórios setoriais, caberá ao Relator-Geral consolidar as respectivas decisões em documento único, denominado Relatório Geral, que também deverá atentar aos parâmetros do artigo 70 da Resolução $n^{\circ}$ 1, de 2006-CN. Em seguida, o documento é submetido à aprovação no plenário da $\mathrm{CMO}^{443}$, que passa a se chamar Parecer da CMO.

O referido parecer é enviado à Secretaria-Geral da Mesa do Congresso Nacional, devendo ser apreciado e votado pelas duas Casas, em sessão conjunta. Terminada a votação, a matéria retorna à CMO para a redação final do projeto (ou do substitutivo aprovado de

da etapa do cronograma de execução a que se refere. Parágrafo único. O Parecer Preliminar especificará os elementos que deverão constar da justificativa das emendas individuais". Artigo 144 da Resolução n ${ }^{\circ}$, de 2006-CN.

442 Assim estabelece o mencionado dispositivo: "Art. 70. Os Relatores do projeto deverão, em seus relatórios: I - analisar: a) o atendimento das normas constitucionais e legais, especialmente quanto à compatibilidade do projeto com a lei do plano plurianual, a lei de diretrizes orçamentárias e a Lei Complementar $\mathrm{n}^{\circ} 101$, de 2000; b) a execução orçamentária recente, comparando-a com os valores constantes do projeto; c) os efeitos da aprovação dos créditos especiais e extraordinários aprovados ou em apreciação pelo Congresso nos últimos 4 (quatro) meses do exercício; d) os critérios utilizados nos cancelamentos e acréscimos efetuados na programação orçamentária e seus efeitos sobre a distribuição regional; e) as medidas adotadas em relação às informações enviadas pelo Tribunal de Contas da União quanto às obras e serviços com indícios de irregularidades graves, justificando sua inclusão ou manutenção; II - indicar, para votação em separado, os subtítulos que contenham contrato, convênio, parcela, trecho ou subtrecho em que foram identificados, de acordo com informações do Tribunal de Contas da União, indícios de irregularidades graves; III - apresentar demonstrativos: a) do voto do Relator às emendas individuais à despesa, por tipo de proposta de parecer e por autor, contendo, para cada um, o número da emenda, a classificação institucional, funcional e programática, a denominação do subtítulo, a decisão e o valor concedido; b) do voto do Relator às emendas coletivas à despesa, por tipo de proposta de parecer, unidade da Federação e autor, contendo, para cada um, o número da emenda, a classificação institucional, funcional e programática, a denominação do subtítulo, a decisão e o valor concedido; c) das emendas com proposta de parecer pela inadmissibilidade; IV - anexar os espelhos das emendas de Relator, acompanhados dos respectivos fundamentos técnicos e legais e do demonstrativo dessas emendas por modalidade".

443 De acordo com o artigo 77, da Resolução n ${ }^{\circ}$ 1, de 2006-CN, "na apreciação do relatório do RelatorGeral serão votadas, inicialmente, as emendas que proponham cancelamento parcial ou total de dotações constantes do projeto e, em seguida, as emendas destinadas a alterar o texto do projeto, ressalvados os destaques". A apresentação de destaques ao projeto e à emenda é disciplinada nos artigos 79 a 81, $138 \mathrm{e}$ 139 da Resolução n ${ }^{\circ}$, de 2006-CN. 
forma definitiva), recebendo o nome de Autógrafo. Após esse procedimento, o documento é encaminhado ao Presidente da República para sanção ou veto (parcial ou total); a parte sancionada é promulgada e publicada como lei no Diário Oficial da União. Termina, dessa forma, a fase legislativa da elaboração do orçamento anual.

\subsection{Os poderes conferidos ao Congresso Nacional na questão orçamentária e as circunstâncias incentivadoras ao desvio de recursos públicos}

A Constituição Federal de 1988 confere relevantes poderes ao Congresso Nacional em relação à definição do orçamento da União. Essa participação do Poder Legislativo, na verdade, é salutar e necessária na medida em que representa uma garantia para o povo, especialmente no tocante à sua liberdade.

Lembra-se que a Declaração de Direitos do Homem e do Cidadão, de 26 de agosto de 1789, na França, já propugnava que "todos os cidadãos têm direito de verificar, por si ou por meio de seus representantes, a necessidade da contribuição pública, de consenti-la livremente, de fiscalizar o seu emprego e de lhe fixar a alíquota, a base de cálculo, a cobrança e a duração" (artigo 14$)^{444}$.

O Legislativo, ao representar o povo na discussão do orçamento, tem como uma das funções não apenas garantir a liberdade, mas também evitar o estabelecimento de privilégios, os quais acabam por desagregar toda a sociedade, gerando inclusive a corrupção ${ }^{445}$.

444 Para um estudo aprofundado a respeito da Declaração de Direitos do Homem e do Cidadão, bem como das liberdades públicas, ver Manoel Gonçalves Ferreira Filho (Direitos humanos fundamentais. $5^{\mathrm{a}}$ ed. rev. São Paulo: Saraiva, 2002, pp. 19-37) e Fábio Konder Comparato (A afirmação histórica dos direitos humanos. $3^{\mathrm{a}}$ ed. rev. e ampl. São Paulo: Saraiva, 2003, pp. 124-162).

445 Emmanuel Sieyes (¿Qué es el Tercer Estado?: Precedido de Ensayo sobre los privilegios. Tradução de Marta Lorente Sariñena e Lidia Vázquez Jiménez. Madrid: Alianza Editorial, 2008, pp. 49, 50 e 52. Título original: Qu'est-ce que le Tiers-État? Essai sur les privilèges) analisa as consequências do privilégio na sociedade: "Tem-se afirmado que o privilégio é uma dispensa para aquele que o obtém e um desalento para os demais. Se é assim, deve-se reconhecer que os privilégios são uma triste invenção. Imaginemos uma sociedade construída e feliz. Não é evidente que para transtorná-la por completo bastará dispor a uns e desalentar os demais? [...]

Todos os privilégios, sem distinção, têm certamente por objeto dispensar da lei ou outorgar um direito exclusivo a algo que não está proibido pela lei. A essência do privilégio é sua existência fora do direito comum, que somente pode ser evitado por uma dessas duas maneiras. [...]

Da mesma forma, não se pode outorgar a uma pessoa o direito exclusivo a algo que não está proibido pela lei; significaria arrebatar dos cidadãos uma porção de sua liberdade. Já vimos que tudo que não está proibido pela lei é do domínio da liberdade civil e pertence a todos. Conceder a alguém um privilégio exclusivo sobre o que pertence a todo mundo seria prejudicar a todos em benefício de um só; o que se 
No Brasil, como se pôde depreender do item antecedente, no qual se demonstrou o procedimento de elaboração da lei orçamentária anual, o papel exercido pela Comissão Mista de Planos, Orçamentos Públicos e Fiscalização (CMO) revela a importância de ambas as Casas Legislativas (Câmara dos Deputados e Senado) no tocante ao direcionamento de recursos públicos do país.

José Maurício Conti ${ }^{446}$ assim resume os fatores que consagram a autoridade do Congresso Nacional no tocante ao orçamento:

O sistema orçamentário adotado pelo Brasil confere significativo poder e participação do Legislativo no processo de elaboração e execução dos orçamentos públicos, cabendo-lhe deliberar sobre a proposta orçamentária apresentada pelo Poder Executivo, podendo alterá-la na forma e limites previstos na Constituição e na legislação infraconstitucional, e sendo o responsável final pela aprovação do projeto, após votação no Plenário, em apreciação conjunta por ambas as Casas do Congresso Nacional. Cumpre destacar ainda as orientações que constam das leis de diretrizes orçamentárias e planos plurianuais, ambas aprovadas pelo Poder Legislativo e que estabelecem metas e diretrizes que condicionam a elaboração da lei orçamentária anual.

A configuração desse poder pode ser percebida, igualmente, no tocante à possibilidade de o Poder Legislativo exercer influência relevante na destinação de valores vultosos, como são aqueles objeto do orçamento federal. A título de exemplo da grandeza das quantias envolvidas, tome-se como subsídio o orçamento da União para $2010^{447}$, em que as receitas do governo foram estimadas em $\mathrm{R} \$ 1,856$ trilhão. Desse total, descontados os valores para pagamento dos juros da dívida (R \$ 596,2 bilhões), bem como os recursos

assemelha à injustiça e à mais absurda irracionalidade. Todos os privilégios são, pois, por natureza, injustos, odiosos e contraditórios com o fim supremo de toda a sociedade política".

Tradução livre do autor. No original: "Se ha dicho que el privilegio es una dispensa para el que lo obtiene y un desaliento para los demás. Si ello es así, habrá que reconocer que los privilegios son una triste invención. Imaginemos una sociedad construida y feliz. ¿No es evidente que para trastornarla por completo bastará com disponer a unos y desalentar a los demás? [...]

Todos los privilegios, sin distinción, tienen ciertamente por objeto dispensar de la ley u otorgar un derecho exclusivo a algo que no está prohibido por la ley. La esencia del privilegio es su existencia fuera del derecho común, que sólo puede ser eludido de una u otra de esas dos maneras. [...]

Asimismo, no puede otorgarse a una persona el derecho exclusivo a algo que no está prohibido por la ley; ello supondría arrebatar a los ciudadanos una porción de su libertad. Ya hemos visto que todo lo que no está prohibido por la ley es del dominio de la libertad civil y pertenece a todo el mundo. Conceder a alguien un privilegio exclusivo sobre lo que pertenece a todo el mundo sería perjudicar a todos en beneficio de uno solo; lo cual supone la imagen misma de la injusticia y la más absurda sinrazón. Todos los privilegios son, pues, por naturaleza, injustos, odiosos y contradictorios con el fin supremo de toda sociedad política".

Ainda sobre a questão dos privilégios e do tratamento desigual, ver Ricardo Lobo Torres (Tratado de direito constitucional financeiro e tributário: os direitos humanos e a tributação: imunidades $e$ isonomia. $3^{\mathrm{a}}$ ed., rev. e atual. Rio de Janeiro: Renovar, 2005, v. 3, pp. 339-500).

446 Da elaboração da Lei de Orçamento. In: CONTI, José Mauricio (coord.). Orçamentos públicos: a Lei 4.320/1964 comentada. São Paulo: Editora Revista dos Tribunais, 2008, p. 119.

447 Aprovado pelo Plenário do Congresso Nacional em 22 de dezembro de 2009, mas ainda pendente de sanção do Presidente da República. 
referentes a investimentos das empresas estatais ( $\mathrm{R}$ \$ 94,4 bilhões), o orçamento efetivo ainda representa a significativa importância de $\mathrm{R} \$ 1,26$ trilhão $^{448}$.

O problema é que todo o trâmite legislativo para aprovação do orçamento anual é por demais técnico e complexo, o que dificulta um controle rígido sobre tais procedimentos, bem como impede um maior envolvimento da população, seja na fiscalização do processo mencionado, seja na participação efetiva para interferir e propor alterações no projeto de lei orçamentária.

As citadas dificuldades, aliadas à magnitude dos valores que representam o orçamento, atraem incentivos à prática de condutas clientelistas, patrimonialistas, caçadoras de rendas (rent-seeking), bem como atos de corrupção ${ }^{449}$. A situação transparece mais evidente quando se analisa a situação de dependência vivenciada pelos entes subnacionais, os quais se sentem estimulados a alimentar a lógica clientelista e patrimonialista em busca de maiores recursos oriundos do orçamento federal.

Verifica-se que, no caso brasileiro, o intrincado percurso legislativo para aprovação da peça orçamentária anual, antes de se configurar garantia de liberdade ao povo, representa, na verdade, um risco à integridade dos recursos públicos, pois encoraja atos de desvio. Em última análise, esse dano resvala na própria sociedade, que seria a beneficiária desses recursos, mas se vê impedida de utilizá-los de forma completa e eficaz.

4.5.1 A apresentação de emendas à proposta da lei orçamentária anual, o pork-barrel e a impossibilidade de se alcançar o interesse nacional

Dentre os poderes conferidos ao Congresso Nacional em relação à proposta de lei orçamentária anual, um dos mais relevantes se refere à possibilidade de apresentação de emendas ao projeto.

De acordo com Celina Souza, esse poder entregue ao Legislativo é fruto da inexistência, no federalismo brasileiro, de um mecanismo eficaz de regras formais para

\footnotetext{
448 Aprovado Orçamento de R\$ 1,86 trilhão em 2010. Jornal do Senado, ano XV, $\mathrm{n}^{\circ}$ 3.163, Brasília, 23/12/2009, p. 2.

449 William Dorotisnsky e Shilpa Pradhan (Exploring Corruption in Public Financial Management. In: CAMPOS, J. Edgardo e PRADHAN, Sanjay (edit.). The many faces of corruption: tracking vulnerabilities at the sector level. Washington: The World Bank, 2007, p. 267-294) também relatam a existência de corrupção durante o processo orçamentário americano. Sua ocorrência é influenciada por fatores como divisão de poderes entre Legislativo e Executivo, o sistema eleitoral, a ausência de transparência do processo orçamentário etc. Tais fatores também serão abordados no caso brasileiro.
} 
proporcionar o equilíbrio fiscal entre os entes federados, o que provoca a criação de espaços para o surgimento e emprego de regras informais ${ }^{450}$.

Entende-se por regras formais aquelas "que distribuem os recursos públicos nacionais por determinação constitucional ou legal, tais como os fundos de participação dos estados e municípios", enquanto que as regras informais, "embora também promovam distribuição das receitas públicas, não o fazem a partir de critérios determinados para tal fim, tais como as emendas ao orçamento" ${ }^{451}$. Em outras federações como Suíça, Alemanha, Austrália e Canadá, em que existem mecanismos de equalização fiscal mais eficientes, é rara a presença de regras para emendas ao orçamento ${ }^{452}$.

As emendas configuram, assim, regras informais utilizadas com o intuito de proporcionar o equilíbrio fiscal da federação e de solucionar conflitos provocados em razão das desigualdades regionais ${ }^{453}$; seu emprego estimula o surgimento de relações dos mais diversos níveis e agentes diante do interesse existente na alocação dos recursos orçamentários.

A previsão de emendas ao projeto de lei orçamentária anual, por si só, não deveria provocar efeitos nocivos à federação, uma vez que representa a possibilidade de o Poder Legislativo contemplar os anseios e necessidades de estados e municípios por intermédio da

450 Federalismo e Conflitos Distributivos: Disputa dos Estados por Recursos Orçamentários Federais. In: Dados - Revista de Ciências Sociais. Rio de Janeiro, v. 46, n 2, 2003, pp. 346-347. Também disponível em http://www.scielo.br/pdf/dados/v46n2/a06v46n2.pdf, acessado em: 02.12.2008.

451 Celina Souza. Federalismo e Conflitos Distributivos: Disputa dos Estados por Recursos Orçamentários Federais. In: Dados - Revista de Ciências Sociais. Rio de Janeiro, v. 46, n 2, 2003, p. 378, nota $n^{\circ} 1$. Também disponível em http://www.scielo.br/pdf/dados/v46n2/a06v46n2.pdf, acessado em 02.12.2008.

452 Celina Souza. Federalismo e Conflitos Distributivos: Disputa dos Estados por Recursos Orçamentários Federais. In: Dados - Revista de Ciências Sociais. Rio de Janeiro, v. 46, n 2, 2003, p. 378, nota $n^{\circ} 2$. Também disponível em http://www.scielo.br/pdf/dados/v46n2/a06v46n2.pdf, acessado em 02.12.2008.

453 Deve-se atentar, porém, que as emendas à proposta orçamentária não são as únicas regras informais presentes no federalismo fiscal brasileiro. Outras fontes informais também se apresentam. Esse é o entendimento de Celina Souza (Federalismo e Conflitos Distributivos: Disputa dos Estados por Recursos Orçamentários Federais. In: Dados - Revista de Ciências Sociais. Rio de Janeiro, v. 46, n 2, 2003 , p. 355. Também disponível em http://www.scielo.br/pdf/dados/v46n2/a06v46n2.pdf, acessado em 02.12.2008): "Evidentemente, a CMO não é a única forma de negociação entre Executivo, Legislativo, governadores e prefeitos. Outras, tão ou mais importantes, se sobressaem, tais como: a) nomeações para cargos na burocracia federal e agências estatais e paraestatais, como os fundos de pensão; b) aprovação de pedidos de financiamento de estados e municípios a ser autorizada pelo Senado; c) renegociação de dívidas dos estados e de grandes municípios com a União; d) inclusão, ao término do exercício financeiro, de emendas de parlamentares ligados ao governo que dizem respeito a créditos suplementares encaminhados pelo Executivo ao Congresso; e) apoio financeiro federal, por intermédio de incentivos, subvenções e financiamentos a juros subsidiados, oferecido por organismos federais como Caixa Econômica Federal - CEF, Banco do Brasil - BB, bancos federais de desenvolvimento regional e Banco Nacional de Desenvolvimento Econômico e Social - BNDES; e f) vantagens financeiras para estados e regiões em outras comissões do Congresso, de que é exemplo a lei de incentivos fiscais para a instalação de montadoras no Norte, Nordeste e Centro-Oeste promulgada em 1997 e reeditada em 1999”. 
alocação de recursos públicos e da consequente disponibilização de bens e serviços a esses entes, caracterizando, dessa forma, um instrumento de combate aos desequilíbrios regional e local.

O problema é que, por mais das vezes, as emendas individuais dos parlamentares e das bancadas estaduais não têm como finalidade projetos voltados para o interesse público nacional. Os recursos acabam sendo aplicados de forma ineficiente, uma vez que direcionados para benefício de determinados locais ou regiões (não alcançando qualquer escopo nacional), com o objetivo de obter vantagens políticas. É a denominada política do pork-barrel (em sentido literal, "barril com carne de porco"454).

A ocorrência do fenômeno também é comum nos Estados Unidos, onde o termo é utilizado para designar a hipótese em que a legislação autoriza a dotação para obras públicas em regiões nas quais a demanda não se justificaria ${ }^{455}$. Isso levou Robert M. Stein e Kenneth N. Bickers a afirmarem ser "uma crença persistente na política norte-americana que os legisladores que 'trazem para casa o bacon' são recompensados por seus esforços nas

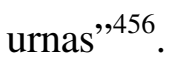

O pork-barrel designa, dessa forma, a alocação de bens e serviços públicos a determinados locais ou regiões, com o objetivo de angariar dividendos políticos provenientes dessas localidades. Os custos da referida alocação, no entanto, são repartidos entre toda a sociedade.

Não por acaso, a expressão também é traduzida, em algumas situações, como clientelismo ou fisiologismo. A ideia de clientelismo já foi explicitada no item 2.3.2 do presente estudo. Entende-se por fisiologismo a prática orientada para o proveito próprio ou

454 O termo era utilizado para descrever a prática de entregar aos escravos americanos, como recompensa, um barril com carne de porco salgada. O alimento era, então, disputado pelos escravos, que consideravam a atitude do senhor um ato de bondade.

455 J. Roland Pennock. The "pork barrel" and majority rule: a note. In: The Journal of Politics, Cambridge University Press/Southern Political Science Association, v. 32, $\mathrm{n}^{\circ}$ 3, ago. 1970, p. 709; também disponível em http://www.jstor.org/stable/2128838, acessado em 03.01.2010. No original: “The term 'pork barrel', as applied to legislation that makes or authorizes appropriation for public works in many districts of the country in excess of what a rational apportionment of resources to needs would justify, appears to have originated in the United States. That the phenomenon itself is American in origin is doubtful, but that it is specially characteristic of the United States is at least widely accepted as a fact".

456 Congressional Elections and the Pork Barrel. In: The Journal of Politics, Cambridge University Press/Southern Political Science Association, v. 56, n 2, mai. 1994, p. 377. Também disponível em http://www.jstor.org/stable/2132144, acessado em 03.01.2010. Tradução livre do autor. No original: "It is an enduring belief in American politics that legislators who 'bring home the bacon' are rewarded for their efforts at the ballot box". 
de partido político, desvinculada do interesse público, podendo ser realizada inclusive por meio de atos de corrupção.

A prática do pork-barrel, conquanto se admita que favoreça atos de corrupção e estimule o surgimento do patrimonialismo, do clientelismo e outras formas de desvio de recursos públicos, não representa, por si só, nenhuma ilegalidade praticada pelo parlamentar. $\mathrm{Na}$ verdade, diante da forma como a aprovação das emendas é estruturada no âmbito da CMO, não há que se ter pressa em censurar o ato de deputados e senadores, os quais não encontram incentivos para atuarem de modo diverso. Nesse sentido, Celina Souza ${ }^{457}$ explica que,

Na lógica da teoria da escolha racional, o pork barrel gera o paradoxo da cooperação, já que provê unicamente a área ou região que recebe esses recursos, a expensas de todos os contribuintes. Na verdade, os congressistas lucrariam se não houvesse pork. Apesar de cada parlamentar ter um forte incentivo para continuar a querer proteger seu distrito, eles sabem que todos se beneficiariam igualmente sem o pork, mas mesmo assim continuam insistindo. Nesse caso, o 'dividendo cooperativo' resultante da ausência de pork, em que um distrito perde seu projeto mas é recompensado por não ter que financiar projetos em outros, não é estável porque os políticos continuam a ter incentivos para viabilizar iniciativas para seus estados e distritos. ${ }^{458}$

Diante da inexistência de incentivos para agirem de modo diverso, deputados e senadores não se arriscam a deixar de propor emendas para beneficiar localidades que inclusive os elegeram; eles se veem impedidos de adotar postura diferente diante do círculo vicioso mencionado. Nesse caso, a ausência de regras formais e eficientes de equalização fiscal ainda constrange à busca de emendas ao orçamento federal, prejudicando, ao final, o interesse nacional.

Tal comportamento acaba gerando um fenômeno denominado pela Economia e também pela Teoria dos Jogos como "tragédia dos comuns", que é o resultado obtido diante do conflito entre o interesse individual e o bem comum na busca de recursos escassos. Em razão da inexistência de medidas que impeçam o livre acesso a um determinado recurso

457 Federalismo e Conflitos Distributivos: Disputa dos Estados por Recursos Orçamentários Federais. In: Dados - Revista de Ciências Sociais. Rio de Janeiro, v. 46, n 2, 2003, p. 353. Também disponível em http://www.scielo.br/pdf/dados/v46n2/a06v46n2.pdf, acessado em 02.12.2008.

458 A mesma autora (Federalismo e Conflitos Distributivos: Disputa dos Estados por Recursos Orçamentários Federais. In: Dados - Revista de Ciências Sociais. Rio de Janeiro, v. 46, n ${ }^{\circ}$ 2, 2003, p. 368. Também disponível em http://www.scielo.br/pdf/dados/v46n2/a06v46n2.pdf, acessado em 02.12.2008) declara, porém, que nos últimos tempos as ações individualizadas de parlamentares sofreram diminuições em razão das alterações de procedimentos na $\mathrm{CMO}$, que passou a privilegiar as emendas de bancada em detrimento das individuais, incentivando ações mais cooperativas. Apesar dessas considerações da autora, entende-se, contudo, que a lógica clientelista e patrimonialista continua impregnada na proposição e aprovação dessas emendas, ainda que sejam originadas de bancada. 
finito, este acaba sofrendo uma demasiada exploração, diante da busca de maximização dos ganhos individuais, comprometendo a existência do próprio recurso e prejudicando o interesse de todos; daí o termo "tragédia dos comuns" "459.

O resultado se agrava quando os recursos destinados a estados ou municípios são insuficientes para o término das obras ou dos serviços públicos, provocando, também, ineficiência na alocação dos gastos públicos ${ }^{460}$.

Deve-se ressaltar que, na verdade, apenas uma pequena fração do orçamento total pode ser objeto de emenda dos parlamentares. Ocorre que é justamente essa pequena parcela de recursos que alimenta a estrutura patrimonialista e clientelista existente entre o governo central e os entes subnacionais, favorecendo inclusive a ocorrência de atos de corrupção.

As emendas ao orçamento servem, como se verá adiante, como instrumento de manipulação do governo federal para fazer valer propostas de sua autoria encaminhadas ao Congresso Nacional. Em outras palavras, as mencionadas emendas, longe de representarem o interesse público, acabam servindo de dispositivo para concentrar maior domínio em mãos do poder central e favorecer interesses regionalizados, desestruturando toda a lógica do federalismo fiscal.

O advento de uma maior descentralização em todas as suas dimensões, conforme tratado no capítulo anterior, facilitaria e permitiria a utilização de mecanismos eficazes de equilíbrio físcal sem abrir margem ao desvio de recursos públicos, dispensando-se a previsão de emendas ao orçamento. A necessidade dessa maior descentralização pode ser depreendida das seguintes observações de Marcos Otávio Bezerra ${ }^{461}$ :

As emendas que têm por objetivo o desenvolvimento de programas nos estados e municípios aos quais os parlamentares estão politicamente vinculados são designadas comumente como

459 Sobre a "tragédia dos comuns" e a Teoria dos Jogos, ver Ronaldo Fiani (Teoria dos Jogos: com aplicações em Economia, Administração e Ciências Sociais. 2a ed. rev. e atual. Rio de Janeiro: Elsevier, 2006); José Augusto Moreira de Carvalho (Introdução à Teoria dos Jogos no Direito. In: Revista de Direito Constitucional e Internacional. Ano 15, n. 59, abr-jun de 2007, São Paulo, Editora Revista dos Tribunais/Instituto Brasileiro de Direito Constitucional - IBDC, pp. 213-234); Armando Castelar Pinheiro e Jairo Saddi (Direito, Economia e Mercados. Rio de Janeiro: Elsevier, 2005, pp. 157-200); Robert S. Pindyck e Daniel L. Rubinfeld (Microeconomia. Tradução de Eleutério Prado. 5a ed. São Paulo: Prentice Hall, 2002, pp. 461-501. Título original: Microeconomics).

460 Nesse sentido, Marcos Otávio Bezerra (Em nome das "bases": política, favor e dependência pessoal. Rio de Janeiro: Relume Dumará/Núcleo de Antropologia da Política, 1999, p. 72) afirma que "a inserção de emendas paroquiais [destinadas a estados e municípios, com pouco interesse nacional] na lei orçamentária tem sido responsável pelo que se designa como pulverização dos recursos públicos, ou seja, a distribuição, por inúmeras obras, de parcelas de recursos muitas vezes insuficientes para a conclusão dos projetos".

461 Em nome das "bases": política, favor e dependência pessoal. Rio de Janeiro: Relume Dumará/Núcleo de Antropologia da Política, 1999, p. 70. 
emendas paroquiais. $\mathrm{O}$ termo tem um sentido pejorativo, é utilizado em comparação com as emendas voltadas para as questões tidas como mais amplas e remete à preocupação dos parlamentares com a destinação de recursos para suas bases eleitorais. Se esse tipo de emenda é tida como paroquial, os parlamentares que as elaboram não raras vezes são rotulados como vereadores federais e o orçamento da União, por conseguinte, devido à natureza dos projetos aprovados ('pequenos projetos'), é comparado com os orçamentos Municipais. A aproximação do poder federal do poder municipal é fundada na constatação de uma certa continuidade nas práticas políticas relacionadas à elaboração do orçamento nessas duas dimensões do poder público. A obtenção de recursos (federal, estadual ou municipal) para o atendimento de demandas particularísticas, ou seja, de recursos que são dirigidos para as localidades às quais os políticos são vinculados parece ser uma preocupação presente em distintas instâncias políticas e, neste sentido, um elemento significativo da atividade política. $^{462}$

Como é possível deduzir a partir do texto acima, o locus da decisão sobre recursos destinados aos entes subnacionais é concentrado no orçamento da União, mais especificamente no âmbito da $\mathrm{CMO}$, atuando os parlamentares como representantes de interesses locais ou regionais, quando deveriam se preocupar com as necessidades gerais da nação, até mesmo para manter íntegra a federação. A transferência desse locus para os respectivos entes subnacionais, por outro lado, permitiria uma melhor atuação dos parlamentares, os quais poderiam, assim, se voltar aos interesses de toda a federação.

Enquanto não for possível o aparelhamento de uma nova estrutura à descentralização no federalismo brasileiro, a utilização de regras informais, como são exemplos as emendas orçamentárias, necessita de maior transparência, clareza, objetividade e acesso à população, a fim de que esta participe ativamente na sua elaboração. Evitar-se-ia, assim, a utilização

462 O problema do desvirtuamento do orçamento público federal e do objeto das emendas apresentadas pelos parlamentares é aprofundado pelo mesmo autor (Em nome das "bases": política, favor e dependência pessoal. Rio de Janeiro: Relume Dumará/Núcleo de Antropologia da Política, 1999, p. 72) ao esclarecer: "A questão da pulverização é colocada também em termos da natureza das obras que são realizadas com esses recursos. Observe-se, por exemplo, o comentário realizado pelo senador Epitácio Cafeteira (em aparte ao discurso pronunciado pelo senador Aluízio Bezerra): 'O que desfigura o orçamento e até a participação do Congresso na sua confecção é a pulverização das verbas para obras que nada têm a ver com o Governo Federal. (...) Se vamos discutir o orçamento federal para obras puramente estaduais ou municipais, vamos desfalcar esse país' (Aluízio Bezerra, Críticas ao Orçamento da União, 26/03/93, p. 7).

As verbas, portanto, estariam sendo destinadas para obras que seriam de atribuição estadual ou municipal. A concepção de que a participação do Congresso é responsável pela pulverização dos recursos orçamentários é partilhada, sobretudo, por técnicos do Poder Executivo ligados ao orçamento. $\mathrm{O}$ termo funciona como uma categoria acusatória e aponta para a natureza da intervenção dos parlamentares no orçamento. De fato, uma tensão permanente pauta a relação entre os integrantes dos dois poderes. Do lado dos órgãos ministeriais, domina o interesse de que seus programas de trabalho não sejam objeto de emendas parlamentares que especifiquem a aplicação dos recursos, isto é, sejam carimbados - só possam ser destinados a um município ou região específica. Ao contrário, é a oportunidade para destinar verbas para obras e investimentos nos estados e regiões de seu interesse que atrai parte dos parlamentares para participar da elaboração do orçamento". 
política dos recursos, facilitando o controle social e permitindo o exercício pleno da cidadania.

\subsubsection{As emendas ao orçamento e a relação dos parlamentares com suas bases eleitorais}

Estudou-se no item anterior que, apesar de os parlamentares possuírem consciência de que o pork-barrel é prejudicial à federação, não possuem incentivos para atuar de modo diverso. O dilema enfrentado por deputados e senadores pode ser explicado diante das pressões exercidas pelas suas respectivas bases eleitorais ${ }^{463}$, o que faz com que, na questão das emendas ao orçamento, o interesse local ganhe relevância maior. De fato, "como se crê que são os pleitos que trazem os votos, do ponto de vista eleitoral, por conseguinte, as ações dirigidas para as bases [eleitorais] são tidas freqüentemente como algo mais importante do que as que têm como motivação as questões nacionais" ${ }^{464}$.

Regis Fernandes de Oliveira ${ }^{465}$, ao criticar a concessão de subvenções sociais (transferências para fazer frente às despesas de custeio de "instituições públicas ou privadas de caráter assistencial, ou cultural, sem finalidade lucrativa” ${ }^{\natural 66}$ ) por intermédio de emendas ao orçamento, ressalta o esforço empreendido pelas bases eleitorais sobre os parlamentares e a perpetuação da lógica clientelista:

Em verdade, há um acordo partidário que permite que cada deputado insira no teor do orçamento anual verbas destinadas a sua base eleitoral. Tal situação é absurda. Em primeiro lugar, beneficia o local em que é votado o deputado, o que discrimina outros, que não tiveram o privilégio de eleger um parlamentar. É odiosa, porque ajuda a reeleição de deputados e senadores que, sendo assim, ficam em posição de superioridade em relação a outros possíveis candidatos. Nada, eticamente, ampara tal providência anual ocorrida no Congresso Nacional.

Tal providência, inclusive, leva à dependência dos parlamentares da base do governo à liberação posterior das verbas. Dependendo da matéria em votação, haverá ou não a liberação ministerial dos recursos, o que redundará no voto favorável do parlamentar à pretensão do governo.

463 De acordo com Marcos Otávio Bezerra (Em nome das "bases": política, favor e dependência pessoal. Rio de Janeiro: Relume Dumará/Núcleo de Antropologia da Política, 1999, p. 102), a definição de base eleitoral é ampla, não podendo ser sempre confundida com região geográfica de origem do parlamentar: "Um primeiro aspecto que chama a atenção é a mobilidade da categoria base eleitoral. Ela não remete a uma realidade fixa, mas a diferentes referentes: uma rua, um bairro ou uma cidade. A base é definida ora pelo local de residência, ora pelas relações sociais que o político mantém nas localidades. Neste sentido, e este é outro aspecto, ela não delimita simplesmente uma unidade geográfica ou administrativa, apesar do conceito de lugar ser fundamental para a definição da noção de base eleitoral, mas, sobretudo, um espaço de relações sociais".

464 Marcos Otávio Bezerra. Em nome das "bases": política, favor e dependência pessoal. Rio de Janeiro: Relume Dumará/Núcleo de Antropologia da Política, 1999, p. 117.

465 Curso de direito financeiro. São Paulo: Editora Revista dos Tribunais, 2006, p. 378.

466 Artigo 12, § $3^{\circ}$, inciso I, da Lei 4.320/1964. 
Nada justifica este estado de coisas, cabendo à sociedade repudiar tal comportamento. O problema que ocorre é a pressão da base eleitoral para a liberação de recursos. Se o deputado não conseguir verbas para os Municípios que nele votaram, o parlamentar 'não presta', 'não tem força', e passa a ser desprestigiado.

Deve-se afirmar que é legítimo o direito de os parlamentares buscarem formas de beneficiar sua base eleitoral. Aliás, o artigo 226, inciso V, do Regimento Interno da Câmara dos Deputados ${ }^{467}$ lhes assegura o direito de "promover, perante quaisquer autoridades, entidades ou órgãos da administração federal, estadual ou municipal, direta ou indireta e fundacional, os interesses públicos ou reivindicações coletivas de âmbito nacional ou das comunidades representadas" (destaque inserido). O problema ocorre quando o esforço parlamentar se concentra em beneficiar os interesses das bases eleitorais em prejuízo do interesse nacional $^{468}$.

A respeito da atuação parlamentar, Marcos Otávio Bezerra argumenta que ela ocorre, basicamente, sob duas bases: a) as atividades inerentes à função legislativa; e b) as atividades dirigidas às bases eleitorais. A primeira ação é inerente e comum à atuação parlamentar, pois se refere à possibilidade de o deputado ou senador bem atuar para fazer valer suas proposições nas respectivas Casas Legislativas, bem como deliberar, participar de reuniões de comissões, de sessões legislativas etc. Já as ações direcionadas às bases eleitorais são mais complexas e abrangentes, pois envolvem não apenas as ações voltadas à obtenção de recursos federais a estados e municípios, como também o atendimento a solicitações particulares de comunidades e eleitores, este último envolvendo comumente a mediação do parlamentar junto a setores governamentais ${ }^{469}$.

Dentre as atividades concentradas no atendimento às bases eleitorais, pode-se destacar a relação entre os parlamentares e as lideranças políticas locais, ou seja,

467 Resolução ${ }^{\circ} 17$, de 1989.

468 Marcos Otávio Bezerra (Em nome das "bases": política, favor e dependência pessoal. Rio de Janeiro: Relume Dumará/Núcleo de Antropologia da Política, 1999, p. 109) exemplifica como o atendimento aos pleitos das bases eleitorais consome o tempo dos parlamentares: "A importância atribuída aos pleitos como elemento de desempenho da função parlamentar e instrumento de manutenção de vínculo com as bases eleitorais expressa-se, por exemplo, no fato de gabinetes possuírem funcionários encarregados exclusivamente do cuidado desses pedidos. Recebê-los, cadastrá-los, tomar as providências para que sejam atendidos se for o caso, manter contato com o solicitante, são algumas das tarefas de que se ocupam. Em alguns gabinetes, como informou o assessor de um senador a partir de uma estimativa impressionista, o trabalho em torno dos pleitos corresponde a 50\% de suas atividades. Em dois gabinetes de senadores - ambos líderes partidários - tive informações a respeito do número de pleitos registrados no momento. No primeiro, o assessor falou em 86 e, no segundo, cadastrado em nove meses, constavam cerca de 450 pleitos".

469 Em nome das "bases": política, favor e dependência pessoal. Rio de Janeiro: Relume Dumará/Núcleo de Antropologia da Política, 1999, pp. 38-39. 
governadores, prefeitos e demais autoridades (vereadores e deputados estaduais, por exemplo).

A respeito dos mencionados agentes, não somente as emendas ao orçamento constituem importante elo nesse relacionamento, mas também a liberação dos valores previstos nas emendas, ou seja, o momento da execução orçamentária, em que os parlamentares trabalham junto aos órgãos ministeriais do Poder Executivo para a disponibilização dos recursos aprovados naquelas emendas.

Outro fator que favorece a aproximação entre as bases eleitorais e os parlamentares é a possibilidade de esses últimos influírem na proposta de lei orçamentária a ser apresentada pelo Poder Executivo. Vale dizer, antes mesmo das negociações no âmbito do Congresso Nacional, alguns deputados e senadores tentam incluir seus projetos nos planejamentos elaborados pelos ministérios e demais órgãos federais, o que já representaria uma vantagem considerável em relação aos demais parlamentares, que teriam que aguardar a fase das emendas individuais ou de bancada ${ }^{470}$.

A vinculação entre parlamentares e as lideranças locais é alimentada, no entanto, mediante a troca de favores ${ }^{471}$, o apoio político das autoridades governamentais (prefeitos e governadores) $)^{472}$ e os votos da base eleitoral, influenciando decisivamente no incentivo à

470 De acordo com Carlos Pereira e Bernardo Mueller (Comportamento estratégico em presidencialismo de coalizão: as relações entre Executivo e Legislativo na elaboração do orçamento brasileiro. In: Dados Revista de Ciências Sociais, Rio de Janeiro, v. 45, $\mathrm{n}^{\circ}$ 2, 2002, p. 269. Também disponível em http://www.scielo.br/scielo.php?script=sci_arttext\&pid=S0011-52582002000200004\&lng=en\&nrm=iso, acessado em 05.01.2010), "esses parlamentares saltam um estágio importante das negociações no Congresso, fazendo constar seus pedidos já no projeto enviado pelo presidente da República. É nessa fase que se dão as negociações mais ardilosas dentro do Poder Executivo, com cada parte buscando alargar seu quinhão do orçamento e o Tesouro procurando conter as reivindicações de todos".

471 Marcos Otávio Bezerra (Em nome das "bases": política, favor e dependência pessoal. Rio de Janeiro: Relume Dumará/Núcleo de Antropologia da Política, 1999, p. 135) exemplifica essa situação: "A troca de favores e serviços entre parlamentares e prefeitos pode incluir o pedido do parlamentar para que uma pessoa de suas relações ocupe um cargo na administração municipal. Além de chamar a atenção para a intervenção do parlamentar na administração municipal, estes casos apontam para o fato de que os pedidos de favores e serviços seguem nas duas direções, ou seja, dos prefeitos para os parlamentares e vice-versa. Como no caso do encaminhamento dos pleitos pelo parlamentar junto à burocracia federal, indicar uma pessoa para ocupar um cargo municipal é uma forma do parlamentar amarrar - o termo expressa em termos nativos a relação de dependência pessoal instituída - essa pessoa e integrantes de sua rede de relações".

$472 \mathrm{O}$ apoio político de prefeitos e governadores de algumas regiões do país denota claramente a existência de vínculos clientelistas e até coronelistas. Essa situação fica evidente no exemplo descrito por Marcos Otávio Bezerra (Em nome das "bases": política, favor e dependência pessoal. Rio de Janeiro: Relume Dumará/Núcleo de Antropologia da Política, 1999, p. 133): "Para o parlamentar, o poder do prefeito resulta, entre outros aspectos, do controle sobre a administração municipal e de seu prestígio político no município, isto é, em última instância, do apoio que é capaz de lhe proporcionar através da mobilização dos membros locais de suas redes políticas e de seus pedidos de votos para o candidato. Este poder está associado, entre outros aspectos, ao controle que a gestão da prefeitura lhe assegura de distribuição dos benefícios e recursos públicos locais. Como informa o mesmo senador (PMDB-PB): 'A grande força 
permanência de conexões clientelísticas e patrimonialistas (algumas vezes aproximando-se de relações do tipo coronelista) no âmbito da federação. O encorajamento à prática de atos de corrupção também é uma consequência dessa situação.

A destinação das verbas oriundas das emendas parlamentares ocorre, dessa forma, não por intermédio de um vínculo político programático ${ }^{473}$, mas da relação de compromisso existente com as bases eleitorais, em que o interesse público, na maioria das vezes, não é a preocupação primeira.

\subsubsection{A prática do lobby no processo de emendas ao orçamento e o interesse das empreiteiras}

É no momento anterior à apresentação de emendas ao orçamento, bem como na fase de liberação dos respectivos recursos que surge a atuação de pessoas ou de um grupo organizado com a finalidade de fazer valer seus interesses, qual seja, o direcionamento de recursos orçamentários.

Trata-se do lobby, termo inglês que possui o significado literal de "vestíbulo", "salão"; como verbo, possui o sentido de persuadir políticos para mudança de leis ${ }^{474}$. A expressão teve como origem o parlamento inglês, onde havia um vasto salão aberto ao público e utilizado para as audiências com os Membros do Parlamento.

A atividade expandiu-se, no entanto, nos Estados Unidos, onde é inclusive regulamentada desde 1946. De acordo com Paulo Sandroni, “empresas, grupos econômicos,

nessas regiões [no nordeste] é o governo, a prefeitura. Quem está na prefeitura está com a força'. Notese, inicialmente, que governo e prefeitura são concebidos como uma única coisa. A extensão desse poder estabelecido a partir do controle da prefeitura parece variar segundo a dependência maior ou menor da população em relação aos benefícios que podem ser concedidos pelo poder público local. Nas circunstâncias descritas pelo senador, a força da prefeitura emana da presença contínua na vida da 'população humilde' e, especialmente, dos auxílios concedidos em momentos socialmente significativos como nascimento e morte. Como há uma dependência dessa população em relação à prefeitura, vê-se, portanto, que as disputas em torno da mesma - desenvolvidas não entre candidatos individuais ou partidos, mas, efetivamente, entre grupos locais, como sugerem as investigações sobre o poder local no Brasil - ocorrem devido ao interesse em se dispor dos instrumentos que permitem intervir diretamente na vida destas pessoas ou evitar que os mesmos fiquem nas mãos dos inimigos. E se, como vimos acima, eleitores e comunidades tendem a valorizar o atendimento de suas demandas imediatas e este é um meio de manter pessoas numa condição de dependência pessoal ('devendo favores'), o controle do Executivo Municipal, conclui-se, é um meio de atender a essas demandas e de construir uma base de apoio político através do estabelecimento de vínculos de dependência pessoal".

473 Vide item 2.3.2.

474 O sentido verbal é descrito tanto no Cambridge International Dictionary of English (Editor Paul Procter. New York: Cambridge University Press, 1995, p. 834) quanto no Oxford Advanced Learner's Dictionary of Current English (Editor Jonathan Crowther. $5^{\mathrm{a}}$ ed. Oxford: Oxford University Press, 1995, p. 690). 
sindicatos e associações de classe mantêm escritórios (ou contratam escritórios especializados) devidamente registrados em Washington, que acompanham atentamente as atividades do Legislativo"; os referidos escritórios "preparam argumentos, organizam campanhas e fazem diversos tipos de movimentação para tentar impedir a aprovação de leis desfavoráveis aos grupos ou empresas que representam, ou acelerar a tramitação e obter a aprovação daquelas que interessam a tais grupos" ${ }^{\text {475 }}$.

No Brasil, embora não exista regulamento a respeito, o lobby é comum no Congresso Nacional, sendo praticado por intermédio de grupos de pressão ou por escritórios de consultoria. Não se pode afirmar, no entanto, que a prática do $l o b b y^{476}$, por si só, represente ilegalidade. Conforme ressalta Sérgio Habib ${ }^{477}$,

Quando esses grupos - ou essas pessoas - atuam dentro dos padrões da normalidade, isto é, quando propugnam em favor de causas justas ou por lídimos interesses, sem a utilização de métodos escusos, nada há que se argüir em desfavor dos mesmos. Mas, quando, deixando de lado os princípios éticos e morais venham a optar pelos caminhos sinuosos e esquivos da corrupção, seja patrocinando privilégios e vantagens, seja representando interesses menores e abomináveis, não há como deixar de impedir-lhes as ações e cercear-lhes os passos. Exatamente nessas horas é que a lei nem sempre se apresenta eficaz como deveria.

No âmbito do processo de aprovação das emendas ao orçamento e da liberação dos respectivos recursos, as atividades de lobby representam comportamentos caçadores de renda (rent-seeking), pois seus beneficiários procuram obter proveito econômico com a disponibilização das verbas, sem a preocupação direta com o interesse nacional.

A atuação desses grupos de pressão ocorre em duas frentes. Uma delas é a intermediação dos interesses de prefeitos junto a ministérios e demais órgãos federais localizados em Brasília, principalmente com a finalidade de promover a liberação de recursos já aprovados em emendas ao orçamento.

Outra atividade consiste na ação direta sobre os parlamentares, situação na qual o lobista $^{478}$ procura defender interesses de empresas ou de grupo de empresas, muitas vezes empreiteiras, com a finalidade de convencer deputados ou senadores à proposição de emendas ao orçamento para determinadas localidades. $\mathrm{O}$ retorno econômico às empresas ocorreria com a aprovação das emendas e posterior liberação das verbas, pois seriam beneficiadas com as obras públicas decorrentes dos projetos. No caso das empreiteiras, o

Dicionário de administração e finanças. São Paulo: Editora Best Seller, 2003, pp. 287-288.

476 Vide item 2.2 do presente estudo, referente ao rent-seeking.

477 Brasil: quinhentos anos de corrupção: enfoque sócio-histórico-jurídico-penal. Porto Alegre: Sérgio Antonio Fabris Editor, 1994, p. 88.

478 Pessoa que pratica o lobby. 
objetivo é que elas sejam contratadas pelos municípios ou estados favorecidos para a execução das obras. Relacionamentos desse tipo, porém, incentivam atos de corrupção, envolvendo inclusive autoridades e funcionários públicos dos entes subnacionais, responsáveis por facilitar a contratação das empresas mediante fraude no procedimento licitatório.

O lado pernicioso do vínculo entre lobistas e parlamentares ficou evidente em 1993, quando, por intermédio da Comissão Parlamentar de Inquérito (CPI), denominada "CPI dos Anões do Orçamento" ${ }^{\text {"49 }}$, foram descobertas fraudes na elaboração da lei orçamentária anual. Um dos esquemas investigados consistia no poder exercido por sete parlamentares (os “anões”) sobre a CMO. Como àquela época não existiam restrições fortes à apresentação de emendas, esse pequeno grupo apresentava várias delas com o objetivo de favorecer grupos de seu interesse, tais como suas bases eleitorais e empreiteiras ${ }^{480}$. O esquema contou com a participação de lobistas e funcionários públicos, os quais proporcionavam a liberação das verbas objeto das emendas.

Nessa CPI também se constatou um segundo esquema que favorecia diretamente os parlamentares envolvidos e tinha como objeto os recursos destinados às subvenções sociais. De acordo com Marcos Fernandes Gonçalves da Silva ${ }^{481}$, o arranjo se estruturava da seguinte forma:

Os parlamentares envolvidos procuravam criar e cadastrar instituições sociais no Conselho Nacional de Serviço Social. As entidades, uma vez cadastradas, poderiam receber verbas

479 Assim denominada em razão da baixa estatura dos integrantes do esquema.

480 De acordo com Marcos Fernandes Gonçalves da Silva (A economia política da corrupção no Brasil. São Paulo: SENAC São Paulo, 2001, p. 93), o esquema envolvia importante participação das empreiteiras: "O primeiro esquema de corrupção está ligado às empreiteiras, que atuavam na forma de rodízios para ganhar as licitações - etapa fundamental para a execução dos gastos. O cartel das empreiteiras promovia também a permuta de obras, sem qualquer controle de concorrência pública que avaliasse custos e outros itens importantes referentes à qualidade do serviço. $\mathrm{O}$ superfaturamento e a terceirização de atividades aparecem com freqüência, o que indica subempreitada de obras.

Ademais, as próprias empreiteiras propunham obras para prefeituras, já oferecendo os projetos acabados, com custos e especificações predeterminados. Cabia aos deputados e membros dos executivos locais pressionar os ministérios para a liberalização das verbas previstas nas dotações orçamentárias.

Outra forma de atuação das empreiteiras era propor obras para governantes locais, os quais acionavam seus representantes no Legislativo, que, por sua vez, procuravam incluir emendas na etapa de elaboração da proposta orçamentária no DOU ou na etapa posterior, quando o orçamento era discutido no Congresso e se elaborava a proposta dentro da casa - os deputados que 'representavam' os interesses das empreiteiras recebiam, estima-se, entre $5 \%$ e $20 \%$ do valor da obra.

Todas essas etapas aparentemente envolviam propinas, dadas a funcionários do esquema e aos políticos que ‘administravam' a CO [CMO]. Segundo consta, uma vez aprovadas as emendas de interesse das empreiteiras, os deputados recebiam parte da propina, o restante sendo pago com a liberação das verbas para as obras. O esquema era eficiente, pois forçava os políticos a fazerem pressão junto ao Executivo pelo descontingenciamento de verbas".

481 A economia política da corrupção no Brasil. São Paulo: SENAC São Paulo, 2001, p. 94. 
orçamentárias da União. Contudo, a maior parte delas era controlada pelos próprios parlamentares ou por familiares seus. Muitos parlamentares também alienavam todo seu patrimônio ou parte dele para essas instituições, de tal forma a alegarem ausência de fortuna pessoal. Fraudes como emissão de notas falsas e emprego de funcionários 'fantasmas' constituíram regra nessas entidades, já que o principal objetivo destas era desviar e privatizar recursos públicos. Também comum era a troca de emendas entre os parlamentares envolvidos, conforme o interesse de cada um. Ademais, dentro do extinto Ministério da Ação Social, os deputados faziam pressão para liberar as verbas contingenciadas e, na grande parte dos casos, obtinham sucesso. Esse esquema foi caracterizado pelo clientelismo político e, ao contrário do esquema das empreiteiras, englobava somente os parlamentares da $\mathrm{CO}$ [CMO Comissão Mista de Planos, Orçamentos Públicos e Fiscalização].

Outros exemplos da presença de corrupção podem ser depreendidos a partir da análise de duas operações da Polícia Federal, iniciadas a pedido do Ministério Público Federal: a Operação Sanguessuga e a Operação Navalha.

Iniciada em maio de 2006, a Operação Sanguessuga consistiu na investigação da ocorrência de fraudes em licitações na área da saúde. Segundo as apurações da Polícia Federal e denúncia do Ministério Público Federal em Mato Grosso, descobriu-se um ajuste no qual participavam assessores de parlamentares, deputados, senador, prefeitos, funcionários de uma empresa denominada Planam e uma assessora do Ministério da Saúde. O esquema era estruturado da seguinte forma: a quadrilha negociava com assessores de deputados a apresentação de emendas individuais ao orçamento federal. Vencida essa etapa, a liberação dos recursos aos municípios era facilitada mediante a intervenção de membros da quadrilha junto ao Ministério da Saúde. Várias empresas de fachada ${ }^{482}$ eram, então, criadas para participar de licitações para o fornecimento de ambulâncias a esses municípios. Os respectivos prefeitos, orientados pela empresa Planam Indústria, Comércio e Representação Ltda., direcionavam a licitação às mencionadas empresas de fachada, que apresentavam preços superfaturados (superiores ao valor de mercado em cerca de 120\%). Os valores recebidos pela empresa "vencedora" do certame eram divididos entre os integrantes da quadrilha ou utilizados para o pagamento de propina. Apurou-se que o referido esquema funcionava desde 2001 e movimentou cerca de R\$ 110 milhões $^{483}$.

A Operação Navalha consistiu numa ação da Polícia Federal em parceria com a Controladoria-Geral da União (CGU), deflagrada em maio de 2007, com a finalidade de

482 Empresas que, na realidade, não funcionam; são empresas de aparência, falsas.

483 A estrutura do esquema era complexa e funcionava em várias partes do país, com a participação de prefeitos. Bem por isso, existem denúncias do Ministério Público Federal em muitos estados, tais como Tocantins, Rondônia, Bahia, Alagoas, São Paulo, Espírito Santo, Goiás, Mato Grosso etc. Relatos sobre cada um desses casos podem ser encontrados no seguinte site do Ministério Público Federal: http://noticias.pgr.mpf.gov.br. 
investigar um esquema que envolvia pagamento de propinas a funcionários públicos e políticos de todos os níveis da federação, desvio de recursos destinados a obras públicas e fraudes em licitações. De acordo com as investigações da Polícia Federal e denúncia do Ministério Público Federal, o chefe do esquema seria o dono da Construtora Gautama, Zuleido Veras. A empresa possuía sede em São Paulo e filiais em muitos estados do país (Rio de Janeiro, Sergipe, Maranhão, Pernambuco, Alagoas, Amazonas, Bahia e Distrito Federal). $\mathrm{O}$ arranjo baseava-se no pagamento de propinas a funcionários públicos e lobistas para viabilizarem o desvio de recursos públicos para a quadrilha, mediante o direcionamento de editais e a disponibilização de verbas para obras superfaturadas, executadas irregularmente ou até mesmo inexistentes. Políticos e ex-políticos também atuavam no esquema, principalmente para facilitar a liberação de recursos e impedir a fiscalização das obras. Teriam sido objeto da fraude as verbas destinadas ao Programa de Aceleração do Crescimento (PAC), ao Programa Luz para Todos, ao Departamento Nacional de Infraestrutura de Transportes (Dnit), além de recursos de alguns ministérios (das Cidades, da Fazenda, de Minas e Energia, da Integração Nacional e do Planejamento). A ação penal contra os envolvidos encontra-se em trâmite na Corte Especial do Superior Tribunal de Justiça $^{484}$.

Como se pode depreender, a participação de empreiteiras é muito grande nesses esquemas de corrupção, denotando o interesse que possuem na alocação de recursos públicos para benefício próprio. A influência direta dessas empresas em momento anterior e posterior ao processo de aprovação da lei orçamentária anual é igualmente relevante. Sobre esse aspecto, Marcos Otávio Bezerra ressalta que as empreiteiras atuam em diversos níveis: a) na esfera municipal e estadual, tentam influenciar os governantes no estabelecimento de prioridades para as respectivas regiões; b) em relação aos estados, procuram ainda exercer influência nas propostas orçamentárias dos órgãos estaduais a serem enviadas aos ministérios; c) no âmbito ministerial, o encaminhamento de pleitos com o objetivo de que recursos sejam inseridos no planejamento orçamentário desses ministérios, bem como com a finalidade de liberação de verbas já aprovadas em emendas individuais ou de bancada; d) junto aos parlamentares, exercem pressão para que as proposições encaminhadas aos ministérios sejam mantidas e que, no âmbito da CMO, esses deputados e senadores defendam os recursos já contemplados na proposta do Executivo; na hipótese de nenhuma dessas situações ocorrer, os parlamentares são incentivados a propor emendas para viabilizar

484 Sob a relatoria da Ministra Eliana Calmon (processos: APn 536/BA e Inq 544/BA). 
as propostas das empreiteiras. Um instrumento de pressão exercido sobre deputados e senadores refere-se ao apoio político que as empreiteiras podem disponibilizar, inclusive por intermédio de contribuições de campanha ${ }^{485}$.

Deve-se ressaltar que a solução para as hipóteses acima analisadas não exige apenas uma regulamentação da prática do lobby (aí também incluída a atuação das empreiteiras no Congresso Nacional) ${ }^{486}$, com vistas a tornar mais transparente uma prática quase clandestina $^{487}$. O problema é mais profundo e exige uma maior descentralização da federação em todos os níveis (fiscal, de políticas etc.), com maior autonomia aos entes subnacionais, a fim de impedir que determinados mecanismos, como os recursos de emendas ao orçamento, sejam utilizados como instrumento para viabilizar práticas (clientelistas, patrimonialistas e corruptas) de grupos específicos, em claro prejuízo à federação e ao interesse nacional.

4.5.4 O poder em mãos do governo central: a troca de favores e a liberação de verbas objeto das emendas

Estudou-se no item 4.4.2 a possibilidade de o Presidente da República vetar total ou parcialmente a redação final do projeto de lei orçamentária; pode ele, dessa forma, também vetar as emendas ao orçamento apresentadas pelos parlamentares ou pelas bancadas estaduais.

Essa faculdade, no entanto, é utilizada pelo chefe do Poder Executivo de forma esporádica, uma vez que seu uso, nessa fase, apenas precipitaria o surgimento de desgastes políticos. Ora, por ser o orçamento considerado uma lei autorizativa e não impositiva, o Executivo, no mais das vezes, não executa todas as despesas previstas na peça orçamentária, mas somente o que lhe convém. Eventual gasto público contido em emenda parlamentar poderá, dessa forma, ser simplesmente ignorado pelo poder central na fase de execução do orçamento.

485 Em nome das "bases": política, favor e dependência pessoal. Rio de Janeiro: Relume Dumará/Núcleo de Antropologia da Política, 1999, pp. 231-254, passim.

486 Existe um projeto de lei (PL 1202/2007) em trâmite na Câmara dos Deputados que propõe a regulamentação da atividade de lobby, bem como a atuação de grupos de pressão ou de interesse e assemelhados no âmbito dos órgãos e entidades da Administração Pública Federal.

487 A expressão "clandestina" é utilizada no sentido de "oculta", e não na acepção de ilegítima ou ilegal, embora algumas vezes, como visto, o lobby também possa assim se caracterizar. 
Surge, com isso, um instrumento de barganha utilizado pelo governo central para viabilizar seus projetos, muito similar à prática do logrolling.

O termo logrolling (assistência mútua) significa a troca de favores entre parlamentares com o objetivo de obter aprovação em projetos de lei de seu interesse ${ }^{488}$. No âmbito do Congresso Nacional brasileiro e de outros parlamentos no mundo essa prática não é rara. Afirma Hugo Borsani que, em razão de os legisladores possuírem diferentes níveis de interesse nas propostas de lei apresentadas no Congresso, o logrolling é facilitado, permitindo "negociações por leis e emendas, freqüentes na maioria dos sistemas democráticos, cujo objetivo é que todos os integrantes da negociação fiquem satisfeitos com o resultado" 489 .

A prática do logrolling está intimamente ligada à presença de minorias no Poder Legislativo - principalmente no Brasil, em que a super-representação de estados menores inibe o poder da maioria democrática (demos constraining) ${ }^{490}$-, pois "abre a possibilidade para que as minorias, se representadas no Parlamento, encontrem, mediante negociações, espaço para aprovação de projetos" ${ }^{491}$.

O seu exercício pode ou não representar prejuízo à federação, dependendo da forma como é realizado. Se o resultado social final for positivo, é um indicativo de que o logrolling alcançou o equilíbrio na troca de votos. De acordo com Hugo Borsani, isso "acontece quando o custo de votar determinada medida iguala o benefício esperado pela aprovação da opção mais intensamente preferida. Assim, o bem-estar é otimizado pela combinação da regra da maioria com logrolling, ${ }^{492}$.

O problema é quando a troca de favores é utilizada como mecanismo para estruturar uma coalizão com o propósito de viabilizar a administração por parte do poder central, situação que ocorre no Brasil ${ }^{493}$.

488 Ressalta Hugo Borsani (Relações entre política e economia: Teoria da Escolha Pública. In: ARVATE, Paulo; BIDERMAN, Ciro (org.). Economia do setor público no Brasil. Rio de Janeiro: Elsevier, 2004, p. 111) que a expressão indica "o intercâmbio de votos (vote trade) entre os legisladores para aprovação de diferentes leis".

489 Relações entre política e economia: Teoria da Escolha Pública. In: ARVATE, Paulo; BIDERMAN, Ciro (org.). Economia do setor público no Brasil. Rio de Janeiro: Elsevier, 2004, p. 111.

490 Vide item 3.7.1 do presente estudo.

491 Hugo Borsani. Relações entre política e economia: Teoria da Escolha Pública. In: ARVATE, Paulo; BIDERMAN, Ciro (org.). Economia do setor público no Brasil. Rio de Janeiro: Elsevier, 2004, p. 113).

492 Relações entre política e economia: Teoria da Escolha Pública. In: ARVATE, Paulo; BIDERMAN, Ciro (org.). Economia do setor público no Brasil. Rio de Janeiro: Elsevier, 2004, p. 113.

493 Sobre essa questão, Hugo Borsani (Relações entre política e economia: Teoria da Escolha Pública. In: ARVATE, Paulo; BIDERMAN, Ciro (org.). Economia do setor público no Brasil. Rio de Janeiro: 
Aliás, a utilização do logrolling como instrumento para atrair votos favoráveis a projetos de interesse do governo central é objeto de estudo da doutrina. Márcio André de Carvalho, ao analisar a atuação de deputados nos anos de 1995 a 1998 - época em que o então Presidente da República Fernando Henrique Cardoso apresentou diversas emendas constitucionais de índole econômica e social -, concluiu que a troca de votos provocou um efeito pérfido à sociedade, gerando custos não previstos pelo governo federal. Institucionalizou-se um sistema prejudicial ao interesse público: em troca de seus votos, necessários à aprovação das propostas governamentais, os deputados passaram a sempre exigir algum tipo de contrapartida ${ }^{494}$.

No Brasil, essa troca de favores com o objetivo de proporcionar a coalizão do governo federal também é exercida no âmbito do orçamento, envolvendo o Poder Executivo e parlamentares. Ocorre que, nesse caso, a situação é ainda mais prejudicial e de efeitos imediatos, pois são utilizados como moeda de troca recursos orçamentários, previstos em emendas parlamentares, para fazer prevalecer os projetos do governo central.

Ademais, ao se considerar que determinadas emendas deveriam ser vetadas pelo Presidente da República já na fase anterior à aprovação da lei orçamentária, sua utilização como barganha política somente confirma o alto custo social a ser suportado pela

Elsevier, 2004, p. 112) apresenta dados concretos a respeito da ocorrência do fenômeno no Brasil: "Um exemplo de logrolling no Brasil foi o recente processo de aprovação das Reformas Previdenciária e Tributária (ano 2003). A coalizão majoritária no governo negociou a aprovação do subteto da remuneração dos desembargadores e a contribuição previdenciária dos inativos no âmbito da Reforma Previdenciária (...), em troca do aumento da participação dos estados da federação nas receitas decorrentes da CIDE (Contribuição de Intervenção no Domínio Econômico) e da CPMF - Contribuição Provisória sobre Movimentação Financeira (...) - no bojo da Reforma tributária (...). A moeda de troca foi o voto dos parlamentares fiéis aos governadores. O processo de logrolling foi coordenado e negociado pelo presidente da República, pelos governadores dos estados e pelos líderes partidários no Legislativo".

494 How logrolling can explain the failure of the government coalition in Brazil. In: Revista de Administração Pública, Rio de Janeiro, v. 40, n. 5, set-out de 2006, pp. 865-882. Disponível em http://www.scielo.br/scielo.php?script=sci_arttext\&pid=S0034-76122006000500006\&lng=pt\&nrm=iso, acessado em 04.01.2010. O autor afirma que, no período indicado, existiam três grupos na Câmara dos Deputados: a) um grupo estável de coalizão governamental, mas com número insuficiente para aprovar as emendas constitucionais; b) um grupo formado pela oposição, que poderia votar contra os interesses do governo; c) um grupo que oscilava entre a oposição e a base governamental, dependendo dos favores que poderiam ou não obter do poder central. No original: "The movement of representatives in and out of the governmental coalition indicate that logrolling was the strategy used by the government in order to have the necessary number votes to approve the constitutional amendments proposed by the president. Therefore, during the period 1995-98, members of the House of Representatives could have been part of three groups: a stable governmental coalition - not large enough to approve the constitutional amendments; the opposition that would always vote against the government; or a group that would oscillate between government and opposition, depending on the benefits that it could trade - logroll with the government" (Op. cit., p. 868). 
sociedade. Vale dizer, mais uma vez os recursos são desviados de seu destino, deixando de atender o interesse nacional para servir a pleitos regionalizados ou de comunidades locais.

A situação acima mencionada demonstra, aliás, o grande poder exercido pelo Executivo federal na questão orçamentária.

Importante considerar que o conjunto das emendas individuais e de bancada, em relação ao valor total do orçamento, representa apenas uma ínfima parcela, denotando que, na verdade, os parlamentares não exercem domínio sobre grande parte das rubricas orçamentárias. Conforme ressaltam Carlos Pereira e Bernardo Mueller, "as regras determinam que o Congresso só pode influir nos recursos da rubrica investimentos, que tem respondido por apenas $1 \%$ a $2 \%$ de todas as despesas orçamentárias"495.

Percebe-se que é o Executivo, na realidade, que exerce a maior influência sobre o orçamento, controlando a maioria dos procedimentos referentes à proposição e execução da lei orçamentária.

Antes do encaminhamento do projeto ao Congresso Nacional, o Poder Executivo é responsável por coordenar e elaborar a proposta de orçamento anual, momento em que os ministérios apresentarão suas programações de gastos. De posse dessas informações e antes do envio da proposta ao Congresso, o Executivo pode barganhar com parlamentares a inclusão de novos projetos ou o aumento da previsão de receitas para demandas específicas.

O domínio desempenhado pelo Executivo, contudo, vai além: a) na própria CMO, realiza controle sobre a indicação de nomes para os principais cargos, interferindo, assim, nas emendas ao orçamento federal ${ }^{496}$; b) após a aprovação pelo Congresso Nacional, as

495 Comportamento estratégico em presidencialismo de coalizão: as relações entre Executivo e Legislativo na elaboração do orçamento brasileiro. In: Dados - Revista de Ciências Sociais, Rio de Janeiro, v. 45, $\mathrm{n}^{\circ}$ 2, 2002, p. 281. Também disponível em http://www.scielo.br/scielo.php?script=sci_arttext\&pid=S001152582002000200004\&lng=en\&nrm=iso, acessado em 05.01.2010. Como exemplo dos dados apresentados pelo autor, percebem-se os valores contidos na proposta orçamentária da União para 2010 (aprovada pelo Congresso Nacional e pendente de sanção do Presidente da República): enquanto o orçamento total foi de $\mathrm{R} \$ 1,86$ trilhão, o valor orçado para investimentos públicos chegou à quantia de $\mathrm{R} \$ 58,1$ bilhões (antes das emendas parlamentares, essa quantia representava $\mathrm{R} \$ 44,5$ bilhões). Ressaltase que mesmo após os descontos de recursos para rolagem da dívida pública (R\$ 596, 2 bilhões) o valor total do orçamento ainda se mostra expressivo ( $\mathrm{R} \$ 1,26$ trilhão).

496 Sobre essa questão, Carlos Pereira e Bernardo Mueller (Comportamento estratégico em presidencialismo de coalizão: as relações entre Executivo e Legislativo na elaboração do orçamento brasileiro. In: Dados - Revista de Ciências Sociais, Rio de Janeiro, v. 45, $\mathrm{n}^{\circ}$ 2, 2002, p. 269. Também disponível em http://www.scielo.br/scielo.php?script=sci_arttext\&pid=S0011-52582002000200004\&lng=en\&nrm=iso, acessado em 05.01.2010) ressaltam: "Visto que as nomeações para esses cargos são feitas pelas lideranças partidárias, respeitando o tamanho relativo de cada legenda no Congresso, são os líderes dos 
emendas podem ser vetadas pelo Presidente da República; c) no momento da execução orçamentária, escolhe apenas determinadas emendas que lhe possam trazer retorno político; a liberação de recursos pode ser utilizada, assim, como incentivo à aprovação das propostas do governo, enquanto que o bloqueio das verbas funciona como punição pela não cooperação dos parlamentares.

Apesar da pouca influência exercida por deputados e senadores em relação à totalidade do orçamento, eles dependem dos recursos objeto das emendas; como já afirmado, é a liberação das verbas que garante o retorno político aos parlamentares e a fidelidade de suas bases eleitorais. O círculo vicioso clientelista é alimentado pelo próprio Poder Executivo, uma vez que utiliza a liberação de recursos das emendas como forma de ampliar seu domínio sobre os votos dos parlamentares em projetos estratégicos do governo federal. O governo de coalizão é viabilizado, dessa forma, em prejuízo da sociedade, que se vê privada da alocação adequada e eficaz de recursos públicos.

\subsection{As transferências intergovernamentais}

\subsubsection{A utilização das transferências intergovernamentais como forma de proporcionar a equalização fiscal}

Já foi afirmado no presente estudo que a federação brasileira utiliza regras formais e informais para viabilizar a equalização fiscal entre os entes federados, inclusive para diminuir a desigualdade existente entre os estados e regiões do país. Dentre as regras informais estão as emendas ao orçamento, já estudadas nos itens antecedentes. Quanto às formais, as principais dizem respeito às transferências intergovernamentais.

As mencionadas transferências dizem respeito à remoção de recursos entre os entes federados e constituem um mecanismo relevante numa federação cooperativa.

A existência do mecanismo das transferências é necessária, dentre outros motivos, em razão da dificuldade que os entes subnacionais encontram ao arrecadar de forma eficaz ou suficiente seus próprios tributos para fazer frente às respectivas provisões de bens e serviços públicos (desequilíbrio vertical). Como os tributos instituídos pelo poder central é que representam maior volume de recursos arrecadados, haveria um desequilíbrio fiscal se

partidos que compõem a base de sustentação do governo que, na realidade, detêm o controle sobre o processo de elaboração do orçamento, porque eles têm uma confortável maioria no Legislativo". 
não houvesse uma repartição do produto da arrecadação entre os demais níveis governamentais. O mesmo raciocínio aplica-se na relação entre estados e municípios ${ }^{497}$.

As desigualdades regionais também podem ser minimizadas mediante a utilização do mesmo procedimento de transferências, deslocando-se recursos do governo central e de estados mais desenvolvidos para regiões ou municípios com nível de desenvolvimento menor ou que não apresentem capacidade tributária suficiente (desequilíbrio horizontal) ${ }^{498}$.

As hipóteses em que se procura corrigir desequilíbrios vertical e horizontal favorecem a implantação de uma estabilização entre os entes federados e a harmonização da federação.

Outra utilidade das transferências intergovernamentais é a sua utilização para corrigir externalidades, como forma de compensar localidades ou regiões negativamente afetadas ${ }^{499}$.

É ainda possível o uso das transferências para implementar a função físcal estabilizadora: o governo central, em situações de declínio da atividade econômica, pode majorar os recursos destinados aos entes subnacionais; já em situações de aumento da atividade econômica, os deslocamentos desses mesmos recursos pode ser diminuído.

\subsubsection{Classificação das transferências intergovernamentais}

Para a finalidade do presente estudo, as transferências intergovernamentais podem ser classificadas da seguinte forma:

a) quanto ao nível governamental da transferência, esta pode ser horizontal, quando se referir ao direcionamento de recursos entre integrantes da mesma esfera federativa; ou vertical , quando envolver níveis de governo diversos;

497 Vide item 1.6.2 do presente trabalho. No que se refere ao desequilíbrio vertical, Sérgio Prado (Equalização e federalismo fiscal: uma análise comparada: Alemanha, Índia, Canadá, Austrália. Rio de Janeiro: Konrad-Adenauer-Stiftung, 2006, p. 19) adota a expressão "brecha vertical": "Numa formulação sintética, as questões centrais do federalismo fiscal se referem à formatação de mecanismos e instituições para lidar com o que é referido, no jargão técnico, como brecha vertical, ou 'vertical gap': as características estruturais das federações modernas, no que se refere à atribuição de receitas $e$ encargos (tomados num sentido amplo) entre níveis de governo, resultam na relativa concentração de recursos nos governos superiores e de encargos nos GSN [governos subnacionais], tornando necessárias transferências verticais em geral de grande porte, pelas quais se define a distribuição final de capacidade de gasto entre níveis de governo" (destaques contidos no original).

499 Sobre essa questão, vide item 1.6.3 deste estudo. 
b) quanto ao nível de comprometimento entre os entes, as transferências podem ser obrigatórias, quando a lei ou a Constituição Federal é que determinam o direcionamento dos recursos; ou voluntárias, quando o compromisso entre as esferas governamentais para a remoção de recursos é estabelecido por meio de acordo, convênio ou cooperação financeira. No Brasil, são exemplos de transferências obrigatórias as hipóteses disciplinadas nos artigos 157 a 159 da Constituição Federal. Não obstante a transferência voluntária ser fruto de ajuste entre os entes federados envolvidos (não necessitando, assim, de lei), no caso da União, os recursos destinados a essa espécie de transferência deverão ter previsão na lei orçamentária anual;

c) quanto à forma de repartição, a transferência pode ser direta ou indireta. Diz-se que a repartição é direta quando a quantidade de recursos a serem deslocados é calculada diretamente do produto da arrecadação do nível governamental superior ${ }^{500}$. Já a repartição indireta é aquela transferência realizada por intermédio de fundos ou programas ${ }^{501}$;

500 No ordenamento jurídico brasileiro, a repartição direta é prevista nos artigos 157 e 158 da Constituição Federal: “Art. 157. Pertencem aos Estados e ao Distrito Federal: I - o produto da arrecadação do imposto da União sobre renda e proventos de qualquer natureza, incidente na fonte, sobre rendimentos pagos, a qualquer título, por eles, suas autarquias e pelas fundações que instituírem e mantiverem; II - vinte por cento do produto da arrecadação do imposto que a União instituir no exercício da competência que lhe é atribuída pelo art. 154, I. Art. 158. Pertencem aos Municípios: I - o produto da arrecadação do imposto da União sobre renda e proventos de qualquer natureza, incidente na fonte, sobre rendimentos pagos, a qualquer título, por eles, suas autarquias e pelas fundações que instituírem e mantiverem; II - cinqüenta por cento do produto da arrecadação do imposto da União sobre a propriedade territorial rural, relativamente aos imóveis neles situados, cabendo a totalidade na hipótese da opção a que se refere o art. $153, \S 4^{\circ}$, III; III - cinquienta por cento do produto da arrecadação do imposto do Estado sobre a propriedade de veículos automotores licenciados em seus territórios; IV - vinte e cinco por cento do produto da arrecadação do imposto do Estado sobre operações relativas à circulação de mercadorias e sobre prestações de serviços de transporte interestadual e intermunicipal e de comunicação. Parágrafo único. As parcelas de receita pertencentes aos Municípios, mencionadas no inciso IV, serão creditadas conforme os seguintes critérios: I - três quartos, no mínimo, na proporção do valor adicionado nas operações relativas à circulação de mercadorias e nas prestações de serviços, realizadas em seus territórios; II - até um quarto, de acordo com o que dispuser lei estadual ou, no caso dos Territórios, lei federal".

501 No Brasil, a repartição indireta é disciplinada no artigo 159, da Constituição Federal: “Art. 159. A União entregará: I - do produto da arrecadação dos impostos sobre renda e proventos de qualquer natureza e sobre produtos industrializados quarenta e oito por cento na seguinte forma: a) vinte e um inteiros e cinco décimos por cento ao Fundo de Participação dos Estados e do Distrito Federal; b) vinte e dois inteiros e cinco décimos por cento ao Fundo de Participação dos Municípios; c) três por cento, para aplicação em programas de financiamento ao setor produtivo das Regiões Norte, Nordeste e CentroOeste, através de suas instituições financeiras de caráter regional, de acordo com os planos regionais de desenvolvimento, ficando assegurada ao semi-árido do Nordeste a metade dos recursos destinados à Região, na forma que a lei estabelecer; d) um por cento ao Fundo de Participação dos Municípios, que será entregue no primeiro decêndio do mês de dezembro de cada ano; II - do produto da arrecadação do imposto sobre produtos industrializados, dez por cento aos Estados e ao Distrito Federal, proporcionalmente ao valor das respectivas exportações de produtos industrializados. III - do produto da arrecadação da contribuição de intervenção no domínio econômico prevista no art. 177, § 4 $29 \%$ (vinte e nove por cento) para os Estados e o Distrito Federal, distribuídos na forma da lei, observada a destinação a que se refere o inciso II, $c$, do referido parágrafo. $\S 1^{\circ}$ - Para efeito de cálculo da entrega a 
d) quanto à aplicação dos recursos, as transferências podem ser condicionais ou incondicionais. Quando o recurso deslocado deva ser aplicado a políticas públicas ou destinos específicos, diz-se que se trata de transferência condicional (é o caso, por exemplo, dos recursos direcionados ao fundo de financiamento das Regiões Norte, Nordeste e CentroOeste, disciplinado no artigo 159, inciso I, alínea “c”, da Constituição Federal). Tais transferências podem ser realizadas, ainda, com ou sem contrapartida. Marcos Mendes explica que "uma transferência condicional é classificada como com contrapartida se o montante transferido pelo doador é proporcional ao montante que o receptor aplica no gasto incentivado"; o mesmo autor exemplifica: "o governo central pode estabelecer que transferirá, para os estados, $\mathrm{R}$ \$ 0,15 para cada $\mathrm{R} \$ 1,00$ que aquele estado aplicar em política de preservação do meio ambiente" ${ }^{, 502}$. As transferências incondicionais são aquelas em que a utilização dos recursos pelo ente que os recebe ocorre de forma livre, sem restrições (recursos provenientes dos fundos de participação dos estados, distrito federal e municípios, por exemplo).

Com a finalidade de estudar as implicações existentes entre as transferências intergovernamentais e o desvio de recursos públicos, o presente trabalho se deterá à análise de duas espécies delas, quais sejam, as transferências obrigatórias indiretas - mais especificamente as provenientes dos fundos de participação dos estados e municípios - e as transferências voluntárias.

\subsubsection{Os fundos de participação: conceito, características e espécies}

Sob a ótica do Direito Financeiro, o fundo representa um dos mecanismos de gestão financeira do Estado. Não por acaso, o termo é conceituado por José Mauricio Conti “como sendo um conjunto de recursos utilizados como instrumento de distribuição de riqueza, cujas

ser efetuada de acordo com o previsto no inciso I, excluir-se-á a parcela da arrecadação do imposto de renda e proventos de qualquer natureza pertencente aos Estados, ao Distrito Federal e aos Municípios, nos termos do disposto nos arts. 157, I, e 158, I. $\S 2^{\circ}$ - A nenhuma unidade federada poderá ser destinada parcela superior a vinte por cento do montante a que se refere o inciso II, devendo o eventual excedente ser distribuído entre os demais participantes, mantido, em relação a esses, o critério de partilha nele estabelecido. $\S 3^{\circ}$ - Os Estados entregarão aos respectivos Municípios vinte e cinco por cento dos recursos que receberem nos termos do inciso II, observados os critérios estabelecidos no art. 158, parágrafo único, I e II. $\S 4^{\circ}$ Do montante de recursos de que trata o inciso III que cabe a cada Estado, vinte e cinco por cento serão destinados aos seus Municípios, na forma da lei a que se refere o mencionado inciso".

502 Federalismo fiscal. In: ARVATE, Paulo; BIDERMAN, Ciro (org.). Economia do setor público no Brasil. Rio de Janeiro: Elsevier, 2004, p. 435. 
fontes de receita lhe são destinadas para uma finalidade determinada ou para serem redistribuídas segundo critérios pré-estabelecidos"

De acordo com Regis Fernandes de Oliveira, os fundos podem ser de dois tipos: os de destinação e os de participação ${ }^{504}$.

Os fundos de destinação são aqueles estruturados para aplicação em finalidade específica. Representam transferências obrigatórias, pois determinadas mediante previsão legal ou constitucional. É exemplo dessa espécie de fundo o estabelecido pelo artigo 159, inciso I, alínea "c", da Constituição Federal ${ }^{505}$, que deu ensejo à instituição dos Fundos Constitucionais de Financiamento do Norte (FNO), Nordeste (FNE) e Centro-Oeste (FCO), cujos recursos são utilizados para o financiamento de programas no setor produtivo ${ }^{506}$.

Na verdade, a grande maioria dos fundos é de destinação: alguns criados pela Constituição Federal, como os citados acima; outros, instituídos mediante emenda constitucional, como é exemplo o Fundo de Manutenção e Desenvolvimento da Educação Básica e de Valorização dos Profissionais da Educação (FUNDEB) ${ }^{507}$; outros, ainda, criados por meio de leis específicas ${ }^{508}$.

503 Federalismo fiscal e fundos de participação. São Paulo: Editora Juarez de Oliveira, 2001, p. 76.

504 Curso de direito financeiro. São Paulo: Editora Revista dos Tribunais, 2006, p. 274.

505 Constituição Federal: “Art. 159. A União entregará: (...) I - do produto da arrecadação dos impostos sobre renda e proventos de qualquer natureza e sobre produtos industrializados quarenta e oito por cento na seguinte forma: (...) c) três por cento, para aplicação em programas de financiamento ao setor produtivo das Regiões Norte, Nordeste e Centro-Oeste, através de suas instituições financeiras de caráter regional, de acordo com os planos regionais de desenvolvimento, ficando assegurada ao semi-árido do Nordeste a metade dos recursos destinados à Região, na forma que a lei estabelecer; (...)".

506 A Lei $^{\circ} 7.827$, de 27 de setembro de 1989, regulamentou o dispositivo constitucional que criou esses fundos (art. 159, inciso I, alínea “c"). No artigo $2^{\circ}$ da mencionada lei consta expressamente a finalidade para a qual os recursos dos fundos serão aplicados: "Art. $2^{\circ}$ Os Fundos Constitucionais de Financiamento do Norte, Nordeste e Centro-Oeste têm por objetivo contribuir para o desenvolvimento econômico e social das regiões Norte, Nordeste e Centro-Oeste, através das instituições financeiras federais de caráter regional, mediante a execução de programas de financiamento aos setores produtivos, em consonância com os respectivos planos regionais de desenvolvimento. $\S 1^{\circ} \mathrm{Na}$ aplicação de seus recursos, os Fundos Constitucionais de Financiamento do Norte, Nordeste e Centro-Oeste ficarão a salvo das restrições de controle monetário de natureza conjuntural e deverão destinar crédito diferenciado dos usualmente adotados pelas instituições financeiras, em função das reais necessidades das regiões beneficiárias. $\S 2^{\circ}$ No caso da região Nordeste, o Fundo Constitucional de Financiamento do Nordeste inclui a finalidade específica de financiar, em condições compatíveis com as peculiaridades da área, atividades econômicas do semi-árido, às quais destinará metade dos recursos ingressados nos termos do art. 159, inciso I, alínea c, da Constituição Federal".

507 O FUNDEB foi instituído pela Emenda Constitucional n ${ }^{\circ} 53$, de 2006, que alterou o artigo 60 do Ato das Disposições Constitucionais Transitórias (ADCT), que passou a assim prever: “Art. 60. Até o $14^{\circ}$ (décimo quarto) ano a partir da promulgação desta Emenda Constitucional, os Estados, o Distrito Federal e os Municípios destinarão parte dos recursos a que se refere o caput do art. 212 da Constituição Federal à manutenção e desenvolvimento da educação básica e à remuneração condigna dos trabalhadores da educação, respeitadas as seguintes disposições: I - a distribuição dos recursos e de responsabilidades entre o Distrito Federal, os Estados e seus Municípios é assegurada mediante a criação, no âmbito de cada Estado e do Distrito Federal, de um Fundo de Manutenção e Desenvolvimento da Educação Básica 
$\mathrm{Na}$ criação desses fundos, o artigo $165, \S 9^{\circ}$, inciso II, determina que caberá à lei complementar estabelecer "condições para a instituição e funcionamento de fundos". A Lei 4.320/64, diante da inexistência de lei complementar a respeito, foi recepcionada como tal pela Constituição de $1988^{509}$ e disciplina, em seus artigos 71 a 74 , a criação e operacionalização desses fundos ${ }^{510}$.

Os fundos de participação, por outro lado, representam repartição de receita tributária e possuem previsão constitucional. No Brasil, é o caso do Fundo de Participação dos Estados e do Distrito Federal (FPE) e do Fundo de Participação dos Municípios $(\mathrm{FPM})^{511}$. São transferências intergovernamentais obrigatórias e incondicionais, não exigindo destinação específica, motivo pelo qual seus recursos podem ser usados livremente pelos entes subnacionais (estados e municípios).

Dentre todos os demais fundos, tanto o FPE quanto o FPM são os mais relevantes, inclusive em matéria de volume. A título de exemplo, para o orçamento de 2010 (valor total

e de Valorização dos Profissionais da Educação - FUNDEB, de natureza contábil; II - os Fundos referidos no inciso I do caput deste artigo serão constituídos por $20 \%$ (vinte por cento) dos recursos a que se referem os incisos I, II e III do art. 155; o inciso II do caput do art. 157; os incisos II, III e IV do caput do art. 158; e as alíneas a e b do inciso I e o inciso II do caput do art. 159, todos da Constituição Federal, e distribuídos entre cada Estado e seus Municípios, proporcionalmente ao número de alunos das diversas etapas e modalidades da educação básica presencial, matriculados nas respectivas redes, nos respectivos âmbitos de atuação prioritária estabelecidos nos $\S \S 2^{\circ}$ e $3^{\circ}$ do art. 211 da Constituição Federal; (...)”. O FUNDEB é atualmente regulamentado pela Lei n 11.494, de 20 de junho de 2007.

508 Sobre os fundos atualmente existentes, ver Regis Fernandes de Oliveira (Curso de direito financeiro. São Paulo: Editora Revista dos Tribunais, 2006, pp. 277-278), que apresenta uma relação de todos eles.

509 Nesse sentido é, inclusive, o entendimento do Supremo Tribunal Federal na Medida Cautelar em Ação Direta de Inconstitucionalidade $\mathrm{n}^{\circ}$ 1726/DF (Relator Ministro Maurício Corrêa, Tribunal Pleno, j. 16.09.1998), cujo excerto da ementa consta: “(...) 1. A exigência de prévia lei complementar estabelecendo condições gerais para a instituição de fundos, como exige o art. 165 , $\S 9^{\circ}$, II, da Constituição, está suprida pela Lei $n^{\circ} 4.320$, de 17.03.64, recepcionada pela Constituição com status de lei complementar; embora a Constituição não se refira aos fundos especiais, estão eles disciplinados nos arts. 71 a 74 desta Lei, que se aplica à espécie (...)".

510 Assim preveem os mencionados dispositivos da Lei 4.320/64: "Art. 71. Constitui fundo especial o produto de receitas especificadas que por lei se vinculam à realização de determinados objetivos ou serviços, facultada a adoção de normas peculiares de aplicação. Art. 72. A aplicação das receitas orçamentárias vinculadas a turnos especiais far-se-á através de dotação consignada na Lei de Orçamento ou em créditos adicionais. Art. 73. Salvo determinação em contrário da lei que o instituiu, o saldo positivo do fundo especial apurado em balanço será transferido para o exercício seguinte, a crédito do mesmo fundo. Art. 74. A lei que instituir fundo especial poderá determinar normas peculiares de contrôle, prestação e tomada de contas, sem de qualquer modo, elidir a competência específica do Tribunal de Contas ou órgão equivalente".

511 José Afonso da Silva (Comentário contextual à Constituição. São Paulo: Malheiros, 2005, pp. 680-681) inclui na categoria de "fundos de participação" os Fundos Constitucionais de Financiamento do Norte (FNO), Nordeste (FNE) e Centro-Oeste (FCO). Neste trabalho, contudo, opta-se por defini-los na categoria de "fundos de destinação" por possuírem destinações específicas, ao contrário dos fundos de participação dos estados e municípios, que são transferências intergovernamentais incondicionais. 
de $\mathrm{R}$ \$ 1,86 trilhão), estima-se que $\mathrm{R}$ \$ 156,3 bilhões serão destinados para esses fundos de participação $^{512}$.

O FPE e o FPM foram criados com a função precípua de diminuir as diferenças regionais entre os entes subnacionais (equilíbrio horizontal), bem como proporcionar a equalização necessária de recursos para que estados e municípios possam fazer frente aos seus encargos (equilíbrio vertical). Nesse sentido, Carlos Eduardo Gasparini e Fernando Andrés Blanco Cossio ${ }^{513}$, ao explicarem a utilização das transferências intergovernamentais no Brasil, trazem os fundamentos para a existência dos mencionados fundos de participação:

Em primeiro lugar, usam-se transferências para corrigir o chamado desequilíbrio vertical. Em sistemas federativos, um grande volume de gastos é executado de forma mais eficiente pelas instâncias mais descentralizadas (estados e municípios) enquanto a arrecadação da maioria dos tributos tende a ser mais eficiente se realizada pela União. O resultado é que estados e municípios arrecadam menos impostos do que o volume necessário para financiar todos os gastos que são de sua atribuição. [...]

Ou seja, os estados e municípios precisarão receber recursos adicionais, através de transferências, para poder financiar tais atividades, pois não arrecadam tributos em valor suficiente.

Além do desequilíbrio vertical há, também, o desequilíbrio horizontal, que resulta das desigualdades regionais existentes em uma federação. No Brasil, temos a clássica divisão entre o Sul-Sudeste, industrializado e de renda per capita mais alta, e o Norte-Nordeste em posição menos privilegiada. Assim, criaram-se mecanismos que transferem receitas arrecadadas no Sul-Sudeste para o Norte-Nordeste, de forma a permitir que a região desprivilegiada ofereça serviços públicos de qualidade equivalente aos da região mais privilegiada.

A preocupação com a equalização fiscal acima mencionada tanto é verdadeira que boa parte dos valores do FPE é destinada a estados pertencentes ao Norte, Nordeste e CentroOeste, enquanto os recursos do FPM direcionam-se, na grande maioria das vezes, a municípios localizados no interior dos estados.

4.6.4 Os critérios de apuração e repartição do Fundo de Participação dos Estados e do Distrito Federal (FPE) e do Fundo de Participação dos Municípios (FPM)

O critério de cálculo do Fundo de Participação dos Estados e do Distrito Federal, segundo a previsão contida no artigo 159, inciso I, alínea “a”, da Constituição Federal, é o

512 Jornal do Senado, ano XV, n 3.163, Brasília, 23/12/2009, p. 2.

513 Transferências intergovernamentais. In: MENDES, Marcos (org.). Gasto público eficiente: 91 propostas para o desenvolvimento do Brasil. São Paulo: Instituto Braudel/Topbooks, 2006, pp. 176-177. 
índice de $21,5 \%$ sobre o produto da arrecadação de dois impostos: o imposto sobre a renda e proventos de qualquer natureza e o imposto sobre produtos industrializados.

A base de cálculo para aplicação do referido índice deve considerar, no entanto, o valor líquido da arrecadação, ou seja, livre de incentivos fiscais, restituições, retificações e, ainda, deduzido da parcela da arrecadação do imposto de renda e proventos de qualquer natureza, incidente na fonte, sobre rendimentos pagos pelo próprio estado, suas autarquias e fundações que instituem e mantêm (artigo 159, § $1^{\circ}$, combinado com o artigo 157, inciso I, ambos da Constituição Federal).

Calculados os valores dirigidos ao fundo, passa-se, então, à repartição dos recursos entre os estados. $\mathrm{O}$ artigo $2^{\circ}$ da Lei Complementar $n^{\circ}$ 62, de 28 de dezembro de 1989, que estabelece normas sobre esse cálculo, determina que $85 \%$ dos recursos do FPE sejam destinados às unidades da federação das regiões Norte, Nordeste e Centro-Oeste; os $15 \%$ restantes, aos estados pertencentes às regiões Sul e Sudeste.

Após tal divisão, há uma nova partilha com base em três critérios $^{514}$ : a) 5\%, proporcionalmente à superfície de cada estado (ou Distrito Federal) participante, segundo apuração do Instituto Brasileiro de Geografia e Estatística (IBGE); b) 95\%, proporcionalmente ao coeficiente individual de participação, resultado da razão direta da população (estimada pelo IBGE) e inversa da renda per capita de cada estado (estimada pela Fundação Getúlio Vargas).

O cálculo para apuração do Fundo de Participação dos Municípios é similar ao do FPE. A base de cálculo é a mesma, ou seja, o produto da arrecadação do imposto sobre a renda e proventos de qualquer natureza e o imposto sobre produtos industrializados; a alíquota, porém, é diversa: $22,5 \%$ desse produto (artigo 159, inciso I, alínea "b", da Constituição Federal).

Da mesma forma que no FPE, considera-se como base de cálculo o valor líquido da arrecadação, ou seja, livre de incentivos fiscais, restituições, retificações e, também, deduzido da parcela da arrecadação do imposto de renda e proventos de qualquer natureza, incidente na fonte, sobre rendimentos pagos pelo próprio município, suas autarquias e

514 Esses critérios estão expressamente previstos nos artigos 88 a 89 do Código Tributário Nacional. José Maurício Conti (Federalismo fiscal e fundos de participação. São Paulo: Editora Juarez de Oliveira, 2001, pp. 87-90), de forma detalhada e minuciosa, explica o procedimento de aplicação dos mencionados critérios. 
fundações que instituem e mantêm (artigo 159, § $1^{\circ}$, combinado com o artigo 158, inciso I, ambos da Constituição Federal).

A regras de repartição dos recursos aos municípios estão previstas no artigo 91 do Código Tributário Nacional, o qual determina que: a) 10\% do total será direcionado aos municípios das capitais dos estados; e b) $90 \%$ para os demais municípios. Da parcela referente à alínea "a", ainda haverá uma partilha proporcional ao coeficiente individual de participação, obtido do produto da razão direta da população (percentual da população de cada município em relação à do conjunto das capitais) e da razão inversa da renda per capita do estado onde se localiza o município ${ }^{515}$. Da parcela relativa à alínea "b”, a distribuição observará coeficientes específicos de participação, conforme determinado no parágrafo segundo do mesmo artigo 91, do Código Tributário Nacional ${ }^{516}$.

Ao Tribunal de Contas da União (TCU) incumbe efetuar o cálculo do montante das receitas dos fundos de participação, o rateio entre os entes subnacionais integrantes do FPE e do FPM (artigo 161, da Constituição Federal) e a fiscalização da entrega dos mencionados recursos (artigo $1^{\circ}$, inciso VI, da Lei ${ }^{\circ} 8.443$, de 16 de julho de 1992).

515 O fator representativo do inverso da renda per capita do estado é calculado de acordo com o artigo 90 do Código Tributário Nacional.

516 O mencionado dispositivo estabelece uma divisão de categorias de municípios de acordo com o número de habitantes, atribuindo coeficientes específicos para cada uma deles: a) municípios de até 16.980 habitantes: i) pelos primeiros 10.188 , coeficiente de 0,6 ; ii) para cada 3.396 , ou fração excedente, mais 0,2; b) municípios acima de 16.980 até 50.940 habitantes: i) pelos primeiros 16.980 , coeficiente de 1,0; ii) para cada 6.792 ou fração excedente, mais 0,2 ; c) municípios acima de 50.940 até 101.880 habitantes: i) pelos primeiros 50.940, coeficiente de 2,0; ii) para cada 10.188 ou fração excedente, mais 0,2 ; d) municípios acima de 101.880 até 156.216 habitantes: i) pelos primeiros 101.880 , coeficiente de 3,0; ii) para cada 13.584 ou fração excedente, mais 0,2 ; e) acima de 156.216 habitantes, coeficiente de 4,0.

Há uma distribuição diversa para os municípios cuja população supere 156.216 habitantes. José Maurício Conti (Federalismo fiscal e fundos de participação. São Paulo: Editora Juarez de Oliveira, 2001, p. 94) esclarece: "O art. $2^{\circ}$ do Decreto-lei n. 1.881, de 27 de agosto de 1981, criou a Reserva do Fundo de Participação dos Municípios, destinada exclusivamente aos Municípios que se enquadrem no coeficiente de participação 4,0. Esta Reserva é constituída por 4,0\% (quatro por cento) dos recursos resultantes da parcela do FPM destinada aos Municípios 'do interior' (ou não-capital, como alguns autores preferem). Os Municípios que participarem dos recursos desta Reserva não sofrerão prejuízo quanto ao recebimento de sua parcela no FPM. A distribuição dos recursos da reserva é feita em conformidade com os critérios estabelecidos no parágrafo único do art. $3^{\circ}$ do Decreto-lei n. 1.881/81.

Assim, os municípios do 'interior' com mais de 156.216 (cento e cinqüenta e seis mil, duzentos e dezesseis) habitantes, além do valor da respectiva cota, passam a receber sua participação nesta Reserva prevista no Decreto-lei n. 1.881/81".

Para maiores detalhes sobre o FPM, ver José Maurício Conti (Federalismo fiscal e fundos de participação. São Paulo: Editora Juarez de Oliveira, 2001, pp. 91-95) e as Leis Complementares $n^{\circ} \mathrm{s} 62$, de 28/12/1989; 63, de 11/01/1990; 91, de 22/12/1997; e 106, de 23/03/2001. 


\subsubsection{Os fundos de participação e o desvio de recursos públicos no país}

Como afirmado anteriormente, os fundos de participação foram concebidos para diminuir as desigualdades existentes na federação, corrigindo os desequilíbrios vertical e horizontal. Vários fatores, no entanto, contribuem para que no Brasil tais pretensões não sejam alcançadas sequer em parâmetros regulares, proporcionando canais de estímulo para comportamentos caçadores de renda, clientelistas, patrimonialistas, bem como para atos de corrupção.

De fato, deve-se atentar que algumas características da federação contribuem para que se invertam os benefícios que poderiam advir da utilização dos fundos de participação.

O nível de descentralização no federalismo brasileiro é um desses aspectos, pois permite que grande poder, inclusive de recursos, permaneça em mãos do governo central, reduzindo a autonomia não apenas dos estados mas, principalmente, dos municípios. Isso faz com que muitos desses entes subnacionais passem a depender das transferências intergovernamentais - especialmente as originárias dos fundos de participação - para a própria manutenção e para fazer frente aos encargos que lhes incumbem.

Nesse aspecto, tanto estados quanto municípios são extremamente dependentes do repasse dos valores provenientes do FPE e do $\mathrm{FPM}^{517}$. Tal constatação é facilmente detectável em relação aos níveis de governo local. Após a Constituição Federal de 1988, não apenas diante da possibilidade de recebimento de transferências dos fundos de participação, mas também em razão da facilidade no procedimento de criação de novos municípios, um número significativo deles foi criado.

Importante lembrar que, antes do advento da atual Constituição, vigoravam os preceitos e requisitos da Lei Complementar Federal $n^{\circ} 1$, de 9 de novembro de 1967, que estabelecia os requisitos mínimos de população e renda pública para a criação de novos municípios. Dentre os requisitos existentes, havia a previsão de que a população estimada fosse superior a 10.000 habitantes ou não inferior a 5 milésimos da existente no respectivo estado, bem como a arrecadação, no último exercício, representasse 5 milésimos da receita estadual de impostos (artigo $2^{\circ}$, incisos I e IV).

517 Fernando Rezende. Brasil: conflitos federativos e reforma tributária. In: REZENDE, Fernando (coord.). Desafios do federalismo fiscal. Rio de Janeiro: Editora FGV, 2006, p. 95. No mesmo sentido, Flávio Azambuja Berti (Federalismo fiscal e defesa de direitos do contribuinte: efetividade ou retórica? Campinas: Bookseller, 2005, p. 154). 
A Constituição de 1988, porém, trouxe regras mais flexíveis, permitindo que a criação e o desmembramento de municípios ocorresse mediante lei estadual, obedecidos os requisitos contidos em lei complementar estadual (antiga redação do artigo $18, \S 4^{\circ}$, da Constituição Federal). Somente em momento posterior, por intermédio da Emenda Constitucional $\mathrm{n}^{\circ} 15$, de 1996, é que a redação do dispositivo foi alterada para permitir que a criação e o desmembramento de municípios fossem igualmente realizados por lei estadual, mas dentro de período determinado por lei complementar federal, após os estudos de viabilidade municipal apresentados e publicados na forma dessa lei.

Ocorre que no período entre a promulgação da atual Constituição e a Emenda Constitucional $n^{\circ} 15 / 96$ (que alterou a redação do artigo $18, \S 4^{\circ}$, da $\mathrm{CF}$ ) foi criado um grande número de municípios. Para se ter uma ideia desse incremento, no reduzido lapso temporal mencionado surgiram no estado de São Paulo mais de quarenta. A diferença impressiona quando se compara com a quantidade de municípios emancipados no mesmo estado em período anterior à atual Carta, ou seja, durante a vigência da Lei Complementar $\mathrm{n}^{\circ}$ 1/67: apenas um município ${ }^{518}$.

Os seguintes dados são categóricos: em 1980 existiam no Brasil 3.974 municípios; em 2007, esse número cresceu para 5.564, ou seja, no período foram instituídos 1590 municípios, representando um aumento de 40\%. Tomando-se como parâmetro o mesmo período, o índice de acréscimo nas Regiões do país foram os seguintes: a) Região Norte: de 153 para 449 municípios, um aumento de 193,5\%; b) Região Nordeste: de 1.375 para 1.793 , representando uma majoração de 30,4\%; c) Região Sudeste: de 1.410 para 1.668 municípios, um acréscimo de 18,3\%; d) Região Sul: de 719 para 1.188, indicando 65,2\% de aumento; e) Região Centro-Oeste: de 317 para 466 municípios, uma elevação de $47 \%$.

Não foi apenas a flexibilização dos requisitos e procedimentos que facilitou os acréscimos mencionados. A própria lógica de repartição dos recursos do FPM contribuiu para estimular o surgimento de novos municípios: são justamente aqueles que possuem

518 Maria Nazaré Lins Barbosa e Virgínia Talaveira Valentini Tristão. Federalismo, Clientelismo e Reforma Fiscal. In: Caderno de Pesquisas em Administração, São Paulo, v. 1, n. 8, $1^{\circ}$ trimestre de 1999, pp. 6465. Também disponível em www.ead.fea.usp.br/cad-pesq/arquivos/c8-Art6.pdf, acessado em 17.07.2008. Vale lembrar, ainda, que o artigo 96 do Ato das Disposições Constitucionais Transitórias convalidou os atos de criação e desmembramento de municípios "cuja lei tenha sido publicada até 31 de dezembro de 2006, atendidos os requisitos estabelecidos na legislação do respectivo Estado à época de sua criação" (alteração introduzida pela Emenda Constitucional n 57, de 2008).

519 O número de municípios no país, nos períodos indicados, foi obtido no site http://www.ibge.gov.br/brasil_em_sintese/tabelas/territorio.htm, acessado em 11.01.2010. A fonte dos dados, indicada no site, é IBGE, Diretoria de Geociências. 
menos habitantes os maiores beneficiados pelo Fundo de Participação dos Municípios. Nesse sentido, explicam Carlos Eduardo Gasparini e Fernando Andrés Blaco Cossio ${ }^{520}$ :

Além disso, as cotas do FPM são estabelecidas de acordo com faixas de população. Por exemplo, aos municípios com população de até dez mil habitantes é conferido o coeficiente de participação 0,6 . Isso significa que um município com quinhentos habitantes receberá o mesmo valor que outro de dez mil habitantes, o que acaba por gerar participações per capita muito díspares. Este é, provavelmente, um dos principais motores da 'febre' emancipatória, em que distritos com pequena população, sem condições mínimas e economias de escala adequada, transformam-se em municípios como forma de receber a cota mínima do FPM.

Tomem-se como exemplo dois municípios do Estado de Pernambuco. Petrolina tem uma população de 218 mil habitantes. Seu índice de condição de vida em 2000 era de 0,639 e sua receita de FPM em 2001 era de apenas R\$ 91 por habitante. No mesmo Estado de Pernambuco temos o micromunicípio de Itacuruba, com 3.600 habitantes, um Índice de Condição de Vida superior ao de Petrolina $(0,649)$ e com uma receita de FPM de R $\$ 470$ por habitante: cinco vezes mais do que recebia a cidade de Petrolina.

Outro exemplo interessante é o da cidade de Ribeirão das Neves, no Estado de Minas Gerais. Trata-se de uma cidade dormitório, nas franjas de Belo Horizonte, com alto índice de desemprego e violência e que dispõe de infra-estrutura urbana precária. É o caso típico de cidade que precisaria receber recursos do FPM, tanto porque não é capaz de gerar seus próprios recursos (não há indústrias e comércio no município) quanto pela grande população (246 mil habitantes) e pela expansão acelerada dessa população. Pois bem, este Município dispunha, em 2001, de apenas R 54 per capita de FPM, contra $\mathrm{R} \$ 1.807$ recebidos por Serra da Saudade (MG), com seus 873 habitantes e pressões muito menores para soluções de problemas públicos.

As observações acima podem ajudar a explicar o motivo pelo interesse no estabelecimento de novos municípios, inclusive com número de habitantes pouco expressivo, muitos dos quais sequer possuem escala suficiente para proporcionar serviços públicos $\operatorname{adequados}^{521}$.

A consequência imediata disso, além das já mencionadas, foi (e continua sendo) a sociedade ter de arcar com custos de instalação e manutenção de prefeituras, secretarias, câmaras municipais, pagamento a servidores, ou seja, despesas com o aparelhamento da máquina administrativa.

Existem, no entanto, outros efeitos permanentes e onerosos ao interesse público. Os fundos de participação (tanto o FPM quanto o FPE) são empregados no Brasil, na verdade, para a correção das falhas provocadas pelas fracas dimensões de descentralização do federalismo brasileiro, bem como para compensar a carência de autonomia dos entes

520 Transferências intergovernamentais. In: MENDES, Marcos (org.). Gasto público eficiente: 91 propostas para o desenvolvimento do Brasil. São Paulo: Instituto Braudel/Topbooks, 2006, pp. 187-188.

521 Marcos Mendes. Federalismo fiscal. In: ARVATE, Paulo; BIDERMAN, Ciro (org.). Economia do setor público no Brasil. Rio de Janeiro: Elsevier, 2004, p. 447. 
subnacionais, exercendo pouca influência no combate efetivo aos desequilíbrios regionais ${ }^{522}$. O efeito pérfido dessa utilização dos fundos, no entanto, é o desencorajamento à arrecadação de tributos próprios dos estados e municípios, bem como o estímulo ao aumento do gasto público ineficiente, terreno fértil para o desvio de recursos públicos.

De fato, se é verdade que tais transferências representam elemento relevante para a sobrevivência das entidades subnacionais e para a manutenção de sua relativa autonomia ${ }^{523}$, não menos verdade é que as esferas governamentais se sentem incentivadas a não exercer esforço fiscal para instituir e cobrar seus próprios tributos. Tal prática, contudo, acaba por reduzir cada vez mais a autonomia desses entes, os quais se habituam a exigir cada vez mais repasse por parte do governo central.

Perde-se, com isso, a relação entre o tributo e a provisão de bens públicos locais, prejudicando a aplicação do princípio do benefício e da função fiscal alocativa ${ }^{524}$. Prejudicase, igualmente, a possibilidade de visualização do tributo, impedindo que o contribuinte reconheça onde foi aplicado o produto da arrecadação para o qual colaborou.

A consequência disso é a incapacidade de responsabilizar o governante por eventual má utilização ou desvio dos recursos. Em outras palavras, a accountability resta inviabilizada, pois o mecanismo das transferências por meio de fundos facilita "a transferência de 'culpa' ou de créditos políticos" ${ }^{\text {,525. }}$.

A situação se agrava quando ocorre em locais ou estados nos quais as instituições não alcançaram um nível de fortalecimento considerável ${ }^{526}$. Nesse caso, torna-se comum o surgimento de condutas caçadoras de renda, bem como atos de clientelismo, patrimonialismo e corrupção, comportamentos esses que possuem como objetivo a busca de benefícios proporcionados pelos recursos dos fundos de participação.

522 Celina Souza (Redemocratização, federalismo e gasto social no Brasil: tendências recentes. Petrópolis (RJ), 23-27 out. 1999, XXIV Encontro Anual da Associação Nacionl de Pós-graduação em Ciências

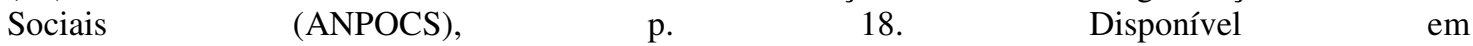
http://info.worldbank.org/etools/docs/library/232522/SouzaRedemocratizacao.pdf, acessado em 26.11.2009) ressalta que, "mesmo considerando a existência de mecanismos de compensação financeira como o FPE e o FPM, esses mecanismos têm tido, até agora, pouco efeito no sentido de minorar os desequilíbrios regionais".

523 Rogério Leite Lobo (Federalismo fiscal brasileiro: discriminação das rendas tributárias e centralidade normativa. Rio de Janeiro: Editora Lumen Juris, 2006, p. 153).

524 Vide item 1.6.1 do presente estudo.

525 Jonathan Rodden. Federalismo e descentralização em perspectiva comparada: sobre significados e medidas. Tradução de Miriam Adelman e Marta Arretche. In: Revista de Sociologia e Política, jun. 2005, n. 24, Curitiba, p. 21. Também disponível em http://www.scielo.br/scielo.php?pid=S010444782005000100003\&script=sci_arttext\&tlng=, acessado em 17.07.2008.

526 Sobre o papel das instituições no combate ao desvio de recursos públicos, vide item 3.7.2 do presente trabalho. 
A concentração de financiamento aos entes subnacionais por meio de fundos de participação produz outro efeito: o incentivo ao gasto público ineficiente. Consideração importante é feita, nesse sentido, por Carlos Eduardo Gasparini e Fernando Andrés Blanco $\operatorname{Cossio}^{527}$ :

Em primeiro lugar, as transferências estimulam a expansão do gasto público no Brasil. [...]

Em segundo lugar, as transferências provocam uma queda na qualidade do gasto. [...]

$\mathrm{O}$ que se constatou foi que à medida que aumenta a importância das transferências na receita municipal também aumentam as despesas de overhead e caem as despesas de infraestrutura e sociais. Ou seja, confirmam-se as previsões teóricas, (...) segundo as quais os burocratas e políticos locais utilizam as transferências recebidas para, prioritariamente, aumentar as despesas administrativas, que representam renda para eles próprios e para seus grupos de apoio.

Em terceiro lugar, mostrou-se que o esforço dos estados brasileiros para arrecadar ICMS cai à medida que aumenta a participação das transferências na receita estadual.

As despesas de overhead (custos fixos), mencionadas pelos autores, referem-se justamente aos gastos administrativos, significando que os recursos provenientes dos fundos de participação possuem utilização direcionada para fazer frente, principalmente, à manutenção e ao crescimento do aparato administrativo local ou regional ${ }^{528}$.

É o efeito flypaper (literalmente, "papel mata-moscas"), o qual significa que os recursos provenientes de transferências intergovernamentais incondicionais, como é o caso dos fundos de participação, propendem a ser destinados à expansão de gastos dos entes receptores, em vez de serem repartidos entre os contribuintes da jurisdição local, por meio da redução de tributos ${ }^{529}$. De acordo com Marcos Mendes, o termo flypaper é utilizado "em alusão à idéia de que o dinheiro 'gruda' onde esbarra primeiro (assim como as moscas grudam ao pousar nos papéis papa-moscas)", ou seja, "se o dinheiro entra na comunidade via

527 Carlos Eduardo Gasparini e Fernando Andrés Blanco Cossio. Transferências intergovernamentais. In: MENDES, Marcos (org.). Gasto público eficiente: 91 propostas para o desenvolvimento do Brasil. São Paulo: Instituto Braudel/Topbooks, 2006, p. 191.

528 Marcos Mendes (Federalismo fiscal. In: ARVATE, Paulo; BIDERMAN, Ciro (org.). Economia do setor público no Brasil. Rio de Janeiro: Elsevier, 2004, p. 447) ressalta que no ano de $200273 \%$ dos municípios brasileiros tiveram no mínimo $85 \%$ de suas receitas correntes financiadas por transferências intergovernamentais dos estados e da União.

529 Marcelo Piancastelli, Rogério Boueri e Edilberto Pontes Lima (Descentralização fiscal, harmonização tributária e relações intergovernamentais: como distintas federações reagem aos desafios da globalização. In: REZENDE, Fernando (coord.). Desafios do federalismo fiscal. Rio de Janeiro: Editora FGV, 2006, p. 75) sustentam que "o chamado flypaper effect sugere que os recursos provenientes de transferências são gastos com muito mais avidez e menos cuidado pelos governos subnacionais do que os recursos extraídos de seus próprios contribuintes. Argumenta-se que como tais recursos não têm correspondência no esforço de tributar sua população, a qualidade desse gasto tende a ser mais baixa do que o gasto realizado com receitas provenientes de tributação de seus contribuintes-eleitores. As transferências não condicionadas induziriam pois, segundo tal visão, ao aumento da ineficiência no gasto público". 
governo (como transferência) ele fica no governo", o que, no Brasil, representa "uma tendência à expansão do setor público sobre a economia, pois o dinheiro transferido transforma-se em despesa adicional e não em corte de impostos locais",530.

Surgem, com isso, problemas. Ao se dar prioridade a despesas com o crescimento do aparato governamental local ou regional, deixam-se de lado investimentos em infraestrutura, bem como dispêndios referentes à educação, saúde, saneamento, habitação etc. (gastos sociais). Ocorre que são exatamente os desembolsos à área de infraestrutura que fornecem condições para o desenvolvimento da região, aumentando o nível de emprego e fortalecendo o comércio local. Da mesma forma, os gastos sociais, principalmente os relacionados à saúde e à educação, promovem condições para a redução da pobreza.

O predomínio de gastos em demandas administrativas representa canal importante para desvio de recursos públicos, uma vez que essas despesas podem ser utilizadas para alimentar a lógica clientelista em busca de benefícios eleitorais aos governantes locais (nomeação de apadrinhados políticos em cargos de confiança na prefeitura, por exemplo).

Com grande quantidade de recursos à disposição de governantes locais e regionais, comportamentos rent-seeking são comuns e têm como objetivo o direcionamento desses valores à contratação de empresas (empreiteiras, inclusive) para a realização de obras públicas, cujo interesse público é duvidoso.

A conduta avança para a corrupção quando os valores provenientes dos fundos são utilizados para benefício próprio do governante ou de terceiros, sem destinação ao bem comum da população.

Todos esses atos são facilitados, conforme anteriormente explanado, pela impossibilidade de se implantar plenamente a accountability no caso dos fundos de participação, bem como diante da existência de nível fraco das instituições presentes em muitas localidades do país, principalmente naquelas onde a prática patrimonialista, clientelista ou até mesmo coronelista impera. Esses fatores, em conjunto, impedem ainda um efetivo controle da aplicação dos recursos pelos órgãos de fiscalização.

530 Marcos Mendes. Federalismo fiscal. In: ARVATE, Paulo; BIDERMAN, Ciro (org.). Economia do setor público no Brasil. Rio de Janeiro: Elsevier, 2004, pp. 451, 459. Em relação aos efeitos das transferências intergovernamentais sobre o tamanho do governo no país, ver Kelly Pereira Guedes e Carlos Eduardo Gasparini (Descentralização fiscal e tamanho do governo no Brasil. In: Economia Aplicada. Ribeirão Preto, v. 11, $\mathrm{n}^{\circ}$ 2, abr-jun de 2007, pp. 303-323. Também disponível em http://www.scielo.br/scielo.php?script=sci_arttext\&pid=S1413-80502007000200007\&lng=pt\&nrm=iso, acessado em 10.01.2010). 
O advento de uma maior descentralização, em todas as suas dimensões, reduziria a dependência excessiva de estados e municípios pelos recursos do fundo de participação e promoveria maiores níveis de accountability. De forma paralela, o fortalecimento das instituições é de vital importância para viabilizar qualquer nível de descentralização, sob pena de criação de caminhos fáceis para a corrupção e outros atos de desvio de recursos públicos.

Sem prejuízo, ou na hipótese de não se conseguir implementar uma política de maior descentralização, a federação poderia criar mecanismos legais e financeiros para incentivar a incorporação e fusão de municípios (artigo 18, § $4^{\circ}$, da Constituição Federal), com a finalidade de criar bases para que instituam seus tributos em escala suficiente para implementar suas próprias políticas e disponibilizar serviços públicos adequados à população.

Um dos estímulos para proporcionar a incorporação e fusão de municípios transitaria pela reformulação das regras de repartição do FPM e do FPE, que hoje beneficiam os municípios com menor número de habitantes, justamente aqueles que apresentam menor nível de eficiência na aplicação dos recursos. Existem estudos, por exemplo, que propõem uma forma de partilha com base em índices menos rígidos, estabelecendo critérios fundamentados na transparência, "capacidade tributária, esforço fiscal e necessidades de gastos dos entes subnacionais" $" 531$.

Outro aspecto importante seria a readequação das regras de utilização dos valores provenientes dos fundos, de forma a exigir dos entes subnacionais que a aplicação ocorra para o financiamento da infraestrutura local ou regional e para despesas de educação, saúde, saneamento etc., ou seja, gastos sociais. Todos esses dispêndios realmente promovem o desenvolvimento da região ${ }^{532}$ e criam bases mais favoráveis para a accountability e prevenção ao desvio de recursos. Aliás, a eficiência comprovada na aplicação em tais gastos - por intermédio de parâmetros objetivos (a melhoria no índice de desenvolvimento humano do município ou estado, por exemplo ${ }^{533}$ ) - poderia servir de parâmetro para a

531 Teresa Ter-Minassian. Brazil. In: TER-MINASSIAN, Teresa (edit.). Fiscal federalism in theory and practice. Washington: International Monetary Fund, 1997, p. 455.

532 Marcos Mendes (Capture of fiscal transfers: a study of Brazilian local governments. In: Economia Aplicada, Ribeirão Preto, v. 9, n. 3, jul-set de 2005, p. 441. Disponível em http://www.scielo.br/scielo.php?script=sci_arttext\&pid=S1413-80502005000300005\&lng=pt\&nrm=iso, acessado em 10.01.2010) ressalta que a captura de rendas é maior em áreas mais pobres.

533 O Tribunal de Contas da União, por intermédio do acórdão n ${ }^{\circ}$ 1120/2009 (relator Walton Alencar Rodrigues, Plenário, processo $n^{\circ}$ 003.430/2009-9, sessão de 27/05/2009), inclusive propôs ao Congresso Nacional que a partilha dos recursos do FPM levasse em conta, além do critério populacional, o índice 
disponibilização de mais recursos dos fundos de participação, fomentando a competição saudável entre os entes subnacionais.

\subsubsection{As transferências voluntárias e o desvio de recursos públicos}

As transferências voluntárias referem-se aos repasses de recursos de uma esfera da federação à outra, mediante compromisso (acordo, convênio ou cooperação financeira) entre os níveis governamentais. Em muitas dessas transferências não há finalidade específica para a utilização dos recursos repassados. As transferências podem ser dirigidas a entidades privadas sem fins lucrativos (Organizações Não Governamentais - ONG, por exemplo).

No caso da União, os recursos a serem destinados a estados, municípios e entidades privadas sem fins lucrativos devem ter previsão na lei orçamentária anual. O direcionamento dos recursos é feito mediante vinculação nominal desses entes ou entidades na proposta do Executivo ou na emenda ao orçamento. É possível, porém, que tal vinculação não se dê nominalmente aos agentes mencionados, mas os recursos serão a eles destinados se a programação orçamentária contemplar o encaminhamento de verbas para a região onde se localizam $^{534}$.

As transferências voluntárias da União, por estarem diretamente vinculadas à lei orçamentária anual, padecem dos mesmos males explicitados no item 4.5 do presente estudo, ou seja, sua utilização acaba provocando as seguintes consequências: a) uso das verbas para implantação de políticas pork-barrel; b) emprego de recursos para fins políticos e, muitas vezes, para projetos que não têm como finalidade o interesse nacional; c) utilização dos recursos, pelos parlamentares, para favorecimento de suas bases eleitorais; d) favorecimento à prática do lobby tanto na fase de inserção da previsão dos recursos na lei orçamentária anual, como também no ciclo da execução dessas transferências; e) uso, pelo poder central, da liberação das verbas objeto das transferências como instrumento de troca para a formação da coalizão do governo federal; f) quando incondicionais, as transferências voluntárias estão

de desenvolvimento humano dos respectivos municípios, a fim de que fossem aperfeiçoados os critérios dessa repartição.

534 Para mais informações sobre os procedimentos referentes às transferências voluntárias em que participa a União, bem como sobre a operacionalização dos convênios e contratos de repasse, ver Tribunal de Contas da União. Convênios e outros repasses. $2^{\mathrm{a}}$ ed. Brasília: Secretaria-Geral de Controle Externo, 2008. 
mais sujeitas ao efeito flypaper $^{535}$, o que provoca o dispêndio em gastos ineficientes ou para fins eleitorais, atraindo comportamentos caçadores de renda.

Todas as práticas acima mencionadas estimulam a criação e a perpetuação de políticas clientelistas, patrimonialistas, e até coronelistas, na federação brasileira. Além disso, o volume de recursos em jogo incentiva comportamentos rent-seeking para a obtenção de algum proveito na utilização dessas verbas ${ }^{536}$, podendo resultar, inclusive, em atos de corrupção.

Importante ressaltar que não somente as transferências oriundas do poder central é que incentivam os comportamentos já descritos. As provenientes de entes do mesmo nível, ou de estados para municípios, produzem as mesmas consequências.

Essas últimas, aliás, indicam claramente a utilização dos recursos para o alcance de benesses políticas entre os entes envolvidos, bem como para fins eleitorais. Nesses casos, aliás, mais uma vez o interesse público é afastado para ceder o caminho a práticas clientelistas. Deixa-se de aplicar recursos em projetos comuns dos entes federados, importantes para a sociedade, para utilizá-los em benefício de aliados; em outras situações, não se liberam as verbas com o objetivo de punir adversários políticos ${ }^{537}$.

535 Sobre a incidência do efeito flypaper nas transferências voluntárias, ver Ehtisham Ahmad e Jon Craig (Intergovernmental Transfers. In: TER-MINASSIAN, Teresa (edit.). Fiscal federalism in theory and practice. Washington: International Monetary Fund, 1997, pp. 82-83)

536 Motohiro Sato (The Political Economy of Interregional Grants. In: BOADWAY, Robin; SHAH, Anwar (edit.). Intergovernmental fiscal transfers: principles and practice. Washington: The World Bank, 2007, p. 183) estabelece uma relação importante entre o comportamento rent-seeking e a política pork-barrel. Assim explica o autor: "Os parlamentares federais exercem um ativo papel nas políticas pork barrel. Governos locais também podem empreender rent-seeking ou atividade de lobby para obter mais transferências. Eles forjam contatos com ministros responsáveis por transferências intergovernamentais. Seu mecanismo de pressão tem como objetivo políticos eleitos em suas regiões. De sua parte, políticos se engajam em políticas pork-barrel. Dessa forma, rent-seeking e políticas pork-barrel caminham juntas. (...)". Tradução livre do autor. No original: "Central legislators play an active role in pork barrel politics. Local governments may also undertake rent-seeking ou lobbying activities in order to obtain more transfers. They forge contacts with the central ministries in charge of interregional grants. Their lobbying my target politicians elected from their regions. For their part, politicians engage in pork barrel politics. Thus rent seeking and pork barrel politics are tied together. (...)".

537 Sobre essa questão, interessante material foi publicado no Jornal Valor Econômico (Cristiane Agostine e Marta Watanabe. "Aliados recebem mais transferências: Capitais governadas por aliados de governadores recebem mais repasses voluntários", 24/03/2008, p. A-8). Eis alguns trechos da matéria: "A parceria entre o governador de Minas Gerais, Aécio Neves (PSDB), e o prefeito de Belo Horizonte, Fernando Pimentel (PT), em torno do lançamento de uma candidatura única na capital mineira está estampada no volume das transferências voluntárias do governo estadual para o municipal. Crescentes, desde 2004, as transferências deram um salto na previsão orçamentária de 2008. O governo tucano de Aécio deve repassar voluntariamente para a administração petista de Pimentel R 81 milhões este ano, quatro vezes o valor de 2004, ano das últimas eleições municipais. 
As medidas já referidas em tópicos anteriores, voltadas à maior descentralização dos entes subnacionais - aumentando assim suas respectivas autonomias - e ao fortalecimento das instituições locais, já reduziriam a necessidade de transferências voluntárias.

De qualquer forma, as regras referentes a essas transferências voluntárias necessitam ser modificadas para atender o interesse público. Uma dessas alterações poderia se consubstanciar na proibição de transferências incondicionadas, de forma a exigir que os entes governamentais participantes demonstrassem a viabilidade de projetos comuns entre eles, bem como o atendimento aos objetivos especificados no convênio ou no acordo de cooperação. Reduzir-se-ia, dessa forma, a utilização dos recursos para fins eleitorais ou clientelistas.

Outro fator importante que promoveria inclusive uma maior accountability em relação às transferências voluntárias seria a participação direta da população na definição das prioridades locais e nas decisões para aplicação dos recursos. Nos municípios, essa medida é

Levantamento do Valor em 12 capitais brasileiras mostrou que em pelo menos oito delas a alternância entre aliados e adversários no governo do Estado e na administração das capitais afeta fortemente as transferências, quase sempre atreladas a convênios para execução de projetos ou obras.

O exemplo mais eloqüente é São Paulo. Em 2004, quando a prefeitura era ocupada por Marta Suplicy (PT) e o Palácio dos Bandeirantes, por Geraldo Alckmin (PSDB), as transferências do Estado para a capital somaram R\$ 44 milhões. Este ano [2008], o orçamento estadual prevê que o governador José Serra (PSDB) transfira para seu aliado Gilberto Kassab (DEM) 16 vezes o que foi transferido quatro anos atrás, chegando a R $\$ 724$ milhões. Esta soma também é muito superior aos repasses nos quase dois anos em que Alckmin e Serra fizeram dobradinha nos governos estadual e municipal (...).

'Temos uma situação muito diferente agora. Houve um amadurecimento dos projetos', conta o secretário de Finanças do município de São Paulo, Walter Aluisio Rodrigues. Ele não nega que haja conotação política na transferência de recursos, mas prefere citar os entraves burocráticos. (...)

Assim como em São Paulo e Belo Horizonte, nas prefeituras de Fortaleza, Florianópolis e Aracaju os repasses voluntários ficaram afinados com os investimentos municipais concentrados às vésperas das eleições. [...]

Quando foi idealizada, a transferência voluntária era destinada a projetos de interesse e responsabilidade comum entre Estados e municípios. (...)

Mas a prática é outra. 'Existe a necessidade de dar atendimento político aos aliados', avalia François Bremaeker, coordenador do Instituto Brasileiro de Administração Municipal (Ibam). 'Não é um fator que possa ser recriminado, é uma prática disseminada em campanhas'. [...]

As transferências voluntárias dos Estados também minguaram em Goiânia e Teresina, pela falta de afinidade entre os grupos políticos dos governos municipal e estadual.

A rivalidade entre o prefeito de Goiânia, Íris Rezende (PMDB), e o governador do Estado, Alcides Rodrigues (PP), esvaziou as transferências voluntárias. (...)

Teresina também registra transferências voluntárias nulas desde 2004. É a mesma aliança de Minas, com os partidos trocados. Daquele ano até hoje a prefeitura da capital e o comando do Estado ficaram, respectivamente, nas mãos do PSDB e PT. Para o secretário de Finanças de Teresina, Felipe Mendes, a rivalidade entre governador e prefeito explica em parte a falta de transferências não-obrigatórias.

'O PT e o PSDB não são partidos amigos. Então não há repasses voluntários. Além disso, as transferências do Estado costumam privilegiar as cidades do interior e não a capital', diz. Segundo Mendes, o município e o governo estadual têm alguns projetos em parceria, mas são 'projetos em que cada um faz a sua parte'. [...]". 
viável e salutar, pois incita os cidadãos a participarem das políticas públicas e promove o interesse na fiscalização da destinação das verbas transferidas. 


\section{CONCLUSÃO}

Do trabalho acima desenvolvido pode-se extrair algumas conclusões referentes ao federalismo fiscal brasileiro e ao desvio de recursos, expostas nos seguintes tópicos:

1. O federalismo fiscal se preocupa com a análise de quais funções ou atribuições necessitam ser centralizadas ou descentralizadas na federação e em quais níveis isso deve ocorrer, tudo para o alcance de uma maior eficiência na satisfação das necessidades públicas.

2. Os fundamentos do federalismo fiscal baseiam-se nos princípios do benefício (atribuição da prestação de serviços públicos entre entes federados de acordo com a amplitude ou especificidade da demanda), da compensação fiscal (encarregada de corrigir externalidades positivas ou negativas) e da distribuição centralizada (direcionamento das políticas de redistribuição de rendas em mãos do poder central).

3. Referidos princípios possuem estreita relação com as funções fiscais alocativa (referente ao poder de indicar a alocação de recursos), distributiva (relacionada à forma de organizar a distribuição de renda no país) e a função estabilizadora (referente à maneira de assegurar a estabilização econômica).

4. O perfeito ajuste entre as funções fiscais é difícil de se concretizar, tendo em vista a existência de possíveis incorreções no planejamento fiscal dos Estados, bem como em razão de padrões imperfeitos de competitividade e cooperação nas relações fiscais entre os entes federativos.

5. A existência de falhas no ajuste das funções fiscais pode ajudar a compreender se, sob a ótica fiscal, a descentralização do Estado sob a forma federativa é capaz de estimular, encobrir ou evitar o desvio de recursos públicos, principalmente por intermédio de comportamentos ou práticas como o rent-seeking, patrimonialismo, clientelismo, coronelismo e corrupção.

6. O rent-seeking ou captação do Estado representa a conduta de certos agentes para obter ou manter vantagens, privilégios ou rendas proporcionados pelo Estado. O patrimonialismo refere-se à utilização do aparelhamento estatal para a busca de benefícios particulares. A dependência política e econômica em troca de voto ou apoio eleitoral constitui as bases do clientelismo. O sistema político surgido no Brasil na época da Primeira República e que representava o domínio político privado exercido pelos possuidores de terras 
(os "coronéis"), dando ensejo ao direcionamento de votos, é denominado "coronelismo" e ainda persiste em alguns locais do país. Conceitua-se a corrupção como o ato contrário ao ordenamento jurídico, praticado por agente público, com o fim de patrocinar interesse próprio ou de terceiros.

7. As formas de conduta e práticas acima descritas exercem influência direta no bom exercício das funções fiscais, dificultando a distribuição de renda e riqueza, impedindo a alocação eficiente de recursos públicos e criando obstáculos à estabilização da economia.

8. Com a finalidade de avaliar o impacto que o federalismo exerce no desvio de recursos públicos, deve-se atentar ao estudo de cada uma das perspectivas ou dimensões da descentralização (política, fiscal, de políticas), a fim de verificar como atuam no incentivo ou no combate ao desencaminhamento de recursos. No tocante à descentralização fiscal, devese avaliar, ainda, o grau de autonomia entregue aos entes subnacionais.

9. A federação brasileira, desde o seu nascedouro, apresentava forte concentração de poder em mãos do governo central (União). Com o advento da Constituição Federal de 1988, pretendeu-se implementar maior nível de descentralização fiscal, o que, porém, por ausência de planejamento, não veio acompanhado de outras dimensões de descentralização (como a de repartição equilibrada de encargos entre os entes subnacionais). Tal fato obrigou a União a se valer de artifícios para aumentar sua arrecadação, provocando não apenas o aumento da carga tributária e a rigidez orçamentária, mas também a quase nulidade dos efeitos da descentralização fiscal contida na atual Carta, reduzindo ainda mais a autonomia de estados e municípios. Esses fatores fizeram com que o direcionamento de recursos e políticas se concentrasse em mãos do governo central, favorecendo o surgimento de práticas clientelistas e atos de corrupção envolvendo a União e as demais esferas governamentais.

10. O controle do endividamento dos entes subnacionais, proporcionado pela Lei de Responsabilidade Fiscal, embora tenha surgido como importante elemento para afastar comportamentos de indiferença e imprudência fiscais dos entes da federação, aumentou ainda mais a dependência dos estados e municípios por recursos do governo central.

11. A ausência de uma efetiva descentralização política na federação, que dê oportunidade aos entes subnacionais de adotarem postura administrativa, política e financeira flexível, de acordo com suas reais necessidades regionais, tolhe a plena autonomia desses entes. 
12. A discrepância da representação dos estados no Congresso Nacional, ou seja, a sub-representação de estados com maior número de eleitores e economicamente fortes em face da super-representação de estados com menor quantidade de eleitores e de pouca reputação econômica, restringe o poder da maioria democrática (demos constraining). Tal concentração de poder justamente em mãos dos estados menos desenvolvidos, nos quais não há instituições fortes, longe de solucionar as desigualdades regionais, representa campo fértil para o surgimento de comportamentos caçadores de renda, clientelistas e atos de corrupção.

13. A competição vertical (exercida entre níveis governamentais diferentes), inclusive aquela referente ao estabelecimento de políticas, produz efeitos contrários à finalidade do federalismo, impedindo níveis de accountability (responsabilização da autoridade pela administração dos recursos públicos e pela prestação de contas à população) eficazes e impossibilitando a qualidade do gasto público. Essas características abrem oportunidade para atos de desvio de recursos. A aprovação da lei complementar a que se refere o artigo 23, parágrafo único, da atual Constituição Federal, poderia viabilizar o planejamento, a cooperação e a coordenação entre os entes da federação, diminuindo as consequências da competição vertical.

14. A competição horizontal (exercida entre esferas governamentais de mesmo nível) promove a cultura da accountability e mecanismos para a redução da corrupção e do rentseeking. A relativa autonomia dos municípios e sua dependência por recursos dos entes federados de nível superior impedem, porém, a efetivação da mencionada competição. No âmbito dos estados, a concorrência horizontal ocorre, mas sob base tributária inadequada (o imposto sobre operações relativas à circulação de mercadorias e sobre prestações de serviços de transporte interestadual e intermunicipal e de comunicação - ICMS), gerando "guerra fiscal" entre esses entes, tornando ineficazes a função alocativa e o princípio do benefício e, ainda, atraindo comportamento caçador de renda, clientelismo e corrupção.

15. A constatação do quanto acima apontado em relação às falhas do federalismo fiscal brasileiro e suas consequências para o desvio de recursos pode ser verificada por intermédio da análise dos aspectos que envolvem a lei orçamentária anual federal, bem como as transferências intergovernamentais provenientes de fundos de participação e de transferências voluntárias.

16. Na proposta de lei orçamentária anual, o Congresso Nacional possui poderes para apresentar emendas de despesas ao projeto; no entanto, tais emendas são utilizadas para 
projetos eleitorais dos parlamentares, os quais acabam privilegiando suas bases eleitorais com o direcionamento dos recursos públicos (política pork-barrel). Essa prática favorece o clientelismo e o surgimento da corrupção, situações que poderiam ser evitadas mediante uma maior descentralização em todas as suas dimensões, dispensando-se a utilização de emendas ao orçamento e encarregando os parlamentares da análise de questões de interesse nacional. Sem prejuízo, uma política de maior transparência, clareza, objetividade e acesso à população seria salutar para democratizar o procedimento de emendas ao orçamento.

17. O incentivo a práticas de desvios de recursos não ocorre apenas no procedimento de emendas ao orçamento, mas também nas fases da apresentação da proposta de lei orçamentária pelo Poder Executivo e da execução orçamentária (liberação dos recursos objeto das emendas). Nessas situações, o lobby (atuação organizada de grupos de pressão), inclusive de empreiteiras, é exercido de forma ativa na busca de interesses particulares, sem a preocupação com o interesse nacional, muitas vezes desembocando em atos de corrupção.

18. A previsão de emendas ao orçamento é utilizada pelo Poder Executivo federal como instrumento de barganha, isto é, como "moeda de troca" para formar seu governo de coalizão e obter votação favorável aos seus projetos no Congresso Nacional. Esse poder é exercido por intermédio do veto do Presidente da República às emendas ou pelo controle na liberação dos respectivos recursos. Tais fatos indicam que é o Poder Executivo que, na verdade, exerce a maior influência sobre o orçamento, controlando a maioria dos procedimentos referentes à proposição e execução da lei orçamentária anual.

19. Os fundos de participação dos estados e municípios, da forma como se encontram estruturados, não são eficazes para diminuir os desequilíbrios vertical e horizontal da federação. São, na verdade, empregados na correção de falhas provocadas pelas inexpressivas dimensões de descentralização do federalismo brasileiro, assim como para compensar a carência de autonomia dos entes subnacionais.

20. O exagerado financiamento de estados e municípios por intermédio dos fundos de participação reduz o nível de accountability em relação à aplicação dos recursos e faz com que os mencionados entes não exerçam o esforço fiscal suficiente para instituir e cobrar seus próprios tributos; além disso, acabam aplicando os recursos provenientes dos fundos para alimentar a própria máquina administrativa local, criando canais de estímulo a comportamentos caçadores de renda, patrimonialistas, clientelistas, bem como a atos de corrupção. 
23. Dentre as sugestões para inverter a situação provocada pelos fundos de participação, podem ser mencionadas: a) o estabelecimento de maior autonomia aos entes subnacionais; b) a criação de incentivos à incorporação e fusão de municípios; c) a reformulação das regras dos fundos, com a finalidade de inserir parâmetros eficazes de repartição, de impor destinação ao emprego dos recursos, bem como de estabelecer metas de qualidade na aplicação dos gastos.

24. As transferências voluntárias estão sujeitas aos mesmos males referentes aos fundos de participação. Quando realizadas entre estados e municípios, na maioria das vezes possuem conotação política, ou seja, a liberação de verbas pelos estados ocorre com o intuito de favorecer aliados, com a pretensão de atingir fins eleitorais. Além das sugestões dirigidas aos fundos, o mecanismo das transferências voluntárias deveria ser alterado para contemplar apenas repasses condicionados. Uma maior participação da população na definição de prioridades e políticas facilitaria a accountability e evitaria atos de desvio de recursos.

25. Diante do que foi até aqui mencionado, pode-se depreender que a Constituição Federal de 1988 não foi capaz de elaborar mecanismos eficientes para a diminuição das desigualdades regionais, de criar condições favoráveis para outorgar ao governo central o papel de coordenador e equalizador dos conflitos federativos, bem como de conceber estruturas adequadas para reduzir os incentivos ao desvio de recursos públicos. Como visto, dois fatores foram fundamentais para que tais implicações ocorressem: a) a maneira como as dimensões de descentralização (fiscal, política e de políticas) se estruturaram no Brasil; b) o estabelecimento de algumas perspectivas da descentralização sem o necessário e concomitante fortalecimento das instituições no país, prejudicando a accountability, a governança e o controle.

26. Deve-se repensar o federalismo por meio da reavaliação de todas as dimensões da descentralização, entregando-se ao governo central condições e poderes para, efetivamente, coordenar, planejar e programar projetos nacionais para o país, juntamente com a cooperação dos demais entes federados. Tais modificações requerem, juntamente, alterações nos sistemas eleitoral e político, a fim de se evitar maiores estímulos à prática de desvios de recursos.

27. A reavaliação das perspectivas da descentralização deve estar conjugada com o fortalecimento das instituições do país, a fim de permitir maiores graus de accountability, bem como deve considerar uma melhor inter-relação entre os órgãos de controle no combate 
ao desvio de recursos. Cabe a esses mesmos órgãos a função de incentivar e fomentar a fiscalização da atividade financeira por parte da população (controle social), inclusive no âmbito dos governos locais. 


\section{BIBLIOGRAFIA}

ABBAGnANO, Nicola. Dicionário de filosofia. Tradução de Alfredo Bosi e Ivone Castilho Benedetti. $5^{\mathrm{a}}$ ed. São Paulo: Martins Fontes, 2007. Título original: Dizionario di Filosofia.

ABRANCHES, Sérgio Henrique Hudson de. A democracia brasileira vai bem, mas requer cuidados: proposições sobre democracia brasileira e o presidencialismo de coalizão. Estudos e pesquisas $\mathrm{n}^{\circ}$ 5, XIII Fórum Nacional, Rio de Janeiro, maio 2001, INAE Instituto Nacional de Altos Estudos, pp. 1-18. Disponível em www.forumnacional.org.br/trf_arq.php?cod=EP00050, acessado em 30.11.2009.

Presidencialismo de coalizão. O dilema institucional brasileiro. In: Dados Revista de Ciências Sociais. Rio de Janeiro, v. 31, n. 1, 1988, pp. 5-38.

AHMAD, Ehtisham e CRAIG, Jon. Intergovernmental Transfers. In: TER-MINASSIAN, Teresa (edit.). Fiscal federalism in theory and practice. Washington: International Monetary Fund, 1997, p. 73-107.

ALBUQUERQUE, Claudiano; MEDEIROS, Márcio; FEIJÓ, Paulo Henrique. Gestão de finanças públicas: fundamentos e práticas de planejamento, orçamento e administração financeira com responsabilidade fiscal. $2^{\mathrm{a}}$ ed. Brasília: Editora Gestão Pública, 2008.

ALMEIDA, Guilherme Assis de; CHRISTMANN, Martha Ochsenhofer. Ética e direito: uma perspectiva integrada. São Paulo: Atlas, 2002.

ANDRADE, Eduardo de Carvalho. Externalidades. In: ARVATE, Paulo; BIDERMAN, Ciro (org.). Economia do setor público no Brasil. Rio de Janeiro: Elsevier, 2004, p. 16-33.

ANDRADE, Sudá de. Apontamentos de ciência das finanças. $2^{\mathrm{a}}$ ed., ampl. e atual. Rio de Janeiro: José Konfino Editor, 1966.

ARAÚJO, Edmir Netto de. Curso de direito administrativo. $3^{\mathrm{a}}$ ed. rev., ampl. e atual. São Paulo: Saraiva, 2007.

ARIKAN, Guzin Gulsun. Fiscal Decentralization: A Remedy for Corruption? In: International Tax and Public Finance, mar. 2004, v. 11, n. 2, Kluwer Academic Publishers, pp. 175-195. 
ARRETCHE, Marta. Federalismo. In: AVRITZER, Leonardo; ANASTASIA, Fátima (org.). Reforma política no Brasil. Belo Horizonte: Editora UFMG, 2006, pp. 123127.

ARVATE, Paulo; BIDERMAN, Ciro; MENDES, Marcos. Aprovação de empréstimos a governos subnacionais no Brasil: há espaço para comportamento político oportunista? In: Revista de Ciências Sociais, Rio de Janeiro, v. 51, n. 4, 2008, pp. 983-1014.

ATALIBA, Geraldo. República e Constituição. $2^{\mathrm{a}}$ ed. atual. Rosolea Miranda Folgosi. São Paulo: Malheiros Editores, 2001.

Apontamentos de ciência das finanças, direito financeiro e tributário. São Paulo: Editora Revista dos Tribunais, 1969.

BALEEIRO, Aliomar. Cinco aulas de finanças e política fiscal. $2^{\mathrm{a}}$ ed. rev. São Paulo: José Bushatsky Editor, 1975.

. Uma introdução à ciência das finanças. $16^{\mathrm{a}} \mathrm{ed}$. rev. e atual. por Dejalma de Campos. Rio de Janeiro: Forense, 2004.

BARBOSA, Maria Nazaré Lins; TRISTÃO, Virgínia Talaveira Valentini. Federalismo, Clientelismo e Reforma Fiscal. In: Caderno de Pesquisas em Administração, São Paulo, v. 1, n. 8, $1^{\circ}$ trimestre de 1999, pp. 61-68. Também disponível em www.ead.fea.usp.br/cad-pesq/arquivos/c8-Art6.pdf, acessado em 17.07.2008.

BARDHAN, Pranab. Decentralization of Governance and Development. In: The Journal of Economic Perspectives, v. 16, n. 4, outono 2002, American Economic Association, p. 185-205. Disponível em http://www.jstor.org/stable/3216920, acessado em 04.12.2009.

BASTOS, Celso Ribeiro. Curso de Teoria do Estado e Ciência Política. $6^{\text {a }}$ ed. São Paulo: Celso Bastos Editora, 2004.

BERCOVICI, Gilberto. Dilemas do Estado Federal Brasileiro. Porto Alegre: Livraria do Advogado Editora, 2004.

BERTALANFFY, Ludwig Von. Teoria geral dos sistemas. Tradução de Francisco M. Guimarães. 2a ed. Petrópolis: Editora Vozes, 1975. Título original: General systems theory. 
BERTI, Flávio Azambuja. Federalismo fiscal e defesa de direitos do contribuinte: efetividade ou retórica? Campinas: Bookseller, 2005.

BEZERRA, Marcos Otávio. Corrupção: um estudo sobre poder público e relações pessoais no Brasil. Rio de Janeiro: Relume-Dumará, ANPOCS, 1995.

Em nome das "bases": política, favor e dependência pessoal. Rio de Janeiro: Relume Dumará/Núcleo de Antropologia da Política, 1999.

BIROU, Alain. Dicionário das ciências sociais. Tradução de Alexandre Gaspar, Isabel Madureira Pinto, Linda Xavier e Maria Manuela Meneses. $3^{\text {a }}$ ed. Lisboa: Publicações Dom Quixote, 1977. Título Original: Vocabulaire Pratique des Sciences Sociales.

BLANCHARD, Olivier J.; SHLEIFER, Andrei. Federalism with and without political centralization. China versus Russia. Fev. 2000. MIT Dept. of Economics Working Paper n. 00-15; Harvard Institute of Economics Research Paper n. 1889. Disponível em http://ssrn.com/abstract=236127, acessado em 16.07.2008.

BOADWAY, Robin; SHAH, Anwar. Fiscal federalism: principles and practices of Multiorder Governance. New York: Cambridge University Press, 2009.

BOBBIO, Norberto. Estado, governo, sociedade: para uma teoria geral da política. $10^{\mathrm{a}}$ ed. Tradução de Marco Aurélio Nogueira. São Paulo-Rio de Janeiro: Paz e Terra, 2003.

BOFF, Salete Oro. Reforma tributária e federalismo: entre o ideal e o possível. Porto Alegre: Sergio Antonio Fabris Editor, 2005.

BONAVIDES, Paulo. Ciência política. 10ª ed. rev. e atual. São Paulo: Malheiros, 2004. Curso de direito constitucional. 15ª ed. atual. São Paulo: Malheiros, 2004.

BORSANI, Hugo. Relações entre política e economia: Teoria da Escolha Pública. In: ARVATE, Paulo; BIDERMAN, Ciro (org.). Economia do setor público no Brasil. Rio de Janeiro: Elsevier, 2004, pp. 103-125.

BUJANDA, Fernando Sainz de. Lecciones de Derecho Financiero. $7^{\mathrm{a}}$ ed. Madri: Universidad Complutense/Facultad de Derecho, 1989.

CAMARGO, Guilherme Bueno de. A guerra fiscal e seus efeitos: autonomia $\mathrm{x}$ centralização. In: CONTI, José Mauricio (org.). Federalismo fiscal. Barueri: Manole, 2004, pp. 191-222. 
CARVALHO, F. J. C. de et al. Economia monetária e financeira. Rio de Janeiro: Campus, 2000.

CARVALHO, José Augusto Moreira de. As parcerias público-privadas e a atividade financeira do Estado. Dissertação de Mestrado. São Paulo: Universidade de São Paulo - Faculdade de Direito, 2006.

Aspectos gerais e controvertidos das contribuições especiais. In: Revista Tributária e de Finanças Públicas. São Paulo, ano 13, jan-fev de 2005, n. 60, Academia Brasileira de Direito Tributário (ABDT), Editora Revista dos Tribunais, p. $56-92$.

Do exercício financeiro. In: CONTI, José Mauricio (coord.). Orçamentos públicos: a Lei 4.320/1964 comentada. São Paulo: Editora Revista dos Tribunais, 2008, pp. 121-133.

. Introdução à Teoria dos Jogos no Direito. In: Revista de Direito Constitucional e Internacional. Ano 15, n. 59, abr-jun de 2007, São Paulo, Editora Revista dos Tribunais/Instituto Brasileiro de Direito Constitucional - IBDC, p. 213-234.

CARVALHO, José Murilo de. Mandonismo, Coronelismo, Clientelismo: Uma Discussão Conceitual. In: Dados - Revista de Ciências Sociais. Rio de Janeiro, v. 40, n. 2, 1997. Disponível em http://www.scielo.br/scielo.php?script=sci_arttext\&pid=S0011$52581997000200003 \& \operatorname{lng}=$ pt\&nrm=iso, acessado em 04.08.2009.

CARVALHO, Márcio André de. How logrolling can explain the failure of the government coalition in Brazil. In: Revista de Administração Pública, Rio de Janeiro, v. 40, n. 5, set-out de 2006, pp. 865-882. Disponível em http://www.scielo.br/scielo.php?script=sci_arttext\&pid=S0034$76122006000500006 \& \operatorname{lng}=$ pt\&nrm=iso, acessado em 04.01.2010.

CAVALCANTI, Themistocles Brandão. Teoria do Estado. Rio de Janeiro: Editor Borsoi, 1958.

CINTRA, Antônio Octávio. Presidencialismo e parlamentarismo: são importantes as instituições? In: AVELAR, Lúcia; CINTRA, Antônio Octávio (org.). Sistema político brasileiro: uma introdução. $2^{\mathrm{a}}$ ed. Rio de Janeiro: Konrad-AdenauerStiftung; São Paulo: Editora Unesp, 2007, pp. 35-58. 
COELHO, Luiz Fernando. Teoria da Instituição. In: FRANÇA, R. Limongi (coord.). Enciclopédia Saraiva do Direito. São Paulo: Saraiva, 1980, v. 44, pp. 511-518.

COMPARATO, Fábio Konder. A afirmação histórica dos direitos humanos. $3^{\mathrm{a}}$ ed. rev. e ampl. São Paulo: Saraiva, 2003.

CONTI, José Maurício. A autonomia financeira do poder judiciário. São Paulo: MP Editora, 2006.

Arts. 32 a 39. In: MARTINS, Ives Gandra da Silva; NASCIMENTO, Carlos Valder do (org.). Comentários à Lei de Responsabilidade Fiscal. São Paulo: Saraiva, 2001, p. 217-246.

Da elaboração da Lei de Orçamento. In: CONTI, José Mauricio (coord.). Orçamentos públicos: a Lei 4.320/1964 comentada. São Paulo: Editora Revista dos Tribunais, 2008, pp. 115-120.

Da proposta orçamentária: Da elaboração da proposta orçamentária. In: CONTI, José Mauricio (coord.). Orçamentos públicos: a Lei 4.320/1964 comentada. São Paulo: Editora Revista dos Tribunais, 2008, pp. 93-100. Federalismo fiscal e fundos de participação. São Paulo: Juarez de Oliveira, 2001.

COULANGES, Fustel de. A cidade antiga: estudos sobre o culto, o direito, as instituições da Grécia e de Roma. Tradução de Jonas Camargo Leite e Eduardo Fonseca. São Paulo: Hemus, 1975. Título original: La cité antique: étude sur le culte, le droit, les institutions de la Grece et de Rome.

CROWTER, Jonathan (edit.). Oxford Advanced Learner's Dictionary of Current English. $5^{\mathrm{a}}$ ed. Oxford: Oxford University Press, 1995.

DALLARI, Dalmo de Abreu. Elementos de teoria geral do Estado. 24a ed. São Paulo: Saraiva, 2003.

DALTON, Hugh. Princípios de finanças públicas. Tradução de Maria de Lourdes Modiano. $4^{\mathrm{a}}$ ed. Rio de Janeiro: FGV, 1980. Título original: Principles of public finance.

DE PLÁCIDO E SILVA. Noções de finanças e direito fiscal. $2^{\mathrm{a}}$ ed. Curitiba/São Paulo/Rio de Janeiro: Editora Guairá, 1941. 
DEL MONTE, Alfredo; PAPAGNI, Erasmo. The determinants of corruption in Italy: Regional panel data analysis. In: European Journal of Political Economy, Forthcoming, 24 maio 2006. Disponível em: http://ssrn.com/abstract=903991, acessado em 16.07.2008.

DIXIT, Avinash K.; NALEBUFF, Barry J. Pensar estratégicamente: un arma decisiva em los negócios, la política y la vida diaria. Tradução de Ana Varela e Alicia Valls. Barcelona: Antoni Bosch, 1992. Título original: Thinking Strategically. The Competitive Edge in Business, Politics and Everyday Life.

DOLHNIKOFF, Miriam. O pacto imperial: origens do federalismo no Brasil do século XIX. São Paulo: Globo, 2005.

DOROTISNSKY, William e PRADHAN, Shilpa. Exploring Corruption in Public Financial Management. In: CAMPOS, J. Edgardo e PRADHAN, Sanjay (edit.). The many faces of corruption: tracking vulnerabilities at the sector level. Washington: The World Bank, 2007, p. 267-294.

DUGUIT, Léon. Fundamentos do direito. Tradução de Ricardo Rodrigues Gama. Campinas: LZN Editora, 2003.

EISENSTADT, S. N. e RONIGER, Louis. Patron-Client Relations as a Model of Structuring Social Exchange. In: Comparative Studies in Society and History, v. 22, $\mathrm{n}^{\circ}$ 1, jan. 1980, Cambridge University Press, pp. 42-77.

ELALI, André. O federalismo fiscal brasileiro e o sistema tributário nacional. São Paulo: MP Editora, 2005.

ELLIOT, Kimberly Ann. Introdução. In: ELLIOT, Kimberly Ann. A corrupção e a economia global. Tradução de Marsel Nascimento Gonçalves de Souza. Brasília: Editora Universidade de Brasília, 2002, p. 17-23. Título original: Corruption and the global economy.

A corrupção como um problema de legislação internacional: recapitulação e recomendações. In: ELLIOTT, Kimberly Ann (org.). A corrupção e a economia global. Tradução de Marsel Nascimento Gonçalves de Souza. Brasília: Editora Universidade de Brasília, 2002, pp. 255-339. Título original: Corruption and the global economy. 
ENIKOLOPOV, Ruben e ZHURAVSKAYA, Ekaterina. Decentralization and political institutions. In: Jounal of Public Economics, v. 91, nº 11-12, Elsevier, dez. 2007, pp. 2261-2290.

FAZZIO JÚNIOR, Waldo. Corrupção no poder público: peculato, concussão, corrupção passiva e prevaricação. São Paulo: Atlas, 2002.

FEDERAÇÃO DAS INDÚSTRIAS DO ESTADO DE SÃO PAULO (FIESP), "Relatório Corrupção: custos econômicos e propostas de combate", São Paulo, 5 dez. 2006. Disponível em http://bvc.cgu.gov.br/handle/123456789/937, acessado em 28.11.2008.

FERREIRA, José Eugénio Dias. Tratado de finanças públicas: doutrina e legislação portuguesa. Lisboa: Ramos, Afonso \& Moita, Lda., 1950, v. 2.

FERREIRA FILHO, Manoel Gonçalves. Curso de direito constitucional. 29a ed., rev. e atual. São Paulo: Saraiva, 2002.

Direitos humanos fundamentais. 5a ed. rev. São Paulo: Saraiva, 2002.

FIANI, Ronaldo. Teoria dos Jogos: com aplicações em Economia, Administração e Ciências Sociais. $2^{\mathrm{a}}$ ed. rev. e atual. Rio de Janeiro: Elsevier, 2006.

FIGUEIREDO, Marcelo. Federalismo x Centralização. A eterna busca do equilíbrio - A tendência mundial de concentração de poderes na União. A questão dos governos locais. In: Interesse Público. Porto Alegre: Notadez, ano 9, nº 41, jan-fev de 2007, pp. 93-108.

FILGUEIRAS, Fernando. Corrupção, democracia e legitimidade. Belo Horizonte: Editora UFMG, 2008.

FONROUGE, Carlos M. Giuliani. Derecho Financiero. $2^{\mathrm{a}}$ ed. ampl. e atual. Buenos Aires: Depalma, 1970, v. 1.

FREILLE, Sebastian; HAQUE, M. Emranul; KNELLER, Richard. Decentralisation, Corruption and Economic Development. (16 mar 2007). Disponível em http://ssrn.com/abstract=985638, acessado em 16.07.2008.

GASPARINI, Carlos Eduardo; COSSIO, Fernando Andrés Blanco. Transferências intergovernamentais. In: MENDES, Marcos (org.). Gasto público eficiente: 91 
propostas para o desenvolvimento do Brasil. São Paulo: Instituto Braudel/Topbooks, 2006, pp. 175-201.

GIAMBIAGI, Fabiano; ALÉM, Ana Cláudia Duarte de. Finanças públicas. $2^{\mathrm{a}}$ ed. Rio de Janeiro: Elsevier, 2000.

GIANNETTI, Eduardo. Vícios privados, benefícios públicos?: a ética na riqueza das nações. São Paulo: Companhia das Letras, 1993.

GRIZIOTTI, Benvenuto. Princípios de ciencia de las finanzas. Tradução de Dino Jarach. $6^{\mathrm{a}}$ ed. italiana, acrescida e atualizada. Buenos Aires: Depalma, 1959.

GUEDES, Álvaro Martim e FONSECA, Francisco (orgs.). Controle social da administração pública: cenário, avanços e dilemas no Brasil. São Paulo: Cultura Acadêmica/Oficina Municipal; Rio de Janeiro: FGV, 2007.

GUEDES, Kelly Pereira; GASPARINI, Carlos Eduardo. Descentralização fiscal e tamanho do governo no Brasil. In: Economia Aplicada, Ribeirão Preto, v. 11, n. 2, abr-jun de 2007, pp. 303-323. Disponível em http://www.scielo.br/scielo.php?script=sci_arttext\&pid=S141380502007000200007\&lng=en\&nrm=iso, acessado em 25.11.2009.

HAAPARANTA, Pertti; JUURIKKALA, Tuuli. Bribes and Local Fiscal Autonomy in Rússia. (4 maio 2007). BOFIT Discussion Paper n. 12/2007. Disponível em: http://ssrn.com/abstract=1001424, acessado em 16.07.2008.

HABIB, Sérgio. Brasil: quinhentos anos de corrupção: enfoque sócio-histórico-jurídicopenal. Porto Alegre: Sérgio Antonio Fabris Editor, 1994.

HARTLE, D. G. The theory of 'rent-seeking': some reflections. In: The Canadian Journal of Economics/Revue canadienne d'Economique, v. 16, n 4, nov. 1983, Blackwell Publishing/Canadian Economics Association, pp. 539-554.

HEFFERNAN, William C.; KLEINIG, John. The corruptibility of corruption. In: HEFFERNAN, William C.; KLEINIG, John (org.). Private and Public Corruption. Oxford: Rowman \& Littlefield Publishers, Inc., 2004, pp. 3-22.

JELLINEK, Georg. Teoría general del Estado. Tradução de Fernando de Los Ríos. México: Fondo de Cultura Económica, 2000. Título original: Allgemeine Staatslehre. JÈZE, Gaston. Traité de science des finances: le budget. Paris: V. Giard \& E. Brière, 1910. 
JUSTEN FILHO, Marçal. Curso de direito administrativo. São Paulo: Saraiva, 2005.

KATZ, Daniel; KAHN, Robert L. Psicologia social das organizações. Tradução de Auriphebo Simões. 2a ed. São Paulo: Atlas, 1974. Título original: The Social Psychology of Organizations.

KETTERING, Sharon. The Historical Development of Political Clientelism. In: Journal of Interdisciplinary History, v. 18, $\mathrm{n}^{\circ} 3,1988$, pp. 419-447.

KRUEGER, Anne O. The Political Economy of the Rent-Seeking Society. In: The American Economic Review, v. 64, n 3, jun. 1974, pp. 291-303.

LACOMBE, Francisco José Masset. Dicionário de administração. São Paulo: Saraiva, 2004.

LEAL, Victor Nunes. Coronelismo, enxada e voto: o município e o regime representativo no Brasil. $3^{\text {a }}$ ed. Rio de Janeiro: Nova Fronteira, 1997.

LEMARCHAND, Rene; LEGG, Keith. Political clientelism and development: a preliminary analysis. In: Comparative Politics, v. 4, $\mathrm{n}^{\circ} 2$, jan. 1972, Ph. D. Program in Political Science of the City University of New York, pp. 149-178.

LIMONGI, Fernando. Presidencialismo e Governo de Coalizão. In: AVRITZER, Leonardo; ANASTASIA, Fátima (org.). Reforma política no Brasil. Belo Horizonte: Editora UFMG, 2006, pp. 237-257.

LOBO, Rogério Leite. Federalismo fiscal brasileiro: discriminação das rendas tributárias e centralidade normativa. Rio de Janeiro: Editora Lumen Juris, 2006.

LONGO, Carlos Alberto; TROSTER, Roberto Luis. Economia do setor público. São Paulo: Atlas, 1993.

M. MURPHY, Kevin; SHLEIFER, Andrei; VISHNY, Robert W. Why is rent-seeking so costly to growth? In: The American Economic Review, v. 83, $\mathrm{n}^{\circ} 2$, maio de 1993, American Economic Association, pp. 409-414.

MAIZ, Ramon. Jama, caleta y camello: la corrupcion como mecanismo de autorrefuerzo del clientelismo político. In: Revista Mexicana de Sociologia, v. 65, n 1, jan-mar de 2003, Universidad Nacional Autônoma de México, pp. 3-39.

MANDEVILLE, Bernard. La fabula de las abejas o los vicios privados hacen la prosperidad pública. Tradução de José Ferrater Mora. México: Fondo de Cultura 
Econômica, 1982. Título original: The Fable of the Bees: or Private Vices, Public Benefits.

MANFRONI, Carlos A. La Convención Interamericana contra la Corrupción: anotada y comentada. $2^{\mathrm{a}}$ ed. atual. Buenos Aires: Abeledo-Perrot, 2001.

MANUAL TÉCNICO DE ORÇAMENTO - MTO: Versão 2010. Brasília: Ministério do Planejamento, Orçamento e Gestão - Secretaria de Orçamento Federal, 2009; também disponível em https://www.portalsof.planejamento.gov.br/bib/MTO/MTO_2010_VF6.pdf, acessado em 26.12.2009.

MASTROPAOLO, Alfio. Clientelismo. In: BOBBIO, Norberto; MATTEUCCI, Nicola; PASQUINO, Gianfranco. Dicionário de política. $12^{\mathrm{a}}$ ed. Tradução de Carmen C. Varriale et al. Coord. da tradução: João Ferreira. Brasília: Editora Universidade de Brasília, 2002, v. 1, pp. 177-179.

MAURO, Paolo. Os efeitos da corrupção sobre crescimento, investimentos e gastos do governo: uma análise de países representativos. In: ELLIOTT, Kimberly Ann (org.). A corrupção e a economia global. Tradução de Marsel Nascimento Gonçalves de Souza. Brasília: Editora Universidade de Brasília, 2002, pp. 135-167. Título original: Corruption and the global economy.

MELlO, Celso Antônio Bandeira de. Curso de direito administrativo. $17^{\mathrm{a}}$ ed. rev. e atual. São Paulo: Malheiros, 2004.

MELLO, José Luiz de Anhaia. O Estado Federal e as suas novas perspectivas. São Paulo: Max Limonad, 1960.

MELLO, Oswaldo Aranha Bandeira de. Natureza jurídica do Estado Federal. São Paulo: Editora Revista dos Tribunais, 1937.

MENDES, Marcos. Capture of fiscal transfers: a study of Brazilian local governments. In: Economia Aplicada, Ribeirão Preto, v. 9, n. 3, jul-set. de 2005, pp. 427-444. Disponível em http://www.scielo.br/scielo.php?script=sci_arttext\&pid=S1413$80502005000300005 \& \operatorname{lng}=$ pt\&nrm=iso, acessado em 10.01.2010.

Federalismo fiscal. In: ARVATE, Paulo; BIDERMAN, Ciro (org.). Economia do setor público no Brasil. Rio de Janeiro: Elsevier, 2004, pp. 421-461. 
MENDONÇA, Erasto Fortes. Estado patrimonial e gestão democrática do ensino público no Brasil. In: Educação \& Sociedade. Campinas, v. 22, n. 75, ano XXII, ago. 2001, pp. 84-108, disponível em http://www.scielo.br/scielo.php?script=sci_arttext\&pid=S0101$73302001000200007 \& \operatorname{lng}=$ pt\&nrm=iso, acessado em 16.09.2009.

MIRANDA, Jorge. Teoria do Estado e da Constituição. Rio de Janeiro: Forense, 2005.

MONTAIGNE, Michel de. Ensaios. In: Os Pensadores. Tradução de Sérgio Milliet. São Paulo: Nova Cultural, 1996, v. 2. Título original: Essais.

MONTERO, Antonio Giménez. Federalismo fiscal: teoria y práctica. $2^{\text {a }}$ ed. Valencia: Tirant lo Blanch, 2003.

MONTESQUIEU (Charles-Louis de Secondant, Barão de La Brède e de Montesquieu). Do Espírito das Leis. (Coleção Os Pensadores). Trad. Editora Bertrand Brasil. Rio de Janeiro. São Paulo: Nova Cultural, 1997. Título original: De l’Esprit des lois, ou du rapport que les lois doivent avoir avec la constitution de chaque gouvernement, les mouers, le climat, la religion, le commerce, etc. $-1^{\text {a }}$ edição, 1748.

MOREIRA NETO, Diogo de Figueiredo. Curso de direito administrativo: parte introdutória, parte geral e parte especial. $14^{\mathrm{a}}$ ed. rev., ampl. e atual. Rio de Janeiro: Forense, 2005.

MUSGRAVE, Richard Abel. Teoria das finanças públicas: um estudo de economia governamental. Tradução de Auriphebo Berrance Simões. São Paulo: Atlas; Brasília: INL, 1973, v. 1. Título original: The theory of public finance: a study in public economy.

NALINI, José Renato. Ética geral e profissional. $4^{\mathrm{a}}$ ed. rev., atual. e ampl. São Paulo: Editora Revista dos Tribunais, 2004.

NASCIMENTO, Carlos Valder do. Arts. $1^{\circ}$ a 17. In: MARTINS, Ives Gandra da Silva; NASCIMENTO, Carlos Valder do. Comentários à Lei de Responsabilidade Fiscal. São Paulo: Saraiva, 2001, pp. 9-127.

NITTI, Francesco. Princípios da ciência das finanças. Tradução de C. Machado. Rio de Janeiro: Atena Editora, 1937, v. 2.

OATES, Wallace Eugene. An Essay on Fiscal Federalism. In: Journal of Economic Literature. Nashville: American Economic Association, set. 1999, v. 37, n 3, pp. 
1120-1149, disponível também em http://www.jstor.org/pss/2564874, acessado em 02.06.1999.

The role of intergovernmental grants in the U.S. economy with special attention to countercyclical policy. In: Studies in fiscal federalism. Hants: Edward Elgar, 1991, pp. 174-200.

The theory of public finance in a federal system. In: Studies in Fiscal Federalism. Hants: Edward Elgar, 1991, pp. 3-20.

OLIVEIRA, Regis Fernandes de. Curso de direito financeiro. São Paulo: Editora Revista dos Tribunais, 2006.

Dívida Pública e Operações de Crédito. In: Revista Tributária e de Finanças Públicas. São Paulo, ano 12, jul-ago de 2004, n. 57, Academia Brasileira de Direito Tributário (ABDT), Editora Revista dos Tribunais, pp. 201-220.

OLIVEIRA FILHO, João de. Instituição. In: SANTOS, J. M. de Carvalho. Repertório enciclopédico do direito brasileiro. Rio de Janeiro: Editor Borsoi, v. 27, pp. 241-243.

PASQUINO, Gianfranco. Corrupção. In: BOBBIO, Norberto; MATTEUCCI, Nicola; PASQUINO, Gianfranco. Dicionário de política. $12^{\mathrm{a}}$ ed. Tradução de Carmen C. Varriale et al. Coord. da tradução: João Ferreira. Brasília: Editora Universidade de Brasília, 2002, v. 1, pp. 291-293.

PAZZAGLINI FILHO, Marino; ROSA, Márcio Fernando Elias; FAZZIO JÚNIOR, Waldo. Aspectos jurídicos da defesa do patrimônio público. $4^{\mathrm{a}}$ ed. São Paulo: Atlas, 1999.

PENNOCK, J. Roland. The "pork barrel" and majority rule: a note. In: The Journal of Politics, Cambridge University Press/Southern Political Science Association, v. 32, $\mathrm{n}^{\circ} \quad 3, \quad$ ago. 1970, p. 709-716; também disponível em http://www.jstor.org/stable/2128838, acessado em 03.01.2010.

PEREIRA, Carlos; MUELLER, Bernardo. Comportamento estratégico em presidencialismo de coalizão: as relações entre Executivo e Legislativo na elaboração do orçamento brasileiro. In: Dados - Revista de Ciências Sociais. Rio de Janeiro, v. 45, $\quad \mathrm{n}^{\circ} \quad 2, \quad 2002$, (p. 265-301). Também disponível em http://www.scielo.br/scielo.php?script=sci_arttext\&pid=S0011$52582002000200004 \& \operatorname{lng}=\mathrm{en} \& \mathrm{nrm}=$ iso, acessado em 05.01.2010. 
PIANCASTELLI; Marcelo; BOUERI, Rogério; LIMA, Edilberto Pontes. Descentralização fiscal, harmonização tributária e relações intergovernamentais: como distintas federações reagem aos desafios da globalização. In: REZENDE, Fernando (coord.). Desafios do federalismo fiscal. Rio de Janeiro: Editora FGV, 2006, pp. 25-82.

PIANCASTELLI; Marcelo; PEROBELLI, Fernando. ICMS: evolução recente e guerra fiscal. Brasília, Ipea - Instituto de Pesquisa Econômica Aplicada, fev. 1996, texto para discussão $\quad$ n. 402. Também disponível em http://www.portalfederativo.gov.br/pub/Inicio/EstudosFederativos/td_0402.pdf, acessado em 23.11.2009.

PINDYCK, Robert S.; RUBINFELD, Daniel L. Microeconomia. Tradução de Eleutério Prado. $5^{\text {a }}$ ed. São Paulo: Prentice Hall, 2002. Título original: Microeconomics.

PINHEIRO, Armando Castelar; SADDI, Jairo. Direito, Economia e Mercados. Rio de Janeiro: Elsevier, 2005.

PORFÍRIO JÚNIOR, Nelson de Freitas. Federalismo, Tipos de Estado e Conceito de Estado Federal. In: CONTI, José Mauricio (org.). Federalismo fiscal. Barueri: Manole, 2004, pp. 1-13.

PRADO, Sérgio. Equalização e federalismo fiscal: uma análise comparada: Alemanha, Índia, Canadá, Austrália. Rio de Janeiro: Konrad-Adenauer-Stiftung, 2006.

PROCTER, Paul (edit.). Cambridge International Dictionary of English. New York: Cambridge University Press, 1995.

RAMOS, Dircêo Torrecillas. O federalismo assimétrico. São Paulo: Plêiade, 1998.

RENNÓ, Lucio R. Críticas ao Presidencialismo de Coalizão no Brasil: Processos Institucionalmente Constritos ou Individualmente Dirigidos? In: AVRITZER, Leonardo; ANASTASIA, Fátima (org.). Reforma política no Brasil. Belo Horizonte: Editora UFMG, 2006, pp. 259-271.

REZENDE, Fernando. Brasil: conflitos federativos e reforma tributária. In: REZENDE, Fernando (coord.). Desafios do federalismo fiscal. Rio de Janeiro: Editora FGV, 2006, pp. 83-114.

REZENDE, Fernando; AFONSO, José Roberto. A Federação Brasileira: Fatos, Desafios e Perspectivas. Jan. 2003, BNDES. Disponível em http://info.worldbank.org/etools/docs/library/229990/Rezende\%20e\%20Afonso.pdf, 
acessado

em

19.11.2009.

Também

disponível

em

http://www.bndes.gov.br/SiteBNDES/export/sites/default/bndes_pt/Galerias/Arquivo s/bf_bancos/e0002426.pdf, acessado em 19.11.2009.

RIBEIRO, José Joaquim Teixeira. Lições de finanças públicas. $5^{\mathrm{a}}$ ed. atual. Coimbra: Coimbra Editora, 1997.

RIBEIRO, Renato Janine. A República. $2^{\mathrm{a}}$ ed. São Paulo: Publifolha, 2008.

A Democracia. $3^{\text {a }}$ ed. São Paulo: Publifolha, 2008.

RODDEN, Jonathan. Federalismo e descentralização em perspectiva comparada: sobre significados e medidas. Tradução de Miriam Adelman e Marta Arretche. In: Revista de Sociologia e Política, jun. 2005, n. 24, Curitiba, pp. 9-27. Também disponível em http://www.scielo.br/scielo.php?pid=S0104-

44782005000100003\&script=sci_arttext\&tlng=, acessado em 17.07.2008.

ROSA JÚNIOR, Luiz Emygdio F. da. Manual de direito financeiro \& direito tributário. $16^{\mathrm{a}}$ ed. atual. Rio de Janeiro: Renovar, 2002.

ROSE-ACKERMAN, Susan. A economia política da corrupção. In: ELLIOTT, Kimberly Ann (org.). A corrupção e a economia global. Tradução de Marsel Nascimento Gonçalves de Souza. Brasília: Editora Universidade de Brasília, 2002, pp. 59-102. Título original: Corruption and the global economy.

ROSEN. Harvey S. Public Finance. $7^{\text {a }}$ ed. New York: McGraw-Hill/Irwin, 2005.

ROVERSI-MONACO, Fabio. Descentralização e centralização. In: BOBBIO, Norberto; MATTEUCCI, Nicola; PASQUINO, Gianfranco. Dicionário de política. $12^{\mathrm{a}}$ ed. Tradução de Carmen C. Varriale et al. Coord. da tradução: João Ferreira. Brasília: Editora Universidade de Brasília, 2002, v. 1, pp. 329-335.

SANCTIS, Frei Antonio de (org.). Encíclicas e documentos sociais: da "Rerum Novarum" à “Octogésima Adveniens”. São Paulo: LTR, 1972.

SANDRONI, Paulo. Dicionário de administração e finanças. São Paulo: Editora Best Seller, 2003.

Dicionário de Economia e Administração. In: Os Economistas. São Paulo: Nova Cultural, 1996. 
SANTOS, Fabiano. Governos de Coalizão no Sistema Presidencial: O caso do Brasil sob a Égide da Constituição de 1988. In: AVRITZER, Leonardo; ANASTASIA, Fátima (org.). Reforma política no Brasil. Belo Horizonte: Editora UFMG, 2006, pp. 221236.

SANTOS, Wanderley Guilherme dos. Democracia. In: AVRITZER, Leonardo; BIGNOTTO, Newton; GUIMARÃES, Juarez; STARLING, Heloisa Maria Murgel (org.). Corrupção: ensaios e críticas. Belo Horizonte: Editora UFMG, 2008, pp. 125130.

SATO, Motohiro. The Political Economy of Interregional Grants. In: BOADWAY, Robin; SHAH, Anwar (edit.). Intergovernmental fiscal transfers: principles and practice. Washington: The World Bank, 2007, pp. 173-201.

SCAFF, Fernando Facury. Como a sociedade financia o Estado para a implementação dos direitos humanos no Brasil. In: Interesse Público. Porto Alegre: Notadez, ano 8, $\mathrm{n}^{\circ}$ 39, set-out de 2006, pp. 187-211.

SCHWARTZMAN, Simon e SANTOS, Mario R. Empresários y politica en el proceso de industrializacion. Argentina, Brasil, Austrália. Tradução de Mario R. dos Santos. In: Desarrollo Económico, Instituto de Desarrollo Económico y Social, v. 13, n. 49, abrjun 1973, pp. 67-89.

SEYF, Ahmad. Corruption and development: a study of conflict. In: Development in Practice, v. 11, $\mathrm{n}^{\circ}$ 5, nov. 2001, Taylor \& Francis, Ltd., pp. 597-605.

SIEYES, Emmanuel. ¿Qué es el Tercer Estado?: Precedido de Ensayo sobre los privilegios. Tradução de Marta Lorente Sariñena e Lidia Vázquez Jiménez. Madrid: Alianza Editorial, 2008. Título original: Qu'est-ce que le Tiers-État? Essai sur les privilèges.

SILVA, José Afonso da. Comentário contextual à Constituição. São Paulo: Malheiros, 2005. Orçamento-programa no Brasil. São Paulo: Editora Revista dos Tribunais, 1973.

SILVA, Marcos Fernandes Gonçalves da. A economia política da corrupção no Brasil. São Paulo: SENAC São Paulo, 2001. 
Corrupção e produção de bens públicos. In: ARVATE, Paulo; BIDERMAN, Ciro (org.). Economia do setor público no Brasil. Rio de Janeiro: Elsevier, 2004, pp. 126135.

SILVA, Mauro Santos. Teoria do federalismo fiscal: notas sobre as contribuições de Oates, Musgrave, Shah e Ter-Minassian. In: Nova Economia. Belo Horizonte, jan-abr de 2005, pp. 117-137.

SINGER, Peter. Ética prática. Tradução de Jefferson Luiz Camargo. $3^{\text {a }}$ ed. São Paulo: Martins Fontes, 2002. Título original: Practical Ethics.

SOUZA, Celina. Federalismo e Conflitos Distributivos: Disputa dos Estados por Recursos Orçamentários Federais. In: Dados - Revista de Ciências Sociais. Rio de Janeiro, v. 46, $\mathrm{n}^{\circ}$ 2, 2003, pp. 345-384. Também disponível em http://www.scielo.br/pdf/dados/v46n2/a06v46n2.pdf, acessado em 02.12.2008.

Redemocratização, federalismo e gasto social no Brasil: tendências recentes. Petrópolis (RJ), 23-27 out. 1999, XXIV Encontro Anual da Associação Nacional de Pós-graduação em Ciências Sociais (ANPOCS). Disponível em http://info.worldbank.org/etools/docs/library/232522/SouzaRedemocratizacao.pdf, acessado em 26.11.2009.

STEIN, Robert M. e BICKERS, Kenneth N. Congressional Elections and the Pork Barrel. In: The Journal of Politics, Cambridge University Press/Southern Political Science Association, v. 56, $\mathrm{n}^{\circ}$ 2, mai. 1994, pp. 377-399. Também disponível em http://www.jstor.org/stable/2132144, acessado em 03.01.2010.

STEPAN, Alfred. Brazil's Decentralized Federalism: Bringing Government Closer to the Citizens? In: Daedalus, v. 129, n. 2, Brazil: The Burden of the past: The Promise of the Future, primavera-2000, The MIT Press on behalf of American Academy of Arts \& Sciences, pp. 145-169. Também disponível em http://www.jstor.org/stable/20027632, acessado em 26.11.2009.

Para uma nova análise comparativa do federalismo e da democracia: federações que restringem ou ampliam o poder do Demos. In: Dados - Revista de Ciências Sociais. Rio de Janeiro, v. 42, n. 2, 1999, pp. 593-634. Tradução de Vera Pereira. Título original: Toward a New Comparative Analysis of Democracy and Federalism: Demos Constraining and Demos Enabling Federations. Disponível em 
http://www.scielo.br/scielo.php?script=sci_arttext\&pid=S0011-

$52581999000200001 \& \operatorname{lng}=$ pt\&nrm=iso, acessado em 26.11.2009.

TER-MINASSIAN, Teresa. Brazil. In: TER-MINASSIAN, Teresa (edit.). Fiscal federalism in theory and practice. Washington: International Monetary Fund, 1997, p. $438-456$.

TIEBOUT, Charles M. A Pure Theory of Local Expenditures. In: The Journal of Political Economy. Chicago: University of Chicago, out. 1956, pp. 416-424, v. 64, n 5, também disponível em http://www.journals.uchicago.edu/doi/abs/10.1086/257839, acessado em 02.06.2009.

TOCQUEVILLE, Alexis. A democracia na América. Tradução de J. A. G. Albuquerque. In: Os Pensadores. São Paulo: Abril Cultural, 1979.

TOCQUEVILlE, Alexis. Democracia na América. Tradução de João Miguel Pinto de Albuquerque. São Paulo: Companhia Editora Nacional/Editora da Universidade de São Paulo, 1969. Título original: Democracy in America.

TORRES, Ricardo Lobo. Curso de direito financeiro e tributário. $11^{\mathrm{a}}$ ed. atual. Rio de Janeiro: Renovar, 2004.

Tratado de direito constitucional financeiro e tributário: os direitos humanos e a tributação: imunidades e isonomia. $3^{\text {a }}$ ed., rev. e atual. Rio de Janeiro: Renovar, 2005, v. 3 .

Tratado de direito constitucional financeiro e tributário: o orçamento na Constituição. $2^{\mathrm{a}}$ ed., rev. e atual. Rio de Janeiro: Renovar, 2000, v. 5.

TRANSPARENCY INTERNACIONAL, Departamento de Investigación y Políticas, "Informe sobre el Barômetro Global de la Corrupción de Transparency Internacional 2007”, Berlim, 6 dez. 2007. Disponível em www.transparency.org/content/download/27458/413669/file/GCB_2007_report_esp _02-12-2007.pdf, acessado em 28.11.2008.

TREISMAN, Daniel. The Causes of Corruption: A Cross-National Study. In: Journal of Public Economics, Elsevier Science S.A., 2000, v. 76, n. 3, pp. 399-457.

TREVISAN, Antoninho Marmo; CHIZZOTTI, Antonio; IANHEZ, João Alberto; CHIZZOTTI, José Chizzotti; VERILLO, Josmar. O combate à corrupção nas prefeituras do Brasil. $4^{\mathrm{a}}$ ed. Cotia: Ateliê Editorial, 2003. 
TRIBUNAL DE CONTAS DA UNIÃO. Convênios e outros repasses. 2. ed., Brasília: Secretaria-Geral de Controle Externo, 2008.

TULLOCK, Gordon. The Welfare Costs of Tariffs, Monopolies, and Theft. In: Western Economic Journal, Oxford, v. 5, 1967, pp. 224-232.

URQUIZA, José Manuel. Corrupción municipal: por qué se produce y cómo evitarla. Córdoba: Almuzara, 2005.

VARSANO, Ricardo. A guerra fiscal do ICMS: quem ganha e quem perde. Rio de Janeiro, 1998, Ipea - Instituto de Pesquisa Econômica Aplicada, jun. 1997, texto para discussão $\quad$ n. $500, \quad$ p. 5 . Também disponível em http://www.portalfederativo.gov.br/pub/Inicio/EstudosFederativos/td_0500.pdf, acessado em 23.11.2009.

VAZ, Henrique Cláudio de Lima. Ética e Direito. São Paulo: Landy Editora - Edições Loyola, 2002.

WEBER, Max. Economia e sociedade: fundamentos da sociologia compreensiva. Tradução de Regis Barbosa e Karen Elsabe Barbosa. 4ª ed. Brasília - São Paulo: Editora Universidade de Brasília - Imprensa Oficial do Estado de São Paulo, 1999, v. 1. Título original: Wirtschaft und Gesellschaft: Grundriss der verstehenden Soziologie.

ZIPPELIUS, Reinhold. Teoria geral do Estado. $3^{\mathrm{a}}$ ed. Tradução de Karin Praefke-Aires Coutinho. Lisboa: Fundação Calouste Gulbenkian, 1997. Título original: Allgemeine Staatslehre.

“A quem serve a guerra fiscal?”. O Estado de São Paulo, 12/03/2001, p. A-2.

"Aliados recebem mais transferências: capitais governadas por aliados de governadores recebem mais repasses voluntários". Jornal Valor Econômico (Cristiane Agostine e Marta Watanabe), 24/03/2008, p. A-8.

“Aprovado Orçamento de R\$ 1,86 trilhão em 2010”. Jornal do Senado, ano XV, n 3.163 , Brasília, 23/12/2009, p. 2.

"Em vídeo, aliado de Arruda guarda dinheiro nas meias". Folha de São Paulo, 30/11/2009, p. A-4. 
"Em vídeo, governador do DF recebe pacote de dinheiro". Folha de São Paulo, 29/11/2009, p. A-4.

"Esquema começou na campanha e deu origem a "mensalão"”. Folha de São Paulo, 30/11/2009, p. A-7.

"PF diz que Arruda mandou dar R 400 mil a deputados". Folha de São Paulo, 28/11/2009, p. A-4. 